Szegedi Tudományegyetem

Természettudományi és Informatikai Kar

Földtudományok Doktori Iskola

Gazdaság- és Társadalomföldrajz Tanszék

\title{
A MAGYAR ORSZÁGGYÜLÉSI VÁLASZTÁSI RENDSZER FÖLDRAJZI TORZULÁSAINAK VIZSGÁLATA
}

\author{
Doktori (PhD) értekezés
}

Vida György

Témavezető

Prof. Dr. Kovács Zoltán

Akadémikus, tanszékvezető egyetemi tanár

Szeged

2020 


\section{Tartalomjegyzék}

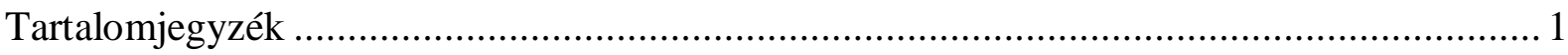

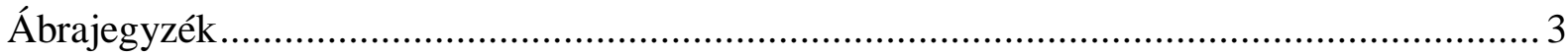

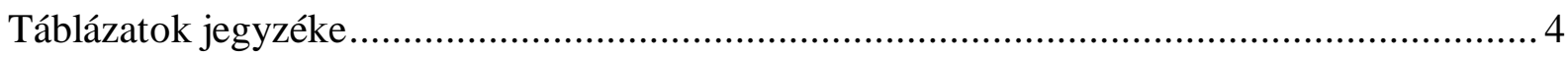

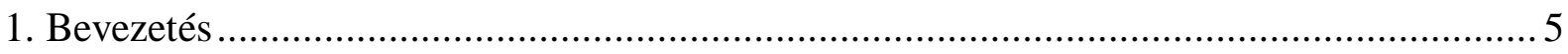

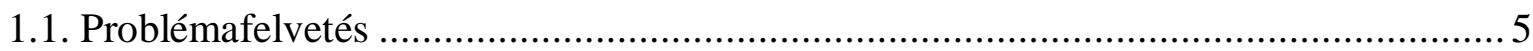

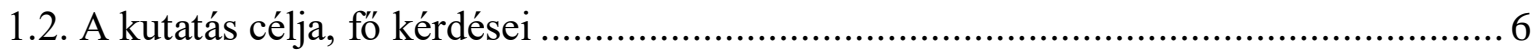

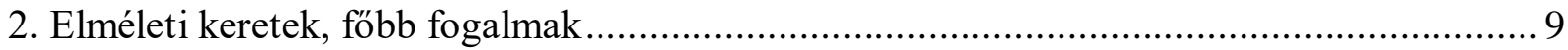

2.1 A választási földrajz tudományos felemelkedése, elméleti válsága és megújulási kísérletei

2.2 Választási rendszerek fôbb típusai és jellemzői ..................................................... 14

2.3 A rendszerváltozás utáni magyar választási törvények föbb tulajdonságai és földrajzi

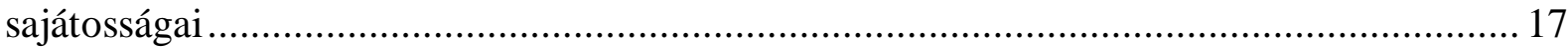

2.4. Választási rendszerek földrajzi torzulásai és azok nemzetközi értelmezései ............... 22

2.4.1. Malapportionment és reactive malapportionment ……………............................. 26

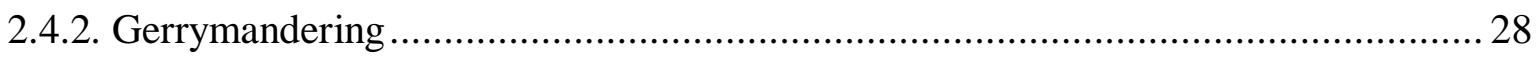

2.5. A választókerületek kialakításának kritikai és posztstrukturalista megközelítései .......30

2.6. Választási földrajzi torzulások posztszocialista és magyarországi megközelítésben... 33

2.7. A választási földrajzi torzulások hatótényezöinek dinamikus elméleti modellje ......... 37

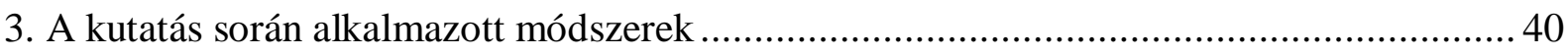

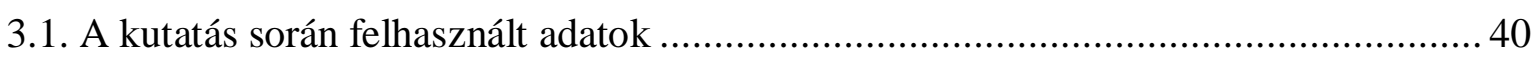

3.2. A kutatás során használt matematikai és statisztikai módszerek .................................. 41

4. A magyar választási rendszer aránytalanságai és a politikai pártok támogatottságának

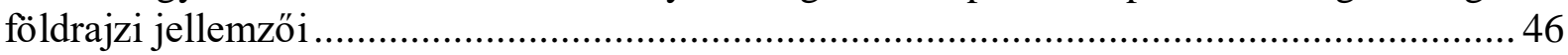

4.1 A magyar választási rendszer általános aránytalanságai nemzetközi összehasonlításban 46

4.2 A politikai pártok szavazóbázisának változása 2002 és 2018 között az átalakuló

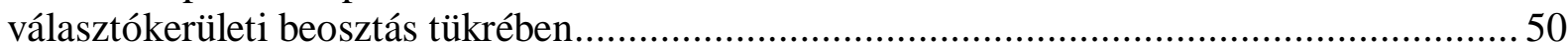

4.2.1 A 2002-es országgyülési választások földrajzi jellemzői ........................................ 51

4.2.2. A 2006-os országgyülési választások földrajzi jellemzői........................................... 53

4.2.3. A 2010-es országgyülési választások földrajzi jellemzői .........................................5 55

4.2.4. A 2014-es országgyülési választások földrajzi jellemzői .........................................58

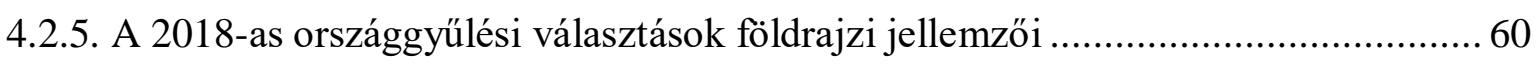

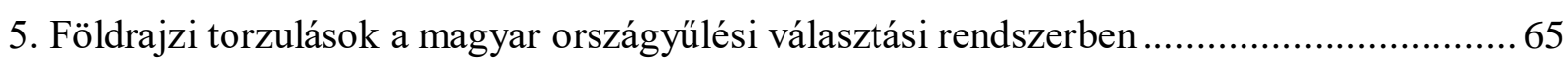

5.1. Malapportionment a magyar országgyülési választási rendszerben................................ 65

5.2. Reactive malapportionment a magyar országyülési választási rendszerben................. 72

5.3 Gerrymandering a magyar országyülési választási rendszerben.................................... 81 
Összegzés 95

Summary 101

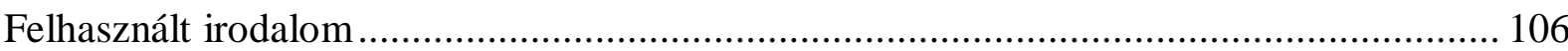

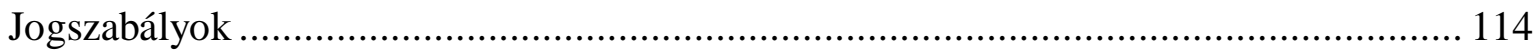

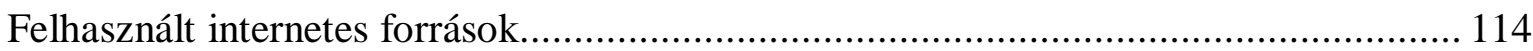

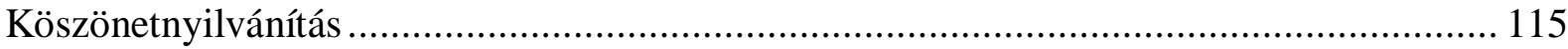

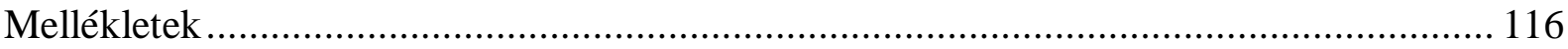




\section{Ábrajegyzék}

1. ábra: Az országgyülési egyéni választókerületek beosztása 1990 és 2010 között .............. 18

2. ábra: Az országgyülési egyéni választókerületek beosztása 2011 után ........................... 21

3. ábra: A választási rendszerekre ható földrajzi hatótényezők elméleti modelljének magyarországi adaptációja 38

4. ábra: A posztszocialista országok győztes pártjainak mandátum és szavazatarányának dinamikus változása a legutóbbi hét országgyülési választás (1995-2018) eredményei alapján

5. ábra: A 176 választókerület politikai klaszterei és klaszterközéppontjai 2002-ben ............ 52

6. ábra: A 176 választókerület politikai klaszterei és klaszterközéppontjai 2006-ban ............ 54

7. ábra: A 176 választókerület politikai klaszterei és klaszterközéppontjai 2010-ben ............ 56

8. ábra: A 106 választókerület politikai klaszterei és klaszterközéppontjai 2014-ben ............ 59

9. ábra: A 106 választókerület politikai klaszterei és klaszterközéppontjai 2018-ben ............ 61

10. ábra: A felnőtt lakosságszám 1990 és 2011 közötti változásának települési szintű Getis-Ord féle lokális területi autokorrelációja. 66

11. ábra A választásra jogosultak szélsőértékei az egyéni választókerületekben 1990-2018 között.

12. ábra A választásra jogosultak százalékos aránya az országos átlaghoz viszonyítva a 176 egyéni választókerületben 2010-ben.

13. ábra A választásra jogosultak százalékos aránya az országos átlaghoz viszonyítva a 106 egyéni választókerületben a 2011-es népszámlálási adatok alapján

14. ábra: A felnőtt lakosságszám 2012 és 2018 közötti változásának települési szintü Getis-Ord féle lokális területi autokorrelációja. 70

15. ábra: A választásra jogosultak százalékos aránya az országos átlaghoz viszonyítva a 106 egyéni választókerületben a 2018-as országgyülési választások alapján.

16. ábra: A 2002-és 2018 közötti országgyülési választások átlagos részvételének települési szintü Getis-Ord féle lokális területi autokorrelációja 73

17. ábra A regionális versenyképesség főkomponens és a választási részvétel Pearson korrelációi 2010 és 2018 között. .74

18. ábra: Pearson korrelációs összefüggések iránya a korábbi választókerületi rendszerben a pártok listás eredményei és a választásra jogosultak, választáson résztvevők, valamint a parlamentbe bejutott pártokra leadott listás voksok alapján 76

19. ábra: Pearson korrelációs összefüggések iránya a jelenlegi választókerületi rendszerben a pártok listás eredményei és a választásra jogosultak, választáson résztvevők, valamint a parlamentbe bejutott pártokra leadott listás voksok alapján 78

20. ábra: A pártlistás eredmények és a strukturális mutatók közötti korrelációk változásának összetett pókháló diagramja 88

21. ábra: A Fidesz-KDNP listás szavazatarányainak települési szintű Local Moran-féle autokorrelációja a 2010 és 2018-as országgyülési választások átlaga alapján. 90

22. ábra: Az MSZP-Együtt-DK-PM-MLP összevont listás szavazatarányainak települési szintü Local Moran-féle autokorrelációja a 2010 és 2018-as országgyülési választások átlaga alapján 
23. ábra: A Jobbik listás szavazatarányainak települési szintü Local Moran-féle autokorrelációja a 2010 és 2018-as országgyülési választások átlaga alapján.

24. ábra: Az LMP listás szavazatarányainak települési szintű Local Moran-féle autokorrelációja a 2010 és 2018-as országgyülési választások átlaga alapján.

\section{Táblázatok jegyzéke}

1. táblázat: A választási rendszerek főbb típusai és általános jellemzőik 17

2. táblázat: A rendszerváltozás utáni magyar választási rendszerek főbb jellemzői 20

3. táblázat: A földrajzi torzulásokat meghatározó résztényezők elméleti koncepciója . 24

4. táblázat: Néhány posztszocialista ország választási rendszerének főbb tulajdonságai 2017ben.

5. táblázat: A posztszocialista országok győztes pártjainak mandátum- és szavazatarány értékei a legutóbbi hét országgyülési választás (1995-2018) eredményei alapján

6. táblázat: A magyar választási rendszer általános aránytalanságai a vizsgált mutatók alapján 2002 és 2018 között

7. táblázat: Magyarország 2002-es választási földrajzi klaszterei a középpontokkal..............52

8. táblázat: Magyarország 2006-os választási földrajzi klaszterei a középpontokkal ............. 54

9. táblázat: Magyarország 2010-es választási földrajzi klaszterei a középpontokkal..............57

10. táblázat: Magyarország 2014-es választási földrajzi klaszterei a középpontokkal............ 59

11. táblázat: Magyarország 2018-as választási földrajzi klaszterei a középpontokkal............ 62

12. táblázat: A 2002-es, 2006-os és 2010-es pártlistás eredmények, a területi aránytalanság és reactive malapportionment tényezöi közötti Pearson, valamint Spearman $\left({ }^{*}\right.$-al jelölve a táblázatban) korrelációs értékek 77

13. táblázat A 2014-es, a 2018-as pártlistás eredmények, a területi aránytalanság és reactive malapportionment tényezői közötti Pearson, valamint Spearman (*-al jelölve a táblázatban) korrelációs értékek

14. táblázat: A parlamentbe bejutott pártok listáinak Variációs együtthatói, HerfindahlHirschman és Hoover indexei 2002 és 2010 között 82

15. táblázat A parlamentbe bejutott pártok listáinak választókerületi és települési szintű Giniindexei 2002 és 2010 között 84

16. táblázat: A parlamentbe bejutott pártok listáinak Variációs együtthatói, HerfindahlHirschman és Hoover indexei 2014 és 2018 között 85

17. táblázat A parlamentbe bejutott pártok listáinak választókerületi és települési szintü Giniindexei 2014 és 2018 között. 


\section{Bevezetés}

\subsection{Problémafelvetés}

A földrajz kitüntetett szerepet játszik azokban a demokráciákban, ahol a választások során a szavazatokat valamilyen földrajzi keretben alakítják át mandátumokká, ami főként a többségi és vegyes választási rendszerekre jellemző. 1990 óta nincs ez másként Magyarországon sem. Mivel a rendszerváltozás során a magyar társadalom is visszatért a képviseleti demokráciák modelljéhez, ezért újból vizsgálhatóvá váltak a választási rendszer mandátumkiosztásának földrajzi hatótényezői. 1990-ben az egyéni választókerületek határait nagyjából úgy húzták meg, hogy a választópolgárok száma mindegyikben megközelítőleg azonos legyen. Viszont már ekkor is jelentkeztek nagy egyenlötlenségek a választókerületek között, amelyre több földrajzos szerző is rámutatott (pl. HEGEDÜs G. 2007a, NAGY, G. 2007). Ekkor azonban még nem beszélhettünk tudatosan létrehozott választókerületi manipulációról, hiszen az előtte lévő közel fél évszázadban nem élhettek a választópolgárok demokratikus jogaikkal, így nem lehetett előre pontosan meghatározni az egyes pártok térbeli beágyazottságát és a jövőbeli eredményeket.

A rendszerváltozás azonban a politikai változás mellett jelentős demográfiai, gazdasági és társadalmi átalakulásokat is hozott Magyarországon. Az átmenet társadalomföldrajzi szempontból is növekvő területi egyenlőtlenségeket okozott, ami idővel a népesség belső migrációjában is megmutatkozott. Ebből adódóan az 1990 utáni időszakban a lakosság és a választópolgárok száma sok helyen jelentősen változott, ami tovább növelte az egyenlőtlenséget. Így egyre időszerübbé vált a választókerületi határok átrajzolása.

Ebből adódóan a téma aktualitását az adja, hogy a 2000-res évek eleje óta egyre többen megkérdőjelezték a rendszerváltozáskor (1989. évi XXXIV.tv., 2/1990. I.11. Minisztertanácsi Rendelet) létrehozott országgyülési választási rendszer igazságosságát. Többek között az Alkotmánybíróság is vizsgálta a választókerületek méretbeli eltéréseit, és azt alkotmányellenesnek nyilvánította, illetve módosításokra kérte fel az akkori döntéshozókat (22/2005. VI.17. Alkotmánybírósági határozat). Megállapítható, hogy a 2000-es években több sikertelen próbálkozás történt a rendszer megreformálására, majd a 2010-ben kétharmados többséggel kormányra kerülő Fidesz-KDNP koalíció jelentősen megváltoztatta a választások keretfeltételeit.

Az országgyülési képviselők választásáról szóló új törvény 2011-ben (2011. évi CCIII. tv.), a választási eljárási törvény pedig 2013-ban (2013. évi XXXVI. tv.) lépett hatályba. Az új feltételek jelentősen átírták a választások kereteit, hiszen a parlamenti képviselök számát 386ról 199-re, és az egyéni választókerületek számát 176-ról 106-ra csökkentették, új határokkal. Ennek eredményeként megváltozott a listás és többségi (választókerületi) helyek aránya is és a korábbi kétfordulós választásokat egyfordulósra módosították, így elég volt relatív többséget szerezni az egyéni választókerületekben. A kutatási témakörhöz kapcsolható további fontos részleteket a disszertáció elméleti részében bővebben is rendszerezem. $\mathrm{Az}$ előző keretfeltételekkel hat, míg az új rendszerben két országgyülési választást bonyolítottak le, amiből adódik, hogy lehetséges a régi és az új felosztás földrajzi hatásainak időbeli összehasonlítását elvégezni.

Mivel a választókerületek beosztásának mikéntje jelentős hatással lehet az eredményekre (MARTIS, K. C. 2008), ezért a választási rendszerek térbeli hatásainak elemzése és a különböző felosztások elméleti és gyakorlati kérdései (MORILL, R. L. 1973) a politikai földrajz egyik fajsúlyos témaköre (LOW, M. 2005). Nemzetközi szinten a választási rendszerek aránytalanságainak és a belölük fakadó földrajzi torzulások - például a területi eltérések és a választókerületek manipulatív lehatárolása - meghatározásának és mérési módszertanának 
széles körü, folyamatosan bővülő szakirodalma van (HuNG, Y.C. - CHEN, L. Y. 2019, GILMAN, R. 2002, JOHNSTON, R. 2002a, b, WEBSTER, G. R. 2013a,b).

A vizsgálandó témakör időszerüségéből és nemzetközi elméleti megalapozottságából adódóan aktuálissá vált Magyarország választási rendszerének egyenlőtlen politikai reprezentációt létrehozó térbeli tényezőinek feltárása és átfogó földrajzi elemzése is. Az 1990es évek pártpolitikai fejlődését és átrendeződését követően a választókerületi beosztás méretbeli eltérései különösen a 2002-es választásoktól számítottak relevánsnak, hiszen erre az időszakra stabilizálódott az akkori kétpólusú (BöHM A. 2003, FOWLER, B 2003, 2007, RÁCZ, B. 2003) pártstruktúra és a mandátumok kiosztásában ez is jelentős szereppel bírt. Az említett időszak óta Magyarország öt parlamenti választást bonyolított le, amiből három az előző, míg kettő az új keretfelételek szerint zajlott. Így kézenfekvővé vált, hogy a 2002-es, a 2006-os, a 2010-es, a 2014-es és a 2018-as országgyülési választások összehasonlító vizsgálata új tudományos és gyakorlati hozadékkal járhat, ha világossá válik az, hogy a régi és új beosztás pontosan hogyan formálta Magyarországon a pártok szavazatait mandátumokká.

\subsection{A kutatás célja, fö kérdései}

A doktori kutatás fö célja, hogy a magyar országgyülési választási rendszer térbeli sajátosságait időben vizsgálja, illetve az egyenlőtlen politikai reprezentációt okozó földrajzi hatásokat kimutassa 2002 és 2018 között. Azonban a kutatási kérdések meghatározása elött szükséges az angolszász szakirodalomban használt fogalmak tisztázása már az elméleti részt megelőzően, hiszen ezeket a kifejezéseket még nem használta széles körben a hazai szakirodalom szerint ez segítheti a dolgozat értelmezését. A disszertáció központi fogalma a földrajzi torzulás. Földrajzi torzulás alatt értek mindazon választással kapcsolatos térbeli tényezőt, ami a mandátumkiosztásban egyenlőtlen politikai reprezentációt hozhat létre. Ezen belül kifejezetten három résztényezőt érdemes kiemelni: Malapportionment, Reactive malapportionment és Gerrymandering.

Malapportionment alatt ebben az esetben a választókerületek között a választásra jogosultak számának és arányának különbségeit és egyenlőtlenségeit értem. Hogyha a választókerületek eltérő számú választópolgárral rendelkeznek az hat a választási rendszer mandátumkiosztási gyakorlatára, igazságtalan, így ez egy részeleme a földrajzi torzulásnak. Fontos megjegyezni, hogy az angolszász szakzsargon kiváltására tett kísérletként a fogalom magyar szinonimájaként a területi aránytalanságot fogom használni akkor is, ha ez nem is minden esetben fedi teljesen az eredeti kifejezést.

Emellett szükséges az angolszász szakirodalomban használt reactive malapportionment fogalmát is meghatározni. Reactive malapportionment alatt a kutatásom során a választásra jogosultak eltéréseit a voksolás napján módosító főbb tényezőket értem. Ez két dolog, az egyik a választási részvétel hatása, valamint a másik a parlamentbe bejutott listás voksok egyenlőtlenségei a térben. A mandátumkiosztás ezen szavazatokból képződik, nem pedig a sima választásra jogosultak egyenlőtlenségeiböl, így súlyozni kell az adatokat. Tehát a pontosabb elemzésnél ki kell venni a távolmaradókat és az egyáltalán nem hasznosult voksokat is, hogy megkapjuk mekkora a reactive malapportionment a választási rendszerben.

Véleményem szerint a külföldi szó magyarosítását egyszerűen nem lehet úgy megoldani, hogy az megfelelően kifejezze az eredeti jelentését és ne egy magyarázó mondattá bővüljön. Az iménti bonyolultság miatt tudomásom szerint a hazai tudományos közélet a témakör körülírása mellett (HAJDÚ Z. 2006) még nem tett rá kísérletet, hogy rövid és frappáns magyar szóval fejezze ki ezt a fogalmat. Esetemben a reactive malapportionment szakzsargon kiváltására olyan módon teszek kísérletet, hogy az eredmények bemutatásánál a szó helyett „a 
területi aránytalanságot súlyozó tényezőket" (választási részvétel, parlamentbe bejutott pártokra leadott listás voksok) igyekszem használni.

Végezetül gerrymandering alatt a választókerületek olyan eredményorientált átszabását értem, ami jelen esetünkben bármilyen módon helyzetbe hoz, vagy hozhat politikai pártokat. Ez esetünkben a pártok támogatottságának különböző koncentrációját vagy dekoncentrációját jelenti a vizsgált időszakban. Ebből következtethetünk a kevert, esetleg homogén térfelosztásra. A gerrymandering esetében nem fogok magyar fogalmat meghatározni, hiszen megítélésem szerint a szó már beépült a hazai tudományos közbeszédbe hasonló módon (CZENE-Jó M. 2019, HAJDÚ Z. 2006), mint például a dzsentrifikáció (BERÉNYI B. E. 2016). Fontos megállapítani, hogy a magyar választási rendszer részletes bemutatása mellett a disszertáció elméleti részében bővebben kifejtem az imént meghatározott fogalmakat és ennek elméleti kereteit, továbbá a szakirodalmi előzményeket feldolgozva megfogalmaztam egy modellt, ami feltárta a tényezők közötti összefüggéseket és az ezekre ható háttérfolyamatokat is.

A téma indokoltsága, a problémafelvezetés és a fogalmak alapvető tisztázása alapján a dolgozatban arra a fö kérdésre kerestem a választ, hogy milyen földrajzi torzulások jellemezték a magyar választási rendszert 2002 és 2018 között? Ezen fö kutatási kérdés megválaszolásához több részkérdésen keresztül jutottam el. Így a disszertációban több alkérdést is megfogalmaztam, miszerint:

1. Milyen elméleti összefüggések vannak a malapportionment, a gerrymandering és a reactive malapportionment között?

2. 2002 után választókerületi szinten hogyan alakult a parlamentbe bejutott pártok választási földrajzi térszerkezete?

3. Az ezredfordulót követően a magyar választókerületi lehatárolásokban milyen mértékü volt a malapportionment?

4. Hogyan módosították a malapportionment hatótényezőjét a választási részvétel és a mandátumszámításba be nem kerülő voksok változó területi különbségei?

5. Hogyan alakult az ezredforduló után a magyar választókerületi beosztásokban a gerrymandering?

Az imént felvázolt kutatási kérdések megválaszolásával szándékozom a doktori kutatás fó célját elérni, 2002 és 2018 között a magyar országgyülési választási rendszerben az egyenlőtlen politikai reprezentációt okozó földrajzi torzulásokat kimutatni. Mindemellett elméleti és módszertani kutatásaim alapján szeretnék szakmai javaslatokat is megfogalmazni, amivel egyrészt rendszerezem azokat a hatótényezőket, amiket figyelembe kell venni a tervezésnél, másrészt leírom azokat a folyamatokat, amivel a jövőben egy időtállóbb, kiegyensúlyozottabb és stabilabb választókerületi beosztást lehet megalkotni. 
A doktori értekezés a bevezetést követően négy fö szerkezeti egységre és több alfejezetre tagolódik. Az első nagy fejezetben az elméleti kereteket és föként az angolszász szakirodalomból átvett értelmezéseket fejtem ki. Ennek első lépése a föbb nemzetközi választási rendszerek bemutatása, ezek előnyeinek és hátrányainak kidomborítása, valamint a rendszerváltozást követő magyar eljárás részletes feltárása. A hazai választási rendszer kifejtését követően a nemzetközi szakirodalom alapján a gerrymandering, a malapportionment és a reactive malapportionment pontos fogalmát, elméleti hátterét ismertetem, kiemelve a legfontosabb választási földrajzi megközelítések erősségeit és hiányosságait. Az alapfogalmak meghatározását követően még az elméleti részben a választókerületek kialakításának kritikai és posztstrukturalista megközelítéseit, és a posztszocialista sajátosságokat ismertetem. $\mathrm{Az}$ elméleti rész végén mutatom be a szakirodalmak alapján általam megfogalmazott és létrehozott új modellt, ami az első kutatási részkérésemre válaszol és a kutatás értelmezési keretét adja.

A doktori dolgozat második nagy fejezetében az elméleti keretek meghatározását követően a módszertan részletes kifejtése és a kutatás operacionalizálása következik. A választási adatok legyüjtésének és feldolgozásának folyamatát vázolom fel, a doktori kutatás módszertanának részletes bemutatásával együtt.

A disszertáció harmadik fejezetében - nemzetközi összevetést követően - a magyar választási rendszer általános (pl. mandátum kiosztási módszere, győzteskompenzáció stb.) aránytalanságait ismertetem, majd a parlamenti pártok térbeli beágyazottságának kimutatása következik. A tényezők közötti összefüggések miatt a politikai pártok szavazóbázisának térbeli eloszlását klaszterelemzéssel vizsgálom rávilágítva az időben megváltozott térfelosztás szerepére is.

A doktori értekezés negyedik fejezetében a földrajzi torzulások tényezőit egyenként elemzem, és egyrészt a malapportionment tényező kimutatásában a mögöttes demográfiai hatásokat is ismertetem, másrészt a következő alfejezetben a reactive malapportionment ( $\mathrm{pl}$. részvétel és mandátumkiosztásba nem kerülő voksok szerepe) egyenlőtlenséget módosító tényezőit vizsgálom 2002 és 2018 között. Végül a fejezet zárásaként a magyar választási rendszerben megtalálható gerrymandering 2002 és 2018 közötti összehasonlító geográfiai elemzését végzem el.

A doktori disszertáció a kutatási kérdések tételes megválaszolásával és a legfóbb tudományos megállapítások összegzésével zárul. A kutatási eredmények remélhetőleg felhívják a hazai döntéshozók figyelmét a választókerületek igazságosabb kialakításának fontosságára. A bemutatásra kerülő eredmények emellett hozzájárulhatnak a minél több társadalmi és térbeli tényezőt figyelembe vevő választókerületi lehatárolás kidolgozásához és a térfelosztás időközönként történő (pl. népszámlálásokat követő) sikeres felülvizsgálatához. 


\section{Elméleti keretek, föbb fogalmak}

„A demokráciának valami többnek kéne lennie, mint amikor két farkas és egy bárány szavaznak, hogy mi legyen a vacsora.” James Bovard (amerikai író, egyetemi tanár)

Doktori értekezésemben szükséges bizonyos elméleti és módszertani kérdések felvázolása, hiszen a kutatás során használt paradigmákat döntően nemzetközi, főként angolszász szakirodalmakból vettem. Mivel a hazai választási földrajzban különbözö jelentéstartalommal meghonosodott elméletek és kifejezések találhatóak, emiatt úgy vélem, hogy pontosan meg kell határoznom, hogy mit is értek a választási rendszer aránytalansága, földrajzi torzulás (electoral bias), gerrymandering, malapportionment, reactive malapportionment fogalmak alatt, valamint ezek tágabb elméleti beágyazottságát is szükséges kifejteni.

Ebből adódóan a következő fejezetben elsőként a nemzetközi és hazai választási földrajz fejlődésének főbb elméleti kérdéseit ismertetem, és ebben elhelyezem a választási rendszerek térbeli kutatásának főbb irányait. Ezután választási rendszerek főbb típusait és általános aránytalanságaikat mutatom be. Ezt követően a rendszerváltozást követő magyar választási rendszer főbb jellemzőit és változásait írom le. Ezt követően bemutatom a térfolyamatok szerepét a választási rendszerekben, így az egyenlőtlen politikai reprezentációt létrehozó földrajzi fogalmakat, az elméleti modelleket és ezek elemzésének módszertani dilemmáit. Mindemellett egy általam megalkotott elméleti modellben szintetizálom a választási rendszerek földrajzi torzulásainak hatótényezőit és a köztük lévő dinamikus kapcsolatokat.

\subsection{A választási földrajz tudományos felemelkedése, elméleti válsága és megújulási kísérletei}

A választási rendszerek elemzésével, a választókerületek kialakításának, igazságosságának vizsgálatával sok tudományterület foglalkozik, de a térbeliség összetett elemzése kifejezetten a földrajz vizsgálati körébe tartozik. Ezért fontosnak tartom az értekezésemben a tágabb választási földrajzi elméleti keretek és koncepciók ismertetését a nemzetközi és hazai szakirodalmak alapján.

A választási földrajz a politikai geográfia egy viszonylag fiatal szakterülete, amelynek létrejöttét hosszú folyamat előzte meg (GLASSNER, M. I. 1996, HAJdú Z. 2006, PATTIE, C. JOHNSTON, R. 2009). A választásokkal is foglalkozó angolszász politikai földrajz kialakulását a 19. század végére és a 20. század elejére tehetjük. A választási földrajz konkrét kialakulása viszont a francia iskola, azon belül is SIEGFRIED (1913) nevéhez kötődik, aki NyugatFranciaországot vizsgálta választási földrajzi szempontból, és azt állapította meg, hogy a választások eredményei adott régiókban állandóságot mutatnak (MEZÖ F. 2003). A francia iskola mellett kiemelkedett az angolszász választási földrajzban KREHBIEL (1916) munkássága, aki az angol voksolási mintázatokat vizsgálta társadalmi és környezeti szempontból, valamint SAUER (1918) munkássága, aki úttörőként a térbeliség és a választási manipuláció, vagyis a gerrymandering összefüggéseit elemezte (HAJDÚ Z. 2006). Ezek a tanulmányok lettek az alapjai annak a választási földrajznak, ami részletesen elemezte a voksolások eredményeit természeti és társadalmi összefüggéseket keresve (HuBAi L. 2004, PAINTER, J. - JEFFREY, A. 2009).

Megállapítható, hogy míg a választási földrajz hajnalán a környezeti determinizmus volt a meghatározó a kutatók tudományos felfogásában, addig az 1920-as 1930-as évekre a társadalmi és gazdasági hatótényezők vizsgálata került előtérbe (HAJDÚ Z. 2006). Mindezt 
főként az Egyesült Államokban, de Nyugat-Európában is a választások kvantitatív módszerekkel történő elemzése, amit RICE (1928) módszertani műve alapozott meg (HAJDÚ Z. 1992). A második világháború utáni geográfia kvantitatív forradalmát követően a politikai földrajzon belül is kiemelt fontosságúvá vált a választások térbeli elemzése és a statisztikai okokozati összefüggések feltárása. Ebből adódóan a kvantitatív választási földrajz az 1960-as és 1980-as évek között élte fénykorát (HAJDÚ Z. 1992).

Ehhez az időszakhoz köthető PRESCOTT (1959) kiemelkedő elméleti és módszertani munkássága, ami a szaktudomány dinamikus fejlődéséhez járult hozzá, valamint TAYLOR és JOHNSTON (1979) munkája, amivel az addigi tudományos eredmények összegzésével szisztematikus rendszerré formálták a választási földrajzot. Ebben az időszakban számos publikáció született, ahol kvantitatív és kartográfiai módszerekkel vizsgálták a választások általános összefüggéseit, a kampányra fordított erőforrások választói magatartásra gyakorolt hatását (JOHNSTON, R. 1983) a választókerületek igazságosságát, a gerrymandering és a malapportionment jelenségeit (ERIKSON, S. R. 1972), valamint ezek összefüggését különböző társadalmi és gazdasági mutatókkal (TAYLOR, P. - JOHNSTON, R. 1979). Mindemellett megjelent a lépték kérdésköre (MÉSZÁROS R. 2010), a módosítható területi egység problémája, valamint az állami és társadalmi strukturális keretek szerepe a választási véleményformálásban is (Johnston, R. 1979). Meglátásom szerint az imént felvázolt kutatási témakörök fontosok voltak a választási földrajz fejlődésében, hiszen nagy szerepet játszhattak a manipulációk pontos kimutatásában és a politikai konzekvenciák levonásában is.

Ennek ellenére a politikai földrajzon belül a választási földrajz az 1980-as években fokozatosan kezdett háttérbe szorulni. Erre nagy hatással voltak az általános determinista megközelítéseket megkérdőjelező választási eredmények, valamint a lineáris összefüggéseket erőteljesen átformáló társadalmi és gazdasági folyamatok. Továbbá az is okozhatta a hanyatlást, hogy a kutatások döntő többsége az angolszász országokat vizsgálta, így az ebben a kultúrkörben létrejött eredményeket az eltérő társadalmi és kulturális berendezkedés miatt máshol nehezen lehetett adaptálni. Ez erősítette a választási földrajz és az azon belüli témakörök angolszász centrikusságát, ami álláspontom szerint hozzájárult ezen elképzelések későbbi részleges elszigetelödéséhez az európai geográfián belül.

Mindemellett, a társadalomföldrajz nemzetközi szakirodalom az utóbbi évtizedekben egyre inkább általános elméleti kérdésekkel foglalkozott, így erőteljes társadalomelméleti megalapozottság kezdte jellemezni. Egyre népszerübb lett például a politikai gazdaságtan és a feminista földrajz (LEIB, J. - QUINTON, N. 2011). Ezek a témakörök azért is fejlődhettek könnyebben, mert például a területi és társadalmi egyenlőtlenségek szélesebb kört érintenek, és az ehhez kapcsolódó kutatási eredmények könnyebben voltak értelmezhetőek globálisan. A választási földrajzi kutatók az adatok puszta statisztikai elemzésén túl elfelejtették tágabb társadalmi kontextusba helyezni a feltárt folyamatokat (SHELLEY, F. M. et. al. 1990). Mivel a témakörök döntően angolszász területekre és rendszerekre fókuszáltak és nem lehetett hatékonyan általánosítani a társadalomelméletekkel megtámogatott más társadalomföldrajzi kérdésekkel szemben, ezért a választási földrajz müvelői a kortárs elméleti vitákhoz érdemben nem tudtak hozzászólni. Ebből az következett, hogy az eredmények térbeli elemzése az 1990es évekre visszaszorult még a politikai földrajzon belül is (LEIB, J. - QUINTON, N. 2011).

Az előzőek alapján feltételezhető, hogy számos kutatóban fogalmazódott meg a választási földrajz megközelítéseinek újragondolása. A választási földrajz részlegesen elavulttá válásával már a kilencvenes évek elején foglalkoztak és SHELLEY, JOHNSTON és TAYLOR (1990) álláspontja szerint több fontos tényező mellett az játszhatott szerepet a választási földrajz hanyatlásában, hogy túlságosan pozitivista volt a kutatások szemlélete, ami tudományos munkákban a módszertani megszállottság és a részletekben történő gondolkodás elhatalmasodását eredményezte (LEIB, J. -QUINTON, N. 2011). Mindezek nyomán a választások 
térbeliségének vizsgálatában szükségessé vált a tudományterület elméleti és módszertani megújítása.

WARF és LEIB (2011) szerint négy föbb témakört kell megvizsgálnia a választási földrajznak, hogy meg tudjon újulni, és be tudjon kapcsolódni a szélesebb tudományos párbeszédbe:

1. Meg kell nézni a tudományterület fejlödési pályáját az 1980-as évektől egészen napjainkig és meg kell határozni milyen irányok domináltak;

2. Meg kell vizsgálni, hogy hogyan lehetne a választási eredményeket és térfolyamatokat tágabb kontextusba helyezni és társadalomelméleti koncepciókkal kiegészíteni;

3. Kulcsfontosságú a választások technikai változásainak (elektronikus szavazás, azonosítás, informatikai fejlődés, manipulációk stb.) nyomon követése és új összefüggéseinek feltárása;

4. Ki kell lépni a túlzott angolszász, ezen belül is amerikai dominanciából és több mintaterületet kell vizsgálni, valamint be kell kapcsolni minél több kutatót a társadalmi párbeszédbe (WARF, B. - LEIB, J. 2011).

A korábban részletezett elméleti korlátok ellenére azért megállapítható, hogy voltak olyan tanulmányok és tudományos munkák, amik igyekeztek adaptálni a modern megközelítéseket. Ezek az új választásföldrajzi irányzatok és elméleti megközelítések elvezethetnek minket a szélesebb elméleti megújuláshoz. LEIB és QUINTON (2011) megvizsgálták a választási földrajz legújabb kutatási eredményeit 1990 után, több mint 200 magas presztízsű folyóirat tükrében. Vizsgálatuk a fóáramba tartó tudományos munkákra szorítkozott, hiszen döntően nemzetközileg indexált folyóiratokat elemeztek.

Eredményeik szerint a választási földrajzos publikációk négy témakör köré szerveződtek 1990 után. A kutatásokban még mindig a legnagyobb szeletet az olyan témában írt választási földrajzi tanulmányok jelentették, amelyekben térképre viszik a választási eredményeket, valamint ezekkel kapcsolatban vizsgálják az etnikai, gazdasági, társadalmi és környezeti folyamatokat. A leíró elemzések mellett összetett összefüggéseket és parciális hatásokat egyaránt megállapítanak. Ennek a területnek a fennmaradásában nagy szerep jutott a Földrajzi Információs Rendszer fejlödésének, hiszen ez a kutatások módszertanában jelentős változásokat okozott (LEIB, J. - QUINTON, N. 2011).

A másik nagyobb témakör a választási rendszerek igazságosságának kérdésére. A szerzők olyan kérdésekre keresnek választ, hogy milyenek az igazságosabb választási rendszerek, és a voksolások térbeli folyamatai hogyan hatnak erre. Továbbá megjelenik a pártok szavazatarányai és a képviselői helyek elosztása közötti problematika is. A harmadik fajsúlyos témakör szorosan kapcsolódik a választási rendszerek tágabb elemzéséhez, hiszen ez a választókerületek áttervezését és lehatárolási kérdését járja körbe (WEBSTER, G. R. 2013a). Végül a választási földrajzos publikációkban egy kis szeletet képviselnek a politika és a participáció, valamint a társadalmi igazságosság oktatási kérdéskörei és szempontjai. Itt is föként amerikai mintaterületekkel foglalkoztak, ahol javaslatokat fogalmaztak meg, hogyan lehetne a társadalmi igazságosságot a választási mechanizmusok példáján keresztül tanítani az oktatásban (LEIB, J. - QUINTON, N. 2011).

A főbb kutatási témakörök alapján megállapítható, hogy az elméleti megközelítésekben még mindig a területi elemzések dominálnak, ami meglátásom szerint előrevetíti a választási földrajz fejlődésének további korlátait nemzetközi viszonylatban. Kisebb részben már napvilágot láttak olyan kritikai tanulmányok, ahol a politikai gazdaságtan megközelítései is kiolvashatók (Nicley, E. P. 2011, STEGMAiER, M. - LEWIS-BECK, M. S. 2009, 2011), ugyanakkor ezek továbbra is háttérbe szorulnak. 
A kritikai megközelítések mellett különösen a 2000-res évek végén jelentek meg a posztstrukturalista áramlathoz kapcsolódó publikációk. Ebben az irányzatban fóként a feminista földrajz szerepének növekedését és a nemek közötti eltéréseknek a választói magatartásra gyakorolt hatását érdemes kiemelni. Mindemellett a cselekvőhálózat elmélet és az identitáshoz kapcsolódó posztstrukturalista megközelítések lassú térnyerése tapasztalható a tudományterületen belül. LEIB. és QUINTON (2011) szerint ez egyfajta megkésettségre utal a társadalomföldrajz egyéb területeihez képest, aminek részben az az oka, hogy a választási földrajzos szerzők között más diszciplínával összevetve is szinte alig van nő. Mindemellett véleményem szerint a választási földrajz megújításában a közeljövőben a technológiai változások felgyorsulásának is nagy szerepe lesz. Szemléletem szerint ilyen aktuális kutatási irányok a választási folyamatok elektronikussá válása, a közösségi média és a vélt vagy valós információk áramlásának hatásai a választói magatartásra. Kulcsfontosságú lesz, hogy az imént felsorolt témaköröket hogyan tudja majd a választási földrajz vizsgálni.

A választási földrajzos munkák társadalomelméleti irányultságának formálódása mellett azok mintaterületei is változáson mentek keresztül a korábbiakhoz képest. A nemzetközi választási földrajzi tanulmányokban a korábbi angolszász dominancia nem szünt meg, hiszen a publikációk kétharmada még mindig amerikai vagy angliai mintaterületekről szól, de a részarányuk lassan csökkent (LEIB, J. - QUINTON, N. 2011). A Szovjetunió megszünése és a politikai rendszerek átalakulása után az 1990-es években újra létjogosultságot nyert KeletKözép-Európában is a választási földrajz. Ebből adódóan megjelentek a rendszerváltozáshoz kapcsolódó posztszocialista térséggel kapcsolatos választási földrajzos munkák (FITZMAURICE, J. 1995, HAJDÚ Z. 2006, RÁCZ, B. - KUKORELLI, I. 1995), amelyek az újraéledő demokráciák térbeli tulajdonságait vizsgálták (KITSCHELT, H. 1995, KOLOSSOV, V. 1995, ZARYCKI, T. 1999). Ez a hullám a kétezres évek elejére alábbhagyott, és azóta a fóbb nemzetközi tudományos folyóiratokban lényegesen kevesebb publikáció született erről a térségről (LEIB, J. - QUINTON, N. 2011), ami arra utal, hogy a térségben is szükséges lenne megújítani a választási földrajzot.

A posztszocialista térségben a rendszerváltozást követő választások földrajzi elemzésén (BlaZeK, J. - Kostelecky, T. 1991, JeHLiCKA, P. et al. 1993, KovÁCs Z. 1992, 1993, 2001, Kovács, Z. - DingSdale, A. 1998, Martis, K. C. et al. 1992), a pártok társadalmi beágyazottságának vizsgálatán (BLAZEK, J. - KOSTELECKY, T. 1991, FARKAS GY. 2016, MÉSZÁROS, J. et al. 2007, REGT, S. et al. 2011), a nemzeti kisebbségek választási magatartásán (SzABÓ B. - TÁTRAi P. 2011, 2016) és a szuburbanizáció ilyen irányú hatásain (JANKó F. KOMORNOKI M. 2008, VASÁRUS G. -VIDA GY. 2014) át széles a témakör hazai és nemzetközi szakirodalma. Ha a posztszocialista választási földrajzi publikációk témakörét tekintjük, megállapíthatjuk, hogy a nemzetközi irányzatokhoz képest is döntően pozitivista választási földrajzi tanulmányokat találhatunk. Ezekben különböző leíró, vagy területi statisztikai módszerekkel vizsgálták a pártok társadalmi beágyazottságát a posztszocialista országokban (MArtin, S. 2015, MÉSZÁros, J. et al. 2007, SZABÓ, B. - TÁTRAI, P. 2016), valamint, hogy milyen területi különbségek mutatkoztak a választói preferenciákban, és ennek milyen mozgatórugói vannak.

Ehhez kapcsolódóan idővel számos elméleti jellegü tanulmány is született (LÖWIS, S. 2015), így az általános leíró folyamatok mellett a fantom határok választási földrajzi megjelenésével foglalkoztak részben német (BAARS, R. - SCHLOTTMANN, A. 2015), de föként posztszocialista mintanterületeket (JANCZAK, J. 2015, MARTIN, S. 2015, RAMMELT, H. 2015) vizsgálva. Ezek a tanulmányok a választópolgárok pártpreferenciáinak stabilitása mellett érvelnek, hiszen a történelmi határok később a rendszerek változtatásával megmaradtak, hovatovább a politikai diskurzusban a választói magatartásban is megnyilvánuló térbeli törésvonalakat alkotnak (ZARYCKI, T. 2015). Ez a jelenség hazánkban nem jellemzö, hiszen a trianoni határok meghúzásával a mai Magyarország területén ilyen jelentős történelmi törésvonalak nem alakultak ki, ami közvetett módon is hatna a választási földrajzi 
törésvonalakra. Ez a „fantom határ” jelenség inkább a határon túl rekedt magyarok választói preferenciáiban mutatkozik meg főként Szerbiában, Szlovákiában (SZABÓ, B. - TÁTRAI, P. 2016) és Romániában.

A nemzetközi tapasztalatokat adaptálva a posztszocialista választási földrajzi tanulmányokban is kisebb részben foglalkoztak a szomszédsági hatás, a költségvetési támogatások, kampányköltségek és a választási eredmények összefüggéseivel, ami már befolyással van a választási manipulációk természetére is (LEIB, J. - QUINTON, N. 2011). Így az utóbbi időben a választókerületek manipulációjával a gerrymandering és a malapportionment elemzésével, mögöttes hatótényezőivel is foglalkoztak (BIRCH, S. et al. 2002, GIUGAL, A. et al. 2017, POPESCU, M. - TÓKA, G. 2008). A posztszocialista térségben, ahol a választási rendszer listás és kevésbé lehet a kerületek megrajzolásával hatni a parlamenti mandátumokra, inkább az etnikai kisebbségek jogainak csorbítását lehet kimutatni (BERNAUER, J. - BOCHSLER, D. 2011). Erre egy példa, hogy Szlovákiában a funkcionális közigazgatási határok rajzolásával a magyar kisebbség részarányát és érdekképviseletét igyekezték mérsékelni (HALÁs, M. KLAPKA, P. 2016).

Az imént említett példák mellett azonban megállapítható, hogy a határrajzolási manipulációk részletes elemzése a posztszocialista térség választási földrajzi irodalmában alárendelt szerepet játszott. Ennek részben oka az, hogy a vizsgált országok választási rendszereinek sajátosságai nem adtak jó lehetőséget, hiszen a rendszerváltozást követően döntően listás választási rendszereket adaptáltak, és a gerrymandering, illetve a malaportionment hatásai ezen típusokban nem olyan jelentős, mint például a többségi vagy vegyes szisztémákban.

Másrészt az angolszász és nyugat-európai választási földrajzhoz képest jellemző egyfajta megkésettség a posztszocialista országok tudományos életében, ami alól nem kivétel Magyarország sem. Hazánkban annak ellenére jellemző az elméleti megkésettség, hogy a tudományterület nagyobb múltra tekint vissza. A dualizmus korai népképviseleti rendszerre már Fodor Ferenc elkészítette a korabeli magyar országgyülési képviselőválasztások 18611915 közötti eredményeinek választási atlaszát (HAJDÚ Z. 2017), valamint a két világháború között is foglalkoztak elvétve a választások térképezésével (HAJDÚ Z. 1992). Ezen felül az időközönként megjelenő Országgyülési Almanach sorozataiban is rendszeresen találhatóak választási földrajzi térképek, amiben ezen időszakot is igyekeztek feldolgozni (MARELYN KISS J. et al. 2017) Azonban a választási földrajz akkori periférikus szerepének oka, hogy habár a két világháború között a magyar politikai földrajz fontos szerepet töltött be a geográfián belül, azonban a revizionista törekvések végett a kutatás nagy része a geopolitika és az államhatárokkal kapcsolatos tudományos kérdésekkel foglalkozott. Ezt tetézve a második világháború utáni rövid átmenetet (1945-ös és 1947-es választások) követően az egypártrendszer és a geográfia tudományos pozícióinak meggyengülése miatt a választási földrajz is teljesen eltünt.

Így a rendszerváltozást követően Magyarországon az államszocialista idők történelmi meghatározottságaiból kifolyólag a választási földrajzi kutatásokat döntően nem geográfusok végezték (FÁBIÁN GY. 2017, HAJDÚ Z. 2006). A választások elemzésével elsősorban politológusok (FÁBIÁn Gy. - KovÁCS L. I. 1998, KovÁCS L. I. - STUMPF P. B. 2014), történészek (HUBAI L. 2004, IGNÁCZ K. - SZABÓ B. 2014), közgazdászok és matematikusok (Bíró P. et al. 2012, MÉSzÁros, J. et al. 2007, TASNÁdI, A. 2011) foglalkoztak. Az ő megközelítéseikben időnként megjelentek a térbeli folyamatok és azok hatásai is (BóDI F. BÓDI M. 2011), viszont ez a tudományos párbeszédekben csak marginális szerepet töltött be. Érdemes megjegyezni, hogy HAJDÚ (2006) megállapításával, miszerint a rendszerváltozás utáni geográfia nem foglalkozott érdemben a hazai folyamatokkal részben ellentmond az, hogy KovÁCS (1992, 1993) országgyülési adatokon értelmezett választási földrajzi publikációi az 
angolszász tudományos körökben is érdeklődést váltottak ki (DINGSDALE, A. - KovÁCS, Z. 1996, KovÁcs, Z. - DingSDAle, A. 1998), amit LeIB és QuiNTON (2011) is kiemelt. Ezen felül utóbbi időben is születtek geográfusok tollából is frissebb publikációk (BERTUS, Z. 2016a, b, 2017, HegedÜs G. 2007a, KovalCSIK T. 2018, KovAlCSIK, T. -NZIMANDE, N. P. 2019, SzABÓ B. - TÁTRAI P. 2011, 2016), ami a földrajzosok választások felé irányuló fokozott figyelmét támasztja alá.

Említést érdemelnek az önkormányzati voksolások földajzi elemzései, valamint a roma integráció (TÉSITS, R. - ALPEK, B. L. - SZABÓ, R. 2015) szemüvegén keresztül a kisebbségi választások elemzései, amivel szintén foglalkoztak a hazai kutatók (PÁSZTOR I. Z. 2013, PÉNZES J. et al 2018). Megállapítható azonban, hogy az önkormányzati választások és folyamatok merőben más tematika és szavazói magatartás mentén zajlanak (STUMPF P. B. 2019), mint az országgyülési választások, így ezen elemzések részletesebb bemutatása egy merőben más kutatási irányt alapozna meg.

A magyarországi publikációk közül azt is érdemes kiemelni, hogy választási eredményeket különböző komplex társadalmi és gazdasági mutatóban használták komponensként. Ilyen komplex mutató például a Learn- index, ahol a társadalmi aktivitás vagy közösségi tanulás pillérét alkotta a választási részvételi adat (KozMA T. et al. 2015). Meglátásom szerint is a választási részvétel jól reflektál egy közösség aktivitására, hovatovább bizonyos kapcsolatok is felfedezhetök a jövedelem, a társadalmi státusz és a részvétel között (BóDI F. - BóDI M. 2011). Ebből adódóan a jövőben érdemes lenne erősíteni a választási földrajz eredményinek további beemelését a térségek sikerességének és aktivitásának komplex mérésébe.

Összességében a választási földrajz napjainkban komoly elméleti kihívásokkal néz szembe. A tudományterület folyamatos változáson megy keresztül és szüksége lenne egy átfogó elméleti és módszertani megújulásra azért, hogy a választások geográfiai értelmezése ismét jelentős szerepet töltsön be a politikai földrajzon belül. Mivel a doktori kutatásom aktualitását a magyarországi választási rendszer átalakítása és a választókerületek átszabása adta, ezért disszertációm igyekszik hozzájárulni ehhez a folyamathoz. Mivel a földrajzi különbségeket a választópolgárok is tevékenyen alakítják, így a munkám során mögöttes társadalmi és gazdasági változókat is több szempontból összevetem és elemzem.

\subsection{Választási rendszerek főbb típusai és jellemzői}

A voksolások eredményeinek a kormányzás legitimitását meghatározó keretét a választási rendszerek alkotják. Ezért szükséges megérteni, hogy a választási rendszerek milyen szerepet töltenek be a modern demokráciákban és erről milyen álláspontok alakultak ki az egyes tudományterületek között. Megállapítható, hogy a választási rendszerek nem értéksemleges demokratikus intézmények (STIGLITZ, J. E. 2000), így mindig kedveznek bizonyos jelölteknek vagy politikai pártoknak, míg másoknak hátrányt okoznak. Ezért sok tudományterület foglalkozik a választási rendszerek részletes elemzésével, valamint az igazságosság és arányosság kérdésköreivel. Ilyen terület a politikatudomány (ENYEDI Zs. - KÖRÖSÉNYI A. 2004), a közgazdaságtudomány, a matematika, a számítástechnika és a geográfia is (HAJDÚ Z. 2006).

$\mathrm{Az}$ interdiszciplináris megközelítések és elemzések azon központi kérdés köré szerveződnek, hogy hogyan tudják a választási rendszerek a választópolgárok szavazatait a leghatékonyabban mandátumokká alakítani. Ha megvizsgáljuk a világ országainak választási rendszereit, akkor arra a megállapításra juthatunk, hogy a választási formula szerint három fö 
típust különíthetünk el, amelyek további altípusokra bonthatók (ENYEDI Zs. - KÖRÖSÉNYI A. 2004). Az egyik föbb típus a többségi, a másik a listás, illetve a harmadik a vegyes választási rendszer.

Az angolszász Westminster-modell vagy közismert nevén az egyszerü többségi választási rendszer a legrégebbi hagyományokra tekint vissza, és gyökereit a középkori területi képviselet elvére vezethetjük vissza (ENYEDI Zs. - KÖRÖSÉNYI A. 2004). A demokrácia hajnalán szinte mindenhol ilyen rendszerben szavaztak, így Magyarországon is ez a modell müködött a dualizmus korában (HAJDÚ Z. 2006, 2017). Manapság már döntően csak az angolszász világban használatos, amelynek lényege az, hogy egyéni választókerületekben zajlik a küzdelem és a győztes nyeri a mandátumot (ÁCS N. 2004).

Ebben a szisztémában az a jellemző, hogy a szavazatmegoszlástól függően akár viszonylag alacsony voksaránnyal is mandátumot lehet szerezni. Nincs általánosan meghatározott belépési küszöb, de a rendszerben a kisebb pártoknak nagyon nehéz mandátumhoz jutniuk. Ezekben a választási rendszerekben van a legnagyobb szerepe a térbeliségnek, hiszen jelentősen befolyásolja a mandátumok kiosztását az, hogy hogyan húzzuk meg az egyes választókerületek határait (JOHNSTON, R. 2002a,b, SAUER, C. O. 1918). Emellett a pártok támogatóinak földrajzi eloszlása is jelentős hatással van a végeredményekre. Ebből adódóan plurális demokráciákban átlagosan ezek a rendszerek képezhetik le a legaránytalanabb módon a választói akaratot (MÉSZÁROS J. - SZAKADÁT I. 1993), amit döntően a térbeli tényezők okoznak.

Mivel a kialakított keretfeltételekhez a pártoknak is célszerü alkalmazkodni, így a választási rendszerek idővel hatnak a pártok stratégiájára és a választásokra is. Jellemző politikai következménye ennek, hogy a többségi választási rendszerekben többnyire két erős párt között dől el a választás (ENYEDI Zs. - KÖRÖSÉNYI A. 2004). Ez tapasztalható az Amerikai Egyesült Államokban a demokrata és a republikánus tömörülés mellett nehéz más politikai csoportnak hatalmi pozícióba kerülni. Angliában is erős a konzervatív és a munkáspárt dualitása, de ezt időnként megbontja a liberális demokrata párt, a populista függetlenségi párt vagy a zöldek elöretörése (BORISYUK, G. et al. 2008).

A pártstruktúra dualitása ellenére megállapítható az is, hogy a többségi választási rendszerben a hatalom megszerzésében időnként egy kispárt szokott lenni a mérleg nyelve, ha támogatóinak erős a földrajzi koncentrációja (BORISYUK, G. et al. 2010, MORTIMORE, R. 1992). Továbbá erősebben jelentkezik a stratégiai voksolás szerepe is (JOHNSTON, R. - PATTIE, C. 2011a), hiszen sokan nem arra szavaznak, aki hozzájuk legközelebb áll, hanem akiről azt gondolják, hogy megnyerheti a párharcot a két nagyobb párt képviselöje közül. NagyBritanniában nem egyedi eset, hogy sokszor a liberális pártszimpatizáns, ha pártjára szavazna, akkor az győzne, akit legkevésbé szeretne, így inkább annak legnagyobb riválisára adja le szavazatát (CoX, G. W. 1997). Ez a folyamat jelentősen befolyásolja a választókerületek térbeli torzító hatását, hiszen ilyenkor a kisebb pártok támogatóinak térbeli eloszlása átformálja a mandátumkiosztást is (JOHNSTON, R. 2002a).

Az egyszerü többségi rendszert komoly kritika éri abban is, hogy a leadott szavazatok kevesebb, mint felével is sokszor képviselői helyekhez lehet jutni. Ennek a hiányosságnak a kiküszöbölésére alakult ki az abszolút többségi rendszer. Mivel ez az elv önmagában nem minden esetben jut eredményre, ezért ennek érvényesítésére kétfajta kiegészítő mechanizmust vezettek be az idők során. Az egyik megoldás a kétfordulós választási rendszer, amire példa Franciaország, míg a másik az alternatív vagy preferenciális szavazás kialakítása, amire Ausztráliát lehet felhozni példaként (ENYEDIZs. - KÖRÖSÉNYI A. 2004, JOHNSTON, R. - PATTIE, C. 2011b). Mindkét módosítás próbálja az abszolút többség felé terelni a rendszert, míg a kétfordulós választással a második fordulóba bejutók nagyobb legitimációt szereznek, az alternatív szavazással egyfajta rangsorolást alakítanak ki, ahol vizsgálják a másodlagos és 
harmadlagos preferenciákat a mandátumok kiosztásánál (ENYEDI Zs. - KÖRÖSÉNYI A. 2004). Azonban a gyakorlatban az tapasztalható, hogy ezekkel a módosításokkal sem garantálható biztosan az igazságosabb mandátumkiosztás.

Ez azt hozta magával, hogy a többségi rendszerekkel szemben vannak olyan országok, ahol tisztán listás, arányos modellt alkalmaznak (AGG Z. - NEMES NAGY J. 2002, Ács N. 2004). Itt nincsenek képviselöjelöltek, hanem pártlistákra lehet szavazni, és a végén, aki a legtöbb szavazatot nyeri el, az alakíthat kormányt. Ennek előnye, hogy sokkal arányo sabban képezi le a választók akaratát, hiszen a mandátumok száma arányban közel akkora lehet, mint a voksoláson elért arány (MÉSZÁros J. - SZAKADÁT I. 1993). Viszont a listára szavazás egyik hátránya, hogy nehezen alakul stabil kormány, többnyire koalíciós partnert kell találni, ami megnehezíti egy ország irányítását.

További problémát jelent, hogy az egyéni rendszerhez hasonlítva a választópolgárok sokszor egyáltalán nem ismerik azokat a képviselőket, akire szavaznak, hiszen a szavazólapon csak a párt neve szerepel. Ez felerősíti a helyi politika országos képviseletének további kiüresedését. Földrajzi szempontból fontos kiemelni, hogy az arányosabbnak mondott listás választási rendszerekben is kialakulhatnak nagy különbségek a szavazatarány és a mandátumarány között, hiszen előfordul, hogy valamilyen országosnál kisebb területi beosztás alapján aggregálják a szavazatokat, úgy mint Portugáliában, amivel jelentősebb földrajzi aszimmetriák és torzulások is létrejöhetnek (LAGO, I. - LOBO, M. C. 2014).

Az előző gondolatból adódik, hogy a harmadik főbb típus az egyéni választókerületi és a listás rendszer előnyeit próbálja kombinálni, amit a német vagy más néven vegyes modell jelent. Itt a voksolásokon a szavazó listára és egyéni képviselőre is leadhatja szavazatát. Az így kialakuló eredmény is részben a győztes felé torzítja a képviselők arányát, de mégsem olyan mértékben, mint a többségi rendszer (MÉSZÁROS J. - SZAKADÁT I. 1993, ÁCS N. 2004). Ebben a modellben általában területi listák vannak, melyek a szavazatarányoknak megfelelően eredményeznek mandátumokat, valamint az egyéni kerületekből is be lehet jutni a törvényhozásba. Hátránya, hogy nagyon bonyolult módszerrel osztják el a töredékszavazatokat, és nehéz átlátni a folyamatokat. Fontos megjegyezni, hogy a listás és a vegyes választási rendszerekhez hozzátartozik egy bizonyos küszöbérték, amit el kell érni a pártoknak. Ez többnyire 3-5 \% körül szokott mozogni, de például Törökországban 10 százalékot is meghatároztak (ENYEDI Zs. - KÖRÖSÉNYI A. 2004, KOVALCSIK T. 2018). Minél magasabb a küszöbérték, annál inkább a kispártok és az arányos képviselet ellen dolgozik a választási rendszer. Összegezve meghatározhatók a választási rendszerek típusainak előnyei és hátrányai (1. táblázat).

Mindebből adódik, hogy a szavazatok leképezésében szerepet játszó összetett tényezők miatt nincs tökéletesen igazságos választási rendszer, de konszenzus van abban, hogy célszerü törekedni a választópolgárok arányos képviseletére. Párstruktúrától függően tulajdonképpen mindhárom föbb választási rendszerben fontos az arányosság, ami követendő célként határozható meg. Ennél fogva a választási rendszerek igazságosságának vizsgálata régóta foglalkoztatja a társadalomtudósokat. RAWLS $(1971,1997)$ szerint a politikai szabadság és népképviselet egyik feltétele az, hogy a választási rendszer arányosan képezze le az állampolgárok akaratát, tehát közel azonos számú állampolgárt képviseljen egy-egy parlamenti képviselő (YounG, I. 1990).

Publikációk széles köre vizsgálja a többségi, a listás és a vegyes választási rendszerek általános mandátumkiosztási arányosságának jellemzőit (FÁBIÁN GY. - KOVÁCS L. I. 1998, KovÁcs L. I. - StumPF P. B. 2014, MÉszÁros J. - SZAKADÁT I. 1993), valamint ezeknek a pártrendszerre gyakorolt hatásait (BENOIT, K. 2004, GALlAGHER, M. - Mitchel, P. 2005, MASSICOTTE, L. - Blais, A. 1999). Azonban a politológusok többször a térbeliség szerepét kevésbé hangsúlyozó vizsgálatokból következtetnek egy adott választási rendszer általános 
aránytalanságára, holott a földrajzi tér jelentős szerepet játszik a mandátumok egyenlőtlen kiosztásában ott, ahol valamilyen térbeli beosztás alapján összesítik a szavazatokat. Ebből adódóan a szakirodalmak feldolgozását követően célszerü kiemelni, hogy a politikatudomány által használt választási rendszerek aránytalansága nem azonos a később részletezett „földrajzi torzulások”, vagy a „választási rendszerek területi aránytalanságainak" fogalmával. Ezen földrajzi tényezők fogalomrendszerét a rendszerváltozást követő magyar választási rendszer sajátosságainak és változásának leírását követően fejtem ki.

1. táblázat: A választási rendszerek főbb típusai és általános jellemzőik

\begin{tabular}{|c|c|c|c|}
\hline Típus & Többségi & Arányos & Vegyes \\
\hline Főbb altípusok & $\begin{array}{l}\text { Egyszerü többségi, } \\
\text { Abszolút többségi }\end{array}$ & $\begin{array}{l}\text { Országos lista, } \\
\text { Területi lista }\end{array}$ & $\begin{array}{l}\text { Egyéni jelöltek és } \\
\text { pártlisták egyaránt }\end{array}$ \\
\hline A rendszer előnye & $\begin{array}{l}\text { Nagyfokú stabilitás, erős } \\
\text { földrajzi és } \\
\text { társadalmi (pl. etnikai) } \\
\text { érdekképviselet }\end{array}$ & $\begin{array}{l}\text { Matematikailag } \\
\text { igazságos és arányos } \\
\text { mandátumkiosztás }\end{array}$ & $\begin{array}{l}\text { Vegyíti a többségi és az } \\
\text { arányos } \\
\text { rendszer előnyeit }\end{array}$ \\
\hline A rendszer hátránya & $\begin{array}{l}\text { Matematikailag torzított } \\
\text { mandátumkiosztás }\end{array}$ & $\begin{array}{c}\text { Gyenge a helyi } \\
\text { érdekérvényesítés és } \\
\text { állampolgári kontrol, a } \\
\text { pártarisztokrácia } \\
\text { hatalma érvényesül }\end{array}$ & $\begin{array}{l}\text { Bonyolult a mandátumok } \\
\text { kiosztásosának módszere }\end{array}$ \\
\hline $\begin{array}{l}\text { A földrajz szerepe a } \\
\text { választási rendszerben }\end{array}$ & Kizárólagos & Mérsékelt & Hangsúlyos \\
\hline Példák & $\begin{array}{l}\text { Azerbajdzsán } \\
\text { Nagy-Britannia } \\
\text { Új-Zéland }\end{array}$ & $\begin{array}{l}\text { Hollandia } \\
\text { Lettország } \\
\text { Szlovákia }\end{array}$ & $\begin{array}{l}\text { Magyarország } \\
\text { Németország } \\
\text { Oroszország }\end{array}$ \\
\hline
\end{tabular}

Forrás: ENYEDI Zs. - KöRÖSÉNYI A. 2004 alapján saját szerkesztés

\subsection{A rendszerváltozás utáni magyar választási törvények főbb tulajdonságai és földrajzi sajátosságai}

Magyarországon a rendszerváltozás során az 1989. évi XXXIV. törvény rendelkezett a szabad választásokról, amely vegyes, többségi és részben arányos pilléreken is nyugvó választási rendszert vezetett be a német modellhez hasonlóan. Választójogot kapott minden nagykorú állampolgár, aki nincs eltiltva a közügyek gyakorlásától. Minden választópolgárnak két szavazata volt, az egyiket listára, míg a másikat egyéni képviselőjelöltekre adhatta le. A szavazatok alapján a 2014-es országgyülési választásokig 386 mandátum került kiosztásra. Ez egyrészt úgy oszlott meg, hogy 176 egyéni választókerületre osztották fel Magyarországot (1. ábra), és itt versenyezhettek a pártok által támogatott vagy független jelöltek. Az 1990 és 2014 között müködö rendszerben a választókerületek méretére vonatkozóan volt egy olyan feljegyzés, hogy a megyehatárok megkötésével számolva körülbelül 60 ezer választópolgár alkosson egy egységet (1989. évi XXXIV. törvény), ezt azonban a gyakorlatban nem 
alkalmazták. További lehatárolási elvként megjelent az egyéni választókerületek kialakításánál, hogy lehetőség szerint figyelemmel kellett lenni a nemzetiségi, vallási, történelmi és egyéb helyi sajátosságokra is, és város és vonzáskörzete lehetőleg egy választókerületet kellett alkosson (1989. évi XXXIV. törvény).

\section{1. ábra: Az országgyülési egyéni választókerületek beosztása 1990 és 2010 között}

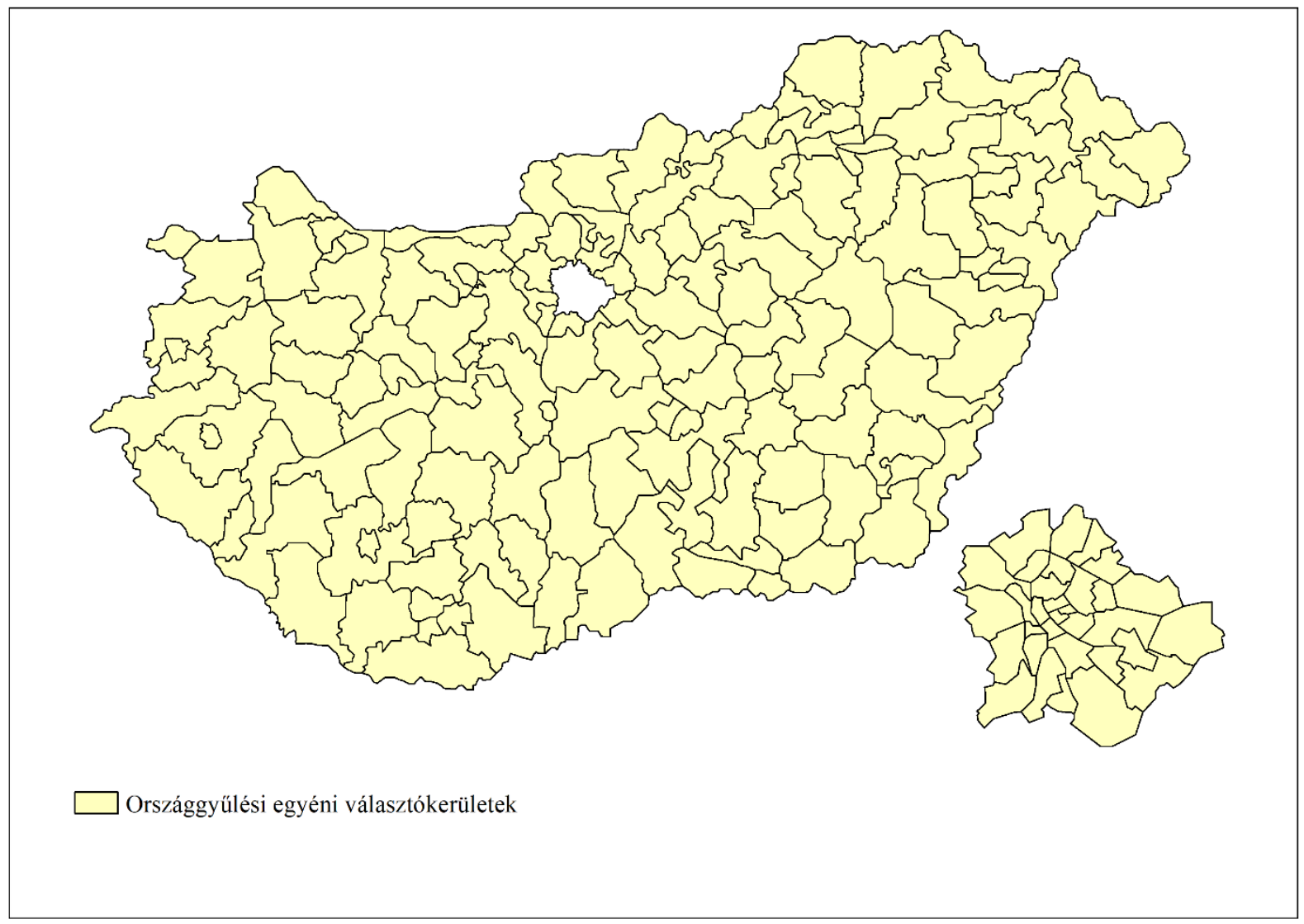

Forrás: Nemzeti Választási Iroda és HEGEDűs G. 2007a alapján saját szerkesztés

A jelöltállításhoz 750 darab választói ajánlás vagy más néven kopogtatócédula volt szükséges. A választás csak abban az esetben volt érvényes, ha a választásra jogosultak több mint a fele részt vett a szavazáson. Ha egyik jelölt sem tudott abszolút többséget szerezni (az érvényes voksok 50 százaléka plusz 1 szavazat), abban az esetben második fordulót tartottak. A második fordulóban a szabályokon alapulva többnyire a három legtöbb szavazatot szerző jelölt mérettette meg magát, és itt már a relatív többség is elegendő volt a mandátum elnyeréséhez.

Az egyéni képviselőválasztás mellett az arányos választási rendszerre jellemző pártlisták alkották a választási rendszer másik pillérét (BöHM A. 2003). Magyarországon az összes megye és a fóváros is egy területi választókerületet alkotott. Egy párt vagy mozgalom akkor indíthatott listát egy megyében, ha az egyéni választókerületek egynegyedében, de legalább kettőben jelöltet tudtak állítani (pl. Csongrád megyében 2014-ig elég volt, ha a hétböl két helyen indítottak egyéni jelöltet). Országos listát csak olyan párt vagy szervezet állíthatott, aki legalább hét megyei listát fel tudott állítani. 
A választópolgárnak a szavazáskor két voksa volt, egyiket egyéni képviselöjelöltre, a másikat pedig listára adhatta. Ezenkívül létezett még egy országos lista is, amely arányosító funkciót töltött be a mandátumok kiosztásában. Az országos listára az egyéni szavazásokon keletkező töredékszavazatok és a mandátumot nem érő megyei voksok kerültek fel. Töredékszavazatnak minősült az az egyéni jelöltre vagy megyei listára leadott szavazat, ami nem eredményezett mandátumot.

A megyei listán összegyült voksokat 2014-ig egy viszonylag bonyolult matematikai eljárással, a Hagenbach-Bischoff módszerrel számították ki. Továbbá a töredékszavazatokból létrejött országosan aggregált voksokat a d'Hondt-féle számítás formálta parlamenti helyekké. Így a 386 képviselői hely elméletben 176 egyéni választókerületi, 152 megyei listás és 58 országos listás helyből állt. Érdemes megjegyezni, hogy a földrajzi torzulásoknak is köszönhetően a területi listák szinte soha nem 152 és 58 arányban osztódtak el, hanem az országos listáról többen jutottak mandátumhoz. Ez úgy alakult, hogyha a megyei listákon nem talált gazdára az összes hely, akkor automatikusan a töredékszavazatok alapján az országos listán juthatott be több képviselö.

1990-től többször módosították az országgyülési választási törvényt (1994. évi III. törvény, 1997. évi XCVI. törvény, 1997. évi C. törvény), de átfogó reformokra sokáig nem került sor. A 2000-es évek elejétöl folyamatosan a politika kereszttüzébe került az országgyülési képviselők számának csökkentése és a választókerületek áttervezése, de ezek a kellő politikai támogatás megszerzése nélkül (a mindenkori kompromisszumkészség hiánya, a népszavazás elmaradása stb.) kudarcba fulladtak. A 2010-es országgyülési választásokon győztes Fidesz-KDNP már a hivatalba lépése elött közölte, hogy a kormányzati ciklus alatt alkotmányt szeretne módosítani, amelyre a választópolgárok végül felhatalmazták őket. Az új alaptörvény mellett a sarkalatos választójogi törvények megváltoztatására is vállalkoztak, amit az ellenzéki pártok közül senki sem támogatott, és népszavazás sem volt erröl. Végül az országgyülési képviselök választásáról szóló új törvény 2011-ben, a választási eljárási törvény pedig 2013-ban lépett hatályba, ami eltért a korábban megszokott voksolási keretfeltételektől.

A 2011. évi CCIII. évi törvény számos újítást tartalmazott az 1989-eshez képest (2. táblázat). A parlamenti képviselök számát 386-ról 199-re csökkentették, ez 106 egyéni választókerületi és 93 listás helyből állt össze. Így változott a listás és többségi (egyéni választókerületi) helyek aránya is. A korábbi kétfordulós választásokat felváltotta az egyfordulós, így a kerületekben elég volt relatív többséget szerezni, ami az amerikai és angol rendszerhez hasonlatos (ILONSZKI, G.-VÁRNAGY, R. 2016). Ez egyértelmüen a nagypártoknak kedvező, hiszen a kisebb pártoknak nincs lehetőségük megegyezni kölcsönös visszalépésekről a két forduló között, egyedül meg kevés esélyük van egyéni kerületekből mandátumokat szerezni. Így a jelenlegi politikai helyzetben a kisebb pártoknak már előre meg kell egyeznie más formációkkal a kölcsönös visszalépésekről, ami erodálhatja szimpátiájukat.

A vegyes választási rendszer pártlistás pillérénél megszűnt a megyei lista és a listaállítás szabályai is módosultak. Ezentúl az a párt állíthatott listát, amely legalább kilenc megyében és a fóvárosban összesen 27 egyéni választókerületben jelöltet tudott állítani. Regisztrációt követően egy országgyülési választókerületben a korábbi 750 kopogtatócédula helyett 500 aláírást kellett összegyüjtenie annak, aki indulni akart. Ez jelentős könnyítés volt, hiszen korábban a választókerületekben való megmérettetéshez kevesebb szavazóból kellett több kopogtató cédulát összegyüjteni. További könnyítést jelentett, hogy az ajánlásnál egy választópolgár több képviselőt is javasolhat, ez könnyíti a választáson való indulást. Ezek a folyamatok felerősítették az úgynevezett „bizniszpártok” előretörését, ami 2014-ben és 2018ban is a pártok finanszírozási eljárása miatt jelentős állami pénzügyi erőforrást emésztett fel. Megmaradt ugyanakkor a korábban is (1994-től) alkalmazott szürő, az 5\%-os bejutási küszöb, amit még mindig nehéz megugrani a kisebb szerveződéseknek [1]. 
A töredékszavazatok eloszlásában mégis hátrányba kerültek a kispártok, hiszen 2014-től az egyéni választókerületekben a győztesek is kaptak töredékszavazatot. A törvény úgy rendelkezik, hogy a győztes jelöltre leadott voksokból ki kell vonni a második helyezett szavazatait és plusz egyet, az azon felül kapott voksokat pedig töredékszavazatként el lehet számolni. Érdemes ezért azt is megjegyezni, hogy elméletben ebben a választási szisztémában viszonylagosan kisebb a szerepe az olyan választókerületi lehatárolásnak, ahol szándékosan hagyjuk túlnyerni a riválist, hiszen ő is kap töredékszavazatot a győzelmén felül.

2. táblázat: A rendszerváltozás utáni magyar választási rendszerek főbb jellemzői

\begin{tabular}{|c|c|c|}
\hline & Korábbi választási rendszer & Jelenlegi választási rendszer \\
\hline Első gyakorlati alkalmazás & 1990 & 2014 \\
\hline Képviselők száma & 386 & 199 \\
\hline $\begin{array}{c}\text { Jelöltállításhoz } \\
\text { szükséges ajánlások száma }\end{array}$ & 750 kopogtató cédula & 500 ajánlás \\
\hline Szavazás menete & Két forduló & Egy forduló \\
\hline $\begin{array}{c}\text { Választópolgárok szavazatának } \\
\text { száma }\end{array}$ & Két szavazat & Két szavazat \\
\hline $\begin{array}{l}\text { Országgyülési egyéni } \\
\text { választókerületek száma }\end{array}$ & 176 & 106 \\
\hline Területi lista & + & - \\
\hline Országos lista & + & + \\
\hline $\begin{array}{c}\text { Választási } \\
\text { küszöbérték }\end{array}$ & $5 \%$ & $5 \%$ \\
\hline $\begin{array}{c}\text { Listás voksok és } \\
\text { töredékszavazatok } \\
\text { mandátumkiosztásának módszere }\end{array}$ & $\begin{array}{l}\text { Hagenbach- } \\
\text { Bischoff, } \\
\text { d'Hondt féle számítás }\end{array}$ & D’Hondt féle számítás \\
\hline Győzteskompenzáció & - & + \\
\hline Határon túli levélszavazatok & - & + \\
\hline Nemzetiségi lista & - & + \\
\hline
\end{tabular}

Forrás: A 1989. évi XXXIV. és a 2011. évi CCIII. törvény alapján saját szerkesztés

Fontos elem 2014 után, hogy a határon túli kettős állampolgársággal rendelkező magyarok is kaptak szavazati jogot, bár akinek nincsen magyarországi lakóhelye, az csak a listára voksolhat [1]. Itt fontos megjegyezni az országok közötti különbségeket is, hiszen Romániában élhettek a kettős állampolgársággal a magyarok, míg Szlovákiában ezt nem tehették meg. Tehát a listás szavazatoknál összegződnek a határon túli voksok mellett a töredékszavazatok is, ami azt jelenti, hogy a korábbiakhoz képest közel kétszeres vokshalmaz alakul ki, ami a matematikai mandátum-kiosztási módszerek és az egyszerüsödés miatt a pártok országos eredményével arányosabb listás mandátumkiosztást eredményez, de gyengíti a 
kompenzációs jelleget. Mindemellett az újabb választási rendszer sajátossága, hogy kialakultak úgynevezett nemzetiségi listák is, amelyről kevesebb vokssal is parlamenti mandátumot lehet szerezni, ami például már 2018-ban sikerült is a német kisebbségnek.

Földrajzi szempontból az igazán központi kérdés azonban az új választókerületek kialakításának mikéntje, és az új beosztás földrajzi igazságossága. Az új választási törvény a korábbi 176 egyéni választókerület helyett 106-ot alakított ki (2. ábra). Megállapítható, hogy az országgyülési egyéni választókerületek közötti eltérések nagyságát az alábbiakban határozták meg a törvényalkotók: „Az egyéni választókerületek választásra jogosultjainak száma az egyéni választókerületek választásra jogosultjainak országos számtani átlagától tizenöt százaléknál nagyobb mértékben - a földrajzi, nemzetiségi, történelmi, vallási és egyéb helyi sajátosságokat figyelembe véve - kizárólag a 2. bekezdés a és b pontjában foglaltak érvényesülése érdekében térhet el" (2011. évi CCIII. törvény az országgyülési képviselök választásáról 4. cikk 4. bekezdés). Ez magában foglalja a megyehatárok sérthetetlenségét, valamint az egybefüggő választókerületek megkövetelését.

\section{2. ábra: Az országgyűlési egyéni választókerületek beosztása 2011 után}

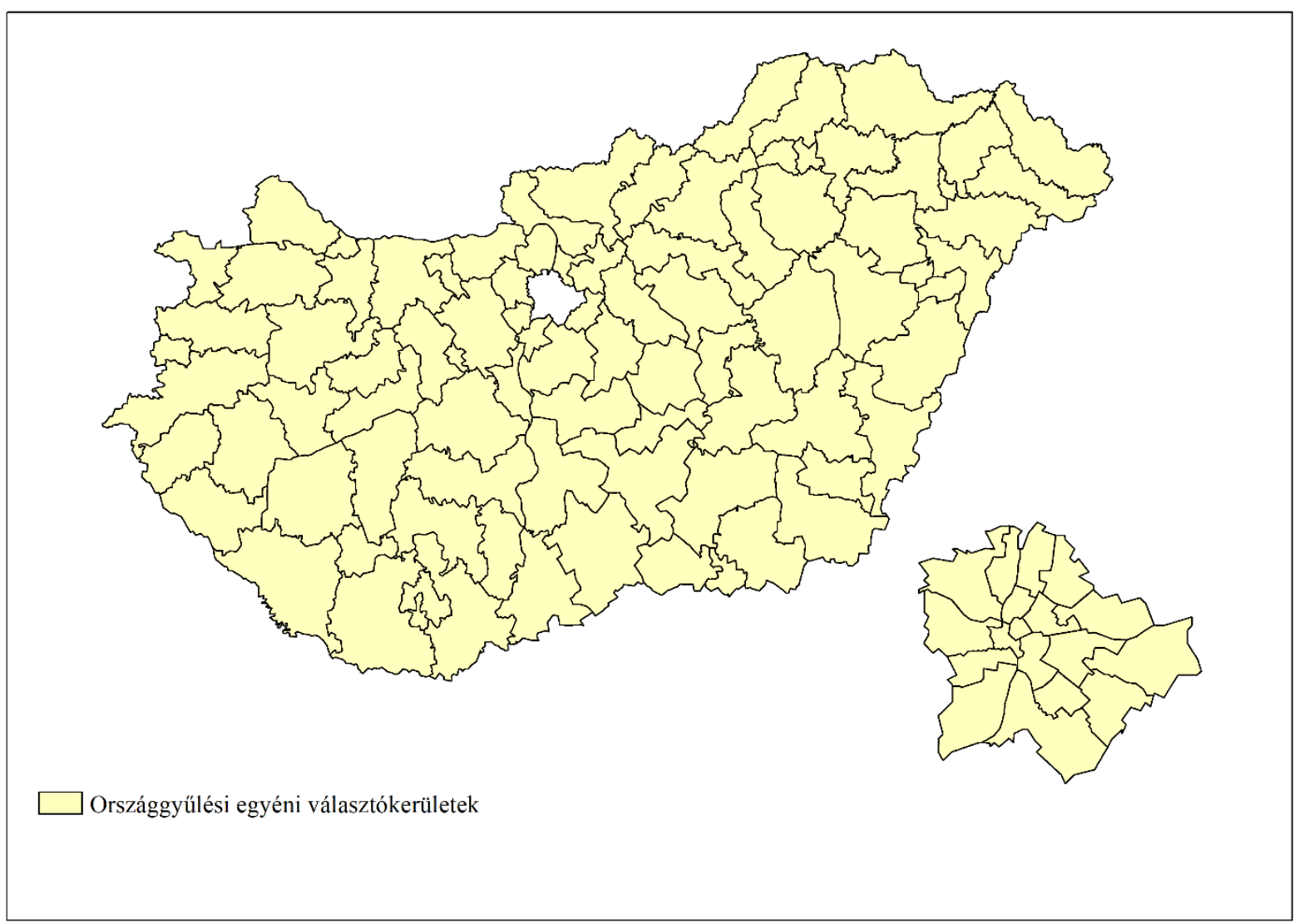

Forrás: A Központi Statisztikai Hivatal és a Nemzeti Választási Iroda alapján saját szerkesztés

Mindemellett a 2011-es törvény azt is megállapítja: „ha az eltérés meghaladja a húsz százalékot, az Országgyülés a 2. számú mellékletet módositja. Az országgyülési képviselők általános választását megelözö év első napja és az országgyülési képviselök általános választásának napja közötti időben - az Országgyülés feloszlása vagy feloszlatása miatti választás kivételével - nem kerülhet sor a 2. számú melléklet módosítására" (2011. évi CCIII. törvény az országgyülési képviselők választásáról 4. cikk 6. bekezdés). 
A jogszabályokat értelmezve földrajzi szempontból jelentős komponens a törvényben, hogy megkövetelték az egybefüggő választókerületeket. Ezért már 2013-ban is felülvizsgálták a kerületi beosztást, és többek között a szegedi választókerületeket is módosították, mert a lehatárolás alapján egyikük nem volt egybefüggő. Fontos megállapítani, hogy a nemzetközi angolszász gyakorlathoz (WEBSTER, G. R. 2013a,b) részben illeszkedve a magyar jogszabályban a hagyományos tényezők mellett további kritériumok is megjelentek, hiszen kiemelik, hogy a kerületrajzolásnál a földrajzi, nemzetiségi, történelmi, vallási és egyéb helyi sajátosságokat is figyelembe kell venni. Mindemellett megállapítható, hogy a gyakorlatban a hazai választókerületek megalkotásának kritériumai közül az objektív külső térfelosztási szempontok (FOREST, B. 2013, WEBSTER, R.G. 2013a,b) játszották a vezető szerepet. Komoly problémát jelent az új beosztásnál - a nagyobb átlagos méretek miatt - a „megyehatárok szentsége", vagyis, hogy a megyék határát egy választókerület sem keresztezheti (KovÁcS, Z. - VIDA, Gy. 2015, VIDA Gy. - KovÁCS Z. 2015). Így a megyénként eltérő felnőtt lakosságszámhoz igazodó térfelosztás komoly földrajzi kihívást jelentett.

Összességében az új választási rendszer megmaradt vegyesnek, de egy kicsit a többségi rendszerelemek súlya nőtt. A korábbi „egyenlö lakosság” elvében történt némi elörelépés, hiszen konkrétabb korlátokat vezettek be, viszont az elméleti részben kifejtett posztszocialista országok jogszabályaival összehasonlítva még mindig viszonylag megengedő. Ezen túlmenően az egyéni mandátumok aránya is magasabb, mint a listásoké. Erős szürővel rendelkezik a szisztéma az újonnan alakuló pártokkal szemben, hisz az 5\%-os bejutási küszöb az ajánlószelvények viszonylag kisebb száma mellett is nehéz feladat a tökehiányos civil mozgalmaknak, pártoknak.

Megállapítható, hogy a listás szavazatoknál összegződnek majd a töredékszavazatok is, ami azt jelenti, hogy a részvételhez képest közel kétszeres vokshalmaz alakul ki, ami a kompenzáció oldódása miatt szintén a kispártokat hozza hátrányos helyzetbe. A választási rendszer inkább a kétpólusú politikai versenyt támogatja (két nagy párt), illetve a 2010 után kialakult pártstruktúrát (egy centrális nagypárt dominanciája és több közép- és kispárt) látszik stabilizálni.

\subsection{Választási rendszerek földrajzi torzulásai és azok nemzetközi értelmezései}

Az állampolgárok naponta döntenek arról, hogy például árut vagy szolgáltatást vásárolnak. Ezzel az emberek folyamatosan meghatározzák és alakítják környezetüket. A dollárszavazatok mellett a demokráciákban bizonyos idöközönként szükséges választási döntéseket is meghozniuk, ahol politikai véleményt nyilvánítanak és meghatározzák szükebb vagy tágabb közösségük fejlödésének irányait. Ebböl adódóan a demokratikus országok életében az egyik központi kérdés, hogy hogyan lehet a választópolgárok szerteágazó véleményét összegyüjteni és azt minél igazságosabban érvényre juttatni. Ebben kulcsszerepet kapnak a választási rendszerek, ami a közösségi döntésekben tulajdonképpen a szándékok összevonásának mechanizmusaként jelenik meg. Ezért szükséges bemutatni az egyenlőtlen mandátumkiosztást meghatározó földrajzi hatótényezőket.

Megállapítható, hogy a választási rendszerek általános aránytalanságát többszörösen összetett térbeli folyamatok is formálják, így a földrajz központi szerepet kap azokban a képviseleti demokráciákban, ahol a szavazatokat valamilyen területi beosztás alapján vonják össze (JoHnston, R. 2002a, 2015). Még az arányosabbnak mondott listás választási rendszerekben is érzékelhető a hatás, ahol valamilyen országosnál kisebb területi beosztás szerint aggregálják a szavazatokat (LAGO, I. - LOBO, M. C. 2011). Azonban a geográfia legfontosabb szerepet kétségkívül a többségi, valamint a vegyes választási rendszerekben kap, 
hiszen itt a mandátumok egészét vagy jelentős részét egyéni választókerületekben lehet megszerezni (JOHNSTON, R. - PATTIE, C. 2011a,b).

Számos, főként angolszász publikáció és kutatás bizonyítja (LEIB, J. - QUINTON, N. 2011), hogy az elmúlt évtizedekben a választási földrajzban is meghatározó témakör lett a rendszerek aránytalanságait okozó választókerület-átrajzolás kérdése, valamint ennek hatása a mandátumszerzésre. E témakörön belül egyrészt azt vizsgálják, hogy a választási rendszerek térben hogyan képezik le a leghatékonyabban a képviseletet és földrajzi szempontból mennyire arányos a politikai képviselet. Másrészt a választási részvétel átfogó legitimációjával és az igazságosság térbeli kérdéseivel foglalkoznak. Ebbe a kutatási irányzatba illeszkedik a választókerületek megrajzolásával járó torzulások kimutatása is (LEIB, J. - QUINTON, N. 2011).

A nemzetközi földrajzi szakirodalomban egyetértés van abban a tekintetben, hogy a választási rendszerek földrajzi vagy területi aránytalansága (disproportionality) önmagában minden olyan szisztémában jelen van (BORISYUK, G. et al. 2008, GROFMAN, B. et al. 1997, PATtie, C. - Johnston, R. 2014), ahol a szavazatokat valamilyen országos szintnél kisebb beosztásban aggregálják. Ugyanakkor mindaddig szimmetrikus és igazságos, amíg ezek a térbeli felosztásból eredő aránytalanságok ugyanolyan mértékben juttatják előnyhöz bármelyik politikai pártot (ERIKSON, S. R. 1972, GELMAN, A. - KING, G. 1994, GROFMAN, B. et al. 1997). Amennyiben a földrajzi folyamatokból adódóan ugyanaz a szavazatarány az egyik politikai oldalt nagyobb mandátumarányhoz juttatja, mint a másikat, akkor a választási rendszer területi torzulását (bias) lehet megállapítani (BORISYUK, G. et al. 2009, ERIKSON, S. R. 2002, JOHNSTON, R. et al. 1999, PATtie, C. - Johnston, R. 2014).

Ezek a földrajzi torzító hatótényezők néhány kivétellel (JoHnSTON, R. 2015, ZuCCO, C. 2007) többnyire a legnagyobb szavazatarányt elért pártokat hozzák kedvező helyzetbe, így sokszor a szakma használja a győztes bónusza (winner's bonus), a többségi torzulás (majoritarian bias), a választási torzulás (electoral bias) (PATTIE, C. - JOHNSTON, R. 2014), párttorzulás (partisan bias) (GrOFMAN, B. et al. 1997, SAUGER, N. - GrOFMAN, B. 2016) és a túlzás (exaggeration) fogalmakat is (CURTICE, J. - STEED, M. 1986), amikor leírják a folyamatokat (BORISYUK, G. et al. 2008, BORISYUK, G. 2012). Ebből a szerteágazó fogalomhasználatból disszertációmban igyekeztem egy átfogó magyar fogalmat meghatározni, ami leírja a választási rendszerek területi hatótényezőit. Így az egyenlőtlen politikai reprezentációt létrehozó területi folyamatokat összefogóan földrajzi torzulásoknak nevezem, ami magyarul keretbe foglalja az imént említett nemzetközi fogalmakat. Tehát a fenti szakirodalom szintetizálása alapján meghatározásom szerint: a földrajzi torzulás fogalma magában foglalja mindazon választással kapcsolatos térbeli tényezöket, ami a mandátumkiosztásban egyenlötlen politikai reprezentációt hoz létre.

A választási rendszerek térbeli folyamatainak sokrétüségéből következik, hogy a földrajzi torzulásokat több résztényezőre lehet bontani, amit BROOKES, R. H. (1953, 1959, 1960) determinánsokként határozott meg. Ezek a következők: 1. a választókerületek közötti különbségek a választópolgárok száma tekintetében; 2. a szavazói távolmaradások; 3. a pártok szavazatarányainak térbeli eloszlása, és 4. a harmadik pártra, vagy egyéb kispártokra leadott voksok hatása (BROOKES, R. H. 1953, 1959, 1960). Ezt a szemléletet JOHNSTON (2002a) továbbfejlesztette és a földrajzi torzulás mértékére ható tényezőket a pártok szavazóbázisának földrajzi különbségeivel, valamint az eltérő választásra jogosult lakosságszámmal rendelkező választókerületek területi eltéréseivel hozta összefüggésbe. Így hat részkomponenst határozott meg, ami tulajdonképpen a gerrymanderinget, a malapportionmentet foglalja magában (3. táblázat). Előnye ennek az elméleti megközelítésnek a GELMAN - KING (1994), GROFMAN és munkatársai (1997) által használt komolyabb szimmetriát elemző matematikai logikára építő elmélettel szemben, hogy a földrajzi torzulást meghatározó résztényezőket könnyebben szét 
lehet választani, továbbá értelmezni lehet öket olyan rendszerekre is, ahol a pártstruktúrát több mint két párt dominálja.

A nemzetközi választási földrajzban döntően a többségi választási rendszerre és ezen belül a kétpólusú pártstruktúrára vonatkoznak a földrajzi torzulások kutatásának eredményei, melyek föként az Egyesült Királyságra és az Egyesült Államokra vonatkoznak (LEIB, J. QUINTON, N. 2011). Mivel a magyar vegyes választási rendszerben is találhatóak egyéni választókerületek, ezért meglátásom szerint az angolszász választási földrajzi elméletek a magyar viszonylatra is használhatók. Ebböl adódóan értekezésemben a JOHNSTON (2002a) féle elméleti értelmezést igyekeztem a magyarországi helyzetre alkalmazni.

Megállapítható, hogy a földrajzi torzulások JOHNSTON (2002a) féle elméleti értelmezésében a nagyobb közigazgatási területek közötti és ezen belüli választókorú népességszámbeli különbségek hatásai együttesen okozzák a malapportionmentet. Fontos megjegyezni, hogy a kerületek méretbeli eltéréseit a választásra jogosultak számbeli eltéréseiként értelmezi a szakirodalom. Emellett a pártokra leadott fölöslegesnek és elpazarolt szavazatoknak az eloszlását értelmezhetjük gerrymandering hatásnak, hiszen az elméleti megközelítés a mandátumok megszerzésének hatékonyságát helyezi elötérbe. Ha túl nagy különbséggel győz a párt a választókerületben, vagy elveszíti a mandátumot, azt kevésbé hatékony szavazati eloszlásnak értelmezhetjük, ami utal a tökéletesen homogén választókerületek kialakítására, vagy a szavazótábor térben kevert szétszóródására (JOHNSTON, R. 2002a).

3. táblázat: A földrajzi torzulásokat meghatározó résztényezők elméleti koncepciója

\begin{tabular}{|c|c|}
\hline \multicolumn{2}{|l|}{ Malapportionment: } \\
\hline & $\begin{array}{l}\text { Választókerületek nagyobb közigazgatási határokon belüli méretbeli } \\
\text { különbségei }\end{array}$ \\
\hline & $\begin{array}{c}\text { Választókerületek nagyobb közigazgatási határok közötti méretbeli } \\
\text { különbségei }\end{array}$ \\
\hline \multicolumn{2}{|l|}{ Gerrymandering: } \\
\hline & $\begin{array}{l}\text { A hatékony mandátumszerzéshez a nagyobb pártok } \\
\text { támogatottságának térbeli eloszlása }\end{array}$ \\
\hline \multicolumn{2}{|l|}{ Reactive malapportionment: } \\
\hline & A választási részvétel eltérései a kerületekben \\
\hline & Harmadik és egyéb pártok szavazatainak eloszlása \\
\hline & Harmadik és egyéb pártok mandátumgyőzelmei \\
\hline
\end{tabular}

Forrás: JOHNSTON, R. 2002a alapján saját szerkesztés 
Megállapítható, hogy egy választási rendszerre nemcsak a kerületek választópolgárainak területi elhelyezkedése és azok politikai véleménye hat jelentősen, hanem a választók távolmaradása, a harmadik vagy egyéb pártra leadott voksoknak és azok szerzett egyéni mandátumainak hatásai is. Ezek a folyamatok szintén markánsan alakítják a földrajzi torzulások természetét, amit együttesen reactive malapportionmentnek nevez az elméleti modell (JOHNSTON, R. 2002a). Tehát ebben az értelmezésben a földrajzi torzulásokba beletartozik mindhárom imént említett tényező, ami jelentős területi hatást gyakorol. Így a hatások összetettsége miatt ezen fogalmakat és szerteágazó elméleti megközelítéseiket később különkülön alfejezetben is kifejtem majd.

A földrajzi torzulások JOHNSTON (2002a) szerinti elméleti értelmezéséhez ALTMAN (2002), ERIKSON (2002), valamint MOORE (2002) is megjegyzéseket, kiegészítéseket füz. Ezeket föként a többségi választási rendszerben tapasztalható egyéni választókerületi rendszerre és annak földrajzi hatásaira lehet értelmezni. Komolyabb polémia alakult ki a szakirodalomban és megoszlottak a vélemények a gerrymandering résztényező elméleti értelmezésénél és a győzteskompenzáció kérdésében is. JOHNSTON (2002 a, b) amellett érvel, hogy a kompenzáció igazságos, hiszen a győztesre leadott voksok azon része, ami közvetlenül egyéni mandátumot nem eredményez, elveszne és növelné a gerrymandering hatását. Tehát az elpazarolt szavazatok mellett a második helyezett jelölt szavazatszáma plusz egy voks feletti részt javasolja a győztesek kompenzációjára, hiszen ezzel csökkenthető a földrajzi torzuláson belüli gerrymandering mértéke (JOHNSTON, R. 2002b).

Az iménti érveléssel szemben MOORE (2002) szerint igazságosabb lenne, ha a mandátumot szerzett képviselőnek juttatott győzteskompenzáció a szavazatok 50 százalék és plusz egy szavazat felett járna. Ez csökkentené a választási rendszer általános aránytalanságát is, mindemellett azért is fontos, mert a legitimitás miatt meg kell követelni, hogy a befutó jelölt szerezze meg a leadott voksok abszolút többségét. Kutatásom szempontjából fontos elméleti kérdés a győzteskompenzáció, hiszen a magyar választási rendszerben 2011-ben ezt újonnan vezették be. A szakirodalom feldolgozását követően úgy vélem, hogy a győzteskompenzáció részben enyhítheti a manipulatív határrajzolások hatását azzal, hogy a győztes mandátum felett is számít a voks. Azonban meglátásom szerint a hazai rendszerben is igazságosabb módosítás lehetne, ha az abszolút többség (szavazatok 50 százaléka plusz egy) feletti része kerülne győzteskompenzációra.

Összegezve az eddigi megállapításokat: a politikatudományi és földrajzi szakirodalmak alapján a választási rendszerek általános aránytalanságát célszerü elválasztani a földrajzi torzulásoktól. Amíg elméletben bizonyítottan nem hoz helyzetbe bizonyos csoportokat a földrajzi lehatárolás addig a választási rendszer földrajzi aránytalanságáról (disproportionality) beszélhetünk, ami hat a választási rendszer általános arányosságára, azonban szimmetrikus mértékben premizál mindenkit. Mivel szinte minden lehatárolás okoz valamilyen manipulációt, így érdemes földrajzi torzulásról beszélni, amit a három említett résztényező bármelyik eleme okozhat. A földrajzi torzulás tehát a választási rendszer aránytalanságának területi tényezője. Mivel a földrajzi torzulások elméleti modellje mellett azok részelemeit, úgymint malapportionment és gerrymandering külön is sokan vizsgálták, ezért az alábbi részben a földrajzi torzulások részelemeinek fogalommagyarázatát és részletes szakirodalmi áttekintését is elvégezem a JOHNSTON (2002a) féle besorolást szem előtt tartva. 


\subsubsection{Malapportionment és reactive malapportionment}

A választókerületek kialakításának egyik legtermészetesebb, többször alkotmányban is kinyilatkoztatott elve az egyenlő szavazat elve, hogy közel azonos lakosságot képviseljen egy adott képviselö. Ennek garantálása azonban időnként a gyakorlatban komoly korlátokba ütközik (ForEST, B. 2013, ONG, K.M. - KASUYA, Y. - MoRI, K. 2017, WEBSTER, G.R. 2013 a,b). Ezért a földrajzi torzulás egyik meghatározó tényezője lehet az, hogyha a választókerületek eltérő számú választópolgárral rendelkeznek. Alapvetően a döntéshozóknak törekedni kellene az egyenlő képviselet elvére, azonban a nemzetközi szakirodalomban a kerületek eltérő választópolgárral rendelkező földrajzi lehatárolását akkor nevezik „malapportionmentnek”, ha ez bizonyítottan kedvez valamilyen politikai, vagy társadalmi csoportnak (JOHNSTON, R. 1977, 2002a,b). Lényege, hogy a döntéshozó számára kedvezőtlen eredményt hozó területeken nagyméretü kerületeket vagy körzeteket hoznak létre, és ott alakítanak ki kicsiket, ahol a saját jelöltjeik jó eséllyel győznek (HAGGETT, P. 2001, 2006, PAINTER, J. - JEFFREY, A. 2009).

A témakör egyik meghatározó mintaterületén az Egyesült Államokban (LEIB, J. QUINTON, N. 2011) az 1800-as évek derekától a demográfiai folyamatok miatt folyamatosan átalakították a választókerületeket. Általános folyamat volt, hogy a vidéki területeken arányaiban egyre kevesebb választópolgár tartózkodott, míg a nagyobb városokban és urbanizált térségekben a magas népsürüség miatt nagy kerületek jöttek létre (CHEN, J. RODDEN, J. 2013). Ez olyan méreteket öltött, hogy az 1960-as évek elején néhány amerikai államban olyan kirívó volt a választókerületek közötti méretbeli különbség, hogy az igazságtalanság miatt már politikai kártyává vált a politikusok kezében. Idővel jogi precedens értékü döntések is születtek (pl. Baker kontra Carr, Bush kontra Vera, Barlett kontra Strickland stb.), ami után megpróbálták kezelni a választókerületek súlyos aránytalanságainak problémáját (WEBSTER, G.R. 2013a). Ezt idővel kezelték is, hiszen az államokon belüli kongresszusi kerületek közötti eltérések jelentősen csökkentek, és azóta a legfrissebb népszámlálási adatokat figyelembe véve folyamatosan átrajzolják azokat (HAGGETT, P. 2001, 2006, WEBSTER, G.R. 2013a).

Megállapítható az is, hogy a malaportionment mértéke nem csak térbeli beosztás kérdése, hanem a választópolgárok migrációja és demográfiai helyzete is jelentős mértékben befolyásolja. Így kijelenthető, hogy a területi aránytalanság nem statikus, hanem dinamikus, amiböl az következik, hogy a mögöttes társadalmi és demográfiai folyamatokat is szükséges értelmezni. Tehát a döntéshozatali megoldások csak időszakosan oldják meg a problémákat, hiszen a technológiai fejlődéssel és a térbeli mobilitás felerősödésével a választópolgárok számának változása egyre dinamikusabbá válhat (WEBSTER, G.R. 2013a).

A jelenség egyik oka a természetes szaporodás területi különbségeiben rejlik. Területenként eltérő mértékü a fertilitás, míg bizonyos falusias térségekben kevesebb gyermek születik, addig a szuburbanizáció által érintett amerikai nagyvárosok környékén kedvezőbbek az értékek. Másrészt a demográfiai viszonyok alakításában a gazdaságföldrajzi viszonyok (KRUGMAN, P. 1999) is közvetett módon közre játszhatnak, hiszen folyamatos, egyenlötlen belső és külső migrációt generálnak a fejletlenebb és a fejlettebb térségek között globális, regionális és lokális szinten egyaránt. Általában a belső migrációban a vidékről a városokba és azok agglomerációiba a fiatalabb, iskolázottabb társadalmi rétegek költöznek be, így változtatva a választópolgárok számát az adott területeken. Hosszabb távon, a fiatalok családalapításukkal még több szavazót generálhatnak a területen, míg a fejletlenebb térségekben elöregedő és egyre csekélyebb számú szavazó marad. Másik jelentős a malaportionmentre ható közvetett tényező a nemzetközi migráció. Míg egyrészt a fejlett 
országok dinamikus területein a bevándorlók választópolgárokká válásával idővel folyamatosan újra kell rajzolni a választókerületeket, addig a jelentős kivándorlással sújtott országok (pl. balti országok, Románia) választókerületei aránytalan zsugorodással kénytelenek szembenézni (POPESCU, M. - TÓKA, G. 2008).

$\mathrm{Az}$ is megállapítható, hogy a választókerületek választásra jogosultjainak számát nemcsak az adott államon belül kell statikus módon összehasonlítani, hanem makroszintü viszonyokba ágyazva is. Így a választókerületek méretét befolyásoló összevetések tartósan elötérbe helyezik a földrajzi lépték problémáját, amire JOHNSTON $(1979,2002 a)$ és WEBSTER (2013a,b) is részletesen rávilágít. Viszont az is megállapítható, hogy a gyakorlatban ez tovább nehezíti a választókerületek közötti arányosság betartását, hiszen ezekkel a folyamatokkal a határok kialakításánál nehéz kalkulálni. A választókerületek áttervezésénél (redistricting) az előbb tárgyalt problémára megoldást nyújthat a technológiai fejlődés és az informatikai algoritmusokkal történő határrajzolás (HAGGETT, P. 2001, 2006).

Ezen felül a földrajzi torzulások elemzésénél nem elég csak arra figyelni, hogy a kerületekben közel azonos számú választásra jogosult állampolgár legyen, hiszen a választási részvétel is jelentősen befolyásolja a mandátumok kiosztását és a szavazatok számát. Szélsőséges esetben a hagyományos torzulást elfedheti, vagy jelentősen felerősítheti a szavazók távolmaradása, ami végső soron a mandátumkiosztást is befolyásolja. Ebböl az következik, hogy a földrajzi torzulások másik jelentős tényezője a reactive malapportionment, amit a szavazói távolmaradásokkal (abstentions), fordított esetben a részvétellel lehet kifejezni. Mivel többnyire az iskolázottabb, urbánusabb, fejlettebb országrészekben magasabb a választási aktivitás (Bódi F. - BóDi M. 2011, KovÁcs Z. 2000, VIDA Gy. 2013, 2014, 2016), így a különbséget okozó két fö ok (a választópolgárok számának és a részvételi aránynak a különbsége) együtt jelentkezik, így felerősített területi aránytalanság is megfigyelhető a választási rendszerekben. Ezért felül kell vizsgálni bizonyos idöközönként a választási kerületeket és a módosítások közben ezekre a szempontokra is hangsúlyt kell helyezni. Ebből következik, hogy a tényezők redukálása más megvalósítható elvi kritériumok figyelmen kívül hagyásával is járhat, amit a későbbiekben bővebben kifejtek (WEBSTER, G.R. 2013a,b).

$\mathrm{Az}$ előző folyamatokon túlmenően kijelenthető, hogy a kisebb pártokra, föként a parlamentbe be nem jutott pártokra leadott szavazatok többnyire elvesznek és nem számítódnak bele a mandátumkiosztásba. Ezért JOHNSTON (2002a) szerint ez is hatással van az aránytalanságra és figyelembe kell venni ezt is a torzulások értelmezésénél. Fontos megállapítani, hogy az angolszász, föként amerikai és angol választási rendszerekben mivel nincs egyáltalán kompenzáció, ezért a kispártokra leadott képviselői helyet nem eredményező voksok is elvesznek. Azonban Magyarországra ezt megkötésekkel érdemes használni, hiszen 1990 óta töredékszavazat kiosztás is található a rendszerünkben. Így célszerü a hazai viszonylatokban a parlamentbe be nem jutott pártokra leadott voksokat is értelmezni a reactive malapportionment résztényezőjének. Ez abból adódik, hogy a törvényhozásba bejutó pártokra leadott voks már ér valamennyit, és ez közvetlen módon hat a mandátumok kiosztására.

A teljesen elveszett voksok ugyanakkor jelentősen súlyozhatják a kerületek választásra jogosultjainak eltéréseit és a részvétel által kialakított területi eltéréseket is. Ha egy nagyobb választókerületben magasabb a részvétel, viszont sok szavazatot kap olyan párt vagy jelölt, amik nem számítanak a mandátumok kiosztásba, az hasonló, mintha alacsonyabb részvétellel nem volna ilyen elpazarolt voks. Magyarországi viszonyokat tekintve általában az urbánusabb területeken viszonylag sok parlamentbe be nem jutott formációkra leadott voks veszik el (VIDA GY. - KovÁCs Z. 2017, VIDA GY. - KovALCSIK T. 2018) ami csökkenti a részvételből adódó korábban kifejtett jelentősebb eltéréseket. A hatótényezők ezen részterületei ugyanakkor már szorosan összefüggenek a választókerületek eredményorientált megrajzolásával is, hiszen a folyamatok leírásánál a politikai pártok szavazóbázisának térbeli eloszlását is lehet elemezni. 
Így a pártok szavazóbázisának eloszlása már elvezet minket a gerrymandering elméleti vizsgálatához.

\subsubsection{Gerrymandering}

A választások földrajzi torzulásainak befolyásolására az előző fejezetben kifejtett területi aránytalanság hatásán kívül egyéb eszközöket is lehet alkalmazni. A választási földrajz egyik meghatározó szegmense a választókerületek konkrét manipulatív meghúzásának, illetve az eredményekre gyakorolt hatásának a vizsgálata. Ezen jelenségek gyüjtőfogalma a gerrymandering. Klasszikus példa erre a névadó Elbridge Gerry kormányzó esete, aki feltünő karéj alakú területeket határolt le annak érdekében, hogy biztosan ő nyerje a választásokat (HAGGetT, P. 2006, MARTis, K. 2008).

A szakirodalom alapján általában gerrymandering fogalmának tekintjük az olyan eredményorientált választókerületi beosztást, vagy határrajzolást, ami szándékosan helyzetbe hoz, vagy hátrányba juttat valamilyen politikai pártot, társadalmi csoportot vagy személyt (HAGGETT, P. 2006, MoRILL, R. 2009). Fontos megjegyezni, hogy a szakirodalomban jelentős eltérések vannak a fogalomhasználatban. A gerrymandering fogalmába néhol (KAVANAGH, A. 2009) beleértik a választókerületek eltérö méretezését is, holott ezt a jelenséget a foáramlatú szakirodalomban malapportionmentként tartja számon. A fogalmak ilyen szintű összemosása nem szerencsés, hiszen más témakörökhöz hasonlóan a ez gázolja a tudományos kutatásokat.

A gyakorlatában általában két fő szélsőséges esettel találkozunk. Az egyik módszer a tökéletesen homogén választókerületek (stacked gerrymandering) kialakítása, ahol az ellenfél a szokásosnál nagyobb mértékben győz, de a többi kerületben viszont vereséget szenved. A másik lehetséges módszer, hogy a kerületeket úgy alakítják ki, hogy a másik párt szavazótábora lehetőleg szétszóródjon, és így a riválisok egyik mandátumot sem tudják elhozni (craced gerrymandering) (JOHNSON, R. 2002a, MORILL, R. 2009).

A két hagyományos típus mellett lehet manipulálni például úgy is, hogy ahol erősebb az egyik párt ott a rendszer az országgyülési kerületből több parlamenti képviselőt juttat be a törvényhozásba, míg a másik helyen csak egyet (MORILL, R. 2009). Erre akkor nyílik lehetőség, ha a választási rendszer megengedi a több képviselős választókerületeket (multimember districts). Mindemellett úgy is lehet eredményorientáltan manipulálni, ha az ellenfél térben egymástól távol lévő támogatóinak koncentrált részcsoportjait elhelyezem egy általam biztosan felügyelt kerületbe (MORILL, R. 2009). Így lehetséges a másik oldal szavazóinak térbeli megosztása úgy, hogy jelöltállításnál erősíti a rivalizálást az ellenfél táborán belül. Ez végeredményben kedvez a manipulátornak, hiszen az ellenfelek kiválasztanak egy jelöltet valamelyik helyről, amire az ott élők szívesebben voksolnak, míg a többi szegregált csoport választói magatartása átlagon aluli lesz, mivel azt gondolják, őket nem képviseli megfelelően

az adott jelölt. Így a manipulátor pártja átlagos eredménnyel elnyerheti a kerületet. Ez utóbbi lehetőséget leginkább az etnikai kisebbségek kiszorítására alkalmazták az Egyesült Államokban (MORILL, R. 2009).

Tehát több lehetséges módja létezik a gerrymanderingnek, és a JOHNSTON (2002a) féle értelmezésen túlmenően a kutatások nemzetközi példáiban a politikai pártokat helyzetbe hozó választókerületi manipuláció (partisan gerrymandering) mellett az etnikai kisebbégek kiszorítását eredményező határrajzolásokat (racial gerrymandering) is megkülönböztetnek. Így a többségi választási rendszer sajátosságaiból és a földrajzi tudományos feldolgozások területi pozícionálásából adódóan föként az angolszász országokban találhatunk illusztris eseteket etnikai csoportokat és pártokat is helyzetbe hozó választókerületi manipulációra. Például az 
Egyesült Államok kongresszusi választásain a republikánus és demokrata szimpátiával rendelkező kerületek manipulálása rendszeresen központi kérdéskör, így ezeknek az eseteknek széles nemzetközi irodalma van (LEIB, J. - QUINTON, N. 2011, PAINTER, J. - JEFFREY, A. 2009).

Az etnikai alapú manipulációra példa, hogy általában a fekete többségü területeken olyan választókerületeket hoztak létre, ahol a területhez úgy kapcsoltak fehérek által lakott térségeket, hogy mindenhol a fehérek legyenek többségben (WEBSTER, G. R. - QUINTON N. 2010). A fekete kisebbség így kiszorult a törvényalkotásból, holott az adott területen fele-fele arányban éltek a fehérekkel. A manipuláció extrém formái is kialakultak, mivel bevett gyakorlat volt a spanyol ajkúak kiszorítása is. Törekedtek a törvényhozók az etnikai kisebbségek képviseltét minimálisra szorítani a törvényhozásban (WEBSTER, G. R. - QUINTON N. 2010). Továbbá jellemző még kisebb földrajzi léptéken urbánus vagy rurális térségeket helyzetbe hozó manipulációról beszélni, ahol úgy húzzák meg a határokat, hogy egyik vagy másik közösségnek nagyobb érdekérvényesítő ereje legyen a magasabb területi szintü törvényhozásban (MORILL, R. 2009, WEBSTER, G. R. 2013a).

A választási manipuláció meglétét számos módon értelmezik, ezért azt is célszerü megjegyezni, hogy a választókerületek földrajzi formájának a vizsgálatával is ki lehet a mutatni a torzulásokat, hiszen, ha az adott választókerület a körülményekhez képest sokkal kevésbé kompakt, akkor feltételezhetö, hogy ott egyéb társadalmi jelenséget (pl. etnikai, vallási vagy politikai hovatartozást) is figyelembe vettek a választókerület rajzolásakor (GILLMAN, R. 2002). Ez ugyanúgy kimeríti a választási manipuláció fogalmát. Ebből adódóan a kerületek alakjának az egyik legszélesebb körben elfogadott és alkalmazott mérési módszere a kompaktság (KovAlcsiK, T. et al. 2019), aminek elméleti megközelítését ALTMAN (1995) már részletesen kifejtette. A kerületek tervezésénél a kompaktsági tényező kiemelése ugyanakkor más kritériumok figyelmen kívül hagyásával is járhat (QUINTON, N. 2013, WEBSTER, G. R. 2013a, b). Továbbá a választási részvétel is jelentősen befolyásolja a mandátumok kiosztását és a lakosok szavazatainak valódi értékét. Ezért meglátásom szerint a választókerületek kompaktságának elemzése ugyan közelebb vihet a gerrymandering kimutatásához (KovALCSIK T. et al. 2018, 2019), de csak egy szempont lehet a választási rendszerek földrajzi torzulásainak vizsgálatában.

Általában a gerrymandering jelenségét és értelmezését a többségi választási rendszerekhez szokták kapcsolni, azonban minden típusban megjelenik, olykor jelentősebb méreteket öltve. Erre bizonyíték, hogy COMA és LAGO (2016) regressziós módszerrel 54 demokratikus országot összehasonlítva vizsgálta a gerrymandering mértékét és ennek összefüggéseit az országok politikai berendezkedésével és gazdasági fejlettségével. Kiemelhető, hogy nincs szignifikáns kapcsolat a választási rendszer berendezésének időbelisége, a gazdasági fejlettség és a gerrymandering mértéke között (COMA, F. M. - LAGO, I. 2016), ami arra utal, hogy a fejlettnek mondott demokráciákban is lehet nagy manipuláció. Továbbá az is megállapítható, hogy a választási rendszereket összevetve átlagosan a legnagyobb mértékü torzulás a többségiben van, majd ezt követi a vegyes és végül az arányos szisztéma. Ha az esetek szórását nézzük akkor fontos megjegyezni, hogy erre a torzulási folyamatra a pártrendszer is jelentős hatással van, így az általános tendenciák mellett a szélsőértékek elemzésével tapasztalható volt az, hogy néhány esetben a többségi rendszerek jobban teljesítettek, mint a vegyesek.

Összegezve az eddigieket kijelenthető, hogy a gerrymandering széles körben vizsgált témakör, és sokféleképp lehet manipulálni a választókerületek határaival. A legtöbb nemzetközi példát a választási földrajz angolszász dominanciája miatt is ezekben az országokban találjuk. Azonban érdemes kiemelni, hogy a választási manipuláció ilyen formája minden típusú választási rendszerben jelentkezhet, ahol valamilyen területi felosztást alkalmaznak és ez nincs összefüggésben sem az ország helyzetével, sem a demokratikus hagyományaival. 


\subsection{A választókerületek kialakításának kritikai és posztstrukturalista megközelítései}

A választási földrajzi torzulások kutatásában eddig döntően pozitivista és strukturalista megközelítésekkel találkoztunk és ennek területi elemzései dominálták a témakör publikációit (PATtie, C. - Johnston, R. 2009). Azonban az utóbbi évtizedekben a földrajzon belül és a választásokat elemző kutatásokban is megjelentek a kritikai politikai gazdaságtani perspektívák (NICLEY, E. P. 2011), vagy posztstrukturalista megközelítések (LEIB, J. - WEBSTER, G. R. 2009). Ezek az társadalomelméleti irányzatok a földrajz egyéb területei (BoROS L. 2012) mellett magukba foglalják a határok létrehozásának tágabb értelmezését, a hatalmi viszonyok és az identitások társadalmi meghatározottságának vizsgálatát a választókerületek tervezésénél (LEIB, J. - WeBSTER, G. R. 2009). A kritikai és posztstrukturalista irányzatok a pozitivista választási földrajzos elméletekhez képest a társadalmi igazságosság felől közelítik meg a területi sajátosságokat (RAWLS, J. 1971, 1997, VICKREY, W. 1961). A választókerületek áttervezésének folyamatát, a földrajzi torzulásokat és azok részelemeit a politikai reprezentáció és a participáció kérdésköre felől közelítik meg (FOREST, B. 2009). Fontos megállapítani, hogy a participáció fogalma nem azonos a választási részvétellel, hanem annál tágabb fogalom, hiszen magában foglalja a lakosság cselekvő bekapcsolódását a politikába és a döntéshozatalba is (SEN, A. 2003). Igy célszerü először a társadalmi igazságosság témakörhöz köthető alaptéziseit meghatározni, majd a választókerületek erre épülö átrajzolásának földrajzi elméleteit kifejteni.

A választási participáció filozófiai alapelméletében RAWLS (1971) kifejti, hogy a politikai igazságosság a szabadság és a részvétel elvén alapul. Az elöbbi az alkotmányban lefektetett alapvető emberi jogokat, valamint ennek gyakorlatát jelenti, míg a szabadság elve főként az emberek politikába való beleszólását jelenti. Érvelése szerint az egyenlő szabadság és részvétel feltétele, hogy nagyjából azonos számú embert képviseljen egy adott képviselő (YouNG, I. 1990). Elgondolásában azt feltételezi, hogy a választókerületeket a lehető legpártatlanabb eljárás szerint kell kialakítani. E nélkül nem lehet elejét venni a választási csalásoknak, hiszen ezek befolyásolják a szavazatok súlyát és a végeredményt is.

SEN (2003) továbbfejleszti és kiterjeszti RAWLS $(1971,1997)$ gondolatait és a fejlődés és szabadság kiterjesztett értelmezésére tesz kísérletet. Ennek során rámutat a szabadság és participáció öt általa fontosnak tartott résztényezőjére és erre elméleti keretet is meghatároz: (1) politikai szabadságjogok, (2) gazdasági feltételek, (3) szociális lehetőségek, (4) transzparencia, valamint (5) létbiztonság (SEN, A. 2003, BАJMÓcY Z. 2011). Elméleti megközelítésében az állampolgárok valódi vélemény-nyilvánításán alapuló demokrácia előnyei mellett érvel. A választási rendszerek a véleménynyilvánítás információs kereteit lényegesen leegyszerüsítik. A választásokon a szavazó leteszi a voksát egy párt vagy jelölt mellett, amivel támogatja a következő ciklusra, azonban ez nem jelenti automatikusan azt, hogy a polgár feltétel nélkül egyetért az általa megszavazott párt vagy jelölt összes döntésével vagy véleményével (BAJMócy Z. 2011). Így megállapítható, hogy a valódi szélesebb politikai részvételt a rendszeres népszavazással, vagy az állampolgárok aktív cselekvő bevonásával lehet elérni lokális és országos léptékben egyaránt (FERENCZ Z. 2015, NEWMAN, P. - JENNINGS, I. 2008). Ugyanakkor a gyakorlatban egy teljesen igazságos rendszert szinte lehetetlen létrehozni, mivel a választókerületeket meghatározó szempontok egymásnak is ellent mondanak (WeBSTER, G. R. 2013a, b). Továbbá a politikai hatalom gyakorlóinak nem érdeke az, hogy szélesebb beleszólást adjunk az állampolgároknak, hiszen a jelenlegi választási rendszerek konzerválják a pártrendszert és a hatalmi relációkat is, így nem áll érdekükben annak megváltoztatása. 
A társadalmi igazságosság elméleti rendszere a politikai földrajzra, így a választókerületek térfelosztási kérdéseinek értelmezésére is hatással voltak (LEIB, J. WEBSTER, G. R. 2009). Erre utal az is, hogy a választásokkal kapcsolatos földrajzos kutatásokban a brit JOHNSTON (1979) gazdasági elméletekből kiindulva feltételezte, hogy elsődlegesen a hatalmi és hivatali pozíciókért való küzdelem határozza meg a politikusok, képviselők céljait, s a társadalmi tevékenység csak másodlagos jelentőséggel bír. Ennek a gondolatnak továbbfejlesztett változata a Down- és Herder-Dorneich-modell. Két alapvetése van, amiből az egyik lényege, hogy a pártok megfogalmazzák céljaikat, hogy megnyerjék a választásokat, de nem azért nyernek, mert céljaik a lakosság érdekeinek megfelelnek. A másik tétel azt mondja, hogy a választásokat az a párt vagy oldal nyeri, amelyik több előnyt ígér, mint a másik (MEZÖ F. 2003). Ez utóbbi nem minden esetben állja meg a helyét, ugyanis a választók pártpreferenciáit más tényezők is befolyásolják, például napjainkban a média és azon belül a közösségi média hatása is egyre erősebb (BAYER J. 2000, BÁNYÁSZ P. 2019, BENE M. 2018). Azonban a Down- és Herder-Dorneich-modell világosan rávilágít arra, hogy a döntéshozók hatalmi privilégiumaik megtartására törekednek és a választópolgárok megnyerése ebben csak eszköz.

Az előző gondolatmenetből következik, hogy WEBSTER (2013b) szerint viszonylagos fogalom az igazságosság, valamint az állampolgári jogoknak az érvényesítése és erényei a gyakorlatban termelődnek ki, ahol a hátrányok és előnyök mérlegelésére kell fektetni a hangsúlyt. Ebből adódóan a társadalmi igazságosság és a gyakorlati alkalmazások felől közelítve a választókerületek tervezésénél hét fö kritériumot sorakoztat fel. Amerikai példákon szemléltetve a választókerületi beosztás vizsgálatánál legelsőnek fontossá vált az egyenlő népesség (equal population), az etnikai diverzitás (racial equity) és a szomszédosság (contiguity) kritériuma (HAGGETT, P. 2006). Később a 2000-es évekre azonban az igazságos választókerületek megalkotásához a hagyományosnak mondható kritériumok mellett új elvek is felmerültek. Így a választókerületek igazságos áttervezéséhez szükséges a politikai szubkultúrák megőrzése (preservation of political subdivisions), a kerületek földrajzi kompaktságának (compactness) garantálása, az azonos érdekeltségű csoportok védelme (protection of communites of interest) és a jogfolytonosság miatt a korábbi beosztás központjainak megtartása (incumbent protection/preservation of the core of previous districts) is (WEBSTER, G.R. 2013a,b).

Megállapítható, hogy a gyakorlatban kialakult kerületrajzolási elvek politikailag konstruált, szinte kőbe vésett feltételek mentén alakulnak, azonban ezek sokszor egymás ellen dolgoznak, sőt a fogalmak értelmezése is rugalmasabb, mint amilyennek tünik (QUINTON, N. 2013). Erre világít rá FOREST (2013) azzal, hogy szerinte a választókerületi gyakorlat túl fontosnak tartja az egyenlő lakosság, a szomszédosság és a kompaktság kritériumát, és túlságosan elötérbe helyezi a fizikai földrajzi közelséget. Ebböl az következik, hogy nem veszik kellőképpen figyelembe a kapcsolati, a társadalmi és a politikai közelséget, ami a belső és külső objektív tér különbségéböl (NEMES NAGY J. 1998, 2009), valamint annak eltéréseiböl adódik. Szerinte fel lehetne úgy is osztani a választókerületeket, hogy kapcsolati, gazdasági és társadalmi tulajdonságok alapján is hasonló területeket vonjanak össze. Ezek a kerületek nem lennének feltétlenül kompaktak és szomszédosok, ami nem jelentené azt, hogy igazságtalanabb lenne ez a megoldás, hiszen egyszerüsödne a képviselet olyan szempontból, hogy közel azonos politikai ügyeket kellene képviselni és megoldani (FOREST, B. 2013). Ez a szemlélet álláspontom szerint a gyakorlatban felerősítené a város-vidék ellentétet (WALKS, R. A. 2004, 2005, 2006) és a társadalom összekapcsolásának esélyeit, és tovább mélyítené a szavazói csoportok polarizációját és a gerrymandering itt is felmerülhetne.

További nagy elméleti dilemma a társadalmi igazságosság szempontjából az is, hogy miként oldjuk meg választókerületeken belül a politikai szubkultúrák megőrzését és az azonos érdeklődésü csoportok védelmét. Ugyanis, ha túl kevert politikai és társadalmi szerkezetü 
kerületeket hozunk létre, akkor a politikai kompromisszum kialakítása nehezebb lesz és kérdés, hogy a vita mennyire tereli el a figyelmet a döntéshozatal hatékonyságáról. Ha viszont földrajzi szempontból homogénebb területeket határolunk le, akkor felmerülhet a gerrymandering a döntéshozásban (FOREST, B. 2013). Ez a kérdéskör összefügg a már korábban kifejtett választási manipuláció kifinomultabb formáival is, amikor a kerületen belül kialakítunk hasonló tulajdonságú szegregált területeket és ezzel elősegítjük a politikai széttartást (LEIB, J. WEBSTER, G. R. 2009).

Az előző gondolatmenetet folytatva meghatározható, hogy jelentős diszkrepancia van az etnikai diverzitás garantálása és az azonos érdekcsoportok védelme között is. FoREST (2013) és QUINTON (2013) amellett érvel, hogy egyrészt, ha az etnikai kisebbség döntően egy tömbben szegregált a térben, akkor be lehet osztani egy homogén választókerületbe. Ez politikai szempontból az Egyesült Államokban azt hozta, hogy kialakultak nagyon liberális demokraták és nagyon konzervatív republikánusok egymás melletti kerületekben, ami későbbiekben a döntéshozásban a kompromisszum lehetőségét teljesen kiiktatta. Másrészt, ha földrajzilag a térben két egymástól távolabb lévő tömbben koncentrálódnak a kisebbségi csoportok, akkor szinte lehetetlen beosztani az említett elvek szerint igazságosan a kerületeket, hiszen összeütközés alakul ki az egyenlő népesség és kompaktság, valamint a szomszédosság kritériumaival. Ebből adódóan az is kijelenthető, hogy ha az egyenlő lakosság elvét nagyon szigorúan vesszük, akkor az teljesen fölülírja a többi kritériumot. Emellett nem számol a gyakorlat azzal, hogy a részvétel jelentősen eltér a kerületek között, így abban az esetben, ha a malapportionmentet szigorúan ki is iktatjuk a rendszerböl, a reactive malapportionment még okozhat jelentős földrajzi torzulásokat.

Az előző bekezdésekben felhozott dilemmákra reflektálva WEBSTER (2013b) megjegyezte, hogy sok kritikai földrajzi elmélet csak a társadalmi konfliktusokat emeli ki és ennek igazságtalan térbeli eloszlását hangsúlyozza, ami meglátása szerint túl szük keresztmetszet. Ezt az is alátámasztja, hogy a választókerületek beosztásánál kialakult egyenlőtlenségek abból is eredhetnek, hogy az eltérő pártpreferenciával rendelkező választók térben nem egyenletesen oszlanak meg a települések között és azokon belül sem (CHEN, J. RoDDEN, J. 2013). Ebböl az is következik, hogy akaratlanul is kialakulnak sajátos formájú választókerületek és földrajzi torzulás is automatikusan kialakul. Mindemellett a választókerületek igazságosságának elemzésénél kevésbé veszik figyelembe, hogy a választók bizony aktív szereplői is a folyamatnak. Erre kiváló példa a választási földrajzban kutatott szomszédsági hatás (AGNEW, J. 1996), miszerint a polgárok szívesebben voksolnak a földijükre, vagy az adott térben koncentráltan artikulált többségi véleményt pszichológiai okokból idővel a kisebbség is vallani fogja (PATtie, C. - Johnston, R. 2009). Ez a folyamat véleményem szerint kiélezi a társadalmi törésvonalakat (LIPSET, S. M. - ROKKAN, S. 1967, INGLEHART, R. 1977), földrajzilag meghatározza azokat és ezzel jelentős hatással van a gerrymandering jelenségre is.

Mindenesetre a technológia fejlődésével és a földrajzi információs rendszerek térhódításával minden eddiginél könnyebbé vált a választókerületek kialakításának statisztikai felosztása és azok követése is. Például az Egyesült Államokban tömbszintủ népszámlálási adatokat biztosítanak a kerületrajzolók számára, amivel igazságosabb beosztásokat lehet létrehozni. Azonban a bőséges adatbázis és a geoinformatikai modellek a választási manipulációnak is a legszofisztikáltabb módjait hívták életére (LEIB, J. - WEBSTER, G. R. 2009). Mindemellett a kifinomult geoinformatikai módszerekkel megtámogatott kvantitatív térfelosztásnak is van jelentős kritikája. FOREST (2013) azt állítja, hogy a kerületek meghatározásához a társadalmi statisztikai adatokon alapuló kerületbeosztás sem mindig előnyös, hiszen az elfedhet bizonyos társadalomföldrajzi háttérfolyamatokat. Ezek a háttérfolyamatok befolyásolják a döntéseket és az elvek valódi érvényesülését, hiszen az 
iskolázottsági, jövedelmi, demográfiai adatokból kialakított hasonló klaszterekben az egyének sem viselkednek ugyanúgy és döntéseik mögöttes motivációja is jelentően eltér.

További kihívás a választókerületek megrajzolásánál és annak tudományos elemzésénél az ún. „Modifiable Areal Unit Problem” (MAUP) kérdésköre (TAYLOR, P. J. - OPENSHAW, S. 1979, Openshaw, S. 1984, AGNEW, J. 1996, Johnston, R. 2001), azaz ugyanaz a jelenség az eltérő földrajzi lehatárolásokból eredően eltérő térbeli mintázatot mutat. A kritikai irányzatokból táplálkozva a fóáramlatú módszertani elemzéseknél is felmerül, hogy az objektív külső térfelosztási szempontok mellett figyelembe kellene venni egyéb mögöttes társadalmi tényezőket is. Például a demográfiai és migrációs folyamatok következtében az egyre nagyobb területi különbségek idővel újratermelődnek (FOREST, B. 2013, VIDA GY. - KOVALCSIK Z. 2018). Tehát az egész térfelosztási problémakör változó, amit nehéz modellezni, de törekedni kell rá.

A kritikai és posztstrukturalista szakirodalmakat összegezve megállapítható, hogy a társadalmi igazságosság vizsgálata végletekig szubjektív és az objektívnak tünő geoinformatikai modellezések is folyamatosan újratermelnek választási földrajzi igazságtalanságokat. A hagyományos elemzéseken túlmenően hét elméleti kritériumot határoztak meg, ami szerint szükséges lenne a választókerületek megrajzolása. Azonban a kritériumok összeegyeztethetetlenek és a társadalom folyamatos változásából kifolyólag nehéz objektív képet alkotni, hiszen a kutató egyéni irányultsága, szubjektivitása is jelentően befolyásolja az eredményeket.

Meglátásom szerint a választókerületek tervezésének folyamatában felmerülő elméleti kritikák és alternatív megközelítések rámutattak arra, hogy a statisztikai alapokon átrajzolt határok sem jelentik automatikusan azt, hogy igazságosabb területi felosztást kapunk. Az ilyen koncepciók létrejötte és ütköztetése bizonyíték arra, hogy a választókerületek áttervezése és a földrajzi torzulások elemzése nemzetközi szinten egyre fontosabbá válik. Azonban szükség van egy fontossági sorrendet felállítani a választókerületek megrajzolásánál, amin keresztül értelmezzük a lezajlott földrajzi folyamatokat. Szakmai meglátásom szerint a földrajzi torzulások elkerülésénél a magyarországi mintaterületen kulcsfontosságú a választókerületek méretének azonossága, a szomszédság és kompaktság szerepe, valamint a homogén és

heterogén területek pontos meghatározása. A disszertáció gyakorlati javaslatait is erre az általam kialakított kritériumrendszerre alapozom majd.

\subsection{Választási földrajzi torzulások posztszocialista és magyarországi megközelítésben}

A nemzetközi, föként angolszász választási földrajzban felmerülő elméleti dilemmákat követően célszerü megvizsgálni, hogy a földrajzi torzulások és egyes elemeinek vizsgálata hogyan jelent meg a posztszocialista térség, és azon belül a hazai szakirodalomban, hiszen ebben a témában az utóbbi évtizedekben a környezö országokban is született több tanulmány (KowALSKI, M. 1999, LEIB, J. - QUINTON, N. 2011). Fontos történelmi mérföldkő volt, hogy Kelet-Közép-Európa volt szocialista országai a Szovjetunió összeomlását követően visszanyerték politikai szuverenitásukat, és időközönként ismét demokratikus választásokat tarthattak. Ezek az országok az 1990-es években különböző választási rendszereket honosítottak meg (4. táblázat), s a sokszínüség magával hozta a térség választási rendszereinek elemzését (BALOGH, L. 2012, BIRCH, S. et al. 2002, FÁBIÁn GY. 2017, ISHIYAMA, J. T. 1997). 
A környező országokban, például Csehország alsó házában, Szlovákiában, Romániában, Szlovéniában jellemző a listás választási rendszer, míg Litvánia és Magyarország vegyes szisztémája szinte kivételnek számít a térségben (BRICH, S. et al. 2002, ISHIYAMA, J. T. 1997). Kiolvasható az adatokból, hogy - néhány országot leszámítva - a listás keretrendszerekben is többnyire többmandátumos választókerületekben aggregálják a voksokat és van olyan ország is, ahol jelölteket is lehet változtatni ezeken a listákon (BALOGH L. 2012). Ennek ellenére azonban a témakörhöz kapcsolható szakirodalom áttekintése után megállapítható (BALOGH L. 2012, BRICH, S. et al. 2002, ISHIYAMA, J. T. 1997), hogy a nyugati államokhoz képest a posztszocialista országokban a választókerületi beosztások konkrét földrajzi torzulásainak vizsgálatával kevésbé foglalkoztak, így ez a kérdéskör hazánkban is marginálisnak mondható.

4. táblázat: Néhány posztszocialista ország választási rendszerének főbb tulajdonságai 2017-ben

\begin{tabular}{|c|c|c|c|c|c|}
\hline Országok & $\begin{array}{c}\text { Választási rendszer } \\
\text { fötípusa }\end{array}$ & $\begin{array}{l}\text { Képviselők } \\
\text { száma }\end{array}$ & $\begin{array}{c}\text { Egyéni } \\
\text { választókerületek } \\
\text { száma }\end{array}$ & $\begin{array}{c}\text { Listás } \\
\text { választókerületek } \\
\text { száma }\end{array}$ & $\begin{array}{c}\text { Egy } \\
\text { mandátumra } \\
\text { jutó lakosok } \\
\text { száma 2017- } \\
\text { ben ( foo) }\end{array}$ \\
\hline Albánia & $\begin{array}{l}\text { Többmandátumos } \\
\text { választókerületekre } \\
\text { épülő arányos }\end{array}$ & 140 & 0 & 12 & 20521 \\
\hline Bulgária & $\begin{array}{l}\text { Többmandátumos } \\
\text { választókerületekre } \\
\text { épülő arányos }\end{array}$ & 240 & 0 & 31 & 29592 \\
\hline Csehország & $\begin{array}{c}\text { Többmandátumos } \\
\text { választókerületekre } \\
\text { épülő arányos }\end{array}$ & 200 & 0 & 14 & 52900 \\
\hline Észtország & $\begin{array}{l}\text { Többmandátumos } \\
\text { választókerületekre } \\
\text { épülö arányos }\end{array}$ & 101 & 0 & 12 & 13030 \\
\hline Lettország & $\begin{array}{l}\text { Többmandátumos } \\
\text { választókerületekre } \\
\text { épülö arányos }\end{array}$ & 100 & 0 & 5 & 19500 \\
\hline Litvánia & Vegyes & 141 & 71 & 70 & 20199 \\
\hline Lengyelország & $\begin{array}{l}\text { Többmandátumos } \\
\text { választókerületekre } \\
\text { épülö arányos }\end{array}$ & 460 & 0 & 41 & 82543 \\
\hline Magyarország & Vegyes & 199 & 106 & 1 & 49138 \\
\hline Románia & $\begin{array}{c}\text { Többmandátumos } \\
\text { választókerületekre } \\
\text { épülő arányos }\end{array}$ & 329 & 0 & 43 & 59696 \\
\hline Szerbia & Arányos & 150 & 0 & 1 & 46813 \\
\hline Szlovákia & Arányos & 150 & 0 & 1 & 36233 \\
\hline Szlovénia & Arányos & 90 & 0 & 1 & 22956 \\
\hline
\end{tabular}

Forrás: BALOGH L. 2012 és ahttp://www.parties-and-elections.eu/countries.html honlap alapján saját szerkesztés 
Ennek az oka, hogy közvetlenül a rendszerváltozást követően a posztszocialista országokban, politikai pártokat helyzetbe hozó földrajzi típusú manipuláció nehezen volt megállapítható, hiszen a választókerületek megrajzolásánál az alkotók még nem tudták pontosan, milyen térbeliség jellemzi majd a választói magatartást (HAJDÚ Z. 2006). Az idő előrehaladtával több posztszocialista ország is módosított a választási rendszerén, valamint idővel kitapinthatóvá váltak a földrajzi torzulások, ezen belül főként a területi aránytalanság jelensége. Ebböl az következik, hogy tudományos szempontból is úttörő politológiai és földrajzi munkák születettek (BRICH, S. et al. 2002, GIUGAL, A. et al. 2017, POPESCU, M. - TóKA G. 2008), amiböl néhányan a földrajzi torzulásokat, úgymint a gerrymandering és a malapportionment folyamatait is kiemelték.

Megállapítható, hogy a posztszocialista országok választási rendszereiben is voltak a kerületek kialakításával kapcsolatban etikai utalások és alapkritériumok (BRICH, S. et al. 2002, POPESCU, M. -TÓKA G. 2008). Ezek az alapelvek hasonlatosak voltak a WEBSTER (2013a) által leírt általános angolszász beosztási elvekhez, mint például egyenlő népesség, földrajzi kompaktság és egybefüggő választókerületek létrehozása. POPESCU és TóKA (2008) a térség választási rendszereinek létrehozásában közremüködő jogi környezetet és elveiket elemezve meghatározta, hogy a különböző posztszocialista országokban a választókerületek közötti eltérések jogszabályban megengedett határai hogyan alakultak a 2000-es évek első évtizedében. Kutatásukból megállapítható, hogy amíg Észak-Makedóniában az országos átlaghoz képest csupán 3\%-os eltérés volt lehetséges a választókerületek méretében, addig Albániában ez 5\%ban térhet el, Fehéroroszországban, Litvániában és Ukrajnában 10\%-ot, míg Csehországban 15\%-ot is elérhetett (POPESCU, M. - TóKA, G. 2008). Ebből megállapítható, hogy a környező országokhoz képest Magyarország hatályos jogszabálya megengedőbbnek tekinthető a malapportionment vonatkozásában, hiszen ez a küszöb nálunk plusz-mínusz 15\%-os eltérést enged meg, és legvégső esetben a 20\%-os eltérésnél követel meg konkrét beavatkozást.

A gerrymandering bemutatásával korábban meghatároztuk, hogy bármilyen országosnál kisebb térfelosztásban beszélhetünk nem szándékos választási manipulációról is (CHEN, J. RODDEN, J. 2013), így ilyen folyamatok a posztszocialista térségben is kialakulhatnak. Kimutatható, hogy az 1990-es évektől számítva a környező államokban inkább az etnikai alapú közigazgatási és választási manipuláció volt jelentősebb (HALÁs, M. - KLAPKA, P. 2016, STEWART, B. 2018). Ilyen etnikai szempontból eredményorientált beavatkozásra volt példa a szlovák közigazgatási határok átrajzolása, a balti államok orosz kisebbségének képviseletét csökkentő térfelosztások, valamint Észak-Macedónia esetében is (HALÁs, M. - KLAPKA, P. 2016, STEWART, B. 2018). Mindemellett találunk politikai pártokat és csoportokat helyzetbe hozó gerrymanderingre és területi aránytalanságra is példát. A romániai választási rendszer 2008-as és 2012-es átalakításainál is bebizonyosodott, hogy a nagyobb politikai csoportok informális megállapodásokat követve úgy alakították ki a kerületeken belüli kisebb választókörzeteket, hogy stabilizálják saját pozícióikat és jelöltjeiket úgy, hogy elosztották és koncentrálták a saját szavazóikat (GIUGAL, A. et al. 2017). Ez kimondottan politikai pártokat helyzetbe hozó lépés volt és a döntéshozásban résztvevő nagyobb pártok húztak hasznot ebből, míg a létrejövő kisebb formációkat háttérbe szorította.

A posztszocialista országokkal összevetve Magyarország esetében a földrajzi torzulások markánsabban jelentek és jelennek meg, hiszen 1848-tól kezdődően előbb többségi, majd vegyes szisztémával rendelkeztünk. Ebből adódóan a választókerületek közötti eltérések a választók számában végig kísérték a demokratikus berendezkedéseinket. Magyarországon 1848-tól beszélhetünk a többségi elven müködő polgári választási rendszerről (1848. évi V. tv.). A dualizmus korában viszonylag tartós választókerületi beosztással rendelkezett az ország, de már akkor jelentős területi egyenlőtlenségek alakultak ki (CSIZMADIA A. 1963). Történeti viszonylatban 1910-re hazánkban hatványozottan jelentkezett a malapportionment, aminek okát a főváros népességének és a választásra jogosultak számának jelentős emelkedése okozta 
(HAJDÚ Z. 2006), hasonlatosan az angolszász államokhoz. Azonban ez az egyenlőtlenségi probléma akkoriban a választási földrajzi térképek illusztratív megalkotása (FODOR F. 1920, HAJDÚ Z. 1992, 2017) mellett nem képezték részletes vizsgálatok tárgyát.

Kezdetben nemi, életkori és vagyoni cenzushoz is kötötték a választójogot, ami idővel erőteljes konfliktust hozott a magyar társadalmon belül, így 1918-ban kaptak először a nők választójogot. Majd az első világháborút követő Horthy-rendszerben már a teljes lakosság közel $30 \%$-nak volt választójoga, valamint a részvétel is viszonylag magas volt (IGNÁCZ K. 2005). A modernkori Magyarországon 1920-ban tartottak első ízben viszonylag demokratikusnak mondható választásokat, azonban erősen kontrolált volt ez is (IGNÁCZ K. 2013). Megállapítható, hogy már ekkor is jelentkezett a város és vidéke közötti ellentét, amit a 1922 törvénykezés, miszerint a fövárosban és nagyobb településeken volt titkos, míg a kisebb városokban és a községekében nyílt szavazás volt - csak felerősített. A következő jelentősebb változtatás, hogy 1938-tól ismét általánosan titkos volt a voksolás, és az ajánlások rendszerét is bevezették.

A jogszabályi változások ellenére a választókerületek közötti területi eltérések nem csökkentek a trianoni határmódosítások után sem. Az 1920-as választásokon átlagosan 9721 szavazó tartozott egy kerületbe, azonban a legkisebb és legnagyobb terület között több mint húszszoros különbség volt (IGNÁCZ K. 2005). A korabeli politikai földrajz és a szakma a kérdéskört teljesen negligálta, annak ellenére, hogy mindig ábrázolták a választók számát az egyes kerületekben. Az alapvető összefüggések leírását csak később tették meg a történészek (HuBAI L. 2001a,b,c, 2018, IGNÁCz K. 2005, 2013). Ugyanakkor a választókerületek területi aránytalanságának részletes elemzése máig várat magára. A választópolgárok számának lévő területi különbségei később is fennmaradtak, és az 1938-as választójogi törvény után az egyéni mandátumok mellett megjelentek a lajstromos (listás) kerületek is, bővítve a térbeli módosító hatótényezők lehetőségeit, bár a földrajzi torzulásokkal érdemben továbbra sem foglalkoztak.

A második világháborút követően szélesedett a választásokba bevont népesség köre, ami alapvetően átformálta a helyzetet, de a politikai pluralizmus tiszavirág életünek bizonyult. $\mathrm{Az}$ 1945-ös és az 1947-es választások után a kommunista hatalomátvételt követően megszünt a demokrácia és 1990-ig nem volt érdemi relevanciája a földrajzi torzulások értelmezésének. Említést érdemel, hogy 1953-től nyílt jelöltállítás lett, aminek joga 1966-ban a Hazafias Népfront kezébe került kialakítva a kvázi egyéni kerületi rendszert. 1970-től a jelölőgyülés is állíthatott plusz jelöltet, majd 1983-tól kötelezővé vált a többes jelölés, azonban a gyakorlatban ez nem változtatott érdemben a rendszer müködésén. Ez a berendezkedés élt a demokratikus peremfeltételek megalkotásáig. Így érkeztünk el a rendszerváltozásig, amikor az új választási rendszer létrehozásában fontos tényezővé váltak az egyéni választókerületek, hiszen hazánkban ennek volt hagyománya (HAJDÚ Z. 2006). Ebből adódóan nem volt meglepetés, hogy a vegyes rendszerünkben az egyéni mandátumoknak a szerepe fajsúlyos maradt a rendszerváltozást követően is. Napjainkra a területi különbségek újra kialakultak, így ismét aktuálissá vált a választási rendszerek földrajzi hatótényezőinek vizsgálata. Azonban Magyarországon a témakör elméleti és módszertani újításainak kidolgozását nem elsősorban a geográfia vállalta magára, hanem matematikusok, politológusok, szociológusok és történészek próbálták betölteni ezt a hiátust (HubAi L. 2018, IgNÁCZ K. 2005, MÉSzÁros J. - SZAKADÁT I. 1995, 1999).

Ennek ellenére megállapítható, hogy a választási rendszerek és a választókerületi beosztás konkrét földrajzi torzulásaira nagyobb figyelmet kellene szentelni a posztszocialista országokban, így Magyarországon is. Hiszen az angolszász alapfogalmak részleges átvételén (POPESCU, M. - TÓKA G. 2008, TASNÁDI, A. 2011) és a térségben néhány úttörő (FLEINER B. et al. 2017, KovAlCSIK T. 2018) a kerületrajzolás matematikai megoldásait elemző (BIRó P. et al. 2012, KovalcsiK T. et al. 2018, 2019, KóCZY, L. Á. - SzIKLAI, B. R. 2018) munkán kívül a témakör elméleti és statisztikai szempontból még nem tekinthető megkutatottnak. 
Összegezve a posztszocialista térségben és Magyarországon a választási rendszer földrajzi torzulásainak vizsgálata nem olyan széleskörü, mint az angolszász országokban, aminek döntő oka a megkésettségre és a szocialista útfüggőségre vezethető vissza. Az utóbbi néhány évtizedben a posztszocialista térségben történtek manipulatív szándékú etnikai és politikailag eredményorientált közigazgatási és választási lehatárolások, amire találunk néhány úttörő tudományos munkát. Meglátásom szerint politikai csoportot helyzetbe hozó földrajzi torzulásra és azok elemzésére a térségben Magyarország adhat kiváló lehetőséget választási rendszeréből adódóan. Ebből az következik, hogy szükség van a posztszocialista és a hazai választási földrajz megújítására és a választási rendszerek földrajzi torzulásainak szisztematikus elméleti és módszertani vizsgálatára.

\subsection{A választási földrajzi torzulások hatótényezőinek dinamikus elméleti modellje}

A nemzetközi szakirodalmi áttekintés alapján megállapítható, hogy az elméleti kereteket az eltérō választási rendszerek és társadalomstruktúra miatt csak részben lehet alkalmazni Magyarországra, viszont adaptálásuk kísérlete kulcsfontosságú. Véleményem szerint a térbeli hatótényezők statikus ok-okozati értelmezése helyett a folyamatok közötti interakciók azok, amelyek valóban befolyásolják a földrajzi torzulások valódi természetét.

Ebből adódóan az első elméleti kutatási részkérdésemre válaszként a nemzetközi szakirodalom alapján Magyarországra vonatkozóan egy általános elméleti modellt fogalmaztam meg. Bevezetem az elgondolt és megvalósult földrajzi torzulások fogalmát és az elemek közötti kapcsolatokat is meghatározom aszerint, hogy azok hogyan formálják a választási rendszerek mandátumkiosztási gyakorlatát (3. ábra). Továbbá rendszereztem, hogy a gerrymandering, malapportionment és a reactive malapportionment kialakulására a döntéshozók mellett milyen föbb társadalmi, demográfiai és gazdasági hatótényezőket szükséges figyelembe venni.

Az elméleti modellben szükséges külön értelmezni az elgondolt, vagy látens földrajzi torzulásokat, ami az elemzés kereteit adják. Megállapítható, hogy a döntéshozók a választókerületek megalkotásával kialakítják a földrajzi keretfeltételeket. Ebből adódóan az elgondolt földrajzi torzulásokban a malapportionment azon belül a választásra jogosultak számának területi különbségei, továbbá a nagyobb közigazgatási határok mentén kialakult eltérések adják az torzulás alapját (JOHNSTON, R. 2002a,b). Ha ezt összevetem a gerrymanderinggel, vagyis a pártok támogatottságának térbeli egyenlőtlenségeivel, akkor kimutatható egyfajta elgondolt földrajzi torzulás a választási rendszerekben. Ez a megközelítés a választópolgárok térbeli elhelyezkedésének anomáliáiból, valamint a pártok támogatottságának múltbéli vagy feltételezett jövőbeli különbségeire épít. Ebből következtetni lehet a választási rendszer földrajzi hatótényezőire, azonban a konkrét hatásmechanizmusokat és összefüggéseket nem mutatja ki és a valóságban további közvetett folyamatok szerepét sem veszi figyelembe. 


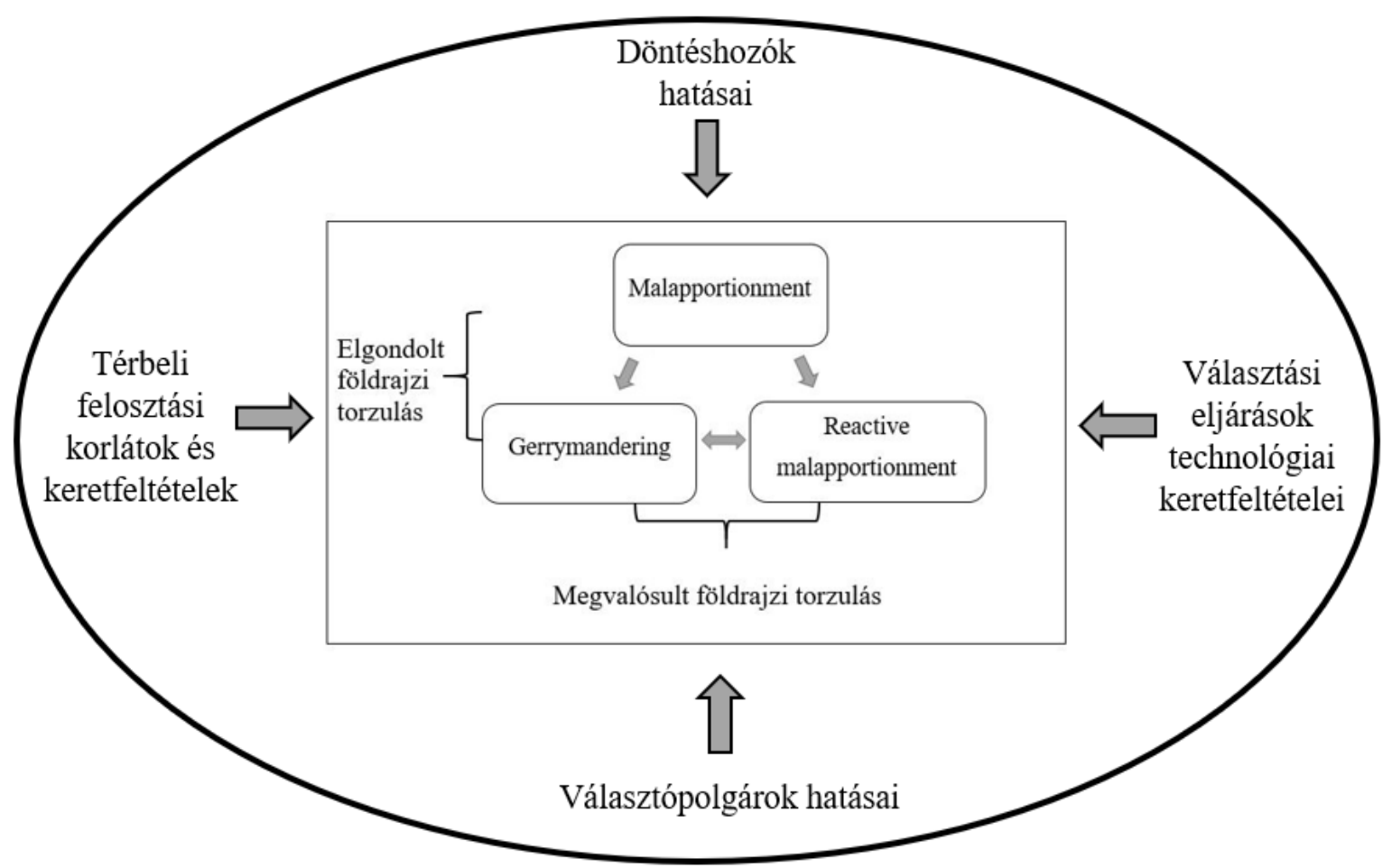

Forrás: saját szerkesztés

Ennek kiküszöbölésére érdemes bevezetni a „megvalósult földrajzi torzulás” fogalmát is, ami már döntően a reactive malapportionment és a gerrymandering közötti dinamikus interakciókon alapszik. A választókerületek választásra jogosultjainak száma meghatározza a voksoláson várhatóan megjelenők számát, ezáltal a reactive malapportionment kereteit. Itt kapcsolódik be a megvalósult földrajzi torzulás kialakításába maga a választó. Hiszen a választási részvétellel és a mandátumkiosztásba nem kerülő jelölt és listavoksokkal súlyozza és véglegesíti a választókerületek közötti valós eltéréseket, miszerint kerületekre lebontva hány mandátumkiosztásban szerepet játszó voksból született meg a mandátum. Ezt kiegészítve a gerrymandering tulajdonképp ebből a vokshalmazból az elhanyagolható aktuális parlamenti mandátumkiosztásba kerülő politikai pártok, csoportok szavazatainak térbeli eloszlásával határozza meg a megvalósult földrajzi torzulást.

Fontos kiemelni, hogy a gerrymandering és reactive malapportionment között kölcsönös és folyamatos függési viszony tapasztalható. Ha a modellben bármelyik tényezőben változás történik a választásokon az azonnal hat a többire is, így a földrajzi torzulásokon belül mindkét folyamat hatóerejére is. Például ilyen a mandátumkiosztásba kerülő pártokra, jelöltekre leadott voksok szerepe. Hat a területi aránytalanságra, de a gerrymanderingre is, ha megváltozik a szavazók véleménye, hiszen akkor az formálja a politikai csoportok támogatottságának térbeli eloszlását. Ebből adódóan tulajdonképp egy adott választás során megvalósult földrajzi torzulás főként a reactive malapportionment (választáson megjelentek száma és mandátumkiosztásba nem kerülő voksok) és a gerrymandering (mandátumkiosztásba kerülő politikai csoportok voksai) közötti viszonyrendszeren alapul. 
Ha egy választási rendszert tartósan igazságosnak szeretnénk kialakítani, akkor érdemes hosszabb időtávon is vizsgálni a kereteket, hiszen a földrajzi torzulások dinamikus relációira a markánsabb demográfiai és társadalmi viszonyok is jelentősen hatnak. Ezért szükséges rendszerezni a földrajzi torzulásokra ható tényezőket. A koncepcióban ezeket is sikerült meghatározni és a résztényezőkhöz kapcsolni és azok mentén differenciálni a felsorolt mechanizmusokat.

A döntéshozók oldaláról a földrajzi torzulások folyamatára a hatalmi elit és a politikai csoportosulások több módon hatnak. Elsősorban a választási rendszer átalakításával a kerületek átrajzolásával, a voksolási eljárás (elektronikus, személyes, külföldön élő szavazók lehetőségei, szavazókörök elérése stb.) meghatározásával. Másrészt a meglévő közigazgatási és államhatárok is hatnak a földrajzi torzulásokra. Fontos megemlíteni, hogy a közigazgatási és államhatárok mellett a statikus természeti tényezők (pl. domborzat) is hatnak a választókerületek kialakítására, így a torzulásokra is. Mindemellett a politikai elit rövidebb távon a döntéshozatal mellett a politikai csoportok kampányolási stratégiája és erre költött erőforrások, a kampánytémák és politikai diskurzusok (regionális, országos, nemzetközi léptékü témák) is tudják befolyásolni a választót így a törvényi kereteken belül formálni a torzulás tényezőit.

Ebben a fejezetben az elméleti kereteket továbbfejlesztve megfogalmaztam egy dinamikus elméleti modellt, ami a földrajzi torzulás résztényezői közötti összefüggéseket és az ezekre ható külső folyamatokat foglalja össze. Továbbá szétválasztottam az elgondolt és megvalósult földrajzi torzulást, és hangsúlyoztam az altényezők közötti összefüggések mandátumkiosztásra gyakorolt jelentőségét. Ezt követően a közvetett hatótényezőket is igyekeztem keretbe foglalni, amik hosszabb távon hatnak a földrajzi torzulások mértékére. 


\section{A kutatás során alkalmazott módszerek}

Amennyire szerteágazó a választási rendszerek igazságosságának és földrajzi torzulásainak elméleti értelmezései, annyira nehéz mérni és kimutatni azokat. Megállapítható, hogy a választási rendszerek vizsgálatával kapcsolatosan a nemzetközi politológiai és földrajzi tanulmányokban a kvantitatív kutatási módszerek dominálnak. Ezt részben a kutatások léptéke befolyásolja, hiszen nehéz országos vagy szupranacionális szinten releváns kvalitatív kutatási eredményeket produkálni (LEIB, J.- QUINTON, N. 2011). Ugyanakkor az is leszögezhető, hogy a lokális vagy regionális léptékü választási földrajzi esettanulmányokban a statisztikai elemzések mellett gyakran előkerülnek kvalitatív vizsgálati módszerek is, amivel igyekeztek a választói magatartás mögött meghúzódó mélyebb politikai gazdaságtani hatótényezőket kimutatni (NICLEY, E. P. 2011). Jelen fejezetben a disszertációhoz kapcsolódóan a választási földrajzban a földrajzi torzulások kimutatására szolgáló módszertani lehetőségeket és korlátokat mutatom be.

A doktori értekezésem középpontjában a magyar országgyülési választási rendszer földrajzi jellemzőinek összehasonlító vizsgálata áll. A kutatás elméleti megalapozottságát és a rendelkezésre álló adatok sajátosságait figyelembe véve az elemzések összetett kvantitatív módszereken alapulnak. A továbbiakban elsősorban az adatok gyűjtésének és feldolgozásának módját, annak szintetizálását és az országgyülési választókerületek alaptérképeinek digitalizálási eljárását ismertetem. Ezt követően tematikusan a politikatudományhoz és a választási földrajzhoz kapcsolódó leíró statisztikától kezdve a témakörben releváns regionális elemzési módszereket sorakoztatom fel.

\subsection{A kutatás során felhasznált adatok}

A választási földrajzi kutatásokban a folyamatokat célszerü különböző szinten (szavazókör, település, választókerület) megvizsgálni. A területi szintek változtatása mellett a torzulások kimutatásában a bemeneti adatok fajlagos és abszolút értékeit is össze kell vetni. Fontos kiemelni az adatok gyüjtésével kapcsolatosan, hogy probléma merülhet fel a megfelelö indikátorok térbeli elérhetőségével kapcsolatban. Szavazóköri szinten nem érhetünk el olyan társadalomstatisztikai adatokat, ami szükséges lenne a kerületbeosztások elemzése során, továbbá a szavazókörök is folyamatosan változnak, így az összehasonlítások nem tudnak átfogó képet adni. Erre a kihívásra megoldás lehet a társadalmi és politikai términtázatok kisléptékü összegzésének informatikai módszerei (KovALCSIK T. 2019), a lakossági adatbázisok összefüzése, vagy a közösségi médiából nyerhető adatok hálózatelemzése (BARABÁSI ALBERT L. 2016, 2018, KOVALCSIK T. 2019). A nemzetközi összehasonlítás szintén nehézkes, hiszen az országok között jelentős eltérés tapasztalható a mért statisztikai adatokban, területi lehatárolásokban. Ebbőlkövetkezik, hogy esetünkben az adatok gyüjtésének részleteit is be kell mutatni.

Magyarországon az országgyülési választásokon két szavazatot adhatnak le a polgárok, ahol az egyik voks a helyi képviselőjelöltre, a másik pártlistára vonatkozik. A kutatás a térfelosztás változásának elemzését tűzte ki célul, így a választási eredmények földrajzi elemzései mellett a megállapítások időrendi összehasonlításon is alapulnak. Mivel a korábbi és új választókerületek eltérők, így a különböző egyéni jelöltekre leadott voksokat nem lehet érdemben összehasonlítani és csak korlátozásokkal lehet időbeli elemzéseket végezni. Továbbá az is nehezítő tényező, hogy a korábbi választási rendszerben két eltérő fordulóban szavazhattunk az egyéni jelöltre, míg 2014 óta már csak egy körben dől el az összes mandátum. 
Tehát az egyéni jelöltekre leadott szavazatok alapján lehetetlennek tünik a korábbi és a jelenlegi választási rendszer földrajzi torzulásainak összehasonlítása.

Ugyanakkor a listás szavazatok országos szinten ugyanazt a pártot jelentik, így ezeket időrendben is lehet vizsgálni és modellezni a voksok térbeli eltéréseit. Ebből adódóan munkám során a földrajzi különbségeket, a malapportionment és a gerrymanderig jelentőségét is, valamint a pártok támogatottságának térbeli klasztereit a pártlistákra leadott voksok összevetésével elemzem. Ez azért is járható út, mert Magyarországon a vizsgált időintervallumban ugyanazon politikai közösség esetében a jelölt és listás voksok között erős pozitív korreláció volt. Ezért a listás szavazatok eloszlásából rendszerint hatékonyan lehet következtetni a pártok szavazóbázisára és a földrajzi torzulások jelenségére is.

Így a kutatás során a 2002-es, a 2006-os, a 2010-es, a 2014-es és a 2018-as országgyülési választások adatait használtam fel. A 2002-es és 2006-os országgyűlési választások adatait a Nemzeti Választási Iroda [1] tömbösített adatstruktúrában bocsájtotta rendelkezésemre. A 2010-es, a 2014-es és 2018-as adatokat már Excel formátumban szereztem be. Az adatok térinformatikai és statisztikai használhatósága miatt a jegyzettömb formátumú adatokat át kellett alakítani Excel formátumba, ami külön informatikai adatstrukturálást is jelentett. Az adatok pontosságát többször ellenőriztem, és abban az esetben, ha eltérést találtam a választási adatokat manuálisan gyüjtöttem le a Nemzeti Választási Iroda [1] és a szavazattérkép [2] honlapjáról. Mivel a hazai viszonylatokat célszerü nemzetközi folyamatokkal összehasonlítani, így a főbb választási adatokat néhány külföldi országról is lekérdeztem $[3,4,5]$.

Ezután az adatbázisokat összekapcsoltam választókerületi és települési szinten egyaránt. A településenként összesített választási eredmények segítettek abban, hogy az osztályozásokat és az új választókerületek pártpreferencia besorolását elvégezzem. Az időrendi elemzésben a népességszám és a választásra jogosultak számának változása segített a választókerületek területi aránytalanságainak becslésében is. A választási földrajzi sajátosságok és a társadalmigazdasági mutatók közötti összefüggések feltárásához további adatokra is szükség volt. A kutatáshoz szükséges társadalomstatisztikai adatokat a megfelelő földrajzi léptékre bontva a Központi Statisztikai Hivatal honlapján [6] értem el, míg a települési szinten az adatokat az Országos Területfejlesztési és Információs Rendszer adatbázisából [7] kérdeztem le.

Az adatok beszerzése és szintetizálása mellett a földrajzi és geoinformatikai elemzések elvégzéséhez szükséges volt a korábbi és a jelenleg hatályos választókerületi beosztás alaptérképeinek létrehozása. A 2011 előtti választókerületi beosztást Hegedüs Gábor bocsájtotta rendelkezésemre, míg a 2014-től érvényes beosztást saját magam digitalizáltam be a Központi Statisztikai Hivatal alapján [8], és a törvény szövegét értelmezve megrajzoltam Magyarország jelenlegi választókerületi térképét. Az adatok összeaggregálását és adattisztítását Microsoft Excel programmal végeztem el, míg az alaptérképek létrehozásához és módosításához ArcMap 10.3 és Mapinfo Professional 10.0 szoftverprogramot használtam.

\subsection{A kutatás során használt matematikai és statisztikai módszerek}

Az egyenlőtlen politikai reprezentációt okozó választási rendszerek ritkábban, a földrajzi torzulások folyamatosan változnak. Mivel a választási rendszerek statisztikai elemzése a térbeliség bekapcsolásával nyerhet igazán értelmet, ezért értekezésem jobb megértéséhez szükséges a statisztikai módszertan kifejtése. 
Megállapítható, hogy az egyenlőtlen politikai reprezentáció elsőszámú forrása a választási rendszer típusa, valamint a szavazatok aggregációjának matematikai megoldása és léptéke. Arra a kérdésre, hogy a választási rendszer hogyan alakítja a voksokat képviselöi helyekké, a pártok mandátumarányával és az országos szavazatarány összevetésével kaphatunk választ. Ezt az angolszász választási földrajzi irodalomban „Seats/Votes Ratio” elnevezéssel illetik (JoHnston, R. 2002a). Az eljárás előnye az egyszerü matematikai értelmezhetőség, valamint az, hogy különböző típusú választási rendszereket is könnyen össze lehet vetni ezzel a módszerrel. Ebből adódóan ezzel a módszerrel az elmúlt időszakot tekintve Magyarországot összehasonlíthattam több posztszocialista országgal.

Azonban a mandátum- és voksarány összevetése számos mögöttes folyamatot nem vesz figyelembe. Például érzékeny a vegyes választási rendszerben az egyéni és listás mandátumok megoszlására, valamint a tisztán arányos szisztémában a szavazataggregálási léptékre is. Ezen kívül a pártok mandátumarányát számos tényező befolyásolja, például a jelöltek előzetes koalíciós megállapodásai, a jelöltek kölcsönös visszalépései is. Ebből adódóan szükség van tovább elemezni a választási rendszerek általános aránytalanságait. A szakirodalomban a matematikai eljárások közül számos mérési lehetőséget találunk, ilyen például a Grofmanindex, a Lijphart-index, a Rae-index, a Saint-Lague-index (MONROE, B. L. 1994). Dolgozatomban a politikatudományban két legelterjedtebb aránytalanságot mérő mutatót, a Loosemore-Hanby és a Gallagher indexet használtam (GALlaGHER, M. 1991, MONROE, B. L. 1994, LOOSEMORE, J. - HANBY, V. J. 1971).

A Loosemore-Hanby módszer előnye, hogy a pártok közötti viszonylag kis eltéréseket is jól kimutatja, ami a kétpólusú pártrendszerekben kedvező, viszont részben elfedi a nagyobb eltérések hatását. A Gallagher-index a különbségek négyzetre emelésével és az aggregált érték gyökvonásával a kiugró értékeket próbálja kiemelni. Ezzel ellentétben a kis különbségekre kevésbé érzékeny. Így a módszer előnye az, ami a Loosemore-Hanby-index hátránya és fordítva. Így a doktori kutatásomban 2010 és 2018 között a magyarországi választási rendszerekre kiszámítottam a Loosemore-Hanby- és Gallagher- indexeket. A teljes rendszer aránytalanságai mellett külön-külön megvizsgáltam az egyéni és a listás mandátumok kiosztásának eltéréseit is. A politikatudományban a választási rendszerek aránytalanságát mérő indexek nem geográfiai megközelítésüek, ezért csak korlátozottan alkalmasak a térbeli hatások feltárására. Ezért a földrajzi hatótényezők kimutatására konkrétan létrehozott matematikai módszereket és a területi statisztika módszereit is alkalmaztam.

A földrajzi torzulások vizsgálhatók egyszerü leíró statisztikával, valamint a területi egyenlőtlenségeket mérő eljárásokkal (LI, W. et al. 2015). A statisztikai programokba a bemeneti változókat a társadalmi és gazdasági adatok, valamint az országgyülési választások listás voksarányai képezték választókerületi és települési szinten. Első lépésben a 2002 és 2018 közötti időben a választásra jogosultak aránya, a részvétel és a politikai pártok eredményeinek leíró statisztikája (átlag, medián, terjedelem, szórás) az alapvető összefüggések és térbeli sajátosságok feltárásához nyújtott segítséget. Azonban, mivel a földrajzi torzulások természetét a társadalom demográfiai jellemzői, továbbá a politikai véleményformálás is dinamikusan változtatja, ezért célszerü volt további módszereket is alkalmazni.

Módszertani szempontból több tanulmány az adatok Pearson és Spearman korrelációját, lineáris regresszióját elemzi (CoMA, F. M. - LAGO, I. 2016, LAGO, I. - LoBO, M. C. 2014), azonban az összetettebb társadalmi folyamatok bonyolultsága miatt az eltérések meghatározásánál érdemes parciális korrelációt és többváltozós regressziót is alkalmazni (DuseK T. - Kotosz B. 2016, SHIN, M. - AGNEW, J. 2011), hogy értelmezni tudjuk a mélyebb összefüggéseket. Emellett a területi egyenlőtlenségeket mérő regionális elemzési mutatók számos lehetőséget nyújtanak, hiszen a jövedelmi különbségeken túl további társadalmi tartalommal bíró mennyiségi ismérvek eloszlását is lehet velük vizsgálni (DUSEK T. 2004, 
DuseK, T. - Kotosz, B. 2016, SÁNTA É. el al. 2015).

Ebből adódóan a társadalmi egyenlőtlenségeket mérő mutatók közül jól alkalmazható esetünkben a Variációs együttható, a Herfindahl-Hirschman-, a Hoover- és a Gini-index (BOCHSLER, D. 2010, NÉMETH N. 2005). Így a gerrymandering jelenségét a pártok szavazatainak térbeli eloszlásának egyenlőségével vizsgáltam. Ezért a 2002 és 2018 közötti választások eredményeiből az eltérő megoszlást Hoover-indexekkel, valamint súlyozatlan és súlyozott Gini-indexekkel mutattam ki választókerületi és települési szinten. A megoszláson alapuló módszerek mellett súlyozott relatív szórást és nem utolsó sorban a koncentráció mérésére Herfindahl-Hirschman indexeket is kiszámítottam a választókerületi beosztást figyelembe véve, amivel ellenőrizni tudtam a Hoover- és Gini-indexekből kiolvasható trendeket. Az imént felrosolt regionális elemzési mutatók részletes matematikai módszereinek bemutatásától eltekintek, hiszen ezt számos korábbi tudományos mü már megtette (DUSEK T. 2004, DuseK, T. - Kotosz, B. 2016). Esetemben azért fontosak ezek a módszerek, mert más és más szempontból emelik ki a területi egyenlőtlenségeket és így kimutathatóvá váltak a változó térfelosztás hatásai a pártok sikerességére.

A választási földrajzi tagoltság megállapítása mellett a társadalmi törésvonalak feltárásához és a kerületek társadalomföldrajzi jellemzéséhez elsősorban Pearson korrelációt, Spearman rangkorrelációt, valamint parciális korrelációt és lineáris regressziót használtam. A társadalmi státusz meghatározásánál csak a rendelkezésre álló 2011-es népszámlálási adatokra tudtam támaszkodni, s azt az iskolázottsággal és a foglalkoztatottsággal kapcsoltam össze. Az etnikai és vallási törésvonalakat a romák, valamint a katolikusok, reformátusok, evangélikusok és ateisták választókerületi arányaival értelmeztem. További módszertani megjegyzés, hogy az etnikai és vallási felekezethez tartozó csoportok arányát az összes válaszadókhoz viszonyítottam, és nem a népességhez, hiszen a népszámlálásnál az állampolgárok több választ is megjelölhettek, ami az arányok választókerületi eloszlását döntően nem befolyásolta. Fontos megjegyzés, hogy a 2011-es népszámlálási adatok már nem olyan korszerűek így csak korlátozott következtetéseket lehet levonni föleg a 2018-as választási adatokkal összefüggésben annak ellenére, hogy választókerületi léptéken még így is releváns viszonyítási adat a 2011-es adatfelvétel.

Az ok-okozati kapcsolatokat átgondolva főkomponens elemzést is végeztem. A választási részvételt meghatározó regionális versenyképesség fökomponensének mutatóit az egy lakosra jutó jövedelem (2011), a foglalkoztatottsági ráta (2011) és a felsőfokú végzettségüek aránya (2011) adta. A fókomponens létrehozásánál a statisztikai szabályok pontos betartását tartottam szem elött, ennek megfelelően a létrehozott indikátor a következő tulajdonságokkal rendelkezett. Egyrészt a KMO érték 0,645 volt, másrészt a magyarázott varianciahányad nagyobb értéket vett fel, mint 75\%, és harmadrészt a főkomponens sajátértéke 2,26 volt. Ez mind teljesíti a statisztikai feltételeket (Molnár T. 2015, SAJTOS L. - Mitev A. 2007). Az okokozati kapcsolatok időbeliségét figyelembe véve (a magyarázó változó későbbi dátum) fontos kiemelni, hogy a regionális versenyképesség fökomponens 2010-es választási részvétellel való kapcsolata csak megkötésekkel értelmezhető, de a föbb trendek kimutatásában így is jelentős.

Elméleti szempontból az ok-okozati viszonyok elemzésénél célszerü a linearitást is megkérdőjelezni, hiszen többször a választói magatartásra a társadalmi tényezők nem egyenesen arányosan hatnak. Továbbá a megfelelő mutatók kiválasztásának nehézségei mellett többször a választott területi lépték is befolyásolja az eredményeket. SHIN és ANGEW (2011) kutatásai arra mutattak rá, hogy a változók általános korrelációjával és regressziójával szemben a területi autókorreláció és a földrajzilag súlyozott regresszió eredményei is térben eltérő eredményeket hozhatnak. Ennek okai a társadalmi-gazdasági jelenséget magyarázó (FOREST, B. 2013), - az eddig említett elméleti modelleken túlmutató - összetett tényezőkben és a térbeli különbségek mögött meghúzódó egyéni döntésekben keresendő. Ezért a kutatásomban 
geoinformatikai módszereket is használtam (ANSELIN, L. 1995, SZAKÁLNÉ KANÓ I. 2011).

A tudományos közélet a földrajzi torzulások összetettebb kimutatására a területi statisztikából ismert módszereket is átveszi (BOCHSLER, D. 2010, DuSEK T. - KOTOSZ B. 2016). A választási eredmények kiértékelésénél és területi statisztikai értelmezésénél az egyik legelterjedtebb térbeli elemzési eljárások közé sorolható a K-közép klaszter, az Anselin féle Local Moran's és a Getis-Ord féle lokális G*i statisztika (LI, W. et al. 2014, TóTH G. 2003). Ebből adódóan az ország választókerületi szintü politikai tagoltságának mérésére hierarchikus és K-közép klaszteranalízist alkalmaztam, ahol a parlamentbe bejutó pártok listás eredményei képezték a bemeneti adathalmazt. A szakirodalmi javaslatokat követve (FALUS I. - OLLÉ J. 2008, SAJTos L. - MiteV A. 2007) első lépésben hierarchikus, Ward eljárás elvén alapuló módszert használtam a kialakítandó klaszterek ideális számának meghatározásához. Ezt követően a dendrogram alapján 2002-re és 2006-ra négy, valamint 2010-től minden esetben öt csoportot határoltam le úgy, hogy a harmadik iteráció volt a határ. Mivel a hierarchikus elemzés nem mutatja a klaszterek egyediségének részleteit azért második lépésben a csoportok részletes tulajdonságait a K-közép eljárással tártam fel (SAJTOS L. - MiteV A. 2007, SzÉKELY M. BARNA I. 2008).

Kutatásom során a lokális összefügések feltárásában célszerü volt további területi statisztikai módszereket is használni. Így a választókerületek által elfedett települési szintű szomszédságok elemzéséhez területi autokorrelációt használtam, azon belül is a Local Moranindexet, valamint a Getis-Ord féle G*-indexet (ANSELIN, L. 1995, GETIS, A. - ORD, J. K. 1992, GETIS, A. 1995). Az ArcGIS geoinformatikai szoftverben számos eltérő lehetőség van mérni a területi autokorrelációt ezért a regionális elemző módszerekkel ellentétben itt szükségesnek tartottam a matematikai eljárás pontosabb bemutatását. A Getis-Ord féle lokális $\mathrm{G}^{*}$ i statisztika minden területi egységre egy adott értéket ad, az alábbi képlet szerint:

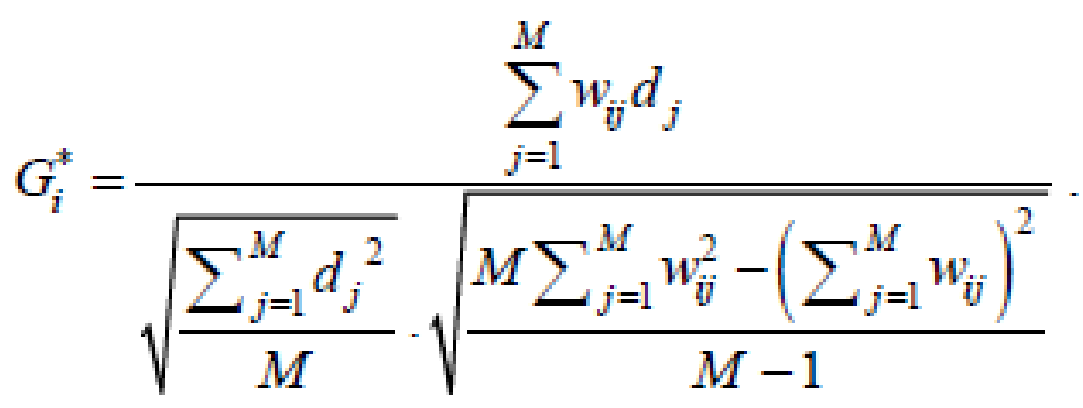

Ennek a mutatónak a számlálójában a vizsgált indikátor értéke, valamint a dj értékeknek a szomszédsági mátrix i-edik sorában szereplő elemeivel súlyozott összege látható, a nevezőben lévő értékek pedig a standardizálást szolgálják (GETIS, A. - ORD, J. K. 1992, SZAKÁLNÉ KANÓ I. 2011, 2017). Ez a statisztikai eljárás megfelelö geoinformatikai szoftverrel egyszerre kiszámítható és térképre vihető. Az értékek következőképp értelmezhetők. Ha Gi* > 1,96 akkor ún. hot spot, hiszen a területi egységben és környékén magasabb az értékek koncentrációja. Ha -1,96< < Gi* <1,96 akkor a 0-tól való eltérés nem minősül szignifikánsnak. Míg, ha a Gi* <-1,96 akkor ún. cold spot, hiszen a területi egységben és környékén jellemzőbb az alacsonyabb értékek koncentrációja (SZAKÁLNÉ KANÓ I. 2011). 
A Getis-Ord mutató mellett a Local Moran-index (Tóth G. 2003, SzAKÁLnÉ Kanó I. 2011, 2017) is felhasználásra került a választási földrajzi mintázatok kimutatásában az alábbi képletet használva a szoftverben:

$$
I_{i}=M \frac{d_{i} \sum_{j=1}^{M} w_{i j} d_{j}}{\sum_{j=1}^{M} d_{j}{ }^{2}}
$$

A mutató számlálójában a vizsgált indikátor értéke található, valamint a dj értékeknek a szomszédsági mátrix i-edik sorában szereplö elemeivel súlyozott összegei, a nevezőben lévő értékek pedig a Getis-Ord féle mutatóhoz hasonlóan a standardizálást szolgálják. Annyiban tér el a Local Moran-index a másik módszertől, hogy a magas-alacsony és alacsony-magas szomszédsági kapcsolatokat is kiszámítja. Végezetül a területi autokorreláció mellett a kutatásomat az általános ok-okozati modelleket a szakirodalmi javaslatokat követve a földrajzilag súlyozott regresszió módszerével egészítettem ki (FÁBIÁN Zs. 2013, SHIN, M. AGNEW, J. 2011), amivel a választási részvétel és pártok beágyazottságának időbeli kapcsolódásait mutathattam ki.

Összegezve a kutatás során használt módszertani eljárásokat megállapítható, hogy a választókerületi szintü és országos összefüggéseket regionális elemzési módszerekkel mutattam ki. Az általános ok-okozati kapcsolatok feltárása mellett a választókerületi léptéknél részletesebb települési sajátosságok kimutatására már a területi statisztikai és informatikai eljárásokat alkalmaztam. A vizsgálatokat Microsoft Excel és IBM SPSS 22, 23, 24 programokkal végeztem el, valamint az alaptérképek létrehozásához és módosításához ArcMap 10.3 és Mapinfo Professional 10.0 szoftverprogramot használtam. 


\section{A magyar választási rendszer aránytalanságai és a politikai pártok támogatottságának földrajzi jellemzői}

A disszertáció több területi szinten próbálja leírni a magyar választási rendszer összetett földrajzi sajátosságait. Ebből adódóan jelen fejezet az alábbi szerkezetet követi. Elsőként összevetem a posztszocialista országok mandátum- és szavazatarány értékeit, majd ebben helyezem el Magyarországot. Ezután a 2002 és 2018 között lezajlott országgyülési választások tükrében a magyar választási rendszer általános aránytalanságait mutatom be különbözö mutatók alapján. Végezetül az elmúlt öt országgyülési választás alapján a parlamentbe bejutott pártok térbeli beágyazottságát elemzem a változó választói magatartás és kerülethatárok tekintetében.

\subsection{A magyar választási rendszer általános aránytalanságai nemzetközi összehasonlításban}

A választási rendszerek általános aránytalanságát úgy jellemezhetjük legkönnyebben, ha összevetjük a győztes pártok mandátumarányait az országos parlamenti választáson elért szavazataránnyal. A 4. ábra és az 5. táblázat az elmúlt 20-25 évet öleli fel és mutatja be Magyarország és több posztszocialista ország esetében az országgyülési választásokon győztes pártok mandátum- és szavazatarányát. A mutató időbeli változásából kiolvasható, hogy az elméleti fejezetben részletezett posztszocialista választási rendszerek hogyan alakították a szavazatokat mandátumokká.

4. ábra: A posztszocialista országok győztes pártjainak mandátum és szavazatarányának dinamikus változása a legutóbbi hét országgyülési választás (1995-2018) eredményei alapján

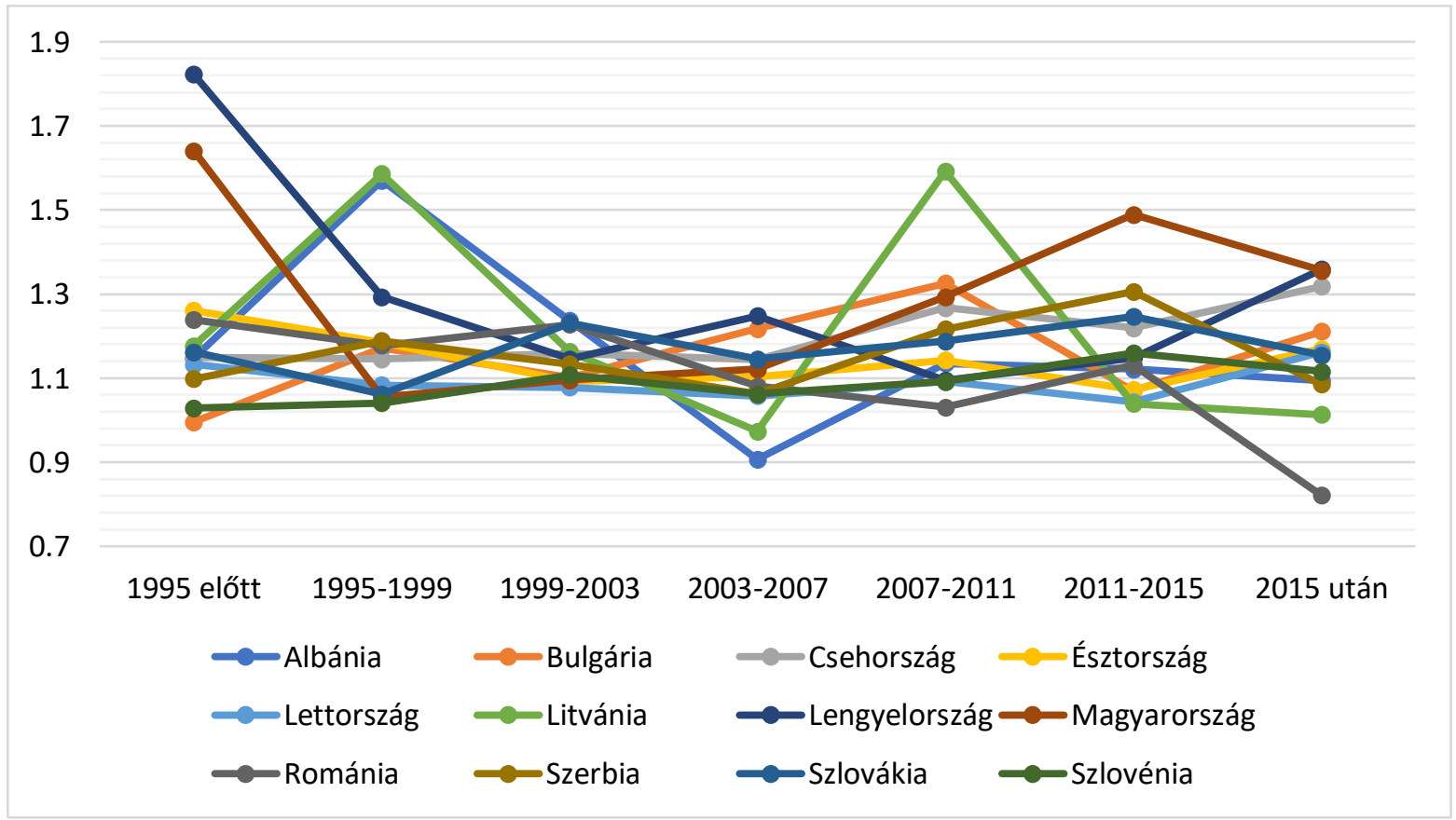

Forrás://www.parties-and-elections.eu/countries.html honlap adatai alapján saját számítás és szerkesztés 
Mint arra korábban utaltam egyik szisztéma sem adja vissza teljesen igazságosan a választók akaratát, de a rendszerváltozást követően kimutatható, hogy a listás választási rendszerekben kisebb az általános aránytalanság, mint a vegyesekben. Szeretném kiemelni, hogy nemcsak a választási rendszer torzítja az eredményeket, hanem a pártstruktúra helyi beágyazottsága is fontos. Például ugyanaz a rendszer más aránytalanságot mutathat két domináns párt megléte vagy plurális keretek között. A vizsgált országokban így is általában 1,05 és 1,3 között torzít a győztes pártok felé a rendszer, viszont néhány állam esetében az említett tényezők miatt kiugró értékek is megfigyelhetők.

5. táblázat: A posztszocialista országok győztes pártjainak mandátum- és szavazatarány értékei a legutóbbi hét országgyúlési választás (1995-2018) eredményei alapján

\begin{tabular}{|c|c|c|c|c|c|c|c|}
\hline & $\begin{array}{l}1995 \\
\text { elött }\end{array}$ & $\begin{array}{c}1995- \\
1999\end{array}$ & $\begin{array}{c}1999- \\
2003\end{array}$ & $\begin{array}{c}2003- \\
2007\end{array}$ & $\begin{array}{c}2007- \\
2011\end{array}$ & $\begin{array}{c}2011- \\
2015\end{array}$ & $\begin{array}{c}2015- \\
2018\end{array}$ \\
\hline Albánia & 1,15 & 1,57 & 1,24 & 0,91 & 1,14 & 1,12 & 1,09 \\
\hline Bulgária & 1,00 & 1,17 & 1,10 & 1,22 & 1,33 & 1,07 & 1,21 \\
\hline Csehország & 1,15 & 1,15 & 1,16 & 1,14 & 1,27 & 1,22 & 1,32 \\
\hline Észtország & 1,26 & 1,18 & 1,09 & 1,10 & 1,14 & 1,07 & 1,17 \\
\hline Lettország & 1,13 & 1,08 & 1,08 & 1,06 & 1,09 & 1,04 & 1,16 \\
\hline Litvánia & 1,18 & 1,59 & 1,16 & 0,97 & 1,59 & 1,04 & 1,01 \\
\hline Lengyelország & 1,82 & 1,29 & 1,15 & 1,25 & 1,09 & 1,15 & 1,36 \\
\hline Magyarország & 1,64 & 1,06 & 1,10 & 1,12 & 1,29 & 1,49 & 1,36 \\
\hline Románia & 1,24 & 1,18 & 1,23 & 1,08 & 1,03 & 1,13 & 0,82 \\
\hline Szerbia & 1,10 & 1,19 & 1,13 & 1,06 & 1,22 & 1,31 & 1,08 \\
\hline Szlovákia & 1,16 & 1,06 & 1,23 & 1,15 & 1,19 & 1,25 & 1,15 \\
\hline Szlovénia & 1,03 & 1,04 & 1,11 & 1,06 & 1,09 & 1,16 & 1,12 \\
\hline
\end{tabular}

Forrás://www.parties-and-elections.eu/countries.html honlap adatai alapján saját számítás és szerkesztés 
Érdekesség, hogy a vizsgált országok közül Litvániában az utóbbi két választáson a rendszer nem a győztes pártnak kedvezett, hiszen a második helyezett sokkal több mandátumot nyert el az egyéni választókerületekben, a politikai megállapodások eredményeként. Így a litván választásokon győztes párt mandátumaránya jól korrelált a végeredménnyel, ezért csökkent drasztikusan a mutató értéke, viszont a valóságban hosszabb időtávot figyelembe véve ez a vegyes rendszer még a magyar viszonyokhoz képest is aránytalanabb módon és hektikusabban képezi le a választók akaratát.

A többi országgal összevetve Magyarország a kezdeti kiugróan aránytalan értéke $(1,64)$ után belesimult a térségi átlagba, majd az új választási törvényt követő választáson a térség akkori legigazságtalanabb értékét $(1,49)$ mutatta. Ennek oka eleinte a magyar pártstruktúra átalakulása 2010-ben, amit 2014-re a választási rendszer jelentős átalakítása is felerősített. A 2018-as választások eredményei viszont visszatükrözik azt az elméleti koncepciót, hogy idővel a politikai szereplők és a választók is alkalmazkodnak az új helyzethez és reagálnak a megváltozott játékszabályokra (ENYEDI Zs. - KÖRÖSÉNYI A. 2004). Ezért 2014-hez képest csökkent az aránytalanság, de összehasonlítva más országokkal az új rendszer még mindig az egyik legaránytalanabb a térségben.

Ha a nemzetközi összevetéstől eltekintünk és teljesebb képet szeretnénk kapni Magyarország helyzetéröl, akkor a választási rendszer aránytalanságát nemcsak a győztes pártok mandátumarányaival érdemes megvizsgálni. Ezért Magyarország 2002-es, 2006-os, 2010-es, 2014-es és 2018-as országgyülési választásainak példáján összegezve a LoosemoreHanby és Gallagher indexekkel érzékeltetem a választási rendszer általános aránytalanságának összetett tulajdonságait (6. táblázat).

Megállapítható, hogy 2002-ben a megosztó politikai csatározás ellenére a választási rendszernek nagyobb aránytalansága volt. Ennek egyik oka a két választási forduló közötti mozgósítása a Fidesz-MDF szövetségnek, hiszen az országos eredményéhez képest sok billegő választókerületet tudott elhozni a második körben. A nagy aránytalanság másik oka, hogy a MIÉP éppen lemaradva a parlamenti küszöb alatt szerepelt $(4,6 \%)$, így nem került be a törvényhozásba. Hasonlóan szerepelt a Centrum $(3,97 \%)$ is és a Munkáspárt $(2,16 \%)$ is értékelhető eredményt ért el. Így a listás voksoknak összesen több mint 10 százaléka nem eredményezett egy mandátumot sem. Ezt jól tükrözi, ha az egyéni és listás mandátumokat külön értelmezzük az indexekkel. Mindkét mutatóval összevetve csak a 2002-es adatoknál tapasztalható, hogy a listás mandátumkiosztás nagyobb aránytalanságot mutat, mint az egyéni.

Ha a 2002-es értékeket összevetjük a négy évvel későbbi országgyülési választás eredményeivel, akkor megállapítható, hogy 2006-ban volt a legkisebb a magyar választási rendszer általános aránytalansága. Ennek oka alapvetően két tényezőre vezethető vissza. Egyrészt a pártrendszer dualitása megmaradt és emellett a választók nem adtak le sok szavazatot a parlamenti tömörüléseken kívüli formációkra. A MIÉP-Jobbik $(2,20 \%)$ mellett az összes többi párt kevesebb mint 1 százalékot ért el. Így az egyéni változatlansága mellett a listás voksokhoz mért kiosztható mandátumok aránytalansága lecsökkent. Másrészt az első forduló eredményeit követően az MSZP és SZDSZ a második körben meg tudta tartani előnyét és a Fidesz-KDNP nem tudott fordítani a kerületek jelentős részében, mint négy évvel korábban. Ebböl adódott össze az akkori relatíve alacsony aránytalanság.

Megállapítható, hogy a 2006-os legkisebb értéket követően 2010-re jelentős növekedés volt tapasztalható a választási rendszer mandátumkiosztási aránytalanságában. A pártrendszer átalakulásával, egy nagypárt dominanciájával és a sok közepes és kispárt széttartása miatt az egyéni mandátumoknál kimagasló aránytalanság alakult ki. 2010-ben nem történt jelentős trendváltás a két választási forduló között, így a szisztémában a kompenzáció mértéke is nagyobb volt az ellenzékbe került pártoknak, mivel összesen 3 egyéni kerületben nem nyert a Fidesz-KDNP. 
6. táblázat: A magyar választási rendszer általános aránytalanságai a vizsgált mutatók alapján 2002 és 2018 között

\begin{tabular}{|c|c|c|c|}
\hline & $\begin{array}{c}\text { Teljes rendszerre } \\
\text { vetítve }\end{array}$ & $\begin{array}{c}\text { Egyéni mandátumokra } \\
\text { vetítve }\end{array}$ & $\begin{array}{c}\text { Listás mandátumokra } \\
\text { vetítve }\end{array}$ \\
\hline $\begin{array}{l}\text { Loosemore-Hanby's } \\
\text { Index } 2002\end{array}$ & 11,95 & 15,74 & 22,62 \\
\hline $\begin{array}{l}\text { Loosemore-Hanby's } \\
\text { Index } 2006\end{array}$ & 6,99 & 15,88 & 9,05 \\
\hline $\begin{array}{l}\text { Loosemore-Hanby's } \\
\text { Index } 2010\end{array}$ & 15,40 & 45,57 & 27,39 \\
\hline $\begin{array}{l}\text { Loosemore-Hanby’s } \\
\text { Index } 2014\end{array}$ & 21,96 & 46,53 & 18,17 \\
\hline $\begin{array}{l}\text { Loosemore-Hanby's } \\
\text { Index } 2018\end{array}$ & 17,56 & 37.96 & 21,78 \\
\hline Gallagher Index 2002 & 10,13 & 12,69 & 18,74 \\
\hline Gallagher Index 2006 & 5,47 & 12,63 & 7,22 \\
\hline Gallagher Index 2010 & 12,19 & 37,08 & 20,31 \\
\hline Gallagher Index 2014 & 17,65 & 38,22 & 12,87 \\
\hline Gallagher Index 2018 & 13,99 & 31,63 & 16,37 \\
\hline
\end{tabular}

Forrás: Nemzeti Választási Iroda adatai alapján saját szerkesztés

Az indexekből kirajzolódik, hogy 2010-ről (az átalakítást követően) 2014-re a magyar választási rendszer aránytalanabb módon képezte le a választók akaratát, akkor is, ha az összes pártot górcső alá vesszük. Megállapítható, hogy az indexek a többségi rendszerelemek súlyának emelkedését tükrözik, hiszen korábban a mandátumok 45,6\%-át lehetett egyéni választókerületekben megszerezni, ami 53,3\%-ra módosult. További változás, hogy az eddigi kétfordulós választásokat felváltotta az egyfordulós, így a kerületekben elég volt relatív győzelmet aratni, ami hatott az aránytalanságra. 
Amennyiben a vegyes választási rendszer két pillérét szétválasztjuk, kimutatható, hogy a két rész külön-külön hogyan osztja ki a mandátumokat. Megállapítható, hogy 2014-re az új szisztéma a korábbi keretfeltételhez képest az egyéni mandátumokat aránytalanabb módon, míg a listás helyeket viszonylag arányosabban osztotta ki. Ennek egyik technikai oka a győzteskompenzáció, ahol a győztes jelöltre leadott plusz voksok is a rendszerbe kerültek. Ez a korábbi ellenzéket kárpótló mechanizmust gyengítette és a mindenkori győztes pártok helyzetét erősítette. A másik ok a listás szavazatok arányosabb kiosztása mögött földrajzi eredetü, hiszen 2014-től megszünt a megyei lista, továbbá a szavazatokhoz hozzáadódtak a határon túli voksok mellett a töredékszavazatok is. Ezért a korábbiakhoz képest közel kétszeres vokshalmaz alakult ki, és mivel az egész ország képezte a számítás földrajzi keretét arányosabb listás mandátumkiosztást tapasztalhattunk.

A 2018-as választási eredmények tükrében már összehasonlítható az új rendszer, ahol érezhetően az aránytalanságra is hatott a taktikai szavazás és az ellenzék irányított mozgósítása. Az általános aránytalanság csökkent, hiszen a kormányzó pártok jelentősen növelték a szavazóbázisukat, ennek ellenére mandátumarányuk nem változott 2014-hez képest. Az egyéni választókerületek mandátumainak kiosztásánál érdemben csökkent az érték, viszont a listás szavazatoknál nagyobb aránytalanság lett, aminek oka a parlamentbe be nem jutott pártokra leadott voksok közel megduplázódása 2018-ra (VIDA GY. - KOVALCSIK T. 2018).

Összességében megállapítható, hogy 2002-ben a relatíve nagyobb aránytalanságot a parlamenti küszöböt át nem lépö pártokra leadott felesleges szavazatok okozták, mivel ez akkor jelentős volt. 2006-ban a parlamenti pártokra fajlagosan sokkal nagyobb arányban szavaztak, mint négy évvel korábban, így ez a vizsgált időszak legegyenletesebb mandátumkiosztását okozta. 2010-ben földcsuszamlásszerü győzelmet aratott a Fidesz-KDNP és a pártrendszer átalakult, ez magas aránytalansági indexeket eredményezett. A Loosemore-Hanby és a Gallagher Index segítségével részben már kimutatható a földrajzi lehatárolás hatása is a magyarországi voksokban, hiszen a megyei lépték kiesésével részben arányosabb lett a listás szavazatok kiosztása, viszont a rendszer kompenzációs oldala csökkent. Így a választási rendszer hatásaként lehet értelmezni azt, hogy 2010-hez képest 2014-re az aránytalanság nagyobb volt. Azonban szükséges hangsúlyozni a választópolgárok akaratának és a pártstruktúra változásának tényezőit is, hiszen az új keretfeltételekhez igazodva 2014-hez képest 2018-ra már érdemben csökkent az aránytalanság, részben a taktikai szavazás felerősödése, részben a pártok koordinált indulása miatt.

\subsection{A politikai pártok szavazóbázisának változása 2002 és 2018 között az átalakuló választókerületi beosztás tükrében}

A magyarországi választási földrajzi térszerkezetben egyszerre jelentkezik egyfajta állandóság és változás. A politikai pártoknak jól lehatárolt földrajzi tömegbázisa van, azonban választásról választásra bizonyos változások is megfigyelhetők. Megállapítható, hogy a kétezres évek elejére stabilizálódott a kétpólusú választói magatartás, ami 2010-ben alakult át ismét jelentősen, amire később a választókerületek átrajzolása is hatott. A gerrymandering mértéke elsősorban a pártok szavazóbázisának földrajzi eloszlásától függ, így első lépésben az SPSS program segítségével kerületi szinten hierarchikus, majd k-közép klaszterelemzéssel vizsgáltam a 2002 óta eltelt országgyülési választások földrajzi térszerkezetét. 
A klaszterelemzés feltételeinek vizsgálatához a statisztikai szakirodalom szerint több feltételeknek kell megfelelni. Egyrészt azonos skálákat kell használni, másrészt a mintának reprezentatívnak kell lennie és harmadrészt ajánlatos követnie a mintának a normális eloszlást (FAlus I. - Ollé J. 2008, SAJTos L. - MiteV A. 2007). Továbbá fontos megjegyezni, hogy a klaszteranalízis érzékeny a bemeneti változók erős korrelációjára, valamint a kiugró értékekre (MOLNÁR T. 2015), amit figyelembe vettem számításaimban.

Választási földrajzi elemzésem korlátairól megállapítható, hogy azonos skálákat alkalmaztam és reprezentatív volt az összes minta. A normális eloszlás a vizsgált időszak alatt a közepes és nagypártok esetében minden választáson érvényesült. A kispártok közül az MDF esetében is normális eloszlást követett a minta, azonban az SZDSZ az LMP és a DK esetében ez kismértékben sérült. Ennek az oka e pártok erös urbánus jellegéből adódik. Mindemellett esetünkben a pártok listás eredményei közötti közepes korrelációkat tapasztaltam, ami a választási földrajzban természetes jelenség, főleg, ha jellemző a pártrendszer dualitása, vagy kispártok is vannak (PATTIE, C. - JOHNSTON, R. 2009).

Ha a számításaim során érvényesítettem volna a szigorú statisztikai megkötéseket, akkor az a párlisták eredményeinek elhagyása vagy fökomponensbe tömörítése során kialakult információvesztés miatt a térbeli sajátosságok csorbulását hozta volna. Ezért maradtam az eredmények közvetlen használatánál, hiszen erre nemzetközi példákat is találtam. Angolszász országokban sok helyen csak két vagy három politikai tömörülés van mégis többek mellett kközép eljárásokkal mutatták be a térbeli mintázatot (JOHNSTON, R. et al. 2019, KIM, J. et al. 2003), továbbá a társadalmi törésvonalak elméletének statisztikai kimutatásánál is tapasztalható földrajzi klaszterek meghatározása (JEFFERSON, W. 2005). Ebböl adódóan a nemzetközi választási földrajzi szakirodalmat követve határoztam meg Magyarország választási földrajzi klasztereit 2002 és 2018 között.

\subsubsection{A 2002-es országgyűlési választások földrajzi jellemzői}

Az 1989-ben létrehozott választási rendszer a 2002-es országgyülési választásokon negyedik alkalommal került alkalmazásra. Az eredmények alapján megállapítható, hogy a kilencvenes években a választói magatartásban bekövetkező dinamikus változásokat követően 2002-re megszilárdult a kétpólusú pártstruktúra (FOWLER, B 2003, 2007, KITCHELT, H. 1995, RÁCZ, B. 2003). Az egyik oldalon a baloldal és a liberálisok alkottak egy tömböt, míg a másikon a keresztény, kisgazda és konzervatív értékekre építő jobboldali pártok sorakoztak fel. A rendszerváltozás óta a legmagasabb részvétellel zajlott le a választás, 70,53\%-os aktivitás mellett az MSZP 42,05\%-ot szerezve megnyerte a választásokat. A Fidesz-MDF kormánykoalíció 41,07\%-os eredménnyel jelentősen megerősödött 1998-hoz képest, de összességében elveszítette a választásokat. A harmadik szocialistákhoz kapcsolható pólus, a liberális SZDSZ 5,57\%-os eredménnyel éppen bejutott, míg a MIÉP a bejutási küszöb alatt kiesett a parlamentből. A 176 egyéni mandátumból az MSZP önállóan 78-at, a liberálisokkal közösen egyet, míg a SZDSZ önállóan kettőt szerzett meg.

A jobboldalon a második forduló előtti nagy mozgósítással a Fidesz-MDF szövetség 95 mandátumot nyert el. A listás eredmények alapján számolt hierarchikus és k-közép klaszterelemzés azt mutatta ki, hogy a gyenge többséget szerző MSZP-SZDSZ győzelem mellett milyen választási földrajzi térszerkezet alakult ki (5. ábra, 7. táblázat). 


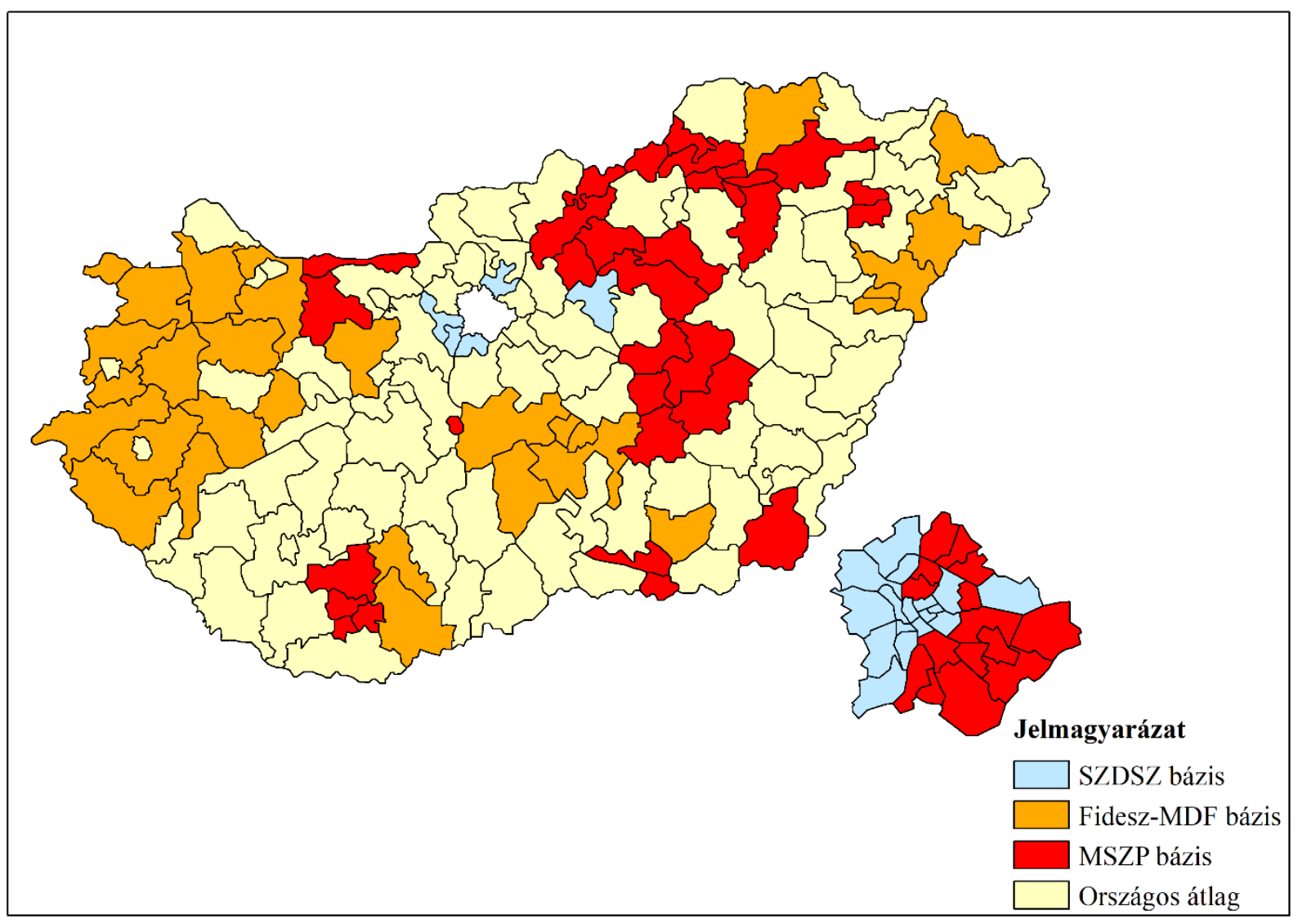

Forrás: Nemzeti Választási Iroda adatai alapján saját számítás és szerkesztés

7. táblázat: Magyarország 2002-es választási földrajzi klaszterei a középpontokkal

\begin{tabular}{ccccc}
\hline Klaszterek és középpontjai & $\begin{array}{c}\text { SZDSZ } \\
\text { bázis (22) }\end{array}$ & $\begin{array}{c}\text { Fidesz-MDF } \\
\text { bázis (29) }\end{array}$ & $\begin{array}{c}\text { MSZP } \\
\text { bázis } \\
(47)\end{array}$ & $\begin{array}{c}\text { Országos } \\
\text { átlag (78) }\end{array}$ \\
\hline MSZP & 39,76 & 33,43 & 49,94 & 41,16 \\
Fidesz-MDF & 34,77 & 53,50 & 32,41 & 43,97 \\
SZDSZ & 10,69 & 3,72 & 5,58 & 4,45 \\
\hline
\end{tabular}

Forrás: Nemzeti Választási Iroda adatai alapján saját számítás és szerkesztés

A vizsgálat során négy markáns térbeli jellegzetességgel rendelkező klasztert sikerült kimutatni. Az első, „SZDSZ bázis” klaszterbe 22 olyan választókerület került, ami főként Budapest budai és belvárosi területeit foglalták magukba. A fővároson kívül is főként az agglomerációhoz kapcsolható, gazdaságilag fejlettebb területek kerültek ebbe a csoportba. Ezekben a választókerületekben az SZDSZ az országos eredményének legalább kétszeresét tudta felmutatni, míg az MSZP kis mértékben átlag alatt szerepelt. A jobboldalt megtestesítő Fidesz- MDF koalíció ezeken a területeken mélyen átlag alatt szerepelt. A liberális bázis mellett különleges mintázat, hogy a MIÉP is föleg Budapesten és a nagyvárosokban szerepelt jól, holott a hasonló értékrendet képviselő pártok inkább vidékies jegyekkel írhatók le (VIDA GY. KovÁCs Z. 2017). 
A második, „Fidesz-MDF bázis” csoportba 29 választókerület került. Vegyes, de többnyire vidéki területek alkották ezt a csoportot, ahol a Fidesz-MDF az országos értékhez képest több mint 10 százalékponttal jobban szerepelt, míg a szocialisták és a liberálisok itt teljesítettek a legrosszabbul. Az SZDSZ ezeken a területeken a bejutási küszöb alá került. Földrajzi szempontból Kecskemét és Debrecen mellett vidékies területek tartoznak ide, mint a kisgazda hagyományokban gazdag Bács-Kiskun megye északi része, a gazdaságilag fejlettebb Győr-Moson-Sopron, Vas, Veszprém és Zala megye kerületei és Hajdú-Bihar, illetve SzabolcsSzatmár-Bereg megye fejletlen határ menti részei.

A harmadik, „MSZP bázis” klaszterébe 47 választókerület került. Ez a csoport is vegyes képet alkot, hiszen alapvetően városias kerületek tartoznak ide, például a főváros pesti oldala, vagy Dunaújváros, Miskolc, Pécs, Szeged mellett szép számmal sorakoznak a rendszerváltozást követő ipari hanyatlást megélt gazdasági válságterületek is, jelentős roma lakossággal (PÉNZES J. et al. 2018). 2002-ben alapvetően kirajzolódott a hajdani szocialista iparban dolgozó munkásosztály által lakott területek baloldali preferenciája. Megállapítható, hogy a szocialisták itt korábban is jól szerepeltek, így majdnem 50\%-os támogatottságot érték el, az SZDSZ átlagos, valamint a Fidesz-MDF mind közül legrosszabb teljesítményével szemben.

A negyedik, „Országos átlag” csoportba 78 választókerület került. A klaszter szinte tökéletesen leképezte az országos végeredményt, annyi különbséggel, hogy a Fidesz-MDF kicsit átlag felett, míg az SZDSZ a bejutási küszöb alatt szerepet. Elmondható, hogy a klaszter területileg szórtan, fóként vidéki területeket ölel fel, illetve főként dunántúli jobboldali bázisú területeken található urbánus kerületeket (Györ, Nagykanizsa, Szombathely, Zalaegerszeg stb.) foglal magába. Kijelenthető, hogy ez a csoport a leginkább vegyes jellegü földrajzi és társadalmi szempontból.

Összegezve elmondható, hogy a 2002-es parlamenti választások eredményei átrajzolták a kilencvenes évek választói magatartásának földrajzi sajátosságait. Vidéken kialakult egy éles térbeli törésvonal a jobboldali és baloldali tömörülések között, míg a fóvárosban és agglomerációjában a szocialisták és a liberálisok is erős szavazóbázist építettek ki. Az országos átlaghoz hasonlatos kerületek magas száma ugyanakkor arra engedett következtetni, hogy 2002-ben még nem volt sok általánostól határozottan eltérő pártpreferenciával rendelkező terület.

\subsubsection{A 2006-os országgyülési választások földrajzi jellemzői}

A négy évvel korábban kialakult választási földrajzi kép 2006-ban stabilizálódott annak ellenére is, hogy az MDF külön indult a választásokon, a Fidesz szövetségese a KDNP lett és immár négy lista jutott be a parlamentbe (KORKUT, U. 2007). A rendszerváltozásnál létrehozott választási rendszer ötödik próbáján 67,83\%-os részvétel mellett az MSZP 43,21\%-os rekordmagas eredménnyel nyerte meg ismét a választásokat. A Fidesz-KDNP lemaradva 42,03\%-ot ért el, az SZDSZ 6,5\%-os, míg az MDF 5,04\%-os teljesítményével a bejutási küszöböt éppen átlépte. Nem történt kormányváltás és első ízben folytathatta a regnáló koalíció a munkáját. A 176 egyéni mandátumból az MSZP önállóan 98, a liberálisokkal közösen hatot, míg a SZDSZ önállóan hármat szerzett meg. A Fidesz-KDNP 68 egyéni helyhez jutott, valamint egy civil egyesület is sikeresen szerzett mandátumot. A pártlistás voksok alapján számolt hierarchikus és k-közép klaszterelemzés azt mutatta ki, hogy a stabil és biztos MSZPSZDSZ győzelem ellenére a 2002-es térszerkezet némi módosulásokon ment át, miközben a térbeli törésvonalak hangsúlyosabbak lettek (6. ábra, 8. táblázat). 
A vizsgálat során négy markáns térbeli jellegzetességgel rendelkező klasztert sikerült kimutatni. Az első, „MSZP bázis” klaszterbe 49 olyan választókerület került, ahol 2006-ban a szocialisták többnyire átlépték az 50\%-os támogatottsági küszöböt, az SZDSZ átlagon felül, míg az MDF átlag alatt szerepet. Ezeken a területeken a Fidesz-KDNP súlyos vereséget szenvedett, hiszen támogatottságuk itt volt a legrosszabb és több mint 15 százalékponttal lemaradtak az MSZP listájától. Földrajzi szempontból jelentős átrendeződés itt nem ment végbe, néhány változástól eltekintve szinte ugyanazok a területek lettek stabil baloldali bázisok, amelyek 2002-ben is voltak. Annyi változás írható le, hogy kettővel több kerület került ebbe a csoportba, és a szocialisták ezeken a területeken tudtak erösíteni a négy évvel korábbi eredményeikhez képest.

6. ábra: A 176 választókerület politikai klaszterei és klaszterközéppontjai 2006-ban

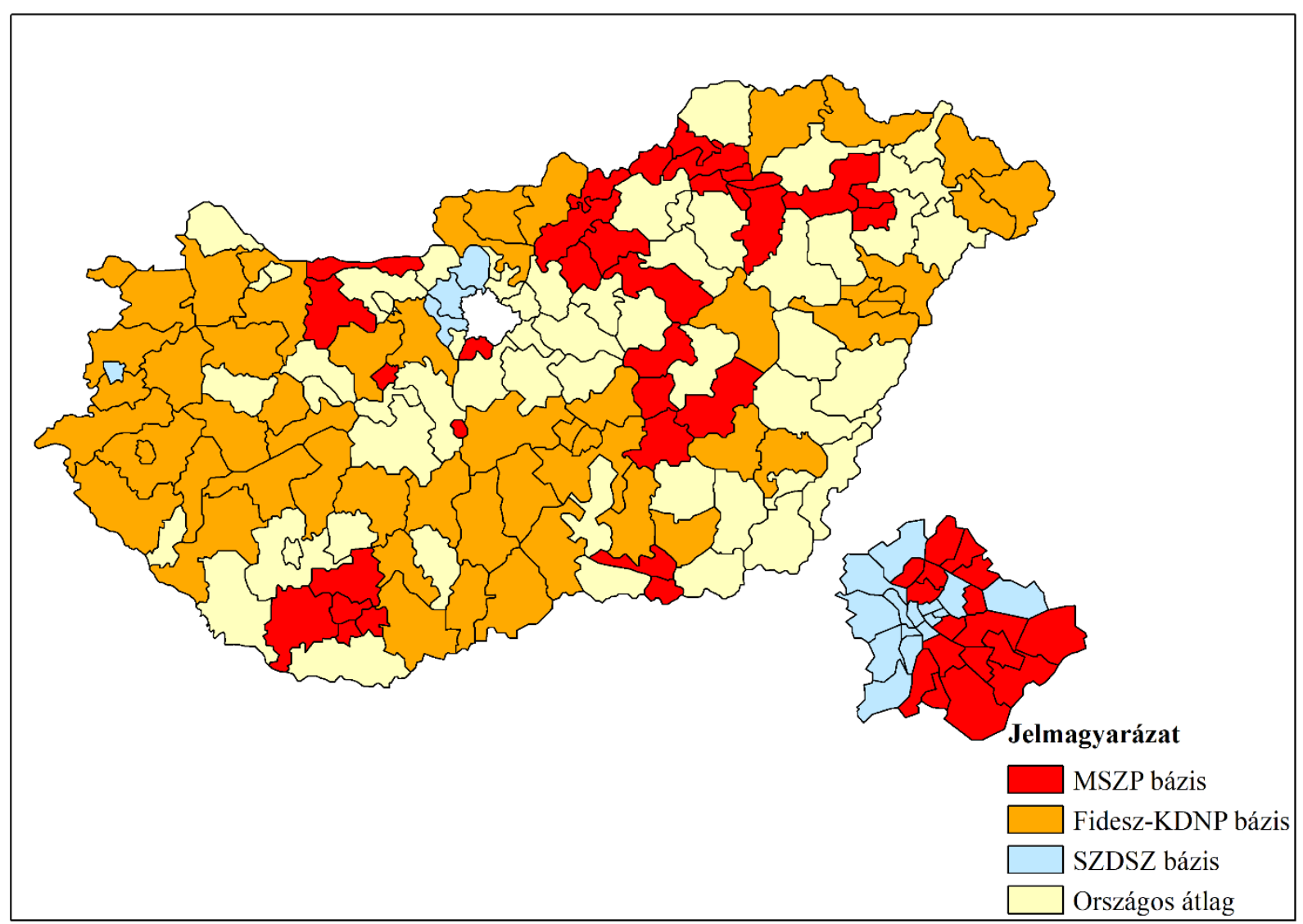

Forrás: Nemzeti Választási Iroda adatai alapján saját számítás és szerkesztés

8. táblázat: Magyarország 2006-os választási földrajzi klaszterei a középpontokkal

\begin{tabular}{ccccc}
\hline Klaszterek és középpontjai & $\begin{array}{c}\text { MSZP } \\
\text { Bázis (49) }\end{array}$ & $\begin{array}{c}\text { Fidesz- } \\
\text { KDNP bázis } \\
(53)\end{array}$ & $\begin{array}{c}\text { SZDSZ } \\
\text { bázis } \\
(19)\end{array}$ & $\begin{array}{c}\text { Országos } \\
\text { Átlag (55) }\end{array}$ \\
\hline MSZP & 51,35 & 37,24 & 36,98 & 44,49 \\
Fidesz-KDNP & 33,16 & 50,46 & 40,19 & 42,65 \\
SZDSZ & 7,37 & 4,19 & 13,76 & 4,81 \\
MDF & 4,83 & 5,14 & 5,44 & 4,83 \\
\hline
\end{tabular}

Forrás: Nemzeti Választási Iroda adatai alapján saját számítás és szerkesztés 
A második, „Fidesz-KDNP bázis” csoportba 53 választókerület került besorolásra. Vegyes, de markánsabban vidéki területek alkották ezt a csoportot, ahol a Fidesz-KDNP 50\%os támogatottságot tudhatott maga mögött, a szocialisták nagyon átlag alatt végeztek, valamint a liberálisok is itt teljesítettek a legrosszabbul, miközben az MDF elérte a bejutási küszöböt. Földrajzi szempontból jelentős változás, hogy Kecskemét és Debrecen mellett sokkal több vidéki terület lett stabilabban jobboldali, hiszen 2002 óta 24 választókerület került át az átlagos klaszterből Fidesz-KDNP bázissá. Ez a földrajzi folyamat visszatükrözi a jobboldal ellenzékben végzett vidéki mozgósító programjainak hatásait (pl. polgári körök, stratégiai partnerségek gazdákkal és vállalkozókkal).

A harmadik, „SZDSZ bázis” klaszterébe 19 választókerületet lehetett besorolni. Ez a klaszter a korábbi átlagához képest jelentően átalakult, hiszen az SZDSZ itt erősíteni tudott, országos értékének kétszeresét érte el, miközben az MDF is ezekben a választókerületetekben szerepelt a legjobban. Változás a négy évvel korábbi eredményekhez képest az, hogy a FideszKDNP megelőzte és legyőzte az MSZP-t ezekben a kerületekben. Míg a Fidesz-KDNP alig szerepelt országos eredménye alatt, az MSZP jelentősen visszaesett és mélyen átlagon alul mutatkozott. Földrajzi szempontból keveset változott a kép, hiszen tartósan megmaradtak liberális bázisnak a főváros belvárosi és budai részei és Budapest északi és nyugati agglomerációja, amihez kivételesen csatlakozott Szombathely választókerülete is.

A negyedik, „Országos átlag” csoportba 55 választókerület került besorolásra. A klaszter ismét szinte tökéletesen leképezte az országos végeredményt, annyi különbséggel, hogy az MSZP kicsit átlag felett, míg az SZDSZ és az MDF a bejutási küszöb körül szerepelt. Elmondható, hogy a klaszter területileg ismét szórtan, fóként vidéki területeket foglalt magába. A fó változás, hogy jelentősen zsugorodott azon kerületek száma, ahol az országos eredmények tükröződtek vissza.

Összegezve a 2006-os parlamenti választások eredményei megerősítették a négy évvel korábbi térszerkezetet, azonban két jellemző változás már előre vetítette a konzervatív oldal későbbi sikerét a vidéki területeken. A Fidesz-KDNP bázis jelentősen megnövekedett a vidéki területeken, hovatovább a liberális fellegvárakban már az MSZP-t is legyőzték. A szocialisták a hanyatló iparvidékeken és a fővárosban tudták jelentősen felülmúlni saját átlagukat, a vidéki fellegváraiban is erősödtek, viszont térben nem tudtak új területeket meghódítani. Végezetül a jobboldal-baloldal közötti törésvonal erösödését mutatta, hogy a négy évvel korábbi állapothoz képest az országos átlaghoz konvergáló kerületek száma jelentősen csökkent.

\subsubsection{A 2010-es országgyülési választások földrajzi jellemzői}

A 2010 óta eltelt három országgyülési választás a jelenleg is kormányzó Fidesz-KDNP politikai dominanciáját jelezte. A korábban kétpólusú pártstruktúra felbomlása markáns választásföldrajzi átrendeződéseket indított el és a felszínen látható állandóság mögött a három országgyülési választás tapasztalatai alapján jelentős térbeli átrendeződés figyelhető meg.

Az eredmények alapján megállapítható, hogy a 2002-re megszilárdult kétpólusú pártstruktúra jelentősen átalakult. Az első fordulóban a Fidesz-KDNP 64,38\%-os választási részvétel mellett 52,73\%-os szavazatarányt ért el, és ezzel a képviselöi mandátumok több mint kétharmadát szerezte meg az országgyülésben. Az MSZP a 2006-os 43,21\% helyett 19,3\% -os eredményével középpárttá zsugorodott, míg az 1990-es rendszerváltó választásokat még meghatározó MDF és SZDSZ egyaránt kiesett a parlamentböl. A nemzeti radikális Jobbik 16,67\%-kal, míg a zöldpárti LMP 7,48\%-kal került be az országgyülésbe. A nyugati demokráciákkal szembeni megkésettségre utal, hogy Magyarországon csak viszonylag későn, 
2010-re erősödtek meg a materiális-posztmateriális törésvonal mentén szerveződő pártok (SZABÓ B. 2013). A 176 egyéni mandátumból a Fidesz-KDNP mellett csak kettőt sikerült megszereznie az MSZP-nek és egyet egy függetlennek, viszont a hierarchikus és k-közép klaszterelemzés során a stabil konzervatív győzelem ellenére is markáns választási földrajzi eltérések rajzolódtak ki (7. ábra, 9. táblázat). A 2002-es és 2006-os eredményekhez képest a vizsgálat során öt térbeli jellegzetességgel rendelkezö klasztert sikerült kimutatni.

\section{7. ábra: A 176 választókerület politikai klaszterei és klaszterközéppontjai 2010-ben}

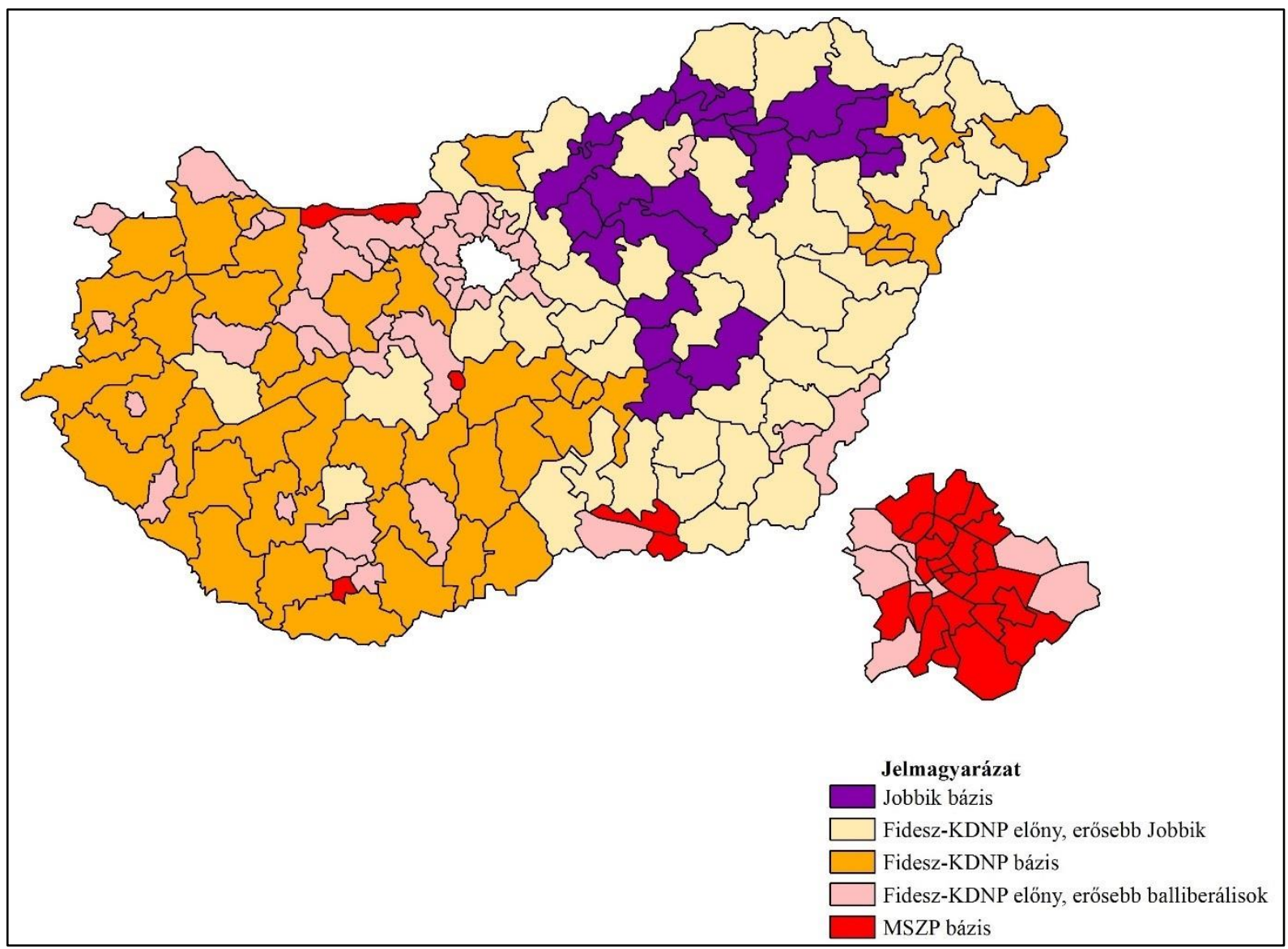

Forrás: Nemzeti Választási Iroda adatai alapján saját számítás és szerkesztés

Az első, „Jobbik bázis” klaszterbe 23 olyan választókerület került, ahol a választói magatartás folytonossága korábban is meglehetősen instabil volt (KOVACs Z. - DiNGSDALE, A. 1998), és korábban jellemzően népszerü volt a baloldal. Megállapítható, hogy míg a MIÉP főleg Budapesten és a nagyvárosokban szerepelt jól, addig 2010-től a Jobbik egyértelmüen vidéken volt népszerübb, így a két párt közötti folytonosság földrajzi szempontból sem támasztható alá. A csoportot alkotó választókerületekben főként az állandósuló gazdasági problémák és a gyakori roma-magyar konfliktusok járultak hozzá a nemzeti radikálisok megerősödéséhez. Ezen kerületekben a Jobbik az országos átlagához képest jelentősen túlteljesített, míg a FideszKDNP mélyen saját átlaga alatt szerepelt. Az MSZP átlagon felül, az LMP pedig ez alatt szerepelt. 
9. táblázat: Magyarország 2010-es választási földrajzi klaszterei a középpontokkal

\begin{tabular}{cccccc}
\hline Klaszterek és középpontjai & $\begin{array}{c}\text { Jobbik } \\
\text { Bázis (23) }\end{array}$ & $\begin{array}{c}\text { Fidesz- } \\
\text { KDNP } \\
\text { előny, } \\
\text { erősebb } \\
\text { Jobbik (40) }\end{array}$ & $\begin{array}{c}\text { Fidesz- } \\
\text { KDNP } \\
\text { bázis } \\
(41)\end{array}$ & $\begin{array}{c}\text { Fidesz-KDNP } \\
\text { előny, erösebb } \\
\text { balliberálisok } \\
(43)\end{array}$ & $\begin{array}{c}\text { MSZP } \\
\text { bázis (29) }\end{array}$ \\
\hline Fidesz-KDNP & 43,73 & 54,52 & 61,39 & 51,95 & 44,13 \\
MSZP & 20,35 & 15,29 & 15,41 & 20,62 & 26,50 \\
Jobbik & 26,11 & 21,97 & 14,59 & 13,06 & 11,60 \\
LMP & 5,23 & 4,15 & 5,42 & 9,31 & 12,37 \\
\hline
\end{tabular}

Forrás: Nemzeti Választási Iroda adatai alapján saját számítás és szerkesztés

A második, „Fidesz-KDNP előny, erősebb Jobbik” csoportba 40 választókerület került. Olyan, többnyire vidéki területek alkották ezt a csoportot, ahol a Fidesz-KDNP korábban nem szerepelt kifejezetten sikeresen (Pl: Heves, Gyöngyös, Kunszentmárton, Mezőtúr), viszont az MSZP térvesztésével elöre tört a jobboldal, amit jelez, hogy saját országos átlagához képest itt a Jobbik is kimutathatóan jól szerepelt.

A harmadik, „Fidesz-KDNP bázis” klaszterébe 41 választókerület került. Itt a konzervatív kormánypártok korábban is jól szerepeltek: Debrecen és Kecskemét városát leszámítva fóként a Dunántúl vidéki kerületei tartoznak ide, ahol az országos átlaghoz képest kilenc százalékponttal szerepelt jobban a jelenlegi kormányzó pártszövetség, miközben valamennyi ellenzéki párt átlagon alul teljesített. Ennek fényében a Dél-Alföldön a kisgazda, a Dunántúlon a vidéki stabil konzervatív, valamint a keleti országhatár menti kisvárosokban és falvakban a keresztény hagyományok szerepe továbbra is hathatott a pártpreferenciákra.

A negyedik, „Fidesz-KDNP előny, erősebb balliberálisok” csoportba 43 választókerület került. Túlnyomóan nagyvárosi (pl. Buda), vagy a Budapest agglomerációját felölelő, illetve dunántúli urbánus kerületek (Győr, Nagykanizsa, Szombathely, Zalaegerszeg stb.) tartoztak ide. E klaszter is jelzi, hogy 2010-re a baloldal szavazóbázisa föként az urbanizált térségekbe szorult vissza, hiszen ezekben a választókerületekben közel sem esett vissza annyira a támogatottságuk 2006-hoz képest, mint a döntően vidéki kerületekben.

Az ötödik, „MSZP bázis” klaszterbe 29 választókerület volt besorolható. Ezekről elmondható, hogy hasonló földrajzi jegyekkel bírnak, mint az előző klaszter, de itt egyértelműbb az MSZP beágyazottsága és a szocialista szavazók térbeli koncentrációja. Ezeken a területeken az országos átlaghoz viszonyítva a kormánypártok kilenc, míg a Jobbik öt százalékponttal gyengébben teljesített, valamint a liberális hagyományokat is átörökítő zöldek messze itt voltak a legnépszerübbek. A klaszterelemzés választókerületi szinten is részben alátámasztja a korábban Budapest kisebb szavazókörzeteiben kimutatott eredményeket (SZABÓ B. 2013, IGNÁCZ K. - SZABÓ B.2014), miszerint a Jobbik 2010-ben inkább a szegényebb (és korábban jellemzően baloldali preferenciájú) térségekben tudott nagyobb népszerüségre szert tenni, míg az LMP inkább a jómódú területeken szerepelt sikeresen.

Összegezve megállapítható, hogy 2006-hoz képest 2010-ben a választói magatartás markáns térbeli átrendeződése volt tapasztalható. A hagyományosan baloldali szavazóbázist jelentő vidéki válságtérségekben megerősödött a Jobbik, miközben az MSZP visszaszorult. Emellett a hagyományos társadalmi különbségek mellett kirajzolódtak a materialistaposztmaterialista törésvonal mentén szerveződő pártok térbeli sajátosságai is. Míg a Jobbik 
döntően vidéki, gazdaságilag leszakadó területeken vált népszerüvé, addig az LMP a vidéki nagyvárosokban és a fóvárosban, illetve agglomerációjában ért el önmagához képest kiugró eredményeket. A 2010-es választásokon a Fidesz-KDNP országosan átütő győzelmet aratott, és felhatalmazást kapott a választási rendszer és a kerületi beosztás átalakítására is.

\subsubsection{A 2014-es országgyülési választások földrajzi jellemzői}

Az új választási rendszer a 2014-es országgyülési választásokon mutatkozott be először. A kormányzó Fidesz-KDNP pártszövetség 61,73\%-os választási részvétel mellett 44,87\%-os eredményt ért el, s bár csaknem nyolc százalékpontot veszített négy évvel korábbi eredményéhez képest, ennek ellenére ismét kétharmados többséget szerzett az országgyủlésben. Az ellenzéki oldalon kialakult összefogás, az MSZP-Együtt-DK-PM-MLP és a Jobbik is növelni tudta támogatottságát (25,57\%, ill. 20,22\%), míg az LMP a - korábbi pártszakadást átvészelve 5,34\%-os országos listás eredménnyel ismét bekerült a parlamentbe. Az országos végeredmények alapján megállapítható, hogy az átrajzolt választókerületekben stabilizálódott a 2010-ben kialakult pártstruktúra. A 106 egyéni mandátumból csak 10-et szerzett meg a baloldali összefogás, viszont markáns földrajzi eltérések és átrendeződések is kialakultak az új beosztásban (8. ábra, 10. táblázat).

Az első, úgynevezett „MSZP-Együtt-DK-PM-MLP bázis” klaszterbe 17 többnyire urbánus, a főváros pesti oldalához (pl. Angyalföld), ill. hagyományosan baloldali nagyvárosokhoz (pl. Szeged), iparvárosokhoz (pl. Miskolc) köthető kerületek alkották. Ez megerősíti a 2010-ben elindult térbeli átrendeződési folyamatot, amikor a baloldali és liberális pártok egyre inkább az urbánus területekre szorultak vissza. A korábbi, az 1990-es évekre jellemző viszonylagos kiegyenlített urbánus-rurális szavazatmegoszlás a múlté (KovÁcs Z. 2000), amit felerősített a szocialista párt markáns baloldali jegyeinek oldódása és liberális pártokkal, pártkezdeményekkel való közös indulása. Ezen felül az új választókerületi beosztás Budapesten és a vidéki nagyvárosokban (pl. Baranya megye 1-es, 2-es, Csongrád megye 1-es, Szabolcs-Szatmár-Bereg megye 1-es, 2-es) a hagyományosan baloldali-liberális szavazókat erőteljesen koncentrálta, ami a jobboldali formációk számára elönyt jelentett 2014-ben.

A második, „Fidesz-KDNP bázis” elnevezésű csoportba 31 olyan választókerület került, ahol a kormánypártok előnye a többi párttal szemben nagyobb volt, mint az országos átlag. Ebben a csoportban egy-egy kecskeméti, illetve debreceni területet leszámítva föként vidéki választókerületeket találunk. Ezekben a kerületekben a Jobbik átlagon felül, míg az ellenzéki összefogás és az LMP gyengébben szerepelt. A voksok földrajzi eloszlásából arra következtethetünk, hogy 2010-hez képest egyfajta térbeli átrendeződés ment végbe, hiszen a Fidesz-KDNP pártszövetség korábban a Dunántúlon, míg 2014-ben a Tiszántúl kerületeiben szerepelt saját magához képest is kimagaslóan.

A harmadik, „Fidesz-KDNP előny, erősebb balliberálisok” csoportba 13, többnyire jómódú budai és a főváros nyugati agglomerációjához tartozó választókerület, valamint az egyik szegedi és székesfehérvári, illetve a szombathelyi választókerület tartozott. A többi klasztertől való éles elkülönülést az adja, hogy a viszonylag erősebb balliberálisok mellett az LMP együttvéve itt sokkal nagyobb támogatottságot tudhatott maga mögött, mint az összes többi klaszterben.

A negyedik, „Jobbik bázist” képező klaszterbe 16 választókerület került. 2010-hez képest változás, hogy néhány korábbi szocialista fellegvárban (pl. Dunaújváros, Nagykanizsa) sikerült jelentős számú voksot elhódítani a Jobbiknak. Ezeken a területeken hagyományosan átlagon aluli volt a Fidesz-KDNP támogatottsága, miközben az MSZP a szivárványos (Együtt-DK- 
PM-MLP) koalíció jóvoltából részben stabilizálni tudta bázisát. Ezekben a kerületekben így kiélezett, hárompólusú verseny volt tapasztalható a mandátumokért, ami néhol a részvételi arányokat is megemelte.

\section{8. ábra: A 106 választókerület politikai klaszterei és klaszterközéppontjai 2014-ben}

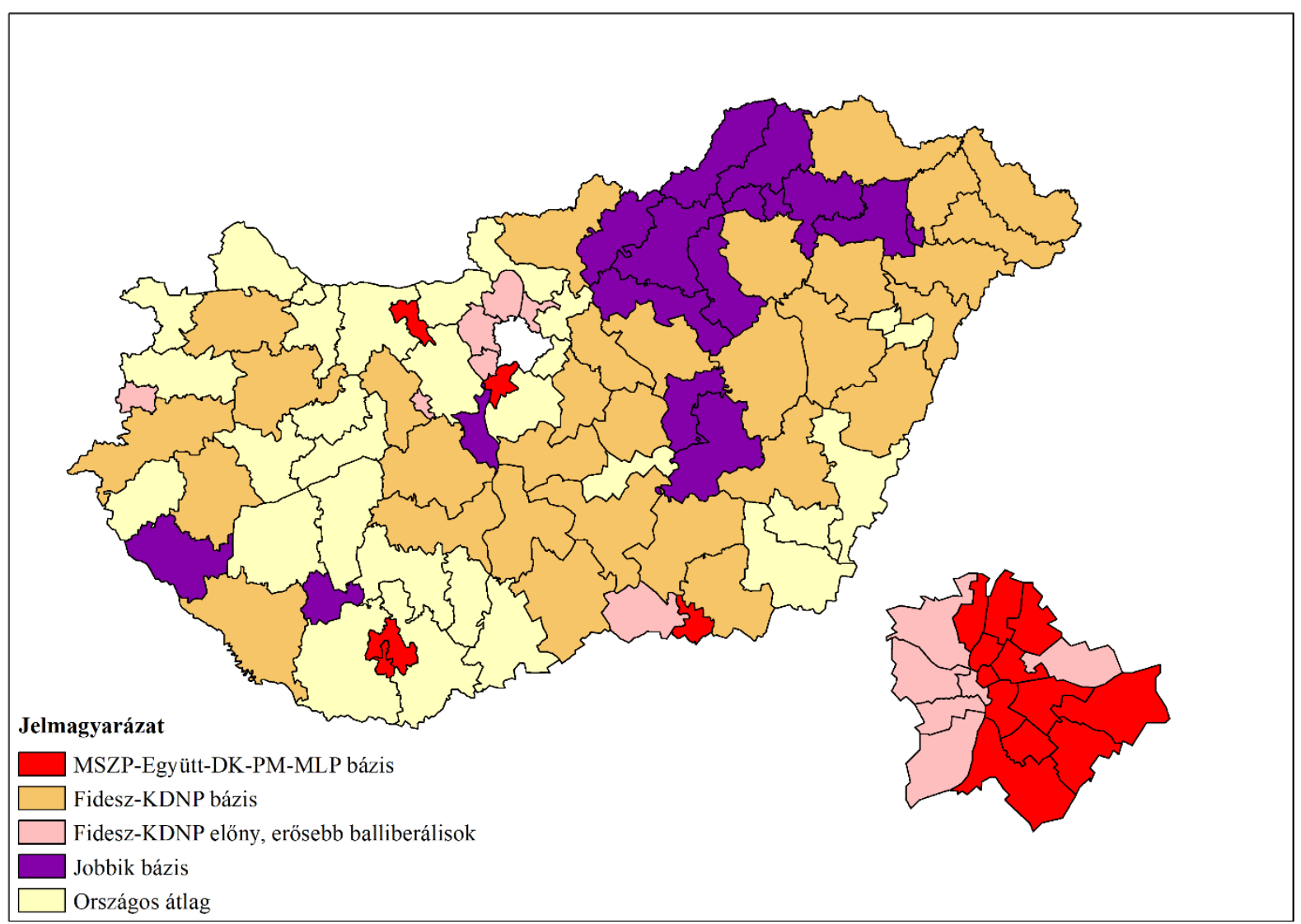

Forrás: Nemzeti Választási Iroda adatai alapján saját számítás és szerkesztés

10. táblázat: Magyarország 2014-es választási földrajzi klaszterei a középpontokkal

\begin{tabular}{|c|c|c|c|c|c|}
\hline $\begin{array}{l}\text { Klaszterek és } \\
\text { középpontjai }\end{array}$ & $\begin{array}{c}\text { MSZP- } \\
\text { Együtt-DK- } \\
\text { PM-MLP } \\
\text { bázis (17) }\end{array}$ & $\begin{array}{l}\text { Fidesz- } \\
\text { KDNP } \\
\text { bázis (31) }\end{array}$ & $\begin{array}{c}\text { Fidesz- } \\
\text { KDNP előny, } \\
\text { erösebb } \\
\text { balliberálisok } \\
\text { (13) }\end{array}$ & $\begin{array}{c}\text { Jobbik } \\
\text { bázis (16) }\end{array}$ & $\begin{array}{l}\text { Országos } \\
\text { átlag (29) }\end{array}$ \\
\hline Fidesz-KDNP & 36,35 & 48,86 & 43,83 & 38,22 & 46,67 \\
\hline $\begin{array}{c}\text { MSZP-Együtt-DK- } \\
\text { PM-MLP }\end{array}$ & 36,27 & 19,08 & 31,78 & 26,20 & 24,13 \\
\hline Jobbik & 15,05 & 25,34 & 12,17 & 28,11 & 20.25 \\
\hline LMP & 8,17 & 3,34 & 8,77 & 3,62 & 5,17 \\
\hline
\end{tabular}

Forrás: Nemzeti Választási Iroda adatai alapján saját számítás és szerkesztés 
Az ötödik, „Országos átlag” klaszterbe 29 választókerület tartozik. Ezt a csoportot fóként a Budapesten kívüli, jobboldali nagyvárosi fellegvárak (Debrecen, Győr) urbánus, valamint korábban nem kifejezetten jobboldali, de nagyobb rurális háttérrel rendelkező választókerületek alkották. Mivel földrajzi szempontból igen kevert típusúak ezek a kerületek (pl. debreceni nagyvárosi településegyüttes vagy Marcali térsége), ezért az országos eredményekhez is ez a csoport hasonlít a leginkább.

A 2014-es választások földrajzi tapasztalatait összegezve több megállapítás is tehető. Egyrészt fennmaradt a térbeli tagoltság Budapesten és agglomerációjában. A pesti oldal hagyományosan baloldali, míg a budai kerületekben, valamint a jómódú elővárosi körzetekben a Fidesz-KDNP szerepelt jobban. Ezeken a területeken érezhetően erősebb az LMP és gyengébb a Jobbik. Vidéken az összetett gazdasági és társadalmi problémákkal rendelkező periférikus területeken (pl. kazincbarcikai, kisvárdai, ózdi választókerület) tartósan népszerü a Jobbik, míg néhány kifejezetten nagyvárosi kerületben (pl. a tatabányai, mindkét pécsi és a szegedi 1-es) erős maradt a baloldal. A mezővárosias alföldi, és különösen a tiszántúli választókerületekben a Fidesz-KDNP dominált, míg az urbanizált földrajzi területeken kisebb volt az elönyük.

\subsubsection{A 2018-as országgyülési választások földrajzi jellemzői}

A rendszerváltozás óta a 2018-as országgyülési választás több szempontból is különös jelentőséggel bírt, hiszen több korábban kialakult összefüggésre is rácáfoltak az eredmények. A választások során a napközbeni részvételi eredmények arra utaltak, hogy magas az érdeklődés, ami minden politikai oldalt további mozgósításra ösztönzött. Ebből adódóan a magas választási aktivitás egész nap jellemző volt, így összességében 70,22\%-os lett a részvételi arány. Megfordult a 2002-es parlamenti választások óta csökkenő részvételi hajlandóság, és ezen a voksoláson volt a rendszerváltozást követő második legmagasabb részvétel. 2014-hez képest 8,49 százalékpontos emelkedés történt a részvételben, viszont ez választókerületi bontásban nem volt egyenletes.

A kormányzó Fidesz-KDNP 49,27\%-os eredményt ért el az országos listán, ami több mint négy 4 százalékpontos javulást jelentett a 2014-hez képest. A balliberális összefogás szétesése után a második legtöbb listás szavazatot elnyert párt a Jobbik lett, azonban a 19,06\% os listás arányával így is több mint egy százalékponttal kevesebbet ért el 2014-hez képest. A választás legnagyobb vesztese a balliberális oldal lett, hiszen a korábbi közös lista helyett most az MSZP-PM 11,91\%-os, míg a DK a parlamenti küszöb átugrásával 5,38\%-os eredményt ért el, ami messze elmaradt a korábbi várakozásoktól. Az Együtt még az 1\%-os határt sem érte el, amivel meg is szünt. A 2018-as országgyülési választásokon a kormányzópártok mellett az LMP tudta növelni abszolút és fajlagos támogatottságát, hiszen 7,06\%-os országos listás eredménnyel zárt, ami másfél százalékpontos javulást jelentett 2014-hez képest.

Az induló pártok magas száma 2018-ban is jellemző volt, sőt nagyobb méreteket öltött, mint négy évvel korábban, hiszen 18 helyett már 23 párt volt az országos listán. Ezt tetézte az ellenzéki politikai erők széthúzása, ez a szavazatok jelentős széttartásához vezetett. Míg 2014ben még a szavazatok 3,63\%-a, addig 2018-ban már 7,32\%-a került olyan pártokra, akik végül nem jutottak be az országgyülésbe. Az országos eredmények alapján megállapítható, hogy a kormányzó pártok megerősödtek, az ellenzék pedig súlyos vereséget szenvedett. 
Ha földrajzi szempontból vizsgáljuk a területi különbségeket, a város-vidék társadalmi törésvonal további erősödését és ennek politikai következményeit láthatjuk. Folytatódott az a folyamat, hogy a balliberális pártok és az új politikai formációk szavazataik jelentős részét a nagyvárosokban szerezték, de most itt jelentősebb rivalizálás is kialakult a támogatottságért. Így a nagyvárosokban elaprózódott a szavazat, ami mindenképpen gyengítette a baloldali és liberális pártok esélyeit. Ezzel szemben vidéken egyértelmü volt a Fidesz-KDNP előnye, a Jobbikon kívül a többi ellenzéki párt is súlytalanná vált. Ez a folyamat biztos szavazóbázist hozott a jobboldalnak, így a szavazatok széttartása sem okozott gondot.

Az előző korszakkal szemben 2018-ra felerősödött a taktikai szavazás jelensége. A taktikai szavazás Nyugat-Európában és az angolszász területeken jellemző (CoX, G. W. 1997, Johnston, R. - PATTiE, C. 2011a,b), s Magyarországon korábban nem volt tudatosan és tömegesen jelentkező választói magatartás, csak az egyfordulós új választási eljárás megalkotásával kezdett megerösödni. Ezért a nagyvárosokban részben müködő taktikai szavazás azt eredményezte, hogy a 106 egyéni mandátumból 15-öt szerzett meg az ellenzék, ami öt hellyel több, mint négy évvel korábban. Ez is rámutat a térbeliség szerepének felértékelődésére, amikor a választási rendszerek képviselői helyekké alakítják a szavazatokat. A hierarchikus és K-közép klaszterelemzés eredményeit kartogramra téve és értékelve megállapítható, hogy a korábbi markáns választási földrajzi eltérések elmosódtak, miközben a város-vidék választási törésvonal kiéleződött (9. ábra, 11. táblázat).

\section{9. ábra: A 106 választókerület politikai klaszterei és klaszterközéppontjai 2018-ben}

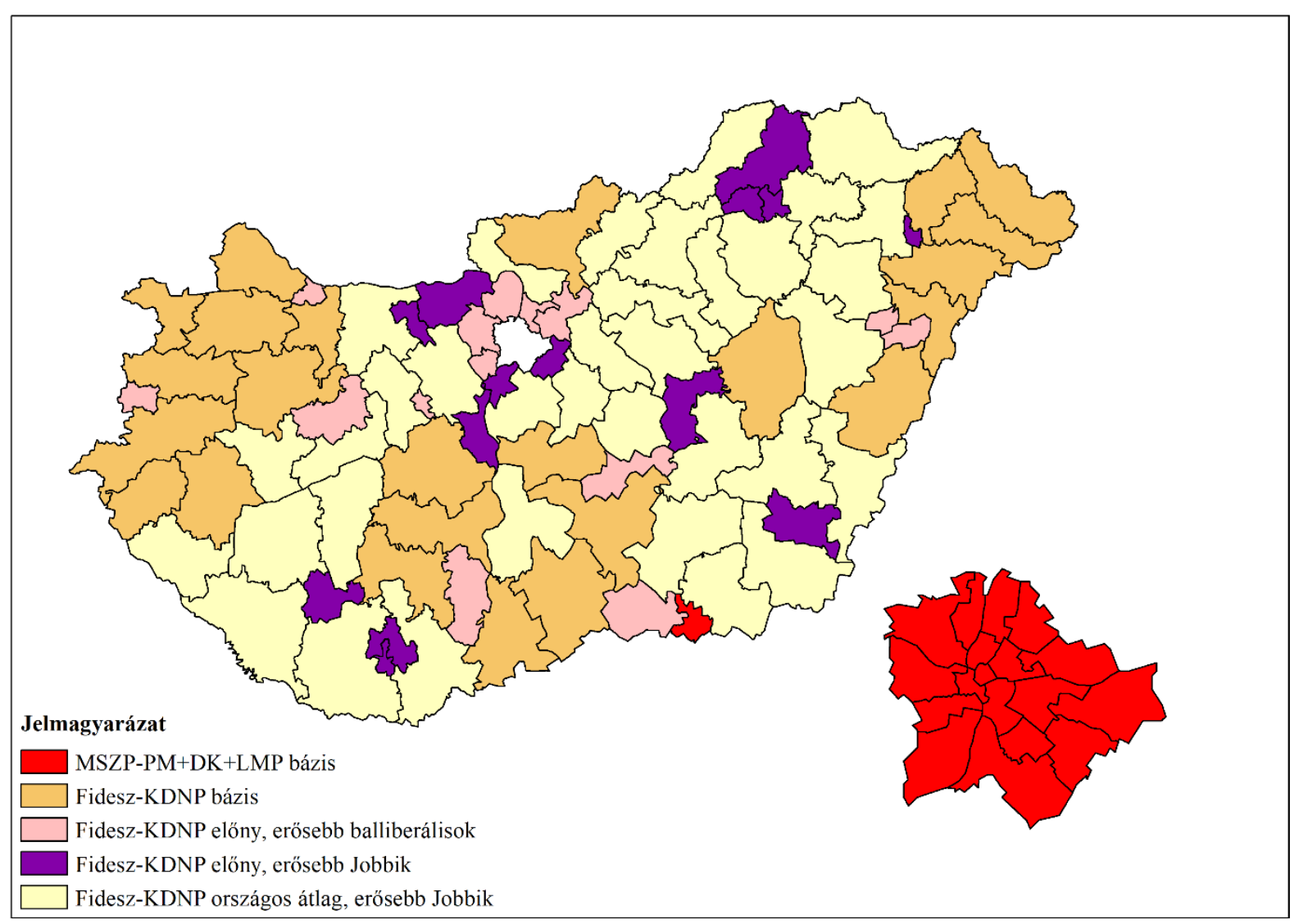

Forrás: Nemzeti Választási Iroda adatai alapján saját számítás és szerkesztés 
11. táblázat: Magyarország 2018-as választási földrajzi klaszterei a középpontokkal

\begin{tabular}{cccccc}
\hline $\begin{array}{c}\text { Klaszterek és } \\
\text { középpontjai }\end{array}$ & $\begin{array}{c}\text { MSZP- } \\
\text { PM+DK+LMP } \\
\text { bázis (19) }\end{array}$ & $\begin{array}{c}\text { Fidesz- } \\
\text { KDNP } \\
\text { bázis (24) }\end{array}$ & $\begin{array}{c}\text { Fidesz- } \\
\text { KDNP előny, } \\
\text { erösebb } \\
\text { balliberálisok } \\
(14)\end{array}$ & $\begin{array}{c}\text { Fidesz-KDNP } \\
\text { előny, erösebb } \\
\text { Jobbik (14) }\end{array}$ & $\begin{array}{c}\text { Fidesz-KDNP } \\
\text { országos } \\
\text { átlag, erősebb } \\
\text { Jobbik (35) }\end{array}$ \\
\hline Fidesz-KDNP & 38,09 & 56,51 & 46,68 & 41,40 & 49,95 \\
Jobbik & 13,07 & 19,99 & 16,31 & 23,70 & 23,75 \\
MSZP-PM & 18,20 & 9,08 & 12,51 & 13,54 & 10,38 \\
LMP & 10,84 & 5,06 & 9,84 & 7,37 & 5,38 \\
DK & 8,47 & 3,84 & 5,81 & 6,52 & 4,48 \\
\hline
\end{tabular}

Forrás: Nemzeti Választási Iroda adatai alapján saját számítás és szerkesztés

Az első úgynevezett „MSZP-PM+DK+LMP bázis” klaszterbe 19 kifejezetten urbánus terület került, hiszen a fóváros mellett Szeged választókerülete alkotja ezt a csoportot. Itt a balliberális pártok a zöldekkel közösen jelentős támogatottságot élveztek és győzelmi esélyeik is nagyok voltak. 2014-hez képest átrendeződést mutat, hogy a főváros budai kerületei is ide kerültek, hiszen a Fidesz-KDNP támogatottsága ezen a területen nem növekedett, sőt még néhány helyen csökkent is a négy évvel korábbi eredményhez képest. Ez viszonylag új jelenség, hiszen a fóváros budai oldala hagyományos bástyája volt a jobboldalnak, de 2018-ra már a korábbi előnyök jórészt eltűntek. A főváros mellett Csongrád megye 1-es kerülete került ebbe a csoportba, ami jórészt az új beosztás eredménye, hiszen Szegeden a hagyományosan baloldali-liberális szavazókat erőteljesen koncentrálta az újabb térfelosztás.

A második, „Fidesz-KDNP bázis” elnevezésű csoportba 24 olyan választókerület került, ahol a kormánypártok támogatottsága megkérdőjelezhetetlen és az ellenzéknek nem volt győzelmi esélye. Ebben a csoportban találhatunk az osztrák határhoz közeli gazdaságilag fejlettebb vidéki választókerületeket éppúgy, mint fejletlenebb külső és belső perifériát (pl. Berettyóújfalu-, Nyírbátor-, Sárbogárd kerülete stb.) is. Ennek a klaszternek a térbeli elrendeződése visszatükrözi a 2000-es évek beosztásán alapuló területi autokorreláción alapuló szomszédsági elemzést (MÉSzÁROS, J. et al. 2007), ami jelzi a választói magatartás bizonyos mértékü folytonosságát. Azonban a korábbiakhoz képest közös jellemzője ezeknek a választókerületeknek, hogy markánsabban vidékies jellegủek. Jellemző választásföldrajzi tulajdonság, hogy ebben a klaszterben nem jutott volna parlamentbe az MSZP-PM és a DK listája sem.

A harmadik, „Fidesz-KDNP előny, erősebb balliberálisok” csoportba 14, többnyire jómódú, Budapest nyugati és északi agglomerációjához tartozó, valamint a megyeszékhelyek urbanizált (pl. debreceni 1-es, 2-es, székesfehérvári 1-es) választókerületei tartoztak. A többi klasztertől való éles elkülönülést az adja, hogy az átlagon felüli balliberálisok mellett a zöldek is nagyobb támogatottságot tudhatnak maguk mögött és a fóváros mellett itt vannak $10 \%$ közelében. A föváros mellett ezekben a kerületekben alakulhat ki leginkább verseny a kormánypártok és az ellenzék között a jövőben.

A negyedik, „Fidesz-KDNP előny, erősebb Jobbik” elnevezésü klaszterbe 14 választókerület került. Az előző klaszterhez hasonlóan ezek a kerületek is inkább városias vonásokkal rendelkeznek és a Fidesz-KDNP támogatottsága az országos átlag alatt maradva, közelíti a fővárosi arányokat. A teljes ellenzék támogatottsága magasabb az országos átlagnál. 
2014-hez képest változás a klaszterbe tartozó kerületekben, hogy a Jobbik néppárttá válása miatt elmosódni látszik a korábbi balliberálisok és nemzeti radikálisok közötti éles határvonal. Így néhány, korábban inkább a balliberális oldalt támogató urbánusabb területen sikerült a Jobbiknak növelni a támogatottságát. Ebböl adódóan megállapítható, hogy itt teljes ellenzéki összefogással reális esély lett volna a kormányzópártok legyőzésére.

Az ötödik, „Fidesz-KDNP országos átlag, erősebb Jobbik” klaszterbe 35 vegyes, jellemzően inkább vidéki választókerület tartozik. A kormányzópárt itt országos átlagteljesítménye közelében van és a 2014-es Jobbik bázis klaszterből is átkerült ide sok vidéki kerület. Ez is alátámasztja, hogy a Jobbik támogatottságában jelentős földrajzi átrendeződést tapasztalunk 2014-hez képest. Amíg korábban meghatározható volt a Jobbik támogatottságának egy jelentős földrajzi kerete, ez 2018-ra feloldódott. A kormányzópárt korábban jellemzően Jobbik bázisát jelentő területeken (Borsod-Abaúj Zemplén megye, Heves megye) is tudott erősíteni, így kiegyenlítve a támogatottságában korábban jellemző nagyobb regionális különbségeket.

A 2018-as választások földrajzi tapasztalatait összegezve megállapítható, hogy a korábban megfigyelt markánsabb választási földrajzi különbségek oldódtak. Lényegében az urbánus és rurális ellentét erősödött fel, a Fidesz-KDNP támogatottsága vidéken szinte teljesen kiegyenlítődött. A Jobbik támogatottságának koncentrációja az utóbbi 8 évben folyamatosan oldódott, így nincs már meg az a jelentős regionális beágyazottság, mint ami 2010-ben jellemezte a pártot. Azonban másik szempontból a taktikai szavazás és a voksok földrajzi eloszlásának jelentőségét mutatja, hogy a Fidesz-KDNP magasabb országos támogatottsággal kevesebb egyéni választókerületet tudott nyerni, mint 2014-ben.

Magyarországot a 2014-es és 2018-as országgyülési választások eredményeinek tekintetében egyszerre jellemezhetjük egyfajta állandósággal, hiszen a Fidesz-KDNP politikai dominanciája jellemezte az évtizedet és a földrajzi különbségek szerepe leértékelődött. Azonban, ha térben részletesen elemezzük a különbségeket, akkor dinamikus átrendeződéseket tapasztalhattunk, főként az ellenzéki táborok között, de a kormányzópárt szavazóinak területi koncentrációjában is. Ehhez szorosan hozzátartozik a gazdasági és társadalmi folyamatok által kialakított törésvonalak erősödése, ami részben meghatározta a pártidentitást. A változó politikai beágyazottságokból csak részben lehet következtetni a földrajzi torzulás folyamatára, így a mélyebb kapcsolatok feltárásához további matematikai statisztikai összefüggések vihetnek közelebb.

Összegezve az elmúlt öt országgyülési voksolás eredményeinek választási földrajzát felfedezhető egyfajta stabilitás és dinamizmus is. Az 1990-es évek politikai átrendeződését követően 2002-ben már kétpólusú volt a pártrendszer, aminek egyik oldalán az MSZP és SZDSZ, míg a másik oldalon a Fidesz-MDF és a végül sikertelen MIÉP volt található. Mindkét oldalnak jellegzetes területi sajátosságai voltak, ami 2006-ra némi változással stabilizálódott. Az egyik oldalon az MSZP és SZDSZ koalíciója megmaradt, míg a jobboldalon az MDF igyekezte megtörni a dualitást és külön úton indult el, míg a Fidesz új szövetségest talált magának a KDNP személyében. A 2000-es évek dualitását a 2010-es országgyülési választás véglegesen átírta. Az MSZP meggyengült, az SZDSZ és MDF kiesett a parlamentből. Továbbá megjelent a Jobbik és az LMP. Pártrendszer szempontjából a 2010-es évek a Fidesz-KDNP dominanciáját hozta, hiszen a centrális erötér müködött, miszerint egy erős nagypárt mellett sok közepes- és kispárt alkotja a palettát. Ez sokáig müködőképes volt, hiszen 2010-ben és 2014-ben az MSZP és szövetségesei második helyen csak középpártként szerepeltek, míg 2018ban már a Jobbik töltötte be ezt a szerepet. Az új választási rendszer stabilizálta a kormánypártoknak ezt a domináns helyzetét. 
Azonban a választási rendszer változtatására idővel a pártrendszer is válaszol, így ez előrevetíti a politika kétpólusú vetélkedést, ami az új szerveződések ellen hatnak, ami az elit által kontrolált politikai rekrutációt fogja eredményezni. A kormánypártok retorikai és szakpolitikai irányait, a jelenlegi politikai trendeket és az ellenzéki pártok kooperálását figyelve a 2020-as évekre ismét kétpólusú lehet a hazai pártrendszer, amit a jelenlegi kormányzó szövetség és ennek ellenzéke fog alkotni. Emellett a nemzetközi gyakorlathoz hasonlatosan (CHEN, J. - RoDDEN, J. 2013) hazánkban is felerösödni látszik a város és vidék közötti ellentét. 


\section{Földrajzi torzulások a magyar országyülési választási rendszerben}

Az egyenlőtlen politikai reprezentációt okozó választási rendszerek csak ritkán, míg a társadalmi folyamatok sokkal dinamikusabban változnak. A magyar választási rendszer általános aránytalanságai alapvetően a mandátumok kiosztásának módszeréből, a győzteskompenzáció mértékéből, a bejutási küszöbböl, a pártstruktúrából, a választói magatartásból erednek. Viszont szükséges kiemelni ezen ismérvek mellett, hogy a föbb rendszertulajdonságok mellett a térbeliségnek szintén kiemelt szerepe van. Mivel a földrajzi torzulások jelentősen hatnak az egyenlőtlen politikai reprezentációra, így a következő fejezetekben ezen tényezők mandátumkiosztást meghatározó szerepét elemzem.

A doktori értekezés több földrajzi léptéken igyekszik kimutatni a magyar választási rendszer összetett földrajzi torzulásait. Ebből adódóan az földrajzi torzulások fejezetben elsőként összevetem a magyar választási rendszerben megtalálható területi aránytalanságot és az erre ható demográfiai folyamatokat. Ezután a választáson megjelenő állampolgárok területi eloszlásának és a parlamentbe bejutott pártokra leadott voksoknak az aránytalanságot súlyozó tényezőjét mutatom ki a 2002 és 2018 közötti országgyülési választásokon. Végezetül a magyar választási rendszerben megtalálható gerrymanderinget vizsgálom az elmúlt öt parlamenti választás alapján.

\subsection{Malapportionment a magyar országgyülési választási rendszerben}

A hajdani jogalkotók törekvése szerint 1990-ben az egyéni választókerületeket úgy osztották fel, hogy a választópolgárok száma megközelítőleg azonos volt (1989. évi XXXIV.tv., 2/1990. I.11. Minisztertanácsi Rendelet). Továbbá a megyehatárok megkötésével számolva kinyilvánítottak, hogy körülbelül 60 ezer választópolgár alkosson egy területi egységet. Megállapítható, hogy már akkor jelentkeztek problémás választókerületek és sok esetben a megkötéseket sem sikerült tartani, így területi eltérések jelentkeztek. Ekkor azonban még nem beszélhettünk tudatos manipulációról, hiszen az 1990-es évek szabad választásait megelőzően gyakorlatilag fél évszázadig az állampolgároknak nem volt demokratikus joguk arra, hogy állást foglaljanak az ország jövőjéről. Tehát 1990-től egy újfajta politikai szocializáció is kezdetét vette.

Mindemellett az is fontos, hogy a globalizáció folyamata időközben jelentősen átformálta a társadalom és a gazdaság müködését. Napjainkra a nemzetgazdasági szint szerepe csökkent és előtérbe kerültek a lokális érdekek, föként nagyvárosok és vonzáskörzeteik szintjén. A rendszerváltozás hajnalán nehezen lehetett felvázolni, hogy milyen demográfiai és gazdasági folyamatok fogják jellemezni Magyarországot. Az azóta eltelt évtizedekben azonban a lakosság száma sok helyen módosult, felgyorsult a belső és külső migráció és időszerüvé vált a határok átrajzolása. Megállapítható, hogy a felnőtt lakosságszám változásának területi autokorrelációja arra a folyamatra is rávilágít, ami miatt a választókerületek korábbi behatárolása 2010-re tarthatatlanná vált (10. ábra). 


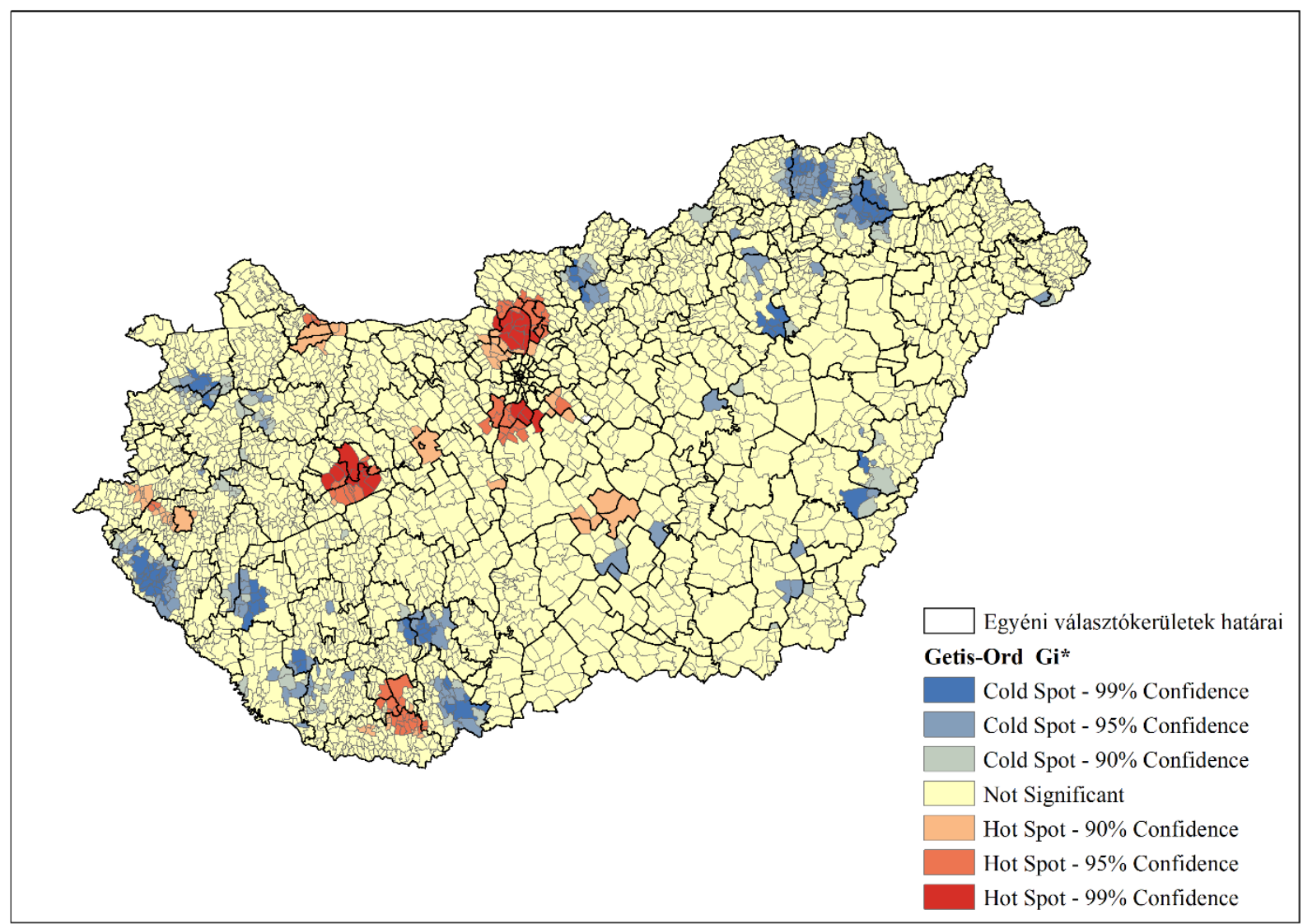

Forrás: Országos Területfejlesztési és Területrendezési Információs Rendszer alapján saját számítás és szerkesztés

A térkép alapján is megállapítható, hogy a kilencvenes évek elejétől jelentős demográfiai és migrációs folyamatok formálták a magyar társadalmat. Fontos megállapítani, hogyha a dinamikus folyamatot szeretnénk ábrázolni és elemezni (pl. 2001 és 2011 közötti felnőtt népesség számának változása településeként), akkor a módszer elfedheti a kis lakosságszámú települések extrém értékei mellett meghúzódó nagyobb volumenü, de fajlagosan nem nagy változásokat. Ilyen például Budapest vagy a vidéki nagyvárosok esete, ahol az abszolút csökkenés ellenére lehet fajlagosan forró pont és fordítva. Így az adatok értelmezésénél szükséges a fajlagos változás mellett azok abszolút értékének dinamikáját is figyelni, hiszen nem mindegy, hogy a választókerületek átszabásának elemzésénél Budapest szuburbanizációs folyamatait, vagy egy aprófalu demográfiai hanyatlását vesszük egy kalap alá.

A területi autokorreláció azt mutatja, hogy a szuburbanizáció megerösödésével a nagyvárosok (kiváltképpen Budapest) népességük egy részét elveszítették, miközben az elővárosi övezetek látványos népességgyarapodáson mentek keresztül (BELUSZKY P. 1999, ENYEDI GY. 2012, KovÁCS Z. 2007). A fóvároson kívül a vidéki regionális centrumokban (Győr, Debrecen, Pécs, Székesfehérvár) is jelentkezett ez a folyamat (BAJMÓcY P.1999, 2000, 2003, 2006), azonban a vidékről ezekbe a központokba történő áramlás választókerületi szinten inkább a lakónépesség és ezen belül a felnőttek helyi koncentrációját jelentette.

Az ország térszerkezetében bekövetkező radikális piacgazdasági változások, a centrumperiféria relációk átalakulása ugyancsak vándorlást idézett elő a gazdaságilag leszakadó, periférikus térségekből (volt ipari tengely egyes körzetei, Kelet-Magyarország), a dinamikus 
gazdasági fejlödésen keresztül ment térségekbe (pl. Nyugat-Magyarország, Balaton- térsége, a tágabb értelemben vett budapesti agglomeráció) (VIDA, GY. - DUDÁS, G. 2017). Mindezek következtében egyre nagyobb különbségek alakultak ki az egyes választókerületek méretében, amit a szélsőértékek is jól mutatnak (11. ábra).

\section{1. ábra A választásra jogosultak szélsőértékei az egyéni választókerületekben 1990-2018 között}

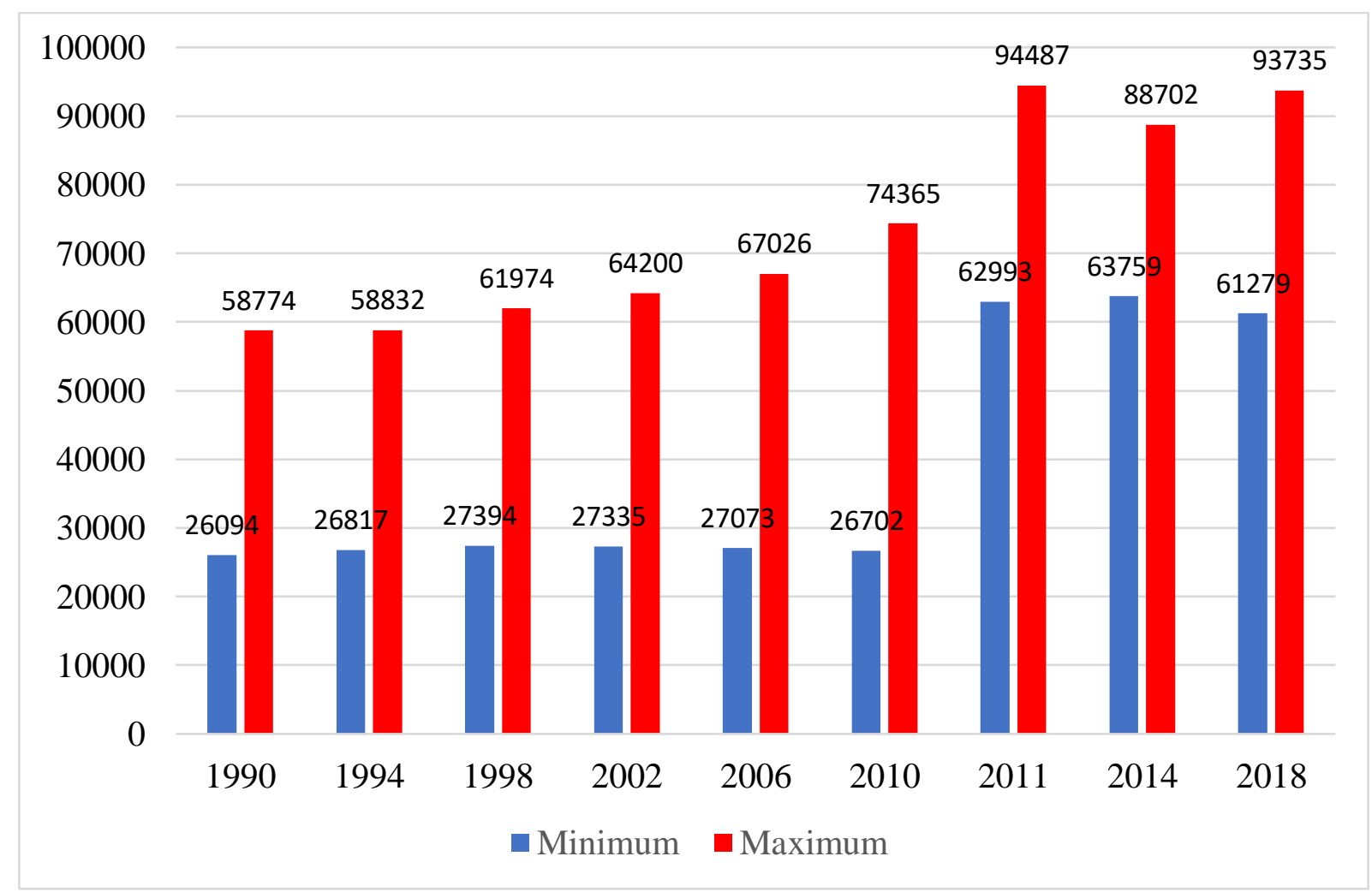

Forrás: Központi Statisztikai Hivatal és a Nemzeti Választási Iroda adatai alapján saját szerkesztés

Megállapítható, hogy az 1990-es évek végéig nem nőtt annyira jelentős mértékben a különbség, hiszen 1990-ben a legnagyobb és legkisebb választókerület hányadosa 2,25 volt, 1994-ben 2,19, míg 1998-ban 2,26 volt ez az érték. Azonban föként az ezredfordulót követően már látszott a maximum érték dinamikus növekedése, mivel 2002-ben a hányados értéke 2,35, 2006-ban 2,48 és 2010-ben már 2,78 volt. Ez a divergencia egyre jobban sértette az egyenlő szavazat elvét. 2011 után az új beosztásban csökkent a kilengés hovatovább 2014-re tovább is záródott az olló, azonban 2018-ra újra elindult a divergencia a legnagyobb és a legkisebb választókerület között.

1990 és 2010 között a fővárosi agglomerációban és a többi nagyvárosi térség választókerületeiben a szuburbanizáció és a belső migráció folyamata emelte jelentősen a választásra jogosultak számát. Választási földrajzi szempontból a jelenséget árnyalja, hogy a vidéki nagyvárosok szuburbanizációja kevésbé csökkentette a nagyvárosi kerületek választásra jogosultjainak számát, hiszen több esetben a belváros mellett több környékbeli község is egy egységbe tartozott (1.melléklet). Ilyen volt például a szegedi 2-es tortacikk formájú választókerület. Ezzel ellentétben a vidéki választókerületekben a természetes fogyás és az elvándorlás következtében egyre kevesebb választópolgár élt (2. melléklet).

A területi különbségek eszkalálódásában tehát a lehatárolás mellett a népesség földrajzi elhelyezkedésének és demográfiai viszonyainak is kulcsszerep jutott (HAUG, S. 2008, HÁRS Á. 
2010, KSH 2018). Meglátásom szerint a demográfiai változások, hosszabb távon a fertilitás és mortalitás különbségei, míg rövidebb időtávon az országon belüli migráció jelentős mértékben hat a területi aránytalanság mértékére is.

Megállapítható az is, hogy a magyar gazdasági versenyképesség és a területi különbségek növekedése közvetett módon befolyásolta a választókerületek népességszámának alakulását, hiszen folyamatos és egyenlőtlen belső migrációt generált a fejletlenebb és a fejlettebb térségek között, a munkaerö a magasabb jövedelmü térségekbe költözött (KSH 2018). Általában a fiatalabb, iskolázottabb rétegek költöztek el, amivel megemelték a választópolgárok számát az adott területen, míg a fejletlenebb térségekben elöregedő és egyre kevesebb szavazó maradt.

Az előző folyamatok felerősödése miatt idővel a lakóhely egyre nagyobb mértékben meghatározta a szavazat értékét. Ebből adódóan egyre komolyabb kihívást jelentettek a túl nagy, vagy túl kicsi országos egyéni választókerületek, aminek térbeliségét a 2010-ben a választásra jogosultak átlagához viszonyított arány is jól kifejezett (12. ábra).

\section{2. ábra A választásra jogosultak százalékos aránya az országos átlaghoz viszonyítva a 176 egyéni választókerületben 2010-ben}

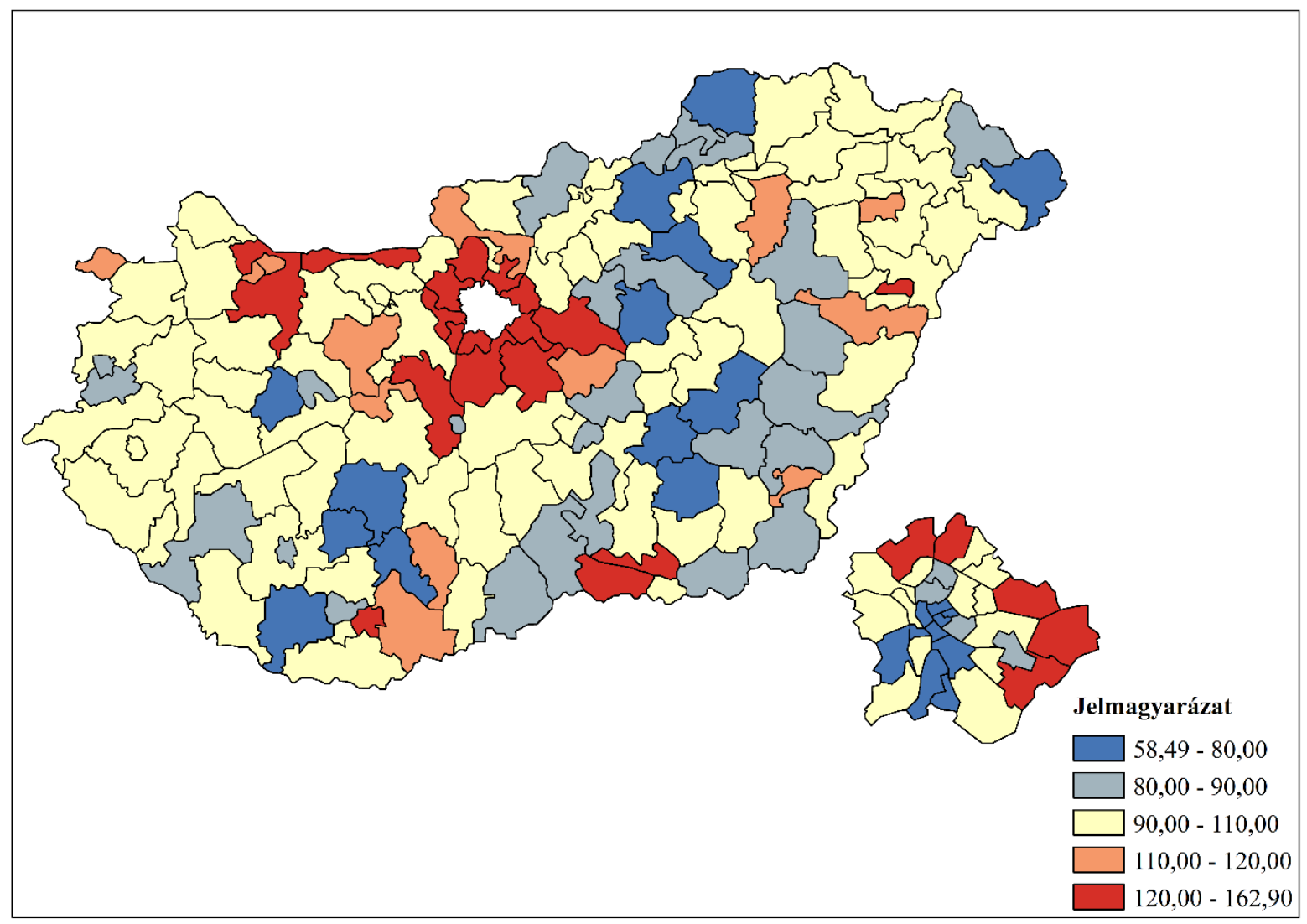

Forrás: Nemzeti Választási Iroda adatai alapján saját számítás és szerkesztés

Budapestet leszámítva, az urbánusabb térségekben általában kevesebbet ért egy szavazat, mint vidéken. Az időközben végbement demográfiai folyamatok jóvoltából 2010-ben a legkisebb választókerületben az egy mandátumhoz szükséges voks értéke 2,79-al volt nagyobb, mint a legnagyobban. Ez a különbség 1990-ben még 2,25 volt, ami már akkor is jelentős eltérésnek minősült, de 2010-ben már voltak olyan megyék, ahol a kerületek között több mint kétszeres eltérés volt kimutatható a húsz évvel korábbihoz képest. 
Az új választókerületi beosztás nyomán egyértelmüen csökkentek a méretbeli eltérések, a legnagyobb választókerület másfélszer volt nagyobb a legkisebbhez képest, a korábbi 2,79-es értékkel szemben. Ez a 2014-es választásokra mérséklődött, hiszen ekkor a maximum és minimum hányadosa 1,39 volt, majd 2018-ban ismét növekedni kezdett és átlépte a másfélszeres $(1,53)$ különbéget. Az országos átlagtól való eltérés is mérsékeltebb a kerületek többségénél, ami mutatja, hogy részben sikerült orvosolni a választók térbeli eloszlásának különbségeit (13. ábra, 3. melléklet).

Megállapítható az is, hogy a határmeghúzás kritériumai közül a nagyobb átlagos méretek miatt komoly problémát jelentett, hogy a megyék határát egy választókerület sem keresztezheti. A megyénként eltérő felnőtt lakosságszámhoz igazodó térfelosztás komoly földrajzi kihívást jelent, ami az amerikai szövetségi államhatárok korlátozó szerepéhez hasonlatos (WEBSTER, G.R. 2013a,b). Így a jövőben a rurális, periférikusabb helyzetű térségekben a túl kicsire szabott országgyülési egyéni választókerületek jelentik a problémát, míg a főváros és a vidéki nagyvárosok melletti szuburbán területeken föként a túlméretezés jelentett komolyabb kihívást.

13. ábra A választásra jogosultak százalékos aránya az országos átlaghoz viszonyítva a 106 egyéni választókerületben a 2011-es népszámlálási adatok alapján

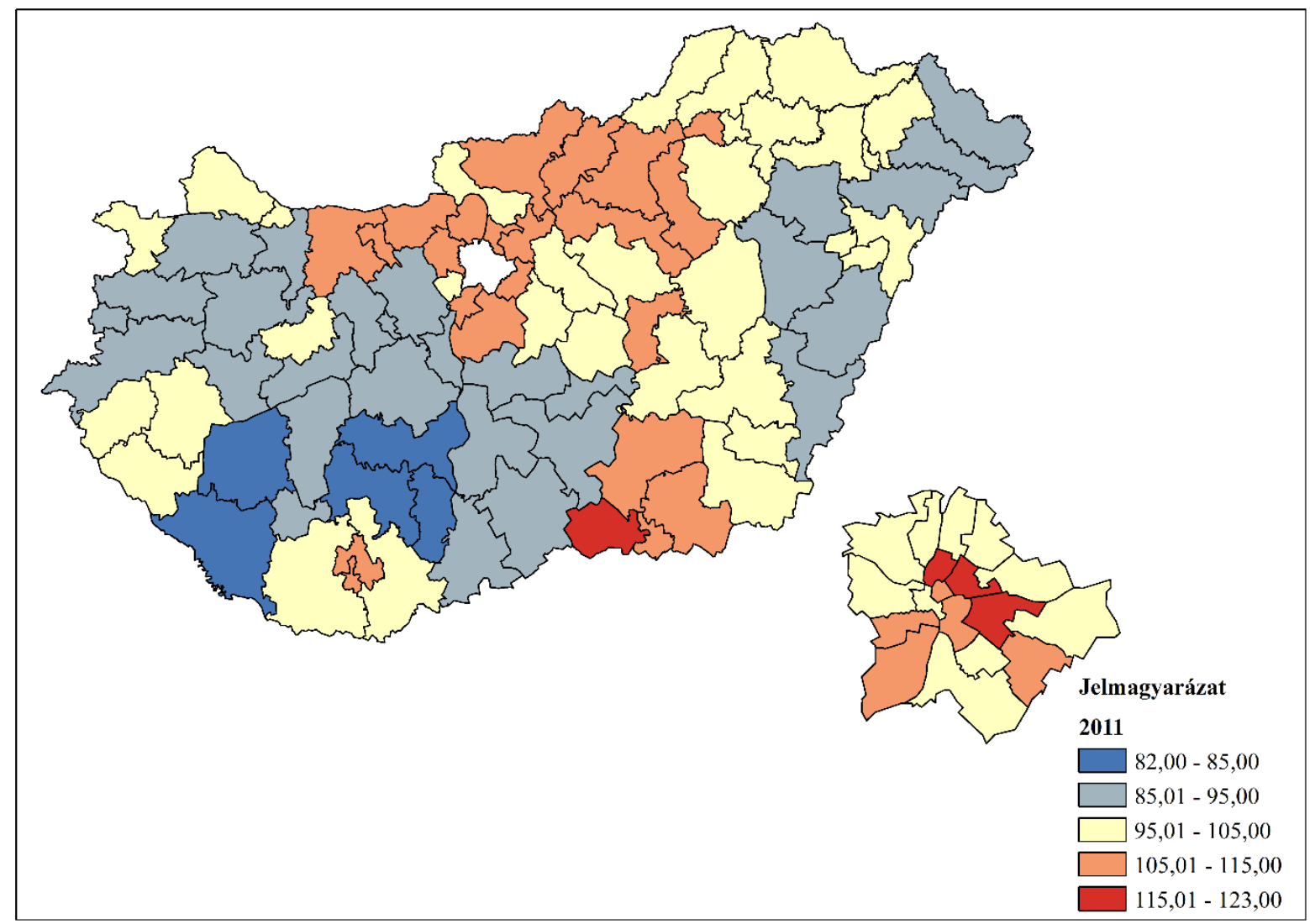

Forrás: Központi Statisztikai Hivatal adatai alapján saját számtás és szerkesztés

Az új jogszabály az országgyülési egyéni választókerületek méretbeli (választásra jogosultak száma) eltérésének még tolerálható szintjét az országos átlaghoz viszonyított $15 \%$ ban húzta meg. Ennél nagyobb eltérés esetén már módosítást javasol a megyehatárok megkötésével, valamint az egybefüggő választókerületek megkövetelésével. A törvény $20 \%$ feletti különbség esetén pedig egyenesen kötelezi az országgyülést a módosításra, ha több mint egy év van a következő országgyülési választásokig $[1,2]$. Ebből következik, hogy már 
a lehatárolás pillanatában sérült a jogszabályi korlát, hiszen Tolna és Somogy megyékben túl kicsik, míg Csongrád, Heves, Komárom-Esztergom és Nógrád megyékben túl nagyok lettek a létrehozott új választókerületek. Ha a múltbéli demográfiai trendeket nézzük ezek közül sok esetben indokolt módosítás történt (pl. Győr-Moson-Sopron, Heves, Fejér megye), de a legnagyobb problémát az új beosztásban Csongrád és Pest megye túl nagy, valamint Tolna és Somogy megye túl kicsi választókerületekre szabása okozta.

Ezt támasztja alá a 2011 óta végbement 18 évesnél idősebb lakosságszám változásának területi autokorrelációja, ami a lakóhelyi mobilitás felgyorsulását és a választási földrajzi kihívás gyors újra-termelődését mutatta (

14. ábra). Budapest körül a város határához közeli övezetben az új lakásépítkezések nyomán (pl. lakóparkok) jelentősen nőtt a népesség (HEGEDÜs G. 2009, 2012). Emellett a fóváros körüli tágabb régióban a korábbi húsz évhez képest jelentősen nőtt a népesség, ami a budapesti várostérség országon belüli gazdasági erejét és a szuburbanizáció térbeli kiteljesedését jelzi.

14. ábra: A felnőtt lakosságszám 2012 és 2018 közötti változásának települési szintü Getis-Ord féle lokális területi autokorrelációja

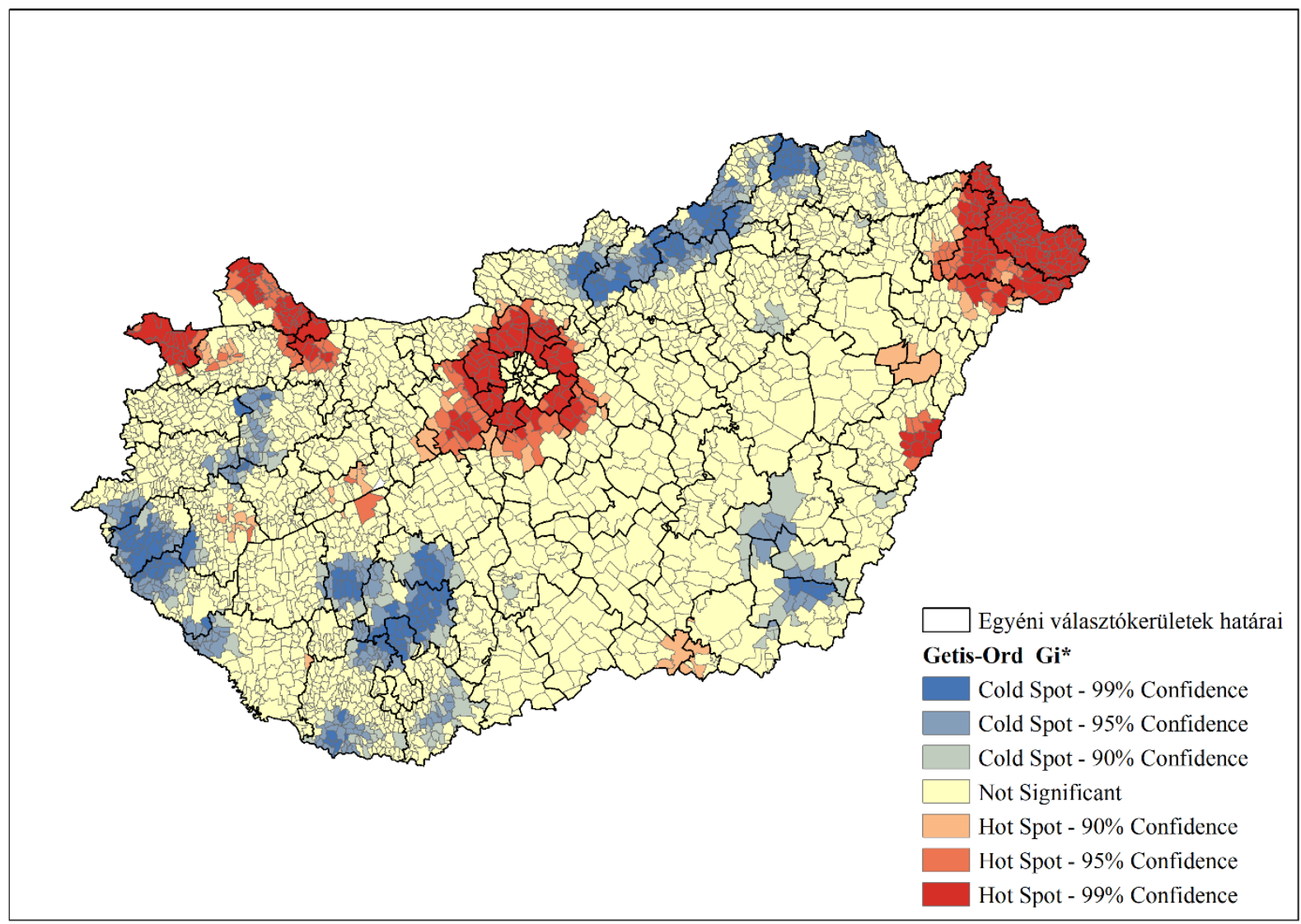

Forrás: Országos Területfejlesztési és Területrendezési Információs Rendszer alapján saját számítás és szerkesztés

A vidéki regionális centrumok közül Pécs korábbi helyzete visszaesett míg Győr és Székesfehérvár maradt dinamikus (10. ábra), valamint az utóbbi időben Szeged térsége javult. Mindemellett Győr-Moson-Sopron és Vas megyében, valamint Szabolcs-Szatmár-Bereg megye határ menti területein is dinamikus növekedés tapasztalható 2012 és 2017 között. Míg 
az első két példa változásában az országon belüli kelet-nyugati irányú belső migráció a felelös, addig az utóbbit főként a Kárpátaljáról történő tömeges bevándorlás okozta. Ebből adódik, hogy az elözetes várakozásoknak megfelelően a 2018-as országgyülési választásokra már több, mint tíz választókerület átlépte a 15\%-os beavatkozási határt, hol az átlagtól való pozitív, hol a negatív eltérés miatt (15. ábra).

Szembetünő folyamat 2011-hez képest, hogy Budapest belvárosi választókerületeiben jelentősen csökkent a felnőtt lakónépesség száma, ami az elöregedés, továbbá a magas telekárak miatti funkcionális átalakulás következménye. A fỏváros agglomerációjában tovább folytatódott a választópolgárok számának és relatív arányának dinamikus növekedése, így a $15 \%$-os küszöböt több választókerület is meghaladta, sőt kettő át is lépte a jogszabályban meghatározott 20\%-os határt.

15. ábra: A választásra jogosultak százalékos aránya az országos átlaghoz viszonyítva a 106 egyéni választókerületben a 2018-as országgyülési választások alapján

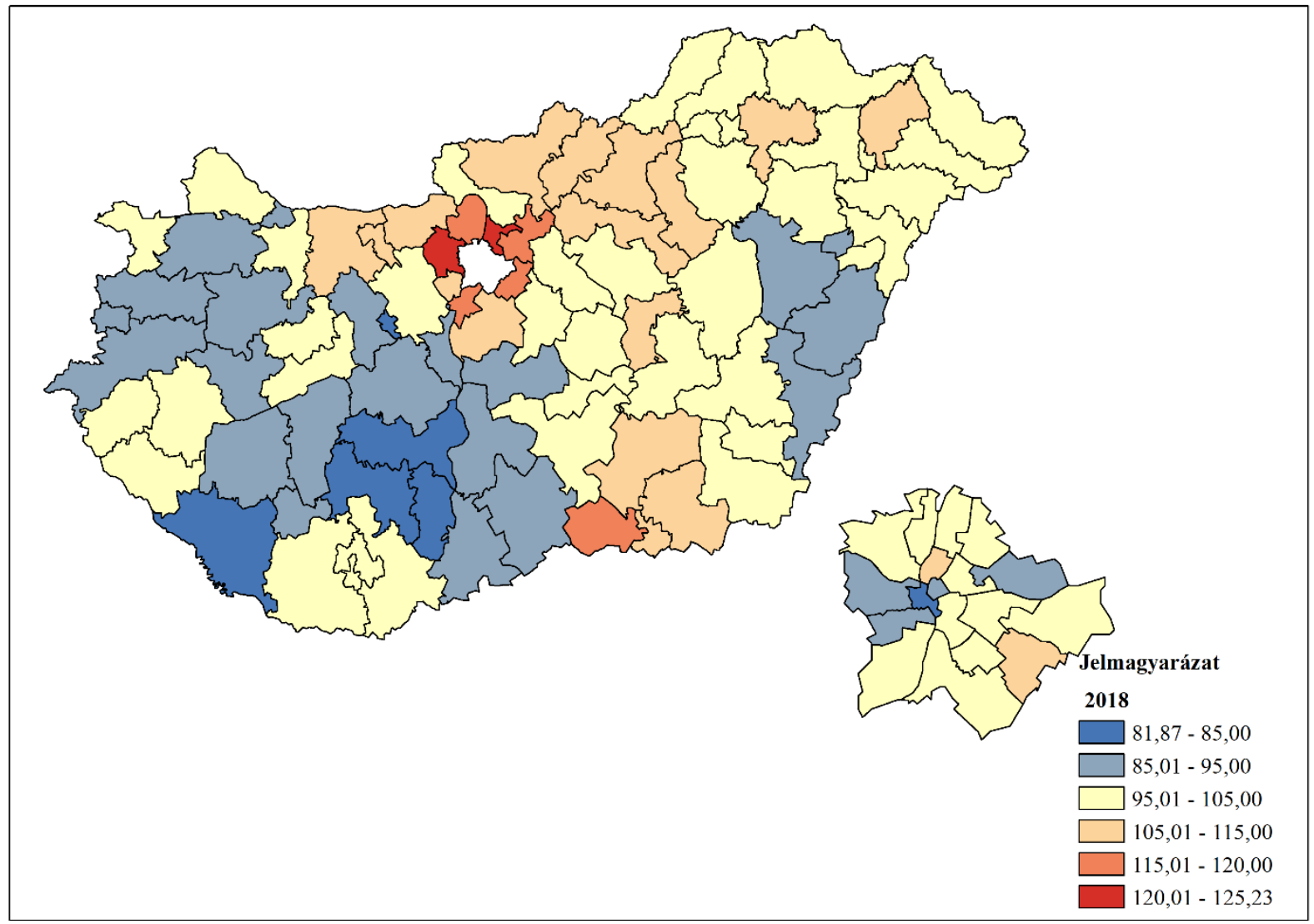

Forrás: Nemzeti Választási Iroda adatai alapján saját számítás és szerkesztés

A közelmúlt demográfiai tendenciáit figyelembe véve ez a helyzet a jövőben tovább fog súlyosbodni, hiszen a föváros környéki területen a lakónépesség további növekedése várható, ami azt vetíti elöre, hogy a közeljövőben újabb módosításra szorul a beosztás. Ha a jelenlegi demográfiai folyamatokat tovább vetítjük, akkor egyre több választókerület fogja sérteni a törvényben rögzített kereteket, ami már így is jogszabályellenes és kötelezné a törvényalkotást a határok átalakítására. Emellett a jövőben (az aktuális népszámlálásokat követően) is indokoltnak látszik időről-időre felülvizsgálni a szavazásra jogosultak térbeli eloszlását, hiszen a kezdeti status-quo-t a demográfiai és migrációs folyamatok idővel felülírják. Az eredményekből az is kirajzolódik, hogy a választókerületek száma és a megyék közötti 
elosztása is jelentős átalakításra szorul. Ehhez egy a földrajzi tényezőket jobban mérlegelö térfelosztást kellene alkalmazni.

Azért is fontos a szakértői térfelosztás, mert a kezdeti peremfeltételeket a választási részvétel markáns egyenlőtlenségei és a mandátumkiosztásba be nem kerülő voksok földrajzi eltérései jelentősen módosítják. Így nem a kezdeti feltételek fogják a gyakorlatban meghatározni az egyenlőtlenségeket, hanem a választás napján létrejött vokshalmazok közötti földrajzi eltérések. Ebből adódóan szükséges elemezni a területi aránytalanságokat módosító tényezőket is.

\subsection{Reactive malapportionment a magyar országyülési választási rendszerben}

Az előző kutatási eredményekből következtethetünk, hogy a választásra jogosultak számának földrajzi eloszlása és kerületekbe sorolása meghatározza az egy mandátumra jutó vokshalmaz lehetséges méretét. Azonban a megvalósult földrajzi torzulásában a választási részvétel és az érvényes parlamenti mandátumszámításba került voksok területi egyenlőtlenségei játszanak közre. Mivel a választási részvétel jelentősen módosítja a mandátumkiosztás területi egyenlőtlenségeit ezért ennek vizsgálata fontos. Megállapítható, hogy a választási részvétel földrajzi sajátosságaira egyaránt jellemző egyfajta stabilitás és dinamizmus is.

A két beosztás által kialakított rendszerben választókerületi szinten a fơváros és agglomerációja mellett Heves megye, a Nyugat-Dunántúl régió és néhány megyei jogú város kompakt kerületében magas a részvétel, míg az ország külső és belső perifériáinak jelentős részén alacsony. Ebből kifolyólag statisztikai szempontból is kimutatható egyfajta ok-okozati kapcsolat a strukturális változók és a választási részvétel között. A számításokból kirajzolódik, hogy a jelenlegi választókerületi beosztás szintjén a társadalmi és gazdasági helyzet eltérései 2014-ben és 2018-ban is több mint 70\%-os értékkel, lineárisan magyarázták a választási részvétel varianciáját. Tehát a sikeresebb helyzetü kerületekben magasabb a választói aktivitás, és ez a lineáris összefüggés egyértelmüen kimutatható.

A választókerületi adatokhoz képest a 2002-es, 2006-os, 2010-es, 2014-es és 2018-as parlamenti választások leíró települési szintủ részvételi eredményei alapján (4. melléklet5. melléklet6. melléklet7. melléklet8. melléklet) Magyarországon meghatározhatjuk azokat a földrajzi helyeket, ahol magas és ahol alacsony az aktivitás. Azonban a témakörhöz kapcsolódva a választókerületek meghatározásához szükséges területi statisztikával kimutatni a markánsan aktív és inaktív területeket. Ebből adódóan először bemutatom a legutóbbi öt parlamenti választás átlagos részvételi arányának területi autokorrelációját lokális $\mathrm{G}^{*} \mathrm{i}$ statisztikával települési szinten, ahol a szavazók aktív módosító hatása megragadható (16. ábra). Majd a mandátumkiosztásban hasznosult listás voksokkal tovább súlyozva fejezem ki a megvalósult földrajzi torzulásból a területi aránytalanságra ható módosító tényezőket.

A 2002 és 2018 közötti országgyülési választások átlagos részvételének területi autokorrelációja is alátámasztja, hogy hosszabb távon az ország mely részein magas a választási aktivitás és hol szavaznak általában kevesebben. Néhány kivételtől eltekintve hazánkban a választási aktivitás idősoros átlagértékeiből megrajzolhatunk egy Sátoraljaújhely és Lenti között húzódó tengelyt. Ettől északra átlagosan magasabb a választási aktivitás, míg délre általában alacsony részvétel tapasztalható. 
Fontos térbeli sajátosság, hogy a területi autokorrelációs térkép részben megerősíti a részvételi adatok leíró mintázatát (9. melléklet, 10. melléklet, 11. melléklet, 12. melléklet, 13. melléklet), azonban néhol felfed további lokális sajátosságokat. Emellett felfedezhető a területi lehatárolás eredményekre gyakorolt hatása itt is, hiszen találhatunk olyan választókerületeket (pl. Borsod-Abaúj-Zemplén megye 3-as OEVK), ahol a kerületeken belül extrém magas és alacsony aktivitású települések is megtalálhatók. Az is kimutatható, hogy ezen a szinten kevésbé válik el a nagyobb városok és vidéki területek között a választási részvételben megmutatkozó markáns különbség.

\section{6. ábra: A 2002-és 2018 közötti országgyủlési választások átlagos részvételének települési szintü Getis-} Ord féle lokális területi autokorrelációja

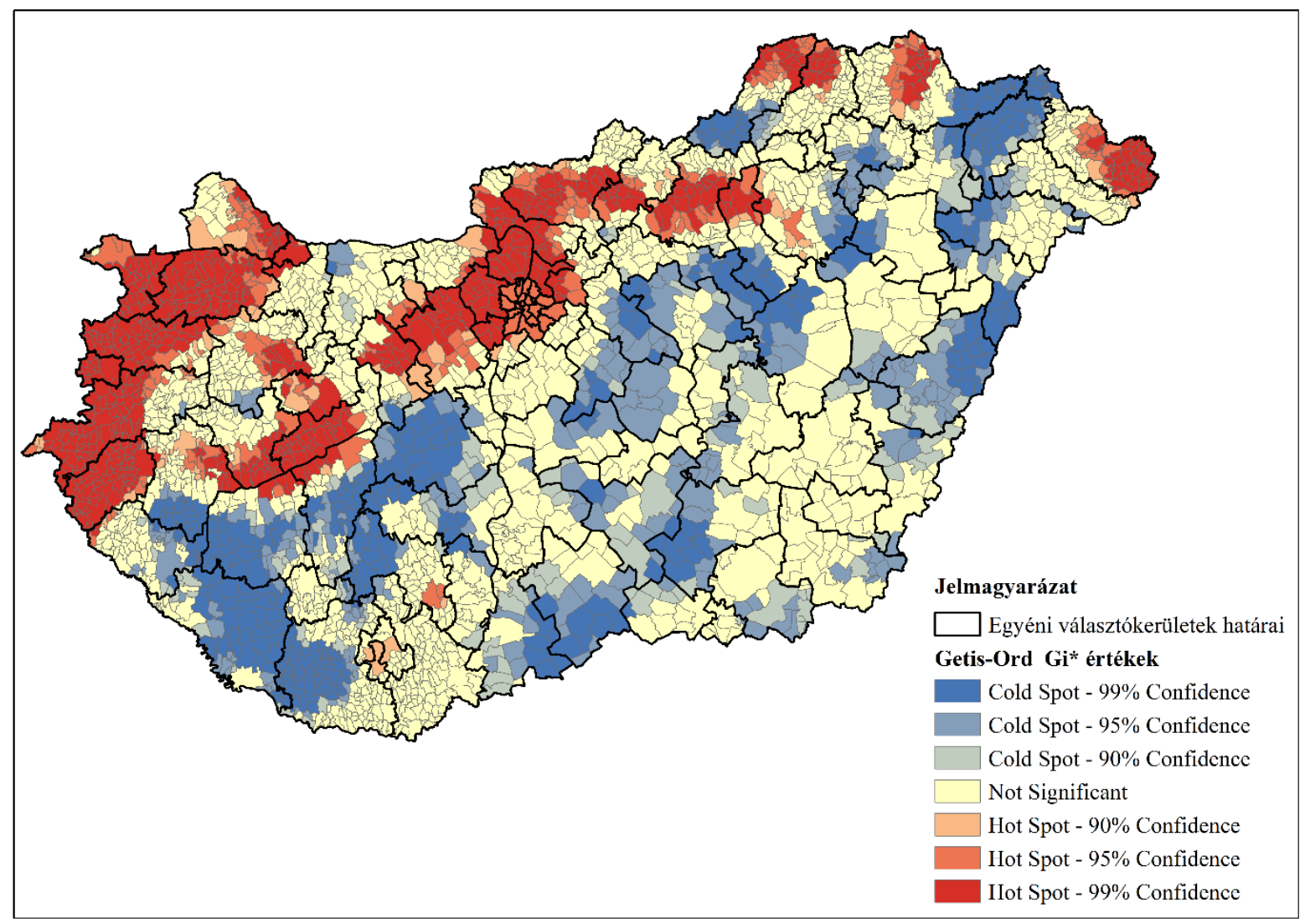

Forrás: Nemzeti Választási Iroda adatai alapján saját számítás és szerkesztés

Az iménti jelenség oka a szakirodalmak által már korábban is igazolt részvételi sajátosság, miszerint a legmagasabb értékeket az apró és törpefalvaknál, valamint a nagyobb városoknál tapasztalunk. Mivel megnőtt az elemszám (több mint 3000) ezért a kerületi szinthez képest jobban kirajzolódnak a kis lakosságszámú települések extrémebb értékei és a nagyobb volumenü, de fajlagosan nem kiugró értékek eltörpülnek. Ez azt támasztja alá, hogy az adatok értelmezésénél mindig a fajlagos változás mellett azok abszolút dinamikáját is érdemes figyelembe venni. Mindemellett a területi autokorreláció jól tájékoztat a választási részvétel, hovatovább a pártok szavazóbázisának térbeli mintázatairól, de módszertani korlátok is adódhatnak, amit az értelmezésnél szükséges figyelembe venni. Meg kell jegyezni, hogy föként csak statikus, egy időre vonatkozó fajlagos értékekkel mutatja ki jól a földrajzi mintázatot, viszont érzékeny a lehatárolt objektumok alakjára és méretére, valamint a szomszédos poligonok tulajdonságaira, amit figyelembe kell benni (TóTH G. 2003). 
A szavazói magatartás időbeli stabilitását az is alátámasztja, hogy a földrajzilag súlyozott regressziós számítások szerint települési szinten a 2010-es választási részvétel több mint 50 százalékban magyarázta a 2018-as érték varianciáját (14. melléklet). Választókerületi szinten ezek az összefüggések magasabb értéküek 2002 és 2010, valamint 2014 és 2018 viszonylatában. Ugyanezt 2002 és 2018 között az eltérö földrajzi lehatárolás miatt nem lehet lineárisan modellezni. Mivel a választási aktivitás területi különbségei lassan változnak, ezért a választókerületek esetleges áttervezésénél ezt is figyelembe kell venni.

Mindemellett kivehető települési szinten is a gazdaságilag fejlettebb területek magas, míg a periférikus területek alacsony aktivitása. Ezért a választási aktivitás földrajzi leírása mellett szükséges a kapcsolatokat statisztikai módszerekkel is elemezni. Az adatok elérhetősége miatt 2010 és 2018 között lehetett összefüggéseket kimutatni, de települési léptéken így is meghatározhatók szignifikáns korrelációk és regressziók a választási részvétel és a regionális versenyképesség komponense (egy lakosra jutó jövedelem, munkanélküliségi ráta, 100 lakosra jutó adózók) között. Azonban a vizsgált településeket lélekszám szerint differenciálva különböző erősségü statisztikai összefüggéseket lehetett felfedezni (17. ábra).

17. ábra A regionális versenyképesség főkomponens és a választási részvétel Pearson korrelációi 2010 és 2018 között

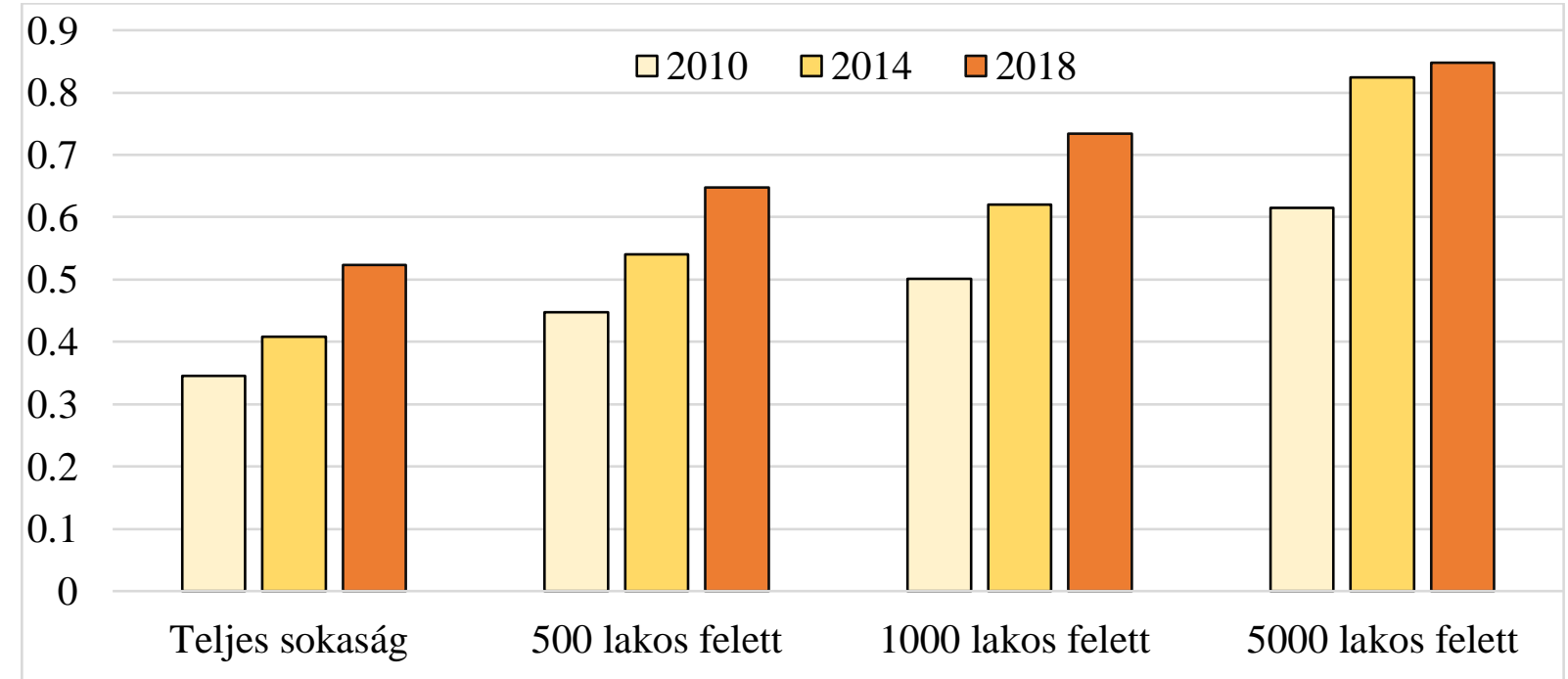

Forrás: A Központi Statisztikai Hivatal és a Nemzeti Választási iroda adatai alapján saját szerkesztés

A teljes sokaságot figyelembe véve 2010-ben pozitív irányultságú gyenge, majd 2014-re és 2018-ra közepes korreláció figyelhető meg. A növekvő tendencia arra enged következtetni, hogy 2010 és 2018 között a részvétel területi összefüggése a jövedelmi és társadalmi helyzettel erősödött. Fontos azt is kiemelni, hogy településméret szintjén differenciálva nagyobb Pearson korrelációk és erősebb ok-okozati kapcsolatok tapasztalhatók. Ha az 500, az 1000, végül az 5000 lakos feletti településeket külön vizsgáljuk, akkor a regionális versenyképesség főkomponense egyre nagyobb százalékban magyarázza a választási részvételt. Ha az 5000 feletti településeket elemezzük és a korrelációkat négyzetre emeljük, az egyváltozós lineáris regresszió 2014-re és 2018-ra közel 55 százalékos magyarázóerőt vesz fel.

Elméleti szempontból az ok-okozati viszonyok elemzésénél célszerü a linearitást is megkérdőjelezni, hiszen többször a választói magatartásra a társadalmi tényezők nem egyenesen arányosan hatnak. Ezért a főkomponenst felhasználva meghatározható logaritmikus regressziós kapcsolat a részvétel földrajzi különbségeivel. Hovatovább az is kimutatható, hogy 
az 5000 fö feletti településeknél a logaritmikus összefüggés pár százalékponttal magasabb magyarázóerővel rendelkezik a lineárisnál, tehát a nagyobb lélekszámú településeknél egy bizonyos jövedelmi és társadalmi helyzet felett már nem egyenesen arányos módon növekszik a térségek választási aktivitása. Összegezhető, hogy a választókerületi szinthez képest települési léptéken csökken a társadalmi és gazdasági mutatók magyarázó ereje, azonban még így is jelentős marad. Az ok-okozati kapcsolatok irányultsága pozitív marad, aminek köszönhetően nem fedezhető fel a térbeli Simpson-paradoxon sem.

Az előzőekből következő gyakorlati javaslatom, hogy Magyarországon Budapesten és az agglomerációjában, az osztrák határ mentén, valamint Fejér, Heves, Nógrád és Veszprém megyékben célszerü a hagyományosnál is kisebb választókerületeket rajzolni. Ezzel ellentétben a Sátoraljaújhely-Lenti vonaltól délre néhány kivételtől eltekintve lehet több választásra jogosulttal rendelkező kerületet kialakítani. Mivel ez még nem következett be így ebből következik, hogyha összehasonlító elemzést végzünk választókerületi szinten, megállapítható az a jelenség, hogy 2002 és 2010 között a részvételi különbségek csak tovább növelték az amúgy is súlyos eltéréseket (15. melléklet, 16. melléklet, 17. melléklet). Ha a részvétellel súlyozott értékekkel vizsgáljuk a legkisebb és legnagyobb választókerületet, akkor számításaim szerint 2002-ben a különbség 2,58 szoros, 2006-ban 2,72 szeres, míg 2010-ben már több mint 3,08 szoros volt. Tehát 2010-ben a részvétellel súlyozott legnagyobb választókerület több mint háromszor nagyobb volt, mint a legkisebb, amivel a voksok értéke nagyon szóródott. Tehát szükségszerü volt egy új térfelosztás.

Az új választókerületi lehatárolás a korábban említett hiányosságaival csökkentette ugyan a jelentős eltéréseket, de a demográfiai trendek figyelmen kívül hagyása mellett a részvételi jellegzetességeket sem vette kellőképpen figyelembe. Így a főváros körül, valamint Heves és Nógrád megyében túl nagyra, míg a Dél-Dunántúlon túl kicsire szabta a kerületeket. Így a 2014 óta müködő térfelosztásra is jellemző, hogy a választásra jogosultak különbsége mellett az egyenlötlenséget tovább fokozta a részvételi aktivitásban megfigyelhető különbség (18. melléklet, 19. melléklet). A maximum és minimum hányadosa 2014-ben (1,77) és 2018-ban $(1,83)$ is érzékelhetően nagyobb egyenlőtlenségeket mutatott a választásra jogosultak eltéréseinél. Tehát az eredmények alátámasztják, hogy Magyarországon a választási aktivitás is módosító hatással bír, és a különbséget alakító két fô ok (a választópolgárok számának és a részvételi aránynak a különbsége) több helyen együtt jelentkezik. Ebből következik, hogy hagyományosan jelentős területi egyenlőtlenség figyelhető meg a magyar választási rendszerben. Ahhoz, hogy meghatározzuk ez kiknek kedvez, további vizsgálatokat kell végezni, hiszen addig nem beszélhetünk pártot vagy bármilyen csoportot helyzetbe hozó területi aránytalanságról és ennek súlyozott értékeiről, amíg ez nincs bizonyítva.

Ezért a témakör vizsgálatakor a választókerületekben a választásra jogosultak száma mellett a részvételt és a mandátumkiosztásban hasznosult voksokat is célszerü elemezni, térképre vinni. Ezt először a régi- (20. melléklet, 21. melléklet, 22. melléklet), majd az új beosztással (23. melléklet, 24. melléklet) végeztem el és ábrázoltam. Ezután érdemes az eredményeket összevetni a pártok listás szavazatarányaival (18. ábra, 12. táblázat). Megállapítható, hogy a pozitív Pearson korrelációs értékek azt mutatják, hogy az adott párt ott teljesít jobban, ahol alapvetően a választókerületben több szavazó van, míg a negatív érték ennek ellentétes irányultságát mutatja. Fontos megjegyezni, hogy a statisztikai összefüggések vizsgálataihoz kapcsolódóan szükséges volt a választókerületeket egy urbánus-rurális tengelyen matematikailag kifejezni, illetve rangsorolni. Ennek során a népesebb város nélküli „rurális kerületek” egyes értéket kaptak, ahol a központi település lélekszáma meghaladta az 50 ezer föt kettest, a vidéki nagyvárosok kerületei hármast, míg a fővárosi választókerületek négyest. Az így létrehozott rangsorolással mérhetővé vált a városias és vidékies választókerületekben koncentrálódó voksok összefüggései a Spearman rangkorreláció módszerével is. 
18. ábra: Pearson korrelációs összefüggések iránya a korábbi választókerületi rendszerben a pártok listás eredményei és a választásra jogosultak, választáson résztvevők, valamint a parlamentbe bejutott pártokra leadott listás voksok alapján

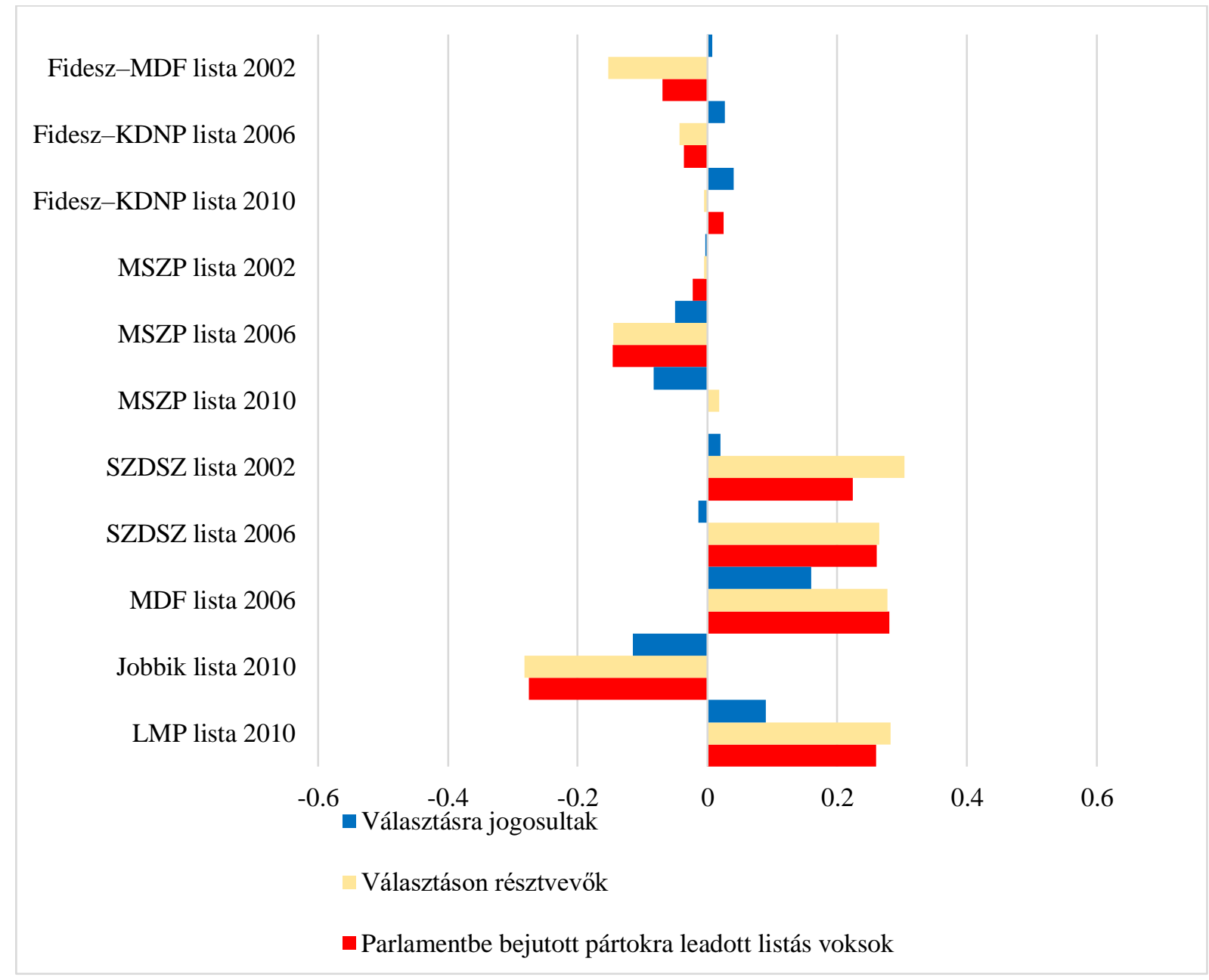

Forrás: Nemzeti Választási Iroda adatai alapján saját számítás és szerkesztés

A Pearson korrelációs értékekből megállapítható, hogy 2002 és 2010 között a korábbi rendszerben a választásra jogosultak választókerületi szintủ területi eloszlásának nem volt szignifikáns összefüggése egyik párt listájával sem. Tehát a kezdetleges igazságtalan keretfeltételek egyik pártot sem hozták igazán helyzetbe. Ha a részvétellel súlyozott értékeket vettettem össze a pártok támogatottságával, akkor már a kisebb pártok mutattak gyenge korrelációt. A gyenge pozitív irányultságot az SZDSZ, az MDF és az LMP pártok esetében volt tapasztalható, míg a Jobbik esetében negatív volt ez az összefüggés.

Ha tovább elemezzük az összefüggéseket és a megjelent választópolgárokból kivonjuk az érvénytelen és a mandátum számításba be nem kerülö voksokat, akkor a részvétellel súlyozott különbségek által kirajzolt trend érdemben nem változott. A két nagypárt esetében 2002 és 2010 között nem volt szignifikáns összefüggés, sem a Fideszt, sem az MSZP-t nem hozta helyzetbe a vizsgált tényező. A Jobbiknak 2010-ben még kedvezett is a részvétel és a hasznos listavoksok földrajzi eloszlása, míg az SZDSZ, MDF és LMP minden esetben hátrányba került. Ennek egyik fö oka a pártok támogatottságának térbelisége. 
12. táblázat: A 2002-es, 2006-os és 2010-es pártlistás eredmények, a területi aránytalanság és reactive malapportionment tényezői közötti Pearson, valamint Spearman (*-al jelölve a táblázatban) korrelációs értékek

\begin{tabular}{lcclcccccccc}
\hline \multirow{2}{*}{ Választókerületek } & Fidesz- & Fidesz- & Fidesz- & MSZP & MSZP & MSZP & SZDSZ & SZDSZ & MDF & Jobbik & LMP \\
& MDF & KDNP & KDNP & lista & lista & lista & lista & lista & lista & lista & lista \\
$2002,2006,2010$ & lista & lista & lista & 2002 & 2006 & 2010 & 2002 & 2006 & 2006 & 2010 & 2010 \\
& 2002 & 2006 & 2010 & & & & & & & &
\end{tabular}

\begin{tabular}{|c|c|c|c|c|c|c|c|c|c|c|c|}
\hline Urbánus-rurális* &,- 540 &,- 493 &,- 491 & ,234 &, 122 & ,655 & ,638 &, 735 & ,297 &,- 616 &, 762 \\
\hline $\begin{array}{l}\text { Választásra } \\
\text { jogosultak } \\
\text { számának aránya } \\
\text { az országos } \\
\text { átlaghoz } \\
\text { viszonyítva }\end{array}$ &, 007 &, 027 &, 040 &,- 003 &,- 050 &,- 083 & 020 &,- 014 &, 160 &,- 115 & ,090 \\
\hline $\begin{array}{l}\text { Választáson } \\
\text { résztvevők } \\
\text { számának aránya } \\
\text { az országos } \\
\text { átlaghoz } \\
\text { viszonyítva }\end{array}$ &,- 153 &,- 043 &,- 005 &,- 005 &,- 145 &, 018 & ,304 & ,265 & ,277 &,- 282 & ,282 \\
\hline $\begin{array}{l}\text { Parlamentbe } \\
\text { bejutott } \\
\text { pártokra } \\
\text { leadott } \\
\text { voksok } \\
\text { számának } \\
\text { aránya az } \\
\text { országos } \\
\text { átlaghoz } \\
\text { viszonyítva }\end{array}$ &,- 069 &,- 036 &, 025 &,- 023 &,- 146 &, 001 & ,224 & ,261 & ,280 &,- 275 & ,260 \\
\hline
\end{tabular}

Forrás: Nemzeti Választási Iroda adatai alapján saját számítás és szerkesztés

A Spearman rangkorrelációs számításból kirajzolódott, hogy a városias kerületek magasabb részvétele okozta a kisebb pártoknak kedvezőtlenebb helyzetet, mivel az urbánusrurális tengelyen közepes a pozitív rangkorreláció értéke, ez 2002-ben 0,671, 2006-ban 0,626, míg 2010-ben 0,560 volt. Ha ezt parciálisan összevetjük a pártok 2002 és 2010 közötti beágyazottságával tudományos jelentőségü, hogy nem kedvezett szignifikánsan egyik nagypártnak sem a rendszer.

Tehát a korábbi választókerületi beosztásban rejlö területi aránytalanság nem játszott lényeges szerepet a pártok sikerességében. Gyenge pozitív és negatív korrelációkat tapasztaltam, és ez is a kisebb rétegpártoknál volt kimutatható, míg a nagypártok közül egyiknek sem kedvezett a választókerületek bárminemü méretbeli eltérése. Ez az új választási 
törvényben kialakított kerületi beosztásban megváltozott, és 2014-ben és 2018-ban is szignifikánsabb együttmozgások voltak tapasztalhatók (19. ábra, 13. táblázat).

A Pearson korrelációs értékekből, a 2014-es és 2018-as eredmények tükrében megállapítható, hogy a választásra jogosultak választókerületi eloszlásának szignifikáns összefüggése csak a Fidesz-KDNP listájával volt, negatív előjelű. Tehát a területi aránytalanság, valamint ennek részvétellel és a mandátumkiosztásba kerülő listaszavazattal súlyozott tényezője enyhe mértékben a jelenlegi kormányzó pártoknak kedvezett, míg a többi pártot nem hozta helyzetbe, de nem is gátolta az érvényesülésben. Erre a tényezőre ható demográfiai változások erejét mutatja, hogy 2014 és 2018 között csökkent a Fidesz-KDNP és a választásra jogosultak arányai közötti negatív közepes korreláció.

19. ábra: Pearson korrelációs összefüggések iránya a jelenlegi választókerületi rendszerben a pártok listás eredményei és a választásra jogosultak, választáson résztvevők, valamint a parlamentbe bejutott pártokra leadott listás voksok alapján

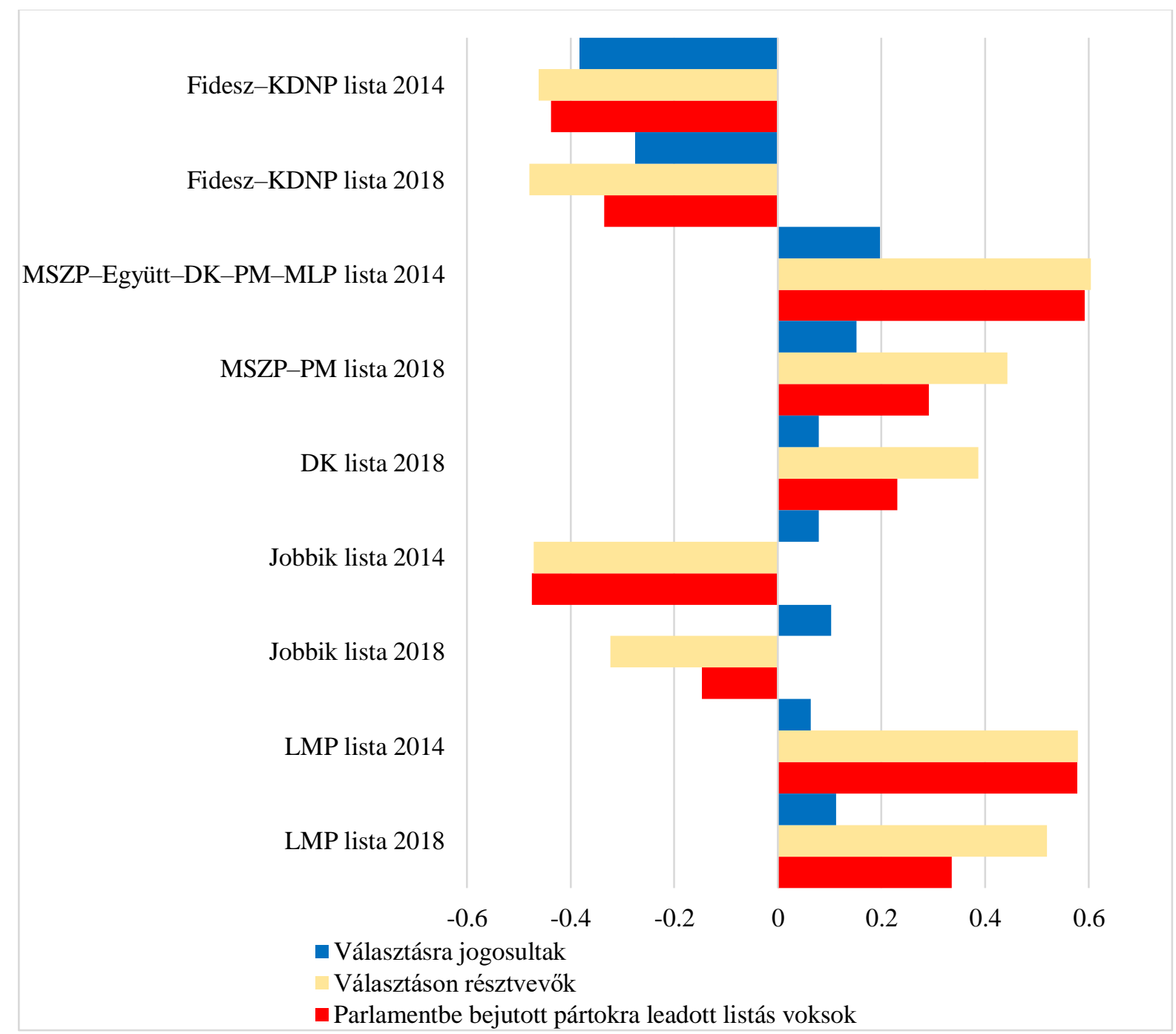

Forrás: Nemzeti Választási Iroda adatai alapján saját számítás és szerkesztés 
13. táblázat A 2014-es, a 2018-as pártlistás eredmények, a területi aránytalanság és reactive malapportionment tényezői közötti Pearson, valamint Spearman (*-al jelölve a táblázatban) korrelációs értékek

\begin{tabular}{|c|c|c|c|c|c|c|c|c|c|}
\hline $\begin{array}{c}\text { Választókerületek } \\
\text { 2014, } 2018\end{array}$ & $\begin{array}{c}\text { Fidesz- } \\
\text { KDNP } \\
\text { lista } \\
2014\end{array}$ & $\begin{array}{c}\text { Fidesz- } \\
\text { KDNP } \\
\text { lista } \\
2018\end{array}$ & $\begin{array}{c}\text { MSZP- } \\
\text { Együtt- } \\
\text { DK- } \\
\text { PM- } \\
\text { MLP } \\
\text { lista } \\
2014\end{array}$ & $\begin{array}{c}\text { MSZP- } \\
\text { PM lista } \\
\\
2018\end{array}$ & $\begin{array}{l}\text { DK } \\
\text { lista } \\
2018\end{array}$ & $\begin{array}{l}\text { Jobbik } \\
\text { lista } \\
2014\end{array}$ & $\begin{array}{l}\text { Jobbik } \\
\text { lista } \\
2018\end{array}$ & $\begin{array}{l}\text { LMP } \\
\text { lista } \\
2014\end{array}$ & $\begin{array}{l}\text { LMP } \\
\text { lista } \\
2018\end{array}$ \\
\hline Urbánus-rurális* &,- 480 &,- 629 & ,659 & ,651 & ,640 &,- 599 &,- 580 & ,700 & ,681 \\
\hline $\begin{array}{l}\text { Választásra } \\
\text { jogosultak } \\
\text { számának aránya } \\
\text { az országos } \\
\text { átlaghoz } \\
\text { viszonyítva }\end{array}$ &,- 383 &,- 276 & , 197 & ,152 & ,079 & ,079 & , 103 &, 064 &, 113 \\
\hline $\begin{array}{l}\text { Választáson } \\
\text { résztvevőkk } \\
\text { számának aránya } \\
\text { az országos } \\
\text { átlaghoz } \\
\text { viszonyítva }\end{array}$ &,- 462 &,- 479 & ,604 & ,443 & ,387 &,- 471 &,- 323 &, 579 &, 519 \\
\hline $\begin{array}{l}\text { Parlamentbe } \\
\text { bejutott pártokra } \\
\text { leadott voksok } \\
\text { számának aránya } \\
\text { az országos } \\
\text { átlaghoz } \\
\text { viszonyítva }\end{array}$ &,- 438 &,- 335 & ,592 & ,292 &, 230 &,- 475 &,- 147 &, 578 &, 336 \\
\hline
\end{tabular}

Forrás: Nemzeti Választási Iroda adatai alapján saját számítás és szerkesztés

Ha a jelenleg hatályos választókerületi beosztás eltéréseit a részvétellel is súlyozzuk, akkor már jelentős, elsőre fel nem fedezhető egyenlőtlenség tapasztalható az új választási rendszerben. Egyrészt a Fidesz-KDNP esetében felerősödtek a kedvező tényezők, hiszen jól teljesítettek olyan kerületekben, ahol kevesebb szavazó produkált alacsonyabb aktivitást, és rosszabbul ott, ahol több szavazó nagyobb részvételt mutatott. Másrészt megfigyelhető a szimpla területi aránytalanság súlyozását követően, hogy eltünik a rendszer semleges hatása, és az összes ellenzéki pártra egy negatív hatás mutatható ki. A korrelációs értékekből arra következtethetünk, hogy míg a Jobbikot kismértékben, de pozitívan támogatta az új térfelosztás, addig a balliberális oldalhoz kapcsolható pártokat már egyértelmủen hátrányosan érintette, igaz ennek mértéke csökkent 2018-ra. Az LMP esetében már közepesen pozitív korreláció tapasztalható, és ez változatlanul negatívan érintette a térfelosztásból adódó igazságtalanságot. 
Ennek oka a megalkotott rendszer mellett az, hogy ha időrendileg összevetjük a választókerületi szintü együttmozgásokat, akkor kirajzolódik a város és vidéke társadalmi törésvonal felerösödése, főleg a Fidesz-KDNP tekintetében. Míg a MSZP-PM és DK, Együtt pártok és az új politikai formációk támogatottságuk jelentős részét koncentráltan a nagyvárosi kerületekben szerezték, ahol jelentős rivalizálás alakult ki a támogatottságért, addig vidéken egyértelmü volt a Fidesz-KDNP elönye, s a Jobbikot leszámítva a többi ellenzéki párt teljesen súlytalanná vált. A számítások azt támasztják alá, hogy a korábbi beosztással összevetve nem változott érdemben az urbánus és rurális választókerületek és a részvétel közötti rangkorreláció mértéke sem. Amíg ez az érték 2014-ben 0,603 volt, 2018-ra 0,537-re csökkent. Mivel ez az érték 2010 előtt is hasonló volt, így azt is bizonyítja, hogy az új kerületek megrajzolásának nagy befolyása volt arra, hogy melyik pártokat hozza helyzetbe vagy érinti hátrányosan.

A választásokon a részvétel megmutatja, hogy hány szavazó nyilvánítja ki véleményét, azonban nem minden voks (érvénytelen, parlamentbe nem jutott pártra vagy jelöltre leadott szavazat stb.) kerül számításba. Ezek kivételével tovább lehet árnyalni a földrajzi torzulás eme tényezőjét. Ezért, ha tovább súlyozzuk az értékeket az értéktelen voksokkal, tovább árnyalhatjuk a képet és hangsúlyozhatjuk a választók szerepét a térbeli egyenlötlenségek alakításában. Az eredményekből alapvetöen az következik, hogy míg 2014-ben nincs nagy különbség a részvétellel súlyozott értékhez képest, addig 2018-ra a kormányzó pártszövetségnek jelentősen csökken az elönye, míg a Jobbiknak megszünik. Miközben az MSZP-PM, LMP és DK hátránya érezhetően oldódik. Ennek oka az ellenzéki politikai erők széttartása és a szavazatok jelentős elaprózódása, főleg a fővárosban. Emellett a parlamentbe nem jutó pártokra leadott voksok 2014-ben még a leadott listás szavazatok 3,63\%-át, addig 2018-ban már 7,32 \%-át tették ki. Ezen formációkra leadott voksok (pl. Momentum, MKKP) pont ott koncentrálódtak, ahol eleve magasabb volt a választásra jogosultak száma és a megjelentek aránya is. Tehát a részvétel jelentősen felerősítette a területi aránytalanságot, de az értéktelen voksok kisebb mértékben mérsékelték azt.

Összességében megállapítható, hogy a választásra jogosultak kerületenként tapasztalt eltérései csak az alapvető területi egyenlőtlenségeket mutatta ki. Így a hazai országgyülési választások vizsgálatánál a területi aránytalanságok elemzésénél szükségszerü a mögöttes demográfiai folyamatokat is vizsgálni, illetve ezt a részvételi arányokkal, valamint a mandátumkiosztásba kerülö szavazatok eltéréseivel is kiegészíteni. Az eredményekből az is kirajzolódott, hogy míg a korábbi beosztás szignifikánsan csak a kisebb pártok eredményességére hatott, az új lehatárolás egyenlőtlenségei már a Fidesz-KDNP pártszövetséget támogatták mérsékelt korrelációval. Azonban az igazi torzulás a súlyozott értékeknél tünik ki különösen, és ez a jobboldali pártokat hozta helyzetbe, míg a baloldali, liberális és zöld pártokat szignifikánsan gyengítette. Tehát az esetleges manipulációs szándék mellett a szavazók pártpreferenciái és aktív szerepvállalása (pl. szomszédsági hatás) is felerősítette a magyar rendszer eme földrajzi torzulását. Ez azonban már szorosan összefügg a megvalósult földrajzi torzulást okozó gerrymandering tényezőivel is, hiszen, ha változik a pártpreferencia akkor automatikusan a reactive malappotionemt is módosul, átalakítva a választási rendszer mandátumkiosztási mechanizmusait. Ebből adódóan a következő részben a pártok térbeli beágyazottságát kívánom elemezni és végül a gerrymandering mértékét és a mandátumkiosztásban betöltött szerepét próbálom meghatározni. 


\subsection{Gerrymandering a magyar országyülési választási rendszerben}

A korábban bemutatott klaszterelemzés által meghatározott csoportok kirajzolták a pártok politikai földrajzi beágyazottságát és annak változásait, ugyanakkor a malapportionment mellett a pártok támogatottságának földrajzi koncentrációja is utalhat a gerrymandering meglétére és mértékére. Ebben a fejezetben vizsgálom a magyar választási rendszerekben lévő gerrymandering erejét és az erre ható tényezőket 2002 és 2018 között. Ezután a települési szint elemzésével a választókerületeken belüli alapvető választásföldrajzi típusokat is igyekszem kimutatni.

Fontos megállapítani, hogy a módosítható területi egység kérdéskörét hazánkban a jobboldali és a baloldali szavazók választókerületi és települési szintü koncentrációjának időbeli összemérésénél is figyelembe kell venni (DUSEK T. - KoTOSZ B. 2016). Ebből adódóan a régi és új beosztásra számolt adatokat nem lehet egy az egyben megfeleltetni, hanem az összehasonlításhoz a két különböző lehatárolásban az egyes pártok indexeit és annak változásait is viszonyítani kell egymáshoz és korábbi eredményeikhez is. Az elméletben kifejtett angolszász modell (JOHNSTON R. 2002a, b) azt mondja, hogy ideális az az állapot, ha egy pártnak egyenletes a támogatottsága a választókerületekben, mert ez adja meg a legnagyobb esélyt a mandátumok megszerzésre és a választások megnyerésére. Azonban ez a logika feltételezi a szoros versenyt több nagypárt között, ami hazánkban a vizsgált választásokon csak a 2002-ben és 2006-ban volt igaz. Ezután 2010-re átalakult a magyar választói magatartás és egy domináns pártszövetség mellett több közepes-, és kispárt lett hazánkban, amiben már a kisebb pártok koncentrált szavazateloszlása inkább kedvezőtlen a mandátumszerzés szempontjából. Ebből adódóan ezt is figyelembe veszem a homogén és kevert gerrymandering tényezőinek elemzése során. Mindezt figyelembe véve a 2011 előtti felosztásban tapasztalható gerrymandering alapvető típusairól és a pártok térbeli eloszlásáról a relatív szórás, a Herfindahl-Hirschman-, és a Hoover-indexek számolnak be (15. táblázat).

Mindegyik regionális elemzési módszerrel számított eredményből megállapítható, hogy a korábbi választókerületi beosztásban 2002-ben és 2006-ban is a térben legjobb mértékben kiegyensúlyozott támogatottsággal az MSZP rendelkezett. A Hoover index alapján 2002-ben a szavazók 6,04\%-át kellett volna átcsoportosítani a tökéletesen egyenletes eloszlásért, 2006-ra ez az index már nagyobb értéket $(6,27 \%)$ mutatott. A variációs együttható esetében a két nagypárt szinte hasonló értékeket ért el, míg az SZDSZ 2006-ra nagyobb relatív szórást produkált. A koncentrációt mérő Herfindahl-Hirschman index arra világított rá, hogy 2006-ra az MSZP eleve alacsony homogenizáltsága csökkent, míg a riválisának növekedett a négy évvel korábbi értékhez képest. Tehát a három regionális elemzési módszer is hasonló folyamatokról árulkodott. Ebből adódóan az akkori kétpólusú pártstruktúrát és a támogatottságokat figyelembe véve a régebbi választási rendszer gerrymandering tényezője a szocialista pártnak kedvezett 2002-ben és 2006-ban egyaránt. A versenyelöny abból eredt, hogy a Fidesz-MDF és MSZP közel azonos országos szavazataránya és szoros versenye mellett a szocialisták támogatottsága egyenletesebben oszlott el a választókerületek között, így nagyobb esélyük volt mandátumot szerezni és győzni.

Megállapítható, hogy az SZDSZ támogatottsága 2002-ben és 2006-ban egyaránt nagyon egyenlőtlen volt a választókerületekben, hiszen a rájuk leadott voksok nagy hányadát kellett volna újraosztani, hogy leképezzék az egyenletes támogatottságot. Azonban, ha figyelembe vesszük az országos eredményüket, akkor a szavazóik jelentős koncentrációja figyelhető meg, így a homogén gerrymandering jelensége segítette az SZDSZ mandátumszerzését mindkét választáson. Amíg az SZDSZ listája kiugróan koncentrálódott néhány választókerületben addig az MDF kispárt létére 2006-ban sokkal egyenletesebb térbeli támogatottságot mutatott fel. 
14. táblázat: A parlamentbe bejutott pártok listáinak Variációs együtthatói, Herfindahl-Hirschman és Hoover indexei 2002 és 2010 között

\begin{tabular}{cccccccc}
\hline $\begin{array}{c}\text { Választókerületek } \\
\text { gerrymandering } \\
\text { tényezői }\end{array}$ & $\begin{array}{c}\text { Fidesz- } \\
\text { MDF lista }\end{array}$ & $\begin{array}{c}\text { Fidesz- } \\
\text { KDNP } \\
\text { lista }\end{array}$ & $\begin{array}{c}\text { MSZP } \\
\text { lista }\end{array}$ & $\begin{array}{c}\text { SZDSZ } \\
\text { lista }\end{array}$ & $\begin{array}{c}\text { MDF } \\
\text { lista }\end{array}$ & $\begin{array}{c}\text { Jobbik } \\
\text { lista }\end{array}$ & $\begin{array}{c}\text { LMP } \\
\text { lista }\end{array}$ \\
& & & &
\end{tabular}

2002, 2006, 2010

\begin{tabular}{|c|c|c|c|c|c|c|c|}
\hline $\begin{array}{c}\text { Variációs } \\
\text { együttható } 2002\end{array}$ & 0,25 & - & 0,24 & 0,61 & - & - & - \\
\hline $\begin{array}{c}\text { Variációs } \\
\text { együttható } 2006\end{array}$ & - & 0,25 & 0,24 & 0,67 & 0,31 & - & - \\
\hline $\begin{array}{c}\text { Variációs } \\
\text { együttható } 2010\end{array}$ & - & 0,25 & 0,34 & - & - & 0,34 & 0,59 \\
\hline $\begin{array}{l}\text { Herfindahl- } \\
\text { Hirschman-index } \\
2002\end{array}$ & 60,26 & - & 60,11 & 78,06 & - & - & - \\
\hline $\begin{array}{l}\text { Herfindahl- } \\
\text { Hirschman-index } \\
2006\end{array}$ & - & 60,49 & 60,00 & 81,96 & 62,39 & - & - \\
\hline $\begin{array}{l}\text { Herfindahl- } \\
\text { Hirschman-index } \\
2010\end{array}$ & - & 60,44 & 63,22 & - & - & 63,30 & 76,27 \\
\hline $\begin{array}{l}\text { Hoover-index } \\
2002\end{array}$ & $8,18 \%$ & - & $6,04 \%$ & $19,65 \%$ & - & - & - \\
\hline $\begin{array}{l}\text { Hoover-index } \\
2006\end{array}$ & - & $7,21 \%$ & $6,27 \%$ & $21,4 \%$ & $7,16 \%$ & - & - \\
\hline $\begin{array}{l}\text { Hoover-index } \\
2010\end{array}$ & - & $5,37 \%$ & $9,89 \%$ & - & - & $13,95 \%$ & $19,38 \%$ \\
\hline
\end{tabular}

Forrás: Nemzeti Választási Iroda adatai alapján saját számítás és szerkesztés 
Az MDF így szinte a két nagypárt szavazóinak térbeli tulajdonságát mutatta fel. Azonban ez az előző analógiára vetítve inkább versenyhátrányt okozott a pártnak, hiszen a földrajzi tényezők miatt igazán sehol nem kerültek alkupozícióba és így esetleges mandátumszerzés közelébe. Tehát a 2002-es és 2006-os választásokon a választókerületi beosztás gerrymandering tényezői igazán az MSZP és SZDSZ pártokat hozta helyzetbe, míg a Fidesz-KDNP és az MDF hátrányt szenvedett.

Az iménti módszerek mellett a különböző földrajzi léptéken számolt súlyozott és súlyozatlan Gini-indexek hasonló folyamatokról árulkodtak. Azonban a választókerületi és települési értékek közötti különbségek kimutatása a módosítható területi egység problémáját és a szavazók aktív szerepét is kiemelték (15. táblázat). Fontos megállapítani, hogy 2002 és 2010 között az országgyülési választáson győztes nagypárt települési szinten is a legegyenletesebb támogatottságot élvezte, ami miatt a választókerületekben is esélyes volt. Ez alátámasztotta, hogy a választók is aktívan befolyásolják a gerrymandering természetét.

Ha a települési értékeket szeretnénk arányosan összevetni a választókerületi indexekkel akkor a súlyozott Gini együtthatókat érdemes összehasonlítani, hiszen ott az érvényes szavazatokkal van összevetve a pártok támogatottsága. Így itt kisebb értékeket tapasztalhatunk és a települési és kerületi eloszlás közötti különbségek a beosztás módosító tényezőjére világítottak rá. A súlyozatlan értékek érdemben választókerületi szinten értelmezhetők jól, települési szinten a nagy különbségek (Budapest és Iborfia szavazói) miatt nagy egyenlőtlenségeket lehetett tapasztalni.

Az indexekből az is megállapítható, hogy a Fidesz és az MSZP versenyében a 2002 és 2006 közötti eloszlásban rejlő különbségek más tendenciát mutattak. Amíg a súlyozatlan Giniindexek tekintetében növekedett az olló a két nagypárt között a szocialisták javára, addig a súlyozott értékeknél közeledést mutattak az értékek. Gyakorlati szempontból a mandátumokat a szavazatok számával lehet megnyerni, így kerületi szinten a gerrymandering szempontjából a súlyozatlan indexek mutatták a hatékony eloszlás pozitív hatását. Négy évvel később már a Fidesz-KDNP egyenletes eloszlása minden szinten minden indikátorral kimutatható volt.

2010-re tehát jelentősen átalakult a választói magatartás, s ezzel együtt a gerrymandering eshetősége is. A Fidesz-KDNP megtartotta és megerösítette támogatottságának kiegyensúlyozottságát, míg az MSZP elveszítette korábbi versenytárs szerepét, voksai jelentősen koncentrálódtak, ami viszont az új felállásban is mandátumszerzést eredményezett Budapesten. Tehát 2010-ben a hajdani választási beosztás gerrymandering tényezője a FideszKDNP sikerét erősítette, míg az MSZP számára már kedvezőtlenebbé vált a felosztás, amit ekkor mégcsak a választói magatartás átalakulása okozott.

A gerrymandering igazán a parlamentbe újonnan bekerülő pártok (de különösen az LMP) esetében mutatott nagy egyenlőtlenségeket, hiszen mindkét csoportosulás támogatóinak nagy hányadát kellett volna újra szétosztani az egyenletes eloszlásért. Érdekesség, hogy a súlyozatlan értékeknél a Jobbik választókerületi szinten koncentráltabb szavazótáborral rendelkezett, mint az MSZP, települési léptéken azonban ez fordított volt. Ennek oka a város-vidék törésvonalra vezethető vissza, hiszen a szocialisták a fővárosban és a nagyvárosokban szerepeltek jobban, míg a Jobbik inkább regionális párt képét mutatta. Ennek a térbeli sajátosságnak az oka, hogy 2010-ben a Jobbikot lehetett regionális támogatottságú pártnak nevezni, azonban ez inkább az etnikai társadalmi törésvonalon alapuló mozgósítás eredménye volt (BERTUS Z. 2016 b, 2017, SZABÓ B. 2013, VIDA Gy. 2014). Az LMP tovább örökítette az SZDSZ korábbi eloszlásbéli egyenlőtlenségeit. A közepes-, és kispártok révén a koncentráció még kedvező is volt a mandátumszerzési esélyek szempontjából. 
15. táblázat A parlamentbe bejutott pártok listáinak választókerületi és települési szintü Gini-indexei 2002 és 2010 között

\begin{tabular}{|c|c|c|c|c|c|c|c|}
\hline $\begin{array}{l}\text { Választókerületek } \\
\text { gerrymandering } \\
\text { tényezői }\end{array}$ & $\begin{array}{l}\text { Fidesz- } \\
\text { MDF } \\
\text { lista }\end{array}$ & $\begin{array}{l}\text { Fidesz- } \\
\text { KDNP } \\
\text { lista }\end{array}$ & $\begin{array}{l}\text { MSZP } \\
\text { lista }\end{array}$ & $\begin{array}{c}\text { SZDSZ } \\
\text { lista }\end{array}$ & $\begin{array}{l}\text { MDF } \\
\text { lista }\end{array}$ & $\begin{array}{c}\text { Jobbik } \\
\text { lista }\end{array}$ & $\begin{array}{l}\text { LMP } \\
\text { lista }\end{array}$ \\
\hline
\end{tabular}

2002, 2006, 2010

\begin{tabular}{|c|c|c|c|c|c|c|c|}
\hline $\begin{array}{c}\text { Gini-index } \\
\text { OEVK } 2002\end{array}$ & $13,89 \%$ & - & $13,52 \%$ & $31,98 \%$ & - & - & - \\
\hline $\begin{array}{c}\text { Gini-index } \\
\text { OEVK } 2006\end{array}$ & - & $14,47 \%$ & $13,24 \%$ & $34,90 \%$ & $17,69 \%$ & - & - \\
\hline $\begin{array}{l}\text { Gini-index } \\
\text { OEVK } 2010\end{array}$ & - & $14,23 \%$ & $18,84 \%$ & - & - & $19,11 \%$ & $32,36 \%$ \\
\hline $\begin{array}{c}\text { Gini-index } \\
\text { település } 2002\end{array}$ & $73,84 \%$ & - & $79,93 \%$ & $87,04 \%$ & - & - & - \\
\hline $\begin{array}{l}\text { Gini-index } \\
\text { település } 2006\end{array}$ & - & $74,54 \%$ & $79,11 \%$ & $88,67 \%$ & $80,95 \%$ & - & - \\
\hline $\begin{array}{l}\text { Gini-index } \\
\text { település } 2010\end{array}$ & - & $74,82 \%$ & $82,74 \%$ & - & - & $76,21 \%$ & $87,49 \%$ \\
\hline $\begin{array}{c}\text { Súlyozott Gini- } \\
\text { index OEVK } \\
2002\end{array}$ & $11,32 \%$ & - & $8,60 \%$ & $27,02 \%$ & - & - & - \\
\hline $\begin{array}{c}\text { Súlyozott Gini- } \\
\text { index OEVK } \\
2006\end{array}$ & - & $9,93 \%$ & $8,80 \%$ & $29,78 \%$ & $10,24 \%$ & - & - \\
\hline $\begin{array}{l}\text { Súlyozott Gini- } \\
\text { index OEVK } \\
2010\end{array}$ & - & $7,38 \%$ & $13,78 \%$ & - & - & $18,98 \%$ & $26,21 \%$ \\
\hline $\begin{array}{l}\text { Súlyozott Gini- } \\
\text { index település } \\
\qquad 2002\end{array}$ & $13,30 \%$ & - & $10,67 \%$ & $30,15 \%$ & - & - & - \\
\hline $\begin{array}{l}\text { Súlyozott Gini- } \\
\text { index település } \\
2006\end{array}$ & - & $12,18 \%$ & $10,86 \%$ & $32,58 \%$ & $14,62 \%$ & - & - \\
\hline $\begin{array}{l}\text { Súlyozott Gini- } \\
\text { index település } \\
\qquad 2010\end{array}$ & - & $8,99 \%$ & $16,98 \%$ & - & - & $21,27 \%$ & $28,48 \%$ \\
\hline
\end{tabular}

Forrás: Nemzeti Választási Iroda adatai alapján saját számítás és szerkesztés 
Összegezve az előző választókerületi beosztás gerrymandering tényezőit és a pártok országos mandátumszerzési esélyeit megállapítható, hogy a versengő nagypártoknál kedvező az egyenletes eloszlás, míg a közepes-, és kispártoknak a koncentrált támogatottság hoz potenciálisan nagyobb reprezentációt. Ebből a logikából következik, hogy 2002-ben az MSZPt és az SZDSZ-t hozta jó helyzetbe a rendszer, míg a Fidesz-MDF versenyhátrányt szenvedett. 2006-ban szintén a szocialista és a liberális párt profitált inkább a térbeli hatásokból, míg a Fidesz-KDNP és az MDF hátrányba került. 2010-re fordult a kocka, a választási rendszer változatlansága mellett a Fidesz-KDNP nagy haszonélvezője lett a gerrymandering hatásának, míg az MSZP középpárttá zsugorodása révén mérsékelt hátrányt szenvedett. A Jobbik és az LMP országos eredményeiből levezetve még pozitív volt szavazóinak térbeli sürüsödése.

2014-re csökkent a kerületek száma és a határokat is jelentősen átrajzolták. Ebből adódóan az új beosztásban - mivel nagyobb az átlagos területi lépték - a korábbival összevetve a kisebb értékek is nagyobb torzítást mutathatnak (16. táblázat). Értelmezés szempontjából hasonló a logika, a Fidesz-KDNP esetében a minél alacsonyabb érték okoz versenyelőnyt, míg a közepes- és kispártoknak a nagyobb koncentráció és egyenlötlenség kecsegtet gyakorlati haszonnal. A variációs együttható, a Herfindahl-Hirschman-, és a Hoover- index értékei is hasonló tendenciákat mutattak a 2014-es és 2018-as eredmények alapján.

16. táblázat: A parlamentbe bejutott pártok listáinak Variációs együtthatói, Herfindahl-Hirschman és Hoover indexei 2014 és 2018 között

\begin{tabular}{|c|c|c|c|c|c|c|}
\hline $\begin{array}{l}\text { Választókerületek } \\
\text { gerrymandering } \\
\text { tényezői } \\
2014,2018\end{array}$ & $\begin{array}{l}\text { Fidesz- } \\
\text { KDNP } \\
\text { lista }\end{array}$ & $\begin{array}{c}\text { MSZP- } \\
\text { Együtt- } \\
\text { DK-- } \\
\text { PM- } \\
\text { MLP } \\
\text { lista }\end{array}$ & $\begin{array}{c}\text { MSZP- } \\
\text { PM } \\
\text { lista }\end{array}$ & $\begin{array}{r}\text { DK } \\
\text { lista }\end{array}$ & $\begin{array}{l}\text { Jobbik } \\
\text { lista }\end{array}$ & $\begin{array}{l}\text { LMP } \\
\text { lista }\end{array}$ \\
\hline $\begin{array}{c}\text { Variációs } \\
\text { együttható } 2014\end{array}$ & 0,13 & 0,34 & - & - & 0,27 & 0,53 \\
\hline $\begin{array}{c}\text { Variációs } \\
\text { együttható } 2018\end{array}$ & 0,14 & - & 0,38 & 0,42 & 0,24 & 0,47 \\
\hline $\begin{array}{l}\text { Herfindahl- } \\
\text { Hirschman-index } \\
2014\end{array}$ & 95,90 & 105,18 & - & - & 101,30 & 120,76 \\
\hline $\begin{array}{l}\text { Herfindahl- } \\
\text { Hirschman-index } \\
2018\end{array}$ & 96,09 & - & 107,91 & 110,84 & 99,95 & 115,00 \\
\hline $\begin{array}{l}\text { Hoover-index } \\
2014\end{array}$ & $5,21 \%$ & $10,46 \%$ & - & - & $12,25 \%$ & $18,44 \%$ \\
\hline $\begin{array}{l}\text { Hoover-index } \\
2018\end{array}$ & $6,11 \%$ & - & $12,48 \%$ & $14,23 \%$ & $10,29 \%$ & $15,89 \%$ \\
\hline
\end{tabular}

Forrás: Nemzeti Választási Iroda adatai alapján saját számítás és szerkesztés 
Megállapítható, hogy 2014-re a gerrymandering formálásában már közrejátszott az átszabott beosztás is. A 2010-es országos eredményhez képest az ellenzék javítani tudott, mégis a térbeli eloszlás szempontjából a Fidesz-KDNP szavazótábora oszlott el a leghatékonyabban a választókerületek között, ők indultak a legjobb eséllyel az összes egyéni mandátum megszerzéséért. Kimutatható, hogy a súlyozott értékekben a leghatékonyabb eloszlást települési szinten is a Fidesz-KDNP produkálta (KovÁCS, Z. - VIDA, GY. 2018), így a gerrymandering tényezőjében a kerületi lehatárolás mellett a választók szerepe is fajsúlyos maradt. Míg az MSZP-Együtt-DK-PM-MLP magasabb támogatottságot szerzett mint 2010ben az MSZP, a Hoover-index magasabb egyenlötlenségre utal, ami azért is nagy változás, mert a kerületek száma is csökkent. Így gyakorlati szempontból tudtak mandátumot szerezni a nagy koncentrációval, viszont egy szorosabb versenyben a földrajzi lehatárolás ellenük dolgozott volna. Ha a súlyozott és súlyozatlan Gini-indexeket is kiszámoljuk települési és választókerületi szinten további összefüggéseket is meghatározhatunk (17. táblázat).

17. táblázat A parlamentbe bejutott pártok listáinak választókerületi és települési szintű Gini-indexei 2014 és 2018 között

\begin{tabular}{|c|c|c|c|c|c|c|}
\hline & $\begin{array}{l}\text { Fidesz- } \\
\text { KDNP } \\
\text { lista }\end{array}$ & $\begin{array}{c}\text { MSZP- } \\
\text { Együtt- } \\
\text { DK-- } \\
\text { PM- } \\
\text { MLP } \\
\text { lista }\end{array}$ & $\begin{array}{l}\text { MSZP- } \\
\text { PM lista }\end{array}$ & DK lista & $\begin{array}{l}\text { Jobbik } \\
\text { lista }\end{array}$ & $\begin{array}{l}\text { LMP } \\
\text { lista }\end{array}$ \\
\hline $\begin{array}{c}\text { Gini-index } \\
\text { OEVK } 2014\end{array}$ & $7,22 \%$ & $18,85 \%$ & - & - & $15,01 \%$ & $29,05 \%$ \\
\hline $\begin{array}{c}\text { Gini-index } \\
\text { OEVK } 2018\end{array}$ & $7,79 \%$ & - & $20,33 \%$ & $22,65 \%$ & $13,65 \%$ & $25,57 \%$ \\
\hline $\begin{array}{l}\text { Gini-index } \\
\text { település } 2014\end{array}$ & $75,26 \%$ & $84,67 \%$ & - & - & $75,23 \%$ & $88,70 \%$ \\
\hline $\begin{array}{l}\text { Gini-index } \\
\text { település } 2018\end{array}$ & $75,18 \%$ & - & $86,20 \%$ & $87,16 \%$ & $78,20 \%$ & $88,69 \%$ \\
\hline $\begin{array}{c}\text { Súlyozott Gini- } \\
\text { index OEVK } \\
2014\end{array}$ & $7,27 \%$ & $14,20 \%$ & - & - & $17,02 \%$ & $24,98 \%$ \\
\hline $\begin{array}{c}\text { Súlyozott Gini- } \\
\text { index OEVK } \\
2018\end{array}$ & $8,34 \%$ & - & $16,67 \%$ & $19,19 \%$ & $14,41 \%$ & $21,51 \%$ \\
\hline $\begin{array}{l}\text { Súlyozott Gini- } \\
\text { index település } \\
2014\end{array}$ & $9,78 \%$ & $17,50 \%$ & - & - & $19,29 \%$ & $28,30 \%$ \\
\hline $\begin{array}{l}\text { Súlyozott Gini- } \\
\text { index település } \\
\qquad 2018\end{array}$ & $10,52 \%$ & - & $19,77 \%$ & $22,50 \%$ & $16,20 \%$ & $24,31 \%$ \\
\hline
\end{tabular}

Forrás: Nemzeti Választási Iroda adatai alapján saját számítás és szerkesztés 
Ha Gini-indexekkel elvégezzük az összes kerület összehasonlítását, megállapíthatjuk, hogy a Jobbik listája is egyenletesebb eredményt mutatott az MSZP-Együtt-DK-PM-MLP összefogásánál, ha a súlyozatlan értéket nézzük. Ha a súlyozott értéket vesszük akkor a balliberális oldalhoz kapcsolódó pártok már egyenletesebben oszlottak el. Az LMP megőrizte szavazóinak az előző választókerületi beosztásból fennmaradt extrém koncentráltságát. Így tehát éles versenyben kimutatható mértékben a balliberális ellenzék ellen dolgozott volna a felosztás, még ha önmaguk korábbi értékeihez hasonlítjuk az értékeket, akkor is versenyhátrányt fedezhettünk fel. A Fidesz-KDNP 2010 után majdnem megfelezte a Giniindex értékét, stabilan biztosítva a kerületekben lévő támogatottságának kiegyensúlyozottságát. A Jobbik is egyenletesebben oszlott el, így éles versenyhelyzetben öket is segítette volna a térbeliség a mandátumok elnyerésében, viszont a 2014-es végeredmények tükrében még a balliberális oldallal szemben is hátrányba kerültek.

2018-ra az országos pártpolitika átrendeződése ellenére érdemi változás nem következett be. A Fidesz-KDNP megerősödése nem volt olyan hatékony, mint 2014-ben, a Jobbik pedig országos stagnálás mellett még egyenletesebb eloszlást mutatott. Ez éles versenyben kedvező tulajdonság lenne, de tetemes lemaradása volt a kormányzópártokhoz képest, így mandátumszerzési esélyei ismét csekélyek voltak. Így a közepes-, és kispártok szempontjából, ami éles versenyben hátrány lenne, az 2018 gyakorlatában ismét előny volt. Az LMP, de föként az MSZP-PM és a DK szavazótáborának erőteljes koncentrációja és ebből adódó alkupozíciója az, ami miatt több egyéni mandátumot tudtak szerezni, ez a Jobbik esetében az egyenletesebb támogatói eloszlás miatt nem volt elmondható. Azonban a kerületek térfelosztása mellett a gerrymandering mértékét a választói magatartáson keresztül a társadalmi háttérfolyamatok is formálták.

Ha a települési Gini-indexeket is vizsgáljuk a 2002 és 2010 közötti adatokhoz hasonlóan, a győztes pártok kisebb területi szinten is a leghatékonyabban szerepeltek. Az ellenzék esetében a Jobbikot leszámítva térbeli koncentrálódás ment végbe 2014 és 2018 között. Ez arra enged következtetni, hogy kevesebb területen, de nagyobb eséllyel indulnak a pártok a mandátumért, ami annyit jelent, hogy az ellenzéki jelöltek felállításánál az összefogásban résztvevő politikai csoportok helyi koncentrációja fogja meghatározni a győzelmi esélyeket. Tehát az urbanizált területeken a balliberális pártoknak kellene indulni, míg a vidéki területeken a Jobbiknak nyílnak esélyei legyőzni a Fidesz-KDNP jelöltjeit. A 2018-as eredmények alapján a választókerületek felében az összesített ellenzék több voksot szerzett, mint a kormányzó pártok. Ez kiélezett duális pártversenyt hozhat 2022-ben.

Mivel a nemzetközi és hazai földrajzi szakirodalom hangsúlyozza, hogy a választás térstruktúráinak feltárása mellett a társadalmi háttérfolyamatok vizsgálata is szükséges (HEGEDÜS G. 2007 b, MORILL, R. et al. 2007), ezért elemzésem során erre is kitértem. A politikai-társadalmi törésvonalak elméleti modelljéből (ANGELUSZ R. - TARDOS R. 2011, LIPSET, S. M. - RoKKAN, S. 1967, INGLEHART, R. 1977, WARF, B. 2011) levezetve a lakóhely, a társadalmi státusz, a vallás és az etnikai, nyelvi különbségek differenciáló hatásait mértem a 2011-es népszámlálási, valamint a 2014-es és 2018-as országgyülési választások pártlistás adatainak összevetésével.

Mivel a hazai választási eredményekben jól kimutatható a társadalmi törésvonalak véleményformáló szerepe (VIDA Gy. 2014, VIDA Gy. - KovalcsiK T. 2018), ezért ennek jelentős gerrymanderinget befolyásoló ereje volt 2014-ben és 2018-ban egyaránt. Továbbá a folyamatokat erősítették a pártok kampányai, a pártok közötti verseny szorossága, valamint a pártstruktúra beállása és az újonnan alakuló pártok lehetőségei is. Így tehát az eredmények tükrében megállapítható, hogy a voksolók által generált változás is jelentősen befolyásolta a 
szavazatok térbeliségét, aminek választói magatartásból eredő okát a pártlistás eredmények és a strukturális mutatók közötti korrelációk mutathatják meg (20. ábra).

20. ábra: A pártlistás eredmények és a strukturális mutatók közötti korrelációk változásának összetett pókháló diagramja

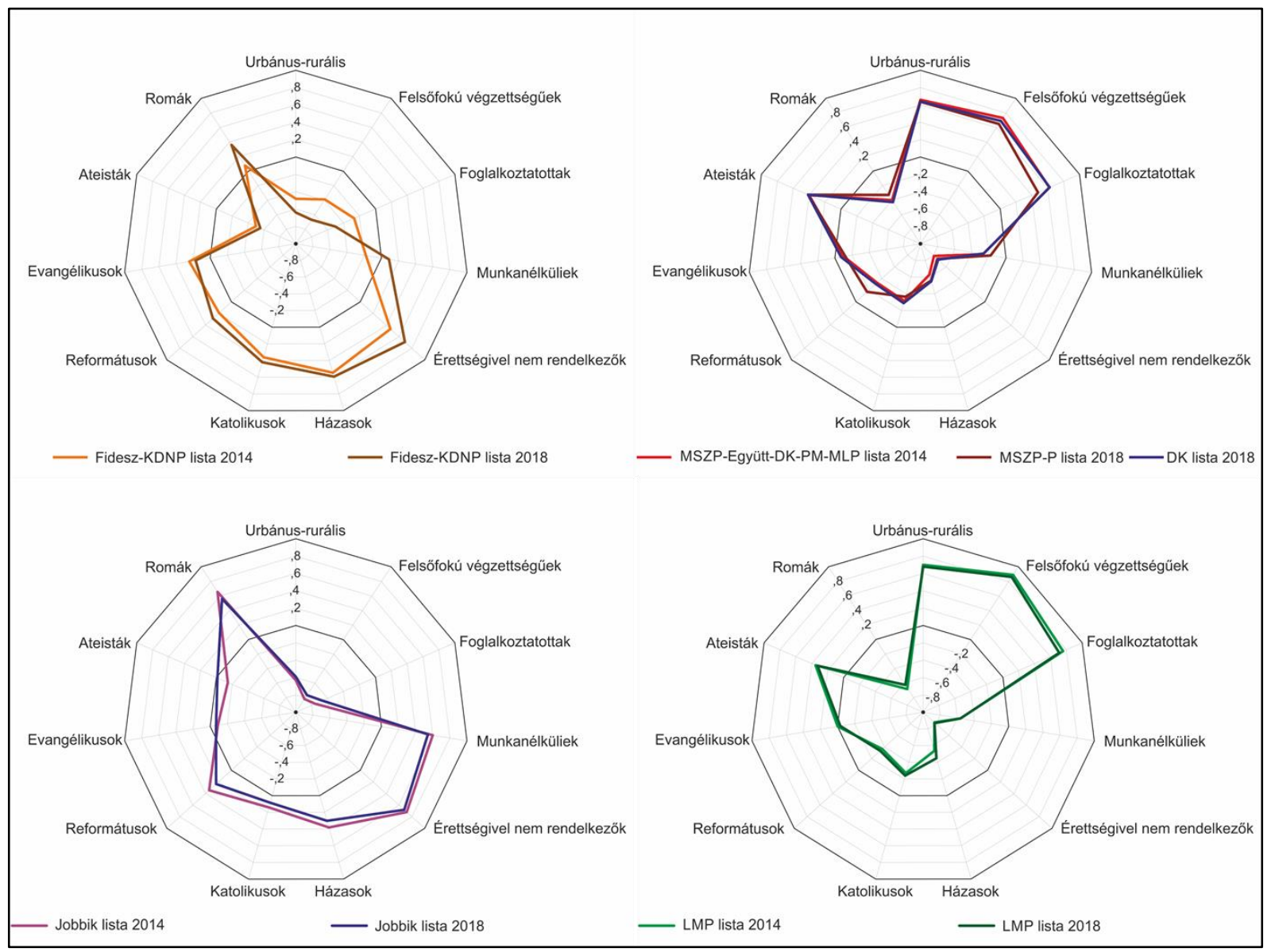

Forrás: Központi Statisztikai Hivatal, Nemzeti Választási Iroda adatai, Vida Gy. - Kovalcsik T. 2018 alapján saját számítás és szerkesztés

Az összefüggések politikai tartalmáról leszögezhető, hogy a felsőfokú végzettségűek fóként a városias, gazdaságilag versenyképesebb térségekben laknak magasabb arányban, hiszen több megfelelő állás van számukra. Ezeken a területeken ugyanakkor megtalálható a kulturális sokszínűség, és részben a multikulturalizmusból adódó innováció (BOROS, L. et al. 2016, Boros L. et al. 2017, FABUla, Sz. et al. 2017a, b, EGEDy, T. et al. 2018, KERESNYEI K. - EGEDY T. 2015). Így a balliberális pártok globalista értékközvetítése a nagyvárosokban volt népszerübb, míg a hátrányos gazdasági helyzetben lévő, rurális területeken inkább konfliktusok forrása volt az etnikai diverzitás, amire a szélsőjobboldal is építhetett. Ez az összefüggés nemzetközi példákban is fellelhető (SÜMEGHY D. - NÉMETH Á. 2018).

A változók közötti összefüggések vizsgálatakor kiderült, hogy a lakóhely nemcsak a pártválasztással, hanem más társadalmi mutatóval is szorosabb kapcsolatot mutatott, hiszen az iskolázottság és a foglalkoztatottság is magasabb volt az urbánus térségekben (ALPEK, B. L.TÉSITS, R. 2018, ALPEK, B. L. et al. 2018, GYŐRI F. 2011). Kirajzolódik egy vidéki nemzeti és egy nagyvárosi kozmopolita kultúra közötti törésvonal, ami több társadalmi-gazdasági mutatón keresztül is felsejlett. A foglalkoztatás szintje és a felsőfokú végzettségüek 
választókerületenként mért aránya pozitív korrelációt mutatott a balliberális pártok eredményeivel, ami számításaim szerint a pártok szavazóbázisának urbánusságából adódó hatások kiküszöbölése mellett is kimutatható volt.

A Pearson korrelációs értékek alapján megragadható egy élesebb etnikai törésvonal is, ami a Jobbik és a romák aránya között mutatható ki. Az ok-okozati viszonyról megállapítható, hogy a romák kerületenként megfigyelt aránya és a Jobbik támogatottsága közötti kapcsolat számításaim szerint egy logaritmikus regressziós modellel írható le, amelynek értéke közepes függőségi viszonyt mutatott 2014-ben, majd ez csökkent 2018-ra. Mivel ez egy feltehetően egyfajta protest választói magatartás, ezért nem is lehetett tökéletesen lineáris a kapcsolat (VIDA GY. 2014, VIDA GY. - KovÁCs Z. 2017).

A többi strukturális változóval ellentétben hazánkban a vallás kevésbé osztja meg a pártok szavazótáborát, hiszen a korrelációs értékek gyengébbek. Ennek oka, hogy a posztszocialista országok többséghez hasonlóan a kommunizmus, majd többek között a neoliberalizmus által generált fogyasztói társadalom hazánkban is gyökeresen átformálta a hittel és egyházzal kapcsolatos viszonyt, így a vallás olyan élesen nem hoz létre törésvonalat a társadalom belül, mint a lakóhely vagy az etnikai hovatartozás. Egy gyenge korrelációt azért tapasztalhatunk a katolikusok aránya és a kormánypártok között, ami vélhetően inkább a kereszténydemokrata szövetséges párthoz köthetö. Az ateisták aránya viszont egy közepes, pozitív korrelációt mutat a balliberális pártokkal és a zöldekkel, míg negatív korrelációt a Fidesz-KDNP eredményével.

A Spearman és Pearson korrelációs értékek változását bemutató pókháló diagrammról elmondható, hogy a társadalmi törésvonalak 2018-ra nagyobb különbségeket alakítottak ki, amiben döntő szerepet a lakóhely, a társadalmi státusz és az etnikai hovatartozás játszott. A 2014 és a 2018 közötti korrelációkban felismerhető nagyobb dinamika szinte csak a kormánypártokra szorítkozott. A Fidesz-KDNP korrelációjának változása 2014-ről 2018-ra és az ellenzék mutatóinak viszonylagos változatlansága arra enged következtetni, hogy a kormányzó politikai elit sikeresen osztotta meg a társadalmat a retorikai irányvonalaival, és formálta a gerrymandering torzító hatásait is. Míg az ellenzék - a taktikai szavazás emlegetése mellett - erre nem tudott válaszolni és a korábban beágyazott térbeli mintázatait örökítette tovább (VIDA GY. - KovalCSIK T. 2018).

Térbeli szempontból további jelentős folyamat, hogy a választási rendszer és az ellenzéki pártok éles versengése és elaprózódása is a kormányzó konzervatívoknak kedvezett, ezért a kormányváltást kívánók számára a taktikai szavazás lehetősége adott egyfajta esélyt. Példa már volt erre, hiszen korábban a magyar kétfordulós rendszerben az egyéni választókerületeknél volt kisebb mértékü átszavazás a második fordulóban a kisebb pártok felöl a nagyobbak felé. Majd az új választási rendszer megalkotását követően a 2014 utáni ciklusban három időközi országgyülési választáson (2015-ben) is vereséget szenvedtek a kormánypárt jelöltjei a Jobbik és az MSZP támogatóinak átszavazásai miatt, így a kétharmados többség is elveszett. Így érdemes megvizsgálni a gerrymandering jelenségét, ha a kormányzó pártokat a teljes parlamenti ellenzék szavazataival vetjük össze és a győzelem szempontjából az egyenletességet nézzük.

Ha 2018-ban a parlamentbe bejutott ellenzéki listavoksokat összeadjuk, és erre számolunk Gini-indexet a szám magasabb lesz (11,33 \%), mint a Fidesz-KDNP értéke. Ez arra utal, hogy ha éles kétpólusú verseny lenne a mandátumokért, akkor a jelenlegi kormányzó pártoknak kedvezne a gerrymandering torzító hatása, míg az ellenzék a malapportionment mellett ebböl a szempontból is versenyhátrányba kerülne. 2014-ben is hasonló érték jött ki az ellenzékre (10,77\%), azonban akkor még nem volt politikailag elképzelhető a teljes ellenzék ilyen egyértelmü összefogása.

Összegezve az előző választókerületi beosztás gerrymandering tényezőit és a pártok országos mandátumszerzési esélyeit megállapítható, hogy az új rendszerben a Fidesz-KDNP 
szavazateloszlása versenyképes, biztosítva van a hatékony mandátumszerzés a végső győzelemhez. De ez a térbeli előny csak akkor lép igazán életbe, ha az ellenzék összefog és ismét kétpólusú verseny lesz a mandátumokért. Jelen esetben a közepes és kispártok szavazatai koncentrálódtak bizonyos választókerületekben, így a gyakorlatban a gerrymandering még kedvezett is nekik. Az ellenzéki versenyben a balliberális és zöld pártoknak mandátumszerzés szempontjából kevésbé kedvezőtlen az új beosztás, míg a Jobbik viszonylag egyenletesebb voksmintázata hátrányos.

A földrajzi szemléletmód fontosságát jelzi, hogy a pártok népszerüségének térbeliségére - a szavazók mellett - a megválasztott lépték és a kerületi beosztás is hatással van. Azonban a gerrymandering vizsgálatok eredménye többször függ az elérhető adatok területi szintjeitől, holott például a folyamatok kiterjedése néhol túlmutat, néhol viszont kisebb is lehet a választókerületi határnál. Ebböl adódóan települési szinten is érdemes elemezni a gerrymandering kialakulásában szerepet játszó földrajzi tényezőket (21. ábra, 22. ábra).

21. ábra: A Fidesz-KDNP listás szavazatarányainak települési szintű Local Moran-féle autokorrelációja a 2010 és 2018-as országgyúlési választások átlaga alapján

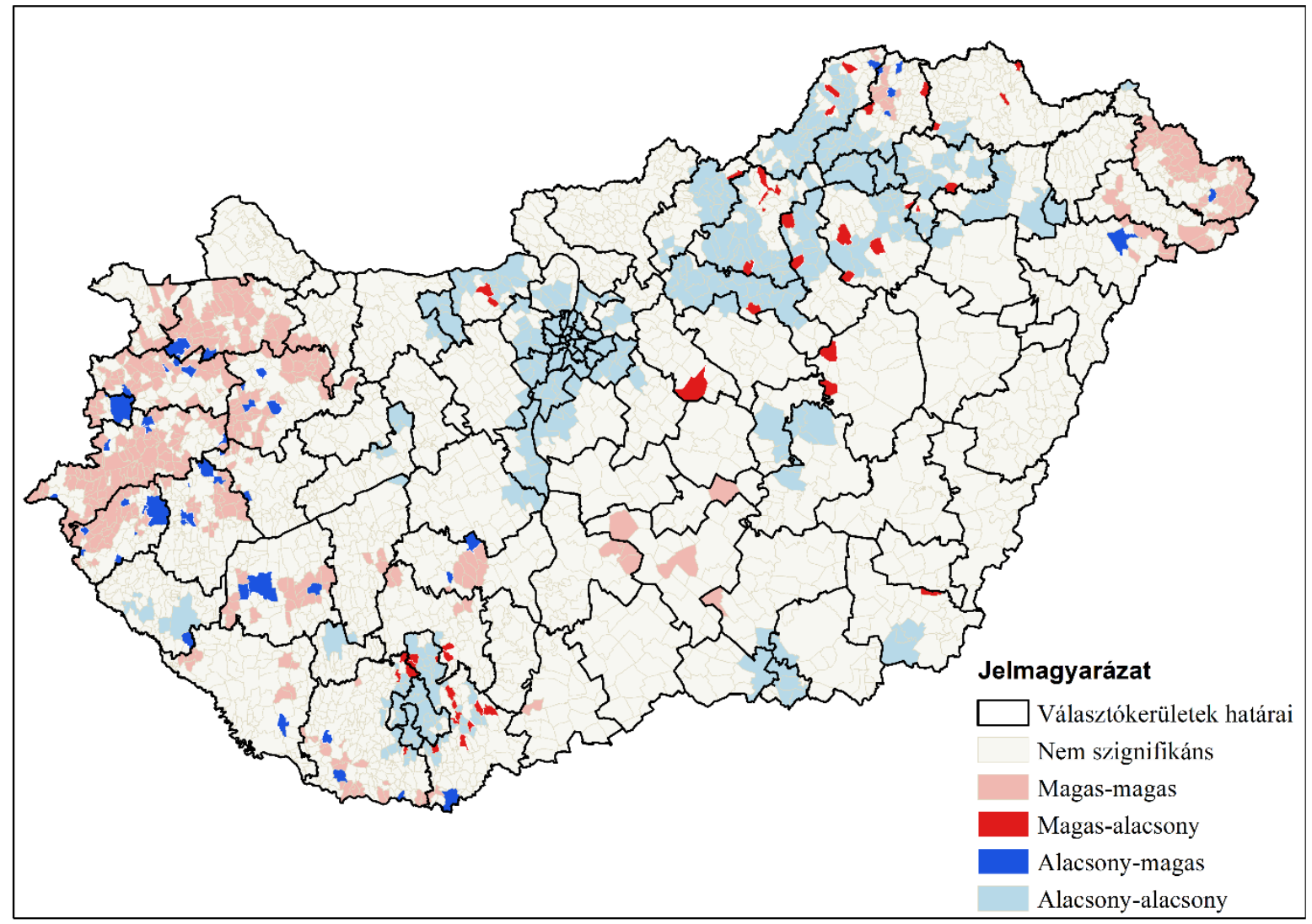

Forrás: Nemzeti Választási Iroda adatai alapján saját számítás és szerkesztés

A települési léptékű területi autokorrelációkból következtethetünk a választókerületek kialakításának hatásaira, vagyis arra, hogy a pártok szavazóbázisát mely területeken olvasztották egybe és hol választották szét. Fontos megjegyezni, hogy a Local Moran index várható értéke nulla és ha ettől szignifikánsan eltérő eredményt kapunk akkor négy lehetséges kimenetelt fejez ki a mutató. A magas-magas és az alacsony-alacsony értékek területi koncentrációja mellett a magas-alacsony vagy alacsony-magas szomszédú földrajzi mintákat is felfedezhetünk, mint kiugró értékek. A korábban használt lokális területi autokorrelációs 
mutatóhoz képest a különbség, hogy a Getis-Ord féle mutató csak a magas-magas és az alacsony-alacsony értékeket emeli ki. Tehát ebben az esetben a Local Moran index a térbeli lehatárolás szempontjából releváns, hiszen kimutatja azt, hogy a kerületi beosztásokban koncentrálódik az egyik párt szavazatai, vagy épp ellenkezőleg a kevert gerrymandering esetét fedezhetjük fel.

A Fidesz-KDNP támogatottságának települési szintü Local Moran-féle autókorrelációja rámutatott, hogy hol szerepeltek az országos eredményeikhez képest is kimagaslóan. Települési szinten a jelenlegi kormánypártok szavazóbázisa háromosztatú. Főként Győr-Moson-Sopron-, Vas és Veszprém megye rurális területei, Bács-Kiskun, Tolna és Somogy megye kisebb térségei, valamint Szabolcs-Szatmár-Bereg megye országhatár menti kisvárosai és települései tartoznak ide. Ezeken a területeken az országos átlaghoz képest is kimagaslóan szerepeltek a jelenlegi kormánypártok, miközben valamennyi ellenzéki párt átlagon alul teljesített.

Az eredményekből az is kiolvasható, hogy hol van a választókerületeken belül is nagy eltérés a Fidesz-KDNP támogatottságában. Ahol egybefüggő területen alacsony-alacsony értékeket (Budapest és agglomerációja, Észak-Magyarország, vidéki regionális központok stb.) vesz fel a kormányzó pártszövetség támogatottsága, ott van leginkább esélye az ellenzéknek mandátumot szerezni. Mindez utalhat a homogén gerrymandering kialakításának szándékára. Ezzel ellentétben tapasztalunk választókerületeken belül is éles eltéréseket, ahol magasalacsony, vagy alacsony-magas értékpárok vannak a szomszédos települések között. Ezeken a területeken a gerrymandering kevert típusai tapasztalhatók.

22. ábra: Az MSZP-Együtt-DK-PM-MLP összevont listás szavazatarányainak települési szintü Local Moran-féle autokorrelációja a 2010 és 2018-as országgyủlési választások átlaga alapján

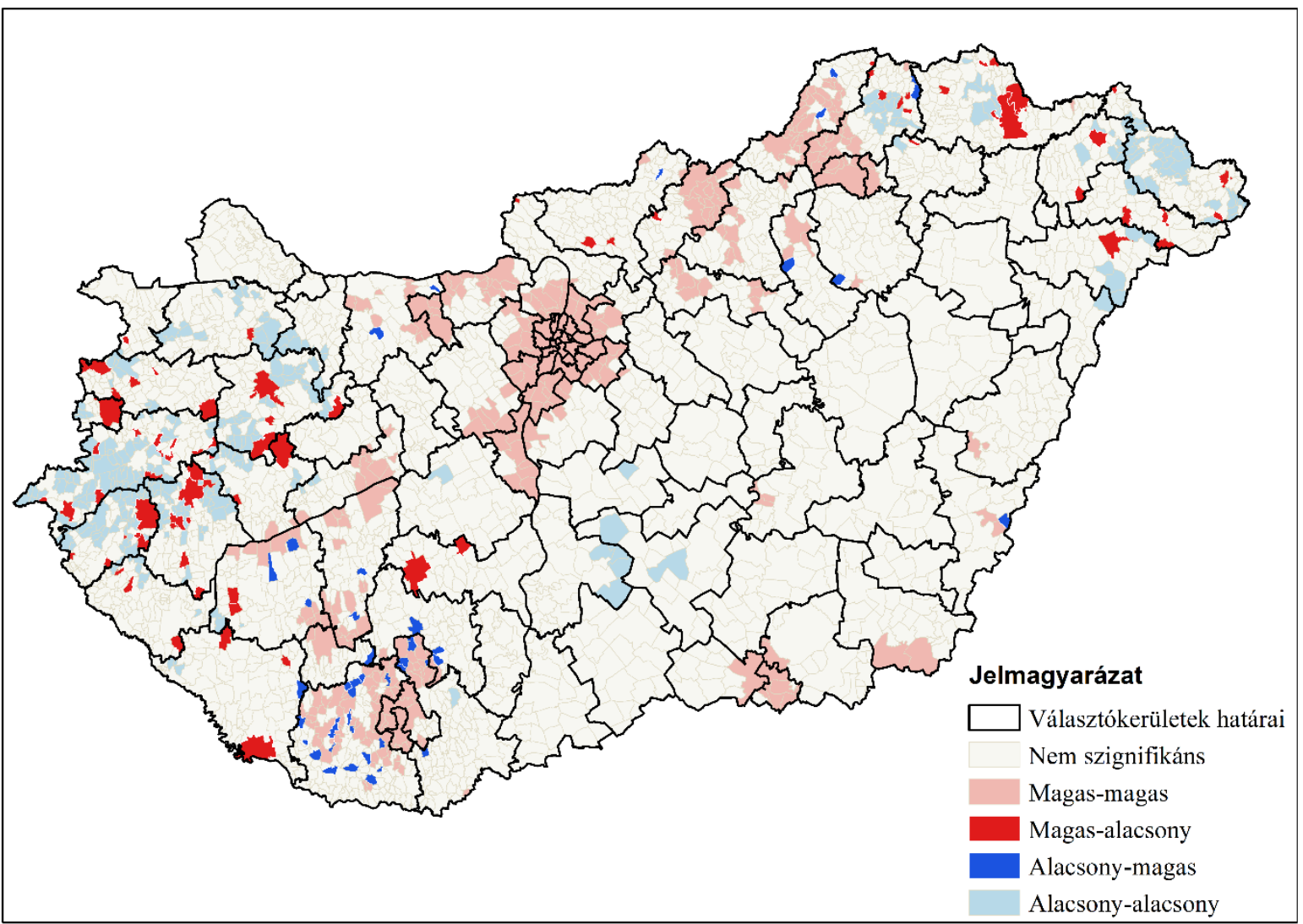

Forrás: Nemzeti Választási Iroda adatai alapján saját számítás és szerkesztés 
A jelenleg kormányzó pártszövetség mintázatával ellentétben az MSZP-Együtt-DKPM-MLP bázisát többnyire urbánus, a főváros, illetve hagyományosan baloldali nagyvárosokhoz, iparvárosokhoz köthető területek alkották (22. ábra). Ha ezt összevetjük az új választókerületi beosztással megállapítható, hogy a budapesti agglomerációban és a vidéki nagyvárosokban a hagyományosan baloldali-liberális szavazókat erőteljesen koncentrálta a választási rendszer, míg máshol a kevert, főként jobboldali pártpreferenciával rendelkező beosztás a jellemző. Az összevont listás szavazatok települési szintü elemzése alapján kevert típusú gerrymandering figyelhető meg a Nyugat-Dunántúlon és Veszprém megyében is, ahol a választókerületeken belül a nagyobb városias települések szocialista és liberálisabb bázisaihoz biztos jobboldali támogatottságú vidéki területeket kapcsoltak. Erre utal a magas-alacsony kategóriák sokasága, vagy fordítva.

Miskolc, Pécs, Szeged és Tatabánya esetében magas-magas koncentrációt tapasztalunk, viszont amíg a pécsi, miskolci és a tatabányai beosztás alapvetően homogenizálja a szavazókat, addig a szegedi példában mindkét gerrymandering alaptípus felfedezhető. Például a szegedi térségben Algyő települést a korábbi beosztáshoz képest Hódmezővásárhelyhez kapcsolták. Továbbá az egyik szegedi kerületböl biztos balliberális fellegvár lett, míg a kettes kevert típusú, ahol a jobboldal nyert. Ha összehasonlítjuk a konzervatív és balliberális oldal térbeli mintázatát kirajzolódnak a város-vidék ellentétek választókerületeken belül is. Rendszerint a kevésbé kormánypárti központi várost ellensúlyozza a vonzáskörzet és a területhez kapcsolt további vidéki települések. Ez a folyamat különösen a Dunántúlon volt megfigyelhetö. A Jobbik és az LMP támogatottságának térbeli elemzéséből megállapítható (23. ábra, 24. ábra), hogy olyan kerületeken belüli szignifikáns eltérések nem rajzolódtak ki, mint a Fidesz-KDNP és a balliberális oldalhoz tartozó pártok esetében. Mindkét párt esetében inkább homogén tömbök találhatók.

23. ábra: A Jobbik listás szavazatarányainak települési szintű Local Moran-féle autokorrelációja a 2010 és 2018-as országgyủlési választások átlaga alapján

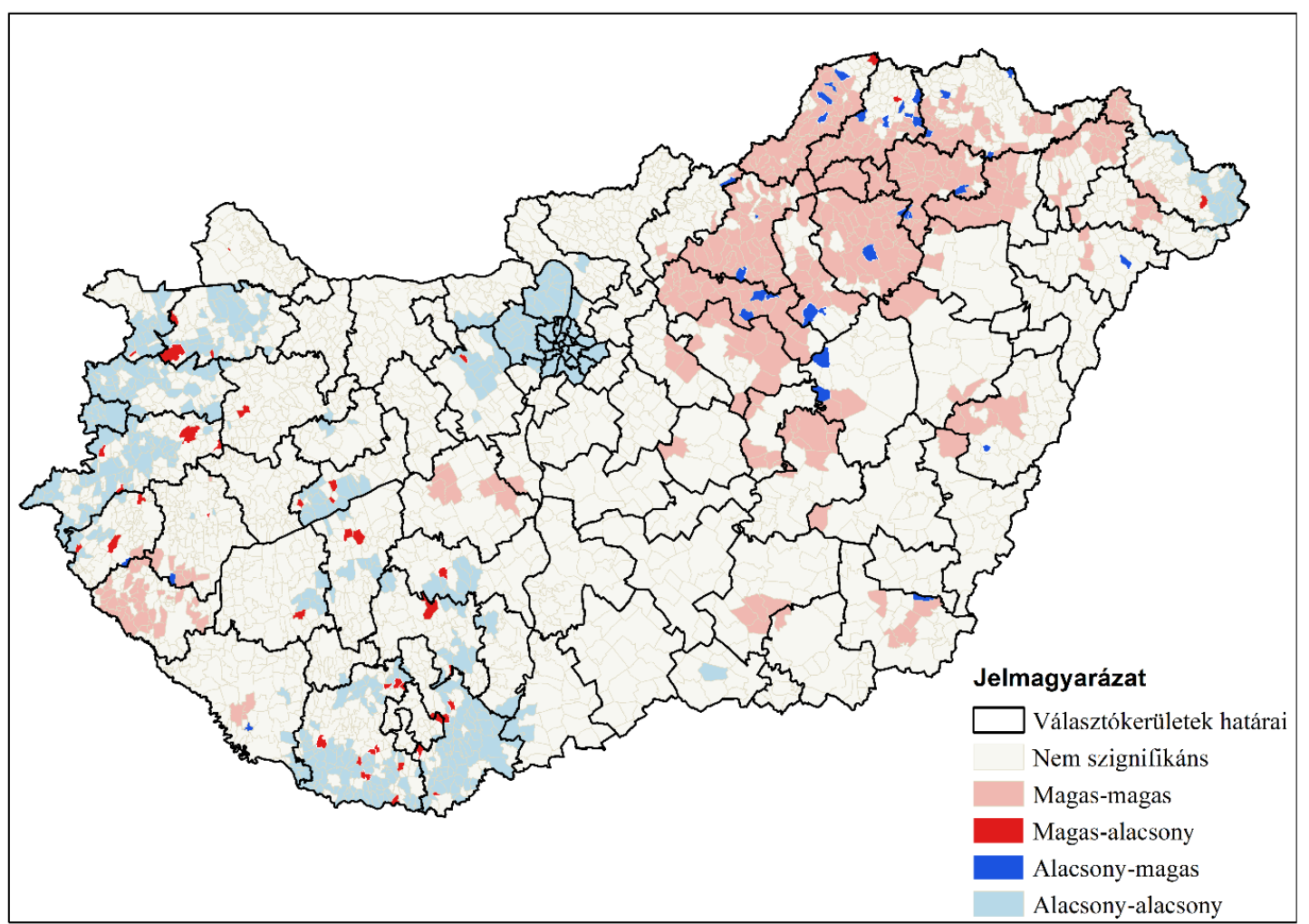

Forrás: Nemzeti Választási Iroda adatai alapján saját számítás és szerkesztés 
A Jobbik egy nagyon jól körülhatárolható területen népszerü, néhány kisebb lélekszámú települést leszámítva Borsod-Abaúj-Zemplén, Heves, Jász-Nagykun-Szolnok és SzabolcsSzatmár-Bereg megye választókerületeiben homogén magas-magas támogatottsággal rendelkezett. A fővárosban és agglomerációjában, valamint Baranya, Győr-Moson-Sopron és Vas megyében pedig a párt többnyire alacsony-alacsony területi autokorrelációt mutatott. A Jobbik Magyarországért Mozgalom a Dunántúlon két területet leszámítva gyengén szerepelt 2010 és 2018 között. A két kiugró terület a Dunaújváros és Sárbogárd közötti térség, valamint Nagykanizsa és környéke. Összességében megállapítható, hogy a Jobbik esetében a homogenizált magas-magas területeken szerepelt sikeresen és képviselői helyeket is itt volt esélye nyerni.

Az LMP a Jobbikkal ellentétben erősen koncentrálódott települési szinten is az urbánusabb térségekben, föként a gazdaságilag kifejezetten versenyképesebb településeken (VIDA, GY. - DUDÁS, G. 2017). Magas és magas területi autokorrelációt mutatott fóként Dunántúlon és a nagyvárosokban. Ebből adódóan Budapest mellett Pécs, Sopron, Székesfehérvár, Szombathely és Tatabánya választókerületeiben építhettek ki bázist. Ezzel ellentétben alacsony és alacsony értékkel rendelkezett Borsod-Abaúj-Zemplén és SzabolcsSzatmár-Bereg megye választókerületeiben. Itt 2010 és 2018 között igazából sohasem volt parlamenti bejutási küszöb felett a párt.

24. ábra: Az LMP listás szavazatarányainak települési szintü Local Moran-féle autokorrelációja a 2010 és 2018-as országgyúlési választások átlaga alapján

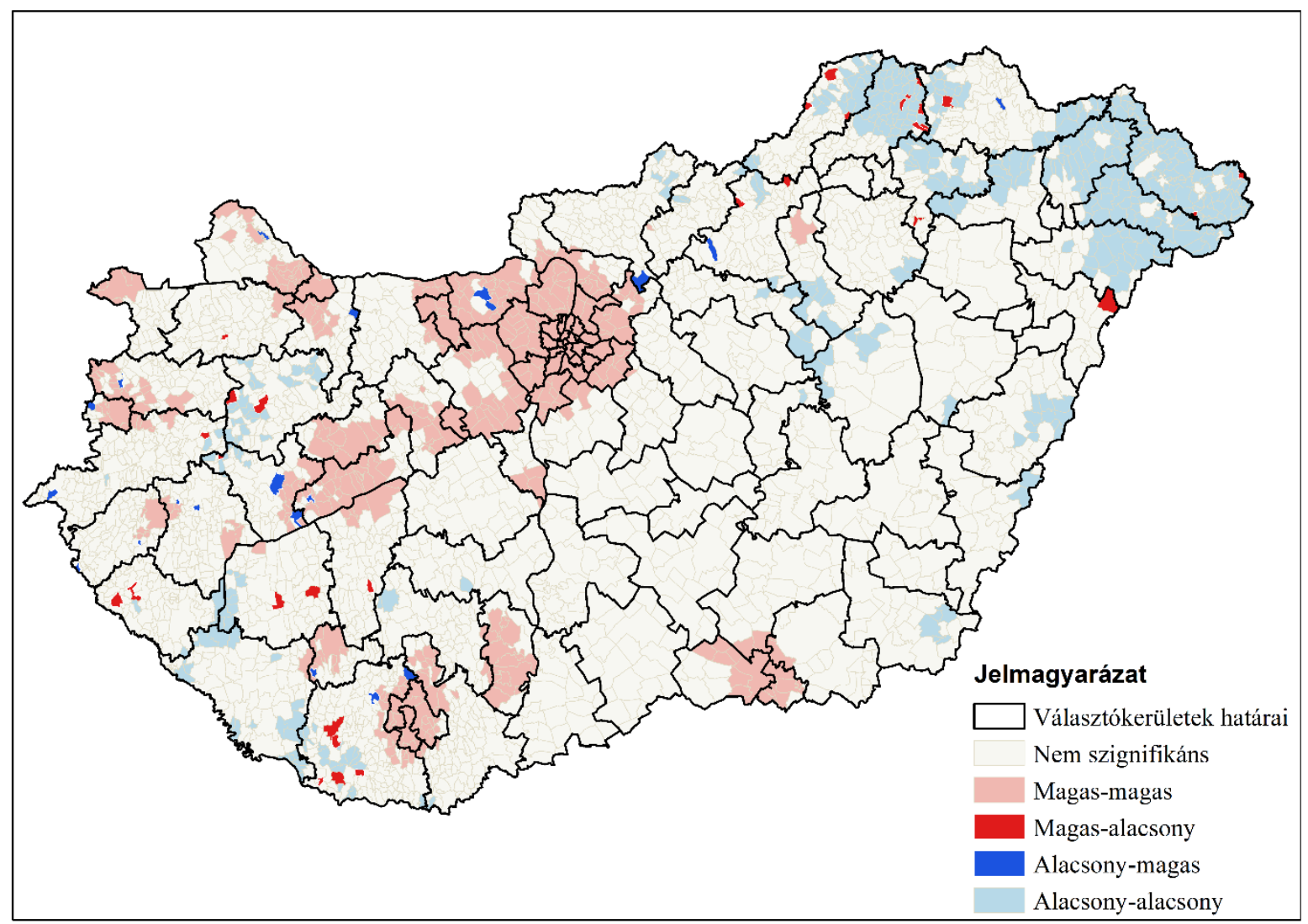

Forrás: Nemzeti Választási Iroda adatai alapján saját számítás és szerkesztés 
Összegezve: a földrajzi torzulásokat befolyásoló tényezők összetettek, emellett térben és időben folyamatosan változnak, de a hagyományos társadalmi törésvonalak párttszimpátiát és gerrymanderinget strukturáló hatása is kimutatható hazánkban. A baloldali összefogás és az LMP támogatói is döntően urbánus területekre koncentrálódtak, míg a Fidesz-KDNP és a Jobbik a vidéki kisvárosok és falvak választókerületeiben szerepelt átlagon felül. Azonban 2018-ra a kormánypártok támogatottságának viszonylagos átrendeződése, a balliberális szavazók urbánus koncentrációja és a Jobbik szavazóinak térbeli keveredése is fellelhetô az új beosztásban.

Az eltérő módszerek együttes használata azt jelzi, hogy a mutatók korrelációjával és regressziójával szemben a területi statisztikai elemzések eredményei az általános tendenciával ellentétes térbeli mintázatot is a felszínre hoztak. Ennek oka a választói viselkedést meghatározó, összetett tényezőkben keresendő. Egyebek között ilyen lehet a térségek történeti és társadalmi fejlődése, a helyi elit befolyása, az új és régi lakók közötti konfliktusok megnyilvánulásai. Ezért a témakör vizsgálatában a földrajznak kiemelt szerepe van, és célszerü az elemzéseket kiterjeszteni úgy, hogy újabb politikai és térbeli tényezőket (pl. kampánystratégiák térbelisége, online kommunikációs hálózatok értelmezése stb.) is beépítünk az földrajzi torzulások elemzéseibe. Így a kutatás a nagyobb települések belső választásföldrajzi feltárásával további tudományos hozadékkal is bírhat. 


\section{Összegzés}

A bevezetésben felvázolt gondolatok kapcsán doktori disszertációm célkitüzése kettős volt. Egyrészt, hogy a nemzetközi szakirodalom alapján minél pontosabban leírjam a a magyar választási rendszerben is megfigyelhető földrajzi torzulások sokrétüségét, részletezve a résztényezők közötti dinamikus összefüggéseket. Másrészt, hogy a 2002 és 2018 között lezajlott magyar országgyülési választások alapján kimutassam a földrajzi torzulások mértékét hazánkban és az erre ható mögöttes demográfiai és társadalmi folyamatokra is rávilágítsak.

Doktori disszertációmban elsősorban a magyar választási földrajzban eddig kevésbé vizsgált elméleti koncepciók, összefüggések bemutatását és az angolszász megközelítés adaptálását végeztem el. Ennek érdekében feldolgoztam a választási földrajz hazai és nemzetközi szakirodalmát. A vonatkozó szakirodalom feldolgozását a választási földrajz tudományerületének fejlödési pályájának bemutatásával kezdtem, hiszen így meg tudtam határozni a mandátumkiosztás térbeli vonatkozásainak tágabb tudományos kereteit. Ezután a választási rendszerek főbb típusait és a politológiában használatos általános aránytalanság fogalmát fejtettem ki, hiszen a tudományterületek mást értenek e meghatározás alatt. Szükséges volt hangsúlyozni, hogy a választási rendszerek általános aránytalanságánál a térbeli tényezők szerepe is nagyon fontos.

A választási rendszerek általános tulajdonságai után a mandátumkiosztás földrajzi vonatkozásainak elméleti keretét jártam körbe. Ehhez a tématerület angolszász eredményeit dolgoztam fel. Elsőként szükséges volt egy átfogó fogalmat (electoral bias) is adaptálni és magyar folyamatokra értelmezni. Így a szakirodalom alapján meghatároztam a földrajzi torzulás fogalmát, ami magában foglalja mindazon választással kapcsolatos térbeli tényezőket, ami a mandátumkiosztásban egyenlőtlen politikai reprezentációt hoz létre. Ebbe a keretbe az angolszász modellben értelmezett résztényezőket kapcsoltam és a magyar viszonyokra értelmeztem. Így a területi aránytalanságot a választókerületek nagyobb közigazgatási határokon (esetünkben megyehatárok) belüli és kívüli méretbeli különbségeivel, a reactive malapportionment hatását a választási részvétel és az egyéb mandátumkiosztásba nem kerülö voksok tényezőivel, végül a gerrymandering tényezőjét a pártok támogatottságának térbeli eloszlásával hoztam összefüggésbe.

Az értelmezéseket kritikai és posztstrukturalista nézőpontokkal egészítettem ki. Ezen koncepciók ütköztetése bizonyíték arra, hogy a választókerületek igazságos kialakításának kérdésköre napjainkban egyre fontosabbá válik, amivel célszerü foglalkozni. A nyugati szakirodalmak felvázolása után a dolgozat bemutatta a posztszocialista térségre jellemzö választási földrajzi torzulásokat. A rendszerváltozás óta végbement politikai és társadalmi folyamatokról a posztszocialista térségben már több publikáció született, ami a térség imént említett kérdésköreit vizsgálta, ennek ellenére ez a témakör még kevésbé megkutatott.

Az elméleti keretek ismertetése után a dolgozat központi kérdése arra irányult, hogy: Milyen földrajzi torzulások jellemezték a magyar választási rendszert 2002 és 2018 között? Ennek a kérdésnek a részletes megválaszolásához több részkérdést igyekeztem körbejárni.

Első elméleti részkérdésem arra irányult, hogy milyen elméleti összefüggések vannak a malapportionment, a gerrymandering és a reactive malapportionment között? A nemzetközi és hazai elméleti háttér bemutatását követően megfogalmaztam, hogy a földrajzi hatótényezők statikus ok-okozati értelmezése helyett a résztényezők közötti interakciók azok, amik igazán befolyásolják a földrajzi torzulások valódi természetét. Ebből adódóan a nemzetközi szakirodalmak szintetizálása alapján Magyarországra vonatkozóan egy általános elméleti modellt alkottam. Rendszereztem, hogy a gerrymandering, malapportionment és a reactive 
malapportionment kialakulására és interakcióira a döntéshozók mellett milyen föbb demográfiai és társadalmi tényezők hatnak.

Az elméleti modellben szükséges külön értelmezni az elgondolt, vagy látens földrajzi torzulásokat, ami az elemzés kereteit adják. Ebböl adódóan az elgondolt földrajzi torzulásokban a malapportionment azon belül a választásra jogosultak számának területi különbségei, továbbá a nagyobb közigazgatási határokon kialakult eltérések adják az torzulás alapját. Ha ezt összevetem a gerrymanderinggel, vagyis a pártok támogatottságának térbeli egyenlőtlenségeivel, akkor kimutatható egyfajta elgondolt földrajzi torzulás a választási rendszerekben. Gyakorlati szempontból érdemes bevezetni a megvalósult földrajzi torzulás fogalmát is, ami már döntően a reactive malapportionment és a gerrymandering közötti dinamikus interakciókon alapszik. Itt kapcsolódik be a megvalósult földrajzi torzulás kialakításába maga a választó. Fontos kiemelni, hogy a gerrymandering és reactive malapportionment között kölcsönös és folyamatos függési viszony tapasztalható. Нa a modellben bármelyik tényezőben változás alakul ki a választásokon az azonnal automatikusan hat a többire is, így a földrajzi torzulásokon belül mindkét folyamat hatóerejére is.

Az elméleti kérdés megválaszolását követően a magyar választási törvény részletes térbeli vonatkozásainak, valamint növekvő általános aránytalanságainak bemutatását követően a dolgozat elsőként arra a részkérdésre is választ keresett, hogy választókerületi szinten 2002 után hogyan alakult a parlamentbe bejutott pártok választási földrajzi térszerkezete. Magyarország választókerületeiből a 2002-es és a 2006-os eredmények alapján négy, míg a 2010-es, a 2014-es és a 2018-as választásokra támaszkodva öt klasztert lehetett létrehozni, melyek között számottevő földrajzi különbségeket és átrendeződéseket lehetett kimutatni.

A 2002-es parlamenti választások eredményei átrajzolták a kilencvenes évek választási földrajzi sajátosságait és választókerületi szinten már ekkor kialakult egy éles térbeli törésvonal a jobboldali és baloldali területek között. Az országos átlaghoz hasonlatos kerületek magas száma ugyanakkor arra engedett következtetni, hogy 2002-ben még nem voltak olyan jelentős eltérések, mint később. A 2006-os parlamenti választások eredményei megerősítették és kiélezték a korábbi térszerkezetet és a korábbi állapothoz képest az országos átlaghoz hasonlatos kerületek száma jelentősen csökkent. 2006-hoz képest 2010-ben a választói magatartás markáns térbeli átrendeződése volt tapasztalható. A Fidesz-KDNP győzelme mellett a baloldali szavazóbázist jelentő vidéki válságtérségekben megerősödött a Jobbik, miközben az MSZP visszaszorult. Míg a Jobbik döntően vidéki, gazdaságilag hátrányos helyzetü területeken vált sikeressé, addig az LMP a vidéki nagyvárosokban és a fővárosban szerepelt kiugróan.

A 2014-es választások földrajzi tapasztalatait összegezve megállapítható, hogy egyrészt az új választókerületi lehatárolás formálta a pártok térbeli eloszlását, így a 2010-hez hasonló felállás ellenére egy új térszerkezet alakult ki. Másrészt a politikailag instabil Észak-KeletMagyarországon (pl. kazincbarcikai, kisvárdai, ózdi választókerület) érezhető volt a Jobbik tartós előretörése, míg a korábbi biztos szocialista térségekből a baloldali és liberális összefogásnak csak a nagyvárosi kerületekben sikerült visszaszereznie korábban elvesztett támogatottságát. A fóváros mellett kifejezetten a nagyvárosi kompakt kerületekben (pl. a tatabányai, mindkét pécsi és a szegedi 1-es) maradt erős a baloldali összefogás.

Így a 2014-es és 2018-as országgyülési választások eredményei alapján a választókerületeket jellemezhetjük egyfajta állandósággal, hiszen a Fidesz-KDNP politikai dominanciája mellett a választási földrajzi különbségek szerepe leértékelődött. Azonban dinamikus átrendeződéseket is tapasztalhattunk, amihez szorosan hozzátartozik a gazdasági és társadalmi folyamatok által kialakított törésvonalak erősödése, ami részben meghatározta a pártidentitást. A nemzetközi folyamatokhoz hasonlóan hazánkban is jelentős a város-vidék ellentét, ami jobb és balliberális oldal mentén tematizálta a politikai táborokat, de emellett az 
iskolázottság, a foglalkoztatottság és a gazdasági helyzet is szerepet játszott. A választói magatartás imént felsorolt tényezői 2018-ra erősödtek, azonban ezek értelmezésében a parciális hatások is fontosak voltak. A közeljövőben a választókerületek kevesebb mint felében lehet élesebb verseny a parlamenti mandátumokért. Az urbanizált baloldali fellegvárakban kétpólusú küzdelem várható, míg a Jobbik fellegvárai a pártszakadás miatt választási földrajzi szempontból instabilakká válhatnak.

Ezután a következő részkérdés volt, hogy az ezredforduló után a magyar választókeriületi lehatárolásokban mekkora volt a malapportionment? Az eredményekből megállapítható, hogy 1990 és 2010 között a fővárosi agglomerációban és a többi nagyvárosi térség választókerületeiben a szuburbanizáció és a belső migráció folyamata jelentősen megemelte a választásra jogosultak számát, míg a periférikus területek kiürültek. Ebböl adódóan szükséges volt új választókerületeket rajzolni úgy, hogy a határmeghúzásnál az is komoly problémát jelentett, hogy a megyék határát egy választókerület sem keresztezhette. Az új választókerületi beosztás nyomán egyértelmüen csökkentek az eltérések, hiszen a 2011-es adatok szerint a legnagyobb választókerületben a választásra jogosultak száma csak másfélszer volt nagyobb a legkisebbhez képest, a korábbi 2,79-es értékkel szemben. Ez a 2014-es választásokra mérséklődött, hiszen ekkor a maximum és minimum hányadosa 1,39 volt, majd 2018-ban ismert átlépte a másfélszeres $(1,52)$ különbséget. Az országos átlagtól való differencia is mérsékeltebbé vált a kerületek többségénél, ami arra utal, hogy részben sikerült orvosolni az eltéréseket.

Az új lehatárolás nem vette kellöképpen figyelembe a demográfiai folyamatokat, így a rendszer magában hordozta a probléma gyors újratermelődését. A rurális, periférikusabb térségekben a túl kicsire szabott egyéni választókerületek, míg föként a foováros és agglomerációjában, valamint a vidéki nagyvárosi területeken a túlméretezés okozott problémát. A demográfiai folyamatok még rövid időintervallumon belül is átírták a feltételeket, hiszen a statisztikai adatok a lakóhelyi mobilitás felgyorsulását és a választási földrajzi kihívás újratermelését mutatták. A főváros agglomerációjában és néhány vidéki nagyvárosi térségben tovább folytatódott a választópolgárok számának és arányának dinamikus növekedése, így 2018-ra az átlagtól való 15\%-os differencia-küszöböt több választókerület is átlépte, sőt néhány már a jogszabályban meghatározott szigorú 20\%-os határt is meghaladta. A közelmúlt demográfiai tendenciáit figyelembe véve ez a helyzet a jövőben tovább fog súlyosbodni, így a közeljövőben újabb térfelosztásra lesz szükség.

Ezen túlmenően megállapítható, hogy míg 2002 és 2010 között a korábbi rendszerben a választásra jogosultak választókerületi szintü területi eloszlásának nem volt szignifikáns összefüggése egyik párt listájával sem, addig a 2014-es és a 2018-as eredmények tükrében már szignifikáns gyenge negatív korreláció volt a Fidesz-KDNP listájával. Tehát ahol a FideszKDNP kimagaslóan szerepelt, ott többnyire kisebbek voltak a kerületek, és fordítva. Alapvetően az új beosztás területi aránytalanság tényezője a többi pártot nem hozta helyzetbe, de nem is gátolta az érvényesülésben.

Mivel a kezdeti peremfeltételeket a választási részvétel egyenlőtlenségei és a mandátumkiosztásba be nem kerülö voksok földrajzi eltérései módosítják ezért a következő elemzésem annak megválaszolására irányult, hogy hogyan módosították a malapportionment hatótényezőjét a választási részvétel és a mandátumszámításba be nem kerülö voksok változó területi különbségei? Ha elemezzük a parciális összefüggéseket, valamint a részvételi különbségekkel és az érvénytelen, illetve a mandátumok kiosztásába be nem kerülő voksokkal is súlyozunk, akkor a kirajzolt trend erősödött. A két nagy párt esetében 2002 és 2010 között nem volt szignifikáns korreláció, így sem a Fideszt, sem az MSZP-t nem hozta helyzetbe ez a tényező. A többi pártnál gyenge pozitív és negatív korrelációkat tapasztaltam, míg a Jobbiknak 2010-ben kedvezett a területi egyenlőtlenség, addig az SZDSZ, MDF és LMP hátrányba került. 
Az utóbbi pártok esetében ennek egyik fő oka a pártok akkori támogatottságának jellemzően városias jellege.

A fentiekben leírt jelenség az új választókerületekben megváltozott, és 2014-ben és 2018ban is szignifikánsabb korrelációk voltak tapasztalhatók. Ha a jelenleg hatályos választókerületi beosztás eltéréseinél a részvételt is elemezzük, akkor már jelentősebb reactive malapportionment tapasztalható az új választási rendszerben. A Fidesz-KDNP esetében felerősödtek a kedvező hatások, hiszen jól szerepeltek olyan kerületekben, ahol kevesebb szavazó még alacsonyabb aktivitást produkált, ellentétben az urbanizált területekkel. Másrészt az is kirajzolódott a súlyozást követően, hogy eltünt a rendszer semleges hatása az ellenzéki pártokra nézve és a súlyozott eltérések már szignifikánsan befolyásolták a szereplésüket. A Jobbikot kismértékben pozitívan támogatta az új térfelosztásban rejlö térbeliség, míg a balliberális oldalhoz kapcsolható pártokat hátrányosan érintette az újabb beosztás. Igaz a hátrány mértéke csökkent 2014-röl 2018-ra, aminek oka volt, hogy az urbanizált területeken a magasabb részvétel nagyobb mandátumkiosztásba nem kerülő vokshalmazzal párosult.

Tehát a szavazók aktív szerepvállalása felerősítette a magyar rendszerben a területi aránytalanság hatását. Ez a fajta földrajzi torzulás a jobboldali pártokat (föként a FideszKDNP) hozta kedvező helyzetbe, míg a baloldali, liberális és zöld pártokat szignifikánsan és jelentősebben gyengítette. Ennek oka, hogy amíg a MSZP-PM és DK, Együtt pártok és az új politikai formációk támogatottságuk jelentős részét koncentráltan a nagyvárosi kerületekben szerezték, addig vidéken egyértelmü volt a Fidesz-KDNP előnye, a Jobbikot leszámítva a többi ellenzéki párt itt súlytalanná vált.

A politikai pártok térbeli beágyazottságának viszonylagos stabilitásából le lehet vezetni azt, hogy a választási rendszerben mekkora a gerrymandering hatása. Ebből adódóan a gerrymandering mandátumkiosztásban betöltött szerepét próbáltam meghatározni annak a kérdésnek a megválaszolásával, hogy hogyan alakult az ezredfordulót követöen a magyar választókerületi beosztásokban a gerrymandering. Az értekezésben kifejtett statisztikai elemzésekből következik, hogy a versengő nagypártoknál kedvező az egyenletes eloszlás, míg a közepes-, és kispártoknak a koncentrált támogatottság hozhat potenciálisan nagyobb politikai reprezentációt. Ebből következik, hogy 2002-ben és 2006-ban az MSZP-t és az SZDSZ-t hozta kedvezőbb pozícióba a rendszer, míg a Fidesz-MDF, majd a Fidesz-KDNP és az MDF versenyhátrányt szenvedett. 2010-re fordult a kocka és a választási rendszer változatlansága mellett a Fidesz-KDNP egyértelmü haszonélvezője lett a gerrymandering hatásának, míg az MSZP középpárttá zsugorodása révén mérsékelt hátrányt szenvedett. A Jobbik és az LMP országos eredményeiből szavazói térbeli koncentráltsága volt megfigyelhető.

Az új választási rendszerben 2014-re a gerrymandering formálásában már erőteljesen közrejátszott az átszabott beosztás is. A 2010-es országos eredményhez képest az ellenzék javítani tudott, azonban szavazói a korábbinál is nagyobb koncentráltságot mutattak. Ez az akkori politikai környezetben előny volt, hiszen így szereztek mandátumot. Azonban egy kiélezett versenyben a balliberális ellenzéki pártok még rosszabb helyzetböl indultak, mint 2010-ben, míg a Fidesz-KDNP hatékonysága a legjobb volt.

2018-ra az országos pártpolitika átrendeződése és az ellenzéki átszavazások ellenére érdemi változás nem következett be ebben a folyamatban. A taktikai szavazás a közepes-, és kispártok szempontjából a 2018-as választás gyakorlatában ismét elöny volt. Az LMP, de főként az MSZP-PM és a DK szavazótáborának erőteljes koncentrációja és ebből adódó alkupozíciója az, ami miatt több egyéni mandátumot tudtak szerezni, ami a Jobbik esetében az egyenletesebb támogatói eloszlás miatt nem valósult meg. A taktikai szavazás az angolszász országokhoz hasonlatosan egyfajta sikeres út lehet az ellenzék számára. Így, ha az ellenzék eredményét összegezve vizsgáltam, akkor a korábbi koncentráltságból fakadó előny máris hátránnyá alakult, hiszen kiélezett versenyben a Fidesz-KDNP szavazateloszlása hatékonyabb 
a jelenlegi választókerületi beosztásban.

Az előző gondolatmenetet folytatva a területi autokorrelációs elemzésekből kirajzolódnak a választókerületeken belüli települési eltérések. Meghatározhatók a gerrymandering koncentrált és kevert alaptípusai. Kevert típusú gerrymandering figyelhető meg a NyugatDunántúlon és Veszprém megyében, ahol a választókerületeken belül a nagyobb városias települések szocialista és liberális bázisaihoz átlagon felüli jobboldali támogatottságú vidéki területeket kapcsoltak. Erre utalnak a magas-alacsony területi autokorrelációs kategóriák mintázatai. Ezzel ellentétben Miskolc, Pécs, Szeged és Tatabánya esetében magas-magas koncentrációt tapasztaltam, ami alapvetően a homogenizált lehatárolásra utal. A Jobbik és az LMP viszonylatában ilyen markáns választókerületi eltéréseket nem tapasztaltam.

A doktori disszertációm alapján gyakorlati szempontból kijelenthető, hogy célszerü lenne egy új kerületi térbeosztást létrehozni. Megállapítható, hogy a témakör bonyolultsága miatt egy általam megrajzolt alternatív országgyülési választókerületi térfelosztás kialakítása meghaladná a disszertáció terjedelmi kereteit. Azonban a választókerületek kialakításának hazai szempontjaihoz a korábbi és jelenleg hatályos beosztás elemzése mellett megfogalmaztam azokat a gyakorlati javaslatokat, amit a jövőben figyelembe kellene venni a döntéshozónak, ha igazságosabb és hatékonyabb mandátumkiosztást szeretnének. Ezek a javaslatok az alábbiakban foglalhatók össze:

- Magyarország esetében a választókerületek kialakításánál szakmai szempontból a legfontosabb az egy ember egy szavazat elv érvényesítése. Ezt követné az az elv, hogy a választókerületeknek egybefüggő területeknek kell lenniük.

- Nemzetközi tapasztalatok alapján a választókerületek megrajzolásánál az országos átlagtól való eltérés mértékét csökkenteni kell 15-20 százalékról 10-15 százalékra.

- Minden magyarországi népszámlálás után érdemes felülvizsgálni az aktuális felosztást és az iménti elv sérülése esetében szükséges módosítani azt.

- Az előzőből következik, hogy a választási törvény és a főbb elvek meghatározása maradjon kétharmados, azonban a konkrét kerületek felosztását egyszerü parlamenti többséggel lehessen módosítani.

- Ezért a nemzetközi gyakorlathoz hasonlatosan térfelosztási szakmai bizottságot szükséges felállítani szakértőkkel, akik megfogalmazzák az aktuális tervezési gyakorlatokat. Ezzel a gerrymandering tényezőjét is ellenőrizni lehet.

- A választókerületek megrajzolásánál figyelembe kell venni a mögöttes demográfiai folyamatokat (fertilitás, mortalitás, belső és külső migráció, szuburbanizáció stb.), hiszen így időtállóbb beosztások születhetnek.

- Figyelembe kell venni a választási részvétel szerepét és úgy kell beépíteni a felosztási modellbe, hogy a magasabb aktivitással rendelkező területeken legyen az átlagosnál kevesebb választásra jogosulttal rendelkező kerület és fordítva. Így jobban érvényesülhet az egy szavazó egy szavazat elve.

- A jövőben kezelni kell a külföldön tartózkodó állampolgárok szavazásának technikai lebonyolítását (pl. elektronikus szavazás ügyfélkapun keresztül stb.), hiszen ez is hat a mandátumok kiosztására.

Fontos kiemelni azt is, hogy a társadalom térszerveződésének és politikai véleményformálásának összetettségéből adódóan a választókerületi határok megrajzolásával a döntéshozó csak részben tud hatni a választási manipuláció természetére. A gazdasági, politikai és társadalmi folyamatok nem feltétlen vannak lineáris összefüggésben a választási eredményekkel. Ezért a gerrymandering elemzése mellett, az értékeket módosító tényezők (pl. 
lakótelepeknél a szavazók valós térbeli koncentrációja miatt nehéz választókerületeket létrehozni) kimutatása a későbbiekben egy külön tudományos kutatást is megér. Mindemellett a választópolgárok a gerrymandering tényezőjére jelentős hatást gyakorolnak aktivitásukkal, amit a választási magatartás mögött meghúzódó közvetett tényezők, például a szomszédsági hatás, a társadalmi törésvonalak, a társadalmi kapcsolathálózatok és az online és offline kommunikáció hatásai is befolyásolnak.

A témakörnek további elméleti és módszertani kutatási lehetőségei vannak. Az egy ember egy szavazat elvének térspecifikus elméleti vizsgálatánál lényeges lehet nemzetközi példákkal választási rendszertől függően további tényezők (pl. preferenciális szavazás, kampánystratégiák) mandátumkiosztást torzító hatásának felmérése. Ezen tényezők kifejtése és különböző mintaterületeken történő kimutatása pontosíthatná a torzulás sokszínüségét. Emellett a földrajzi torzulások kutatása a nagyobb települések belső választásföldrajzi vizsgálatánál is komoly tudományos hozadékkal bírhat. Így az elmélet kiterjesztése mellett a módszertani irányt a földrajzi hatások számításának és térképezésének a finomítása jelenthetné szavazóköri adatok bevonásával és modellezésével, ami segíthetne az elemzések pontosításában a nagyvárosi terekben. Továbbá a disszertációban felvázolt földrajzi torzulások összetett dinamikus összefüggéseinek vizsgálata megfelelő adaptálást követően kiterjeszthető lenne a környező posztszocialista országok választási rendszerére is.

Magyarország esetében komoly elméleti kérdéseket vet fel a földrajzi torzulások résztényezőit pontosan kifejező magyar fogalmak megalkotása. Ez a tényezők összetettsége miatt nagyon nehéz és meglátásom szerint megér a magyarországi geográfiában egy tágabb tudományos diskurzust. Mindemellett mérési szempontból hazánkban a vizsgálat megismétlése későbbi időpontokban (a 2022-es, 2026-os országgyülési választásokat követően) lehetőséget nyújtana a torzulások időbeli változásainak további követésére, így a hosszabb távú választási földrajzi folyamatok felvázolására. Szükségszerü az elemzések hiányosságait, módszertani korlátait is felismerni, továbbá a későbbiekben finomítani is azokat. Mivel a jelenlegi beosztásban a választókerületek méretbeli eltérései újból sértik a törvényben meghatározott kereteket, így bármikor áttervezhetik a választókerületi beosztást. Ebben az esetben ismét vizsgálhatóvá válik a döntéshozók ráhatása a rendszerre. Ezen a ponton a disszertáció gyakorlati szempontból is támpontokat szolgáltathat, hiszen, ha a választókerületek lehatárolásánál figyelembe vesszük a mögöttes demográfiai és társadalmi folyamatokat, akkor időtállóbb és igazságosabb beosztást hozhatnak létre a döntéshozók. 


\section{Summary}

In democracies it is an important issue how the different types of electoral systems convert the votes into seats. The effects of geography on political representation is of high importance especially in those countries where the votes are cast within some territorial framework which is especially the case in majority based or mixed electoral systems. The relevance of this $\mathrm{Ph}$.D. dissertation is that, there was shown a great discrepancy in the number of electors in constituencies, after the change of regime in Hungary, when a mixed electoral system was established. This demographic process has continued to grow and will need to be adjusted in the electoral system. The Act on the election of the Members of the Parliament (Act CCIII) was enacted in 2011, while the Act on the electoral procedure (Act XXXVI) was codified in 2013. The new law transformed the framework of the elections and reduced the number of MPs from 386 to 199. The transformation included a descrease in the number of individual constituencies from 176 to 106 and a rearrangement of the borders. In the new system, two parliamentary elections have already been conducted and consequently, the impact of geographical factors on the distribution of mandates has become verifiable concerning the previous and the current Hungarian electoral system.

Because the alteration of boundaries of constituencies has a significant impact on results, theoretical and practical questions about the spatial effects of electoral systems have long been a topic of political geography. There is a wide international literature on geographical bias in electoral systems, but the analysis of majority systems and Anglo-Saxon dominance is striking. After the change of regime several electoral geographic studies were published, which revealed continuity of participation and party supporters and the underlying factors affecting them. However, the analysis of geographical bias in the electoral system has not yet been the focus of researches. Besides, it is important from a practical point of view that, when delimiting constituencies, decision-makers pay heed to demographic and social processes, to create a fairer and more sustainable geographical framework. The doctoral dissertation seeks to contribute to this.

Before outlining the research questions of the doctoral dissertation, it is necessary to introduce the conceptual framework of the geographical factors affecting electoral systems. Collectively, territorial processes that create unequal political representation are called geographical bias. According to international literature, the factors causing geographical biases can be divided into three groups. One of them is malapportionment, which means the electoral inequality in the number of eligible voters and the consequent differences in party support. The theoretical effect of malapportionment on election day is modified, amplified, or mitigated by spatial differences in participation and credentials, which is known as reactive malapportionment. Finally, the notion of gerrymandering includes all phenomena that alter the spatial distribution of political party support by redrawing the boundaries of constituencies. In our case, homogenized and mixed constituency types can be detected. The international theoretical frameworks are only partially applicable to Hungary due to the different electoral and party systems, but their adaptation is crucial. Therefore, in my dissertation, I created an applicable model for Hungary.

My theoretical conclusion is that besides the static causal interpretation of geographic influencing factors, the interactions between gerrymandering, malapportionment and reactive malapportionment are the factors, which influence the nature of geographical bias. Consequently, Ph.D. research has undertaken to investigate the geographical bias of the Hungarian electoral system, such as gerrymandering, malapportionment, and reactive malapportionment. 
In my doctoral dissertation, I primarily sought to find out what geographical biases characterized the Hungarian electoral system between 2002 and 2018 and how did they change over time? In addition to the main research question, I also formulated four further questions to cover the topic:

- What are the connections among malapportionment, gerrymndering and reactive malapportionment?

- After 2002 at the level of constituencies how has the geographical pattern of electoral support of the parties getting into the parliament changed?

- What was the role of malapportionment after the turn of the millenium concerning the demarcation of the Hungarian constituencies?

- How was the effect of malapportionment modified by the participation and the territorial differences of the votes not being taken into consideration when counting the mandates?

- What was the extent of gerrymandering in the Hungarian electoral system following the turn of the millenium?

By answering the research questions it primarily required the use of quantitative methods, because the chosen geographical scale and time interval allow this approach. During the research, I used the list data of the 2002 and 2018 parliamentary elections. Besides, social and statistical data at municipal and constituency levels were needed to determine the demographic and social relationships affecting geographical factors. These were collected from the databases of the Hungarian Central Statistical Office, the National Election Office and the National Regional Development and Information System (TEIR). In addition to the data needed for the calculations, I made basic maps of the previous and current constituency positions for geographic and geoinformatics analysis.

After systematizing the data and drawing the electoral maps, I made several mathematical and statistical calculations, which revealed the geographical bias of the Hungarian electoral system. As a first step, I made an international comparison by comparing mandate and vote ratios and then revealed the general disproportion of the Hungarian electoral system with the Loosemore-Hanby and Gallagher indices. Then I turned to the geographic factors. Descriptive statistics of the constituency data formed the basis for later complex computational tasks. I used hierarchical and K-centered cluster analysis to determine the country's constituency-level political division between 2002 and 2018, where the listings of the parties included in the parliament formed the input data set. In addition to defining electoral geography, Pearson correlation, Spearman's rank correlation, and linear regression were used to detect geographical bias and social cleavages. I investigated the phenomenon of gerrymandering with the equality of the spatial distribution of party votes, for which I calculated the coefficient of variation, Herfindahl-Hirschman-index, Hoover and Gini indexes. In addition to the difficulty of selecting the appropriate indicators, the chosen territorial scale also influences the results several times, so I also used other territorial statistical methods. Thus, for the interpretation of the settlementlevel neighborhoods covered by the constituencies, I calculated Anselin's Local Moran's and Getis-Ord's local spatial autocorrelation and computed a geographically weighted regression to explore causal relationships. Mathematical and statistical analyzes were carried out with Microsoft Excel and IBM SPSS 22,23,24, and ArcMap 10.3 and Mapinfo Professional 10.0 software.

Seats-to-vote ratios show that post-socialist countries have lower overall disproportion in listed electoral systems and higher in mixed ones. Moreover, not only is the electoral system distorting the results, but the local character of the party structure is also important, so the same system may show another disproportion between the existence of two dominant parties or more 
pluralistic frameworks. In the countries examined, electoral systems generally gave the winning parties a margin of 1.1-1.3. Hungary's extremely disproportionate value in the nineties (1.64) later flattened to the region average, and again, following the new electoral law, showed the region's highest value (1.49). The reason for this was the transformation of the Hungarian party structure, and then the mechanism of the new electoral system that also compensated the winners. The lower value in 2018 (1.36) indicates that over time, both political actors and voters have adapted and reacted (eg tactical voting) to the changed new framework.

It is not enough to examine the fairness of the distribution of mandates by the proportion of mandates of the winning parties, so in the example of Hungary's 2010, 2014 and 2018 parliamentary elections, I have shown the general disproportionality of the electoral system with the Loosemore-Hanby and Gallagher indices. The volatility of the indices reflects the increase in the weight of the majority of the constituents, as $45.6 \%$ of mandates were previously obtained in individual constituencies, which changed to 53.3\%. Another change is that the twoballot election so far has been replaced by a single-ballot, making it a relative victory in the districts. This shows that the new system allocates individual mandates more disproportionately compared to the previous framework condition, while listing seats is relatively more proportionate, which eliminated the principle of compensation. One of the technical reasons for this is the winner's bonus, where additional votes cast for the winning candidate are also included, and the other is the appearance of cross-border votes. Finally, the Loosemore-Hanby and Gallagher indexes are already partially indicative of the impact of geographical delimitation, as the distribution of roll-call votes has become more proportionate with the disappearance of county scale. By 2018, the scale of the modifying effects of changing party structures and voter behavior will be less pronounced.

The geographical characteristics of the support of parties entering parliament during the period under review can be divided into two broad groups based on hierarchical and K-mean cluster analysis. The 2002 and 2006 elections can be described by four specific clusters and the 2010-2018 elections by five specific clusters. The results of the 2002 parliamentary elections redrew the earlier geographical features of electoral behavior. In the countryside, there was a sharp rift between the right and left, whereas, in the capital and its agglomeration, socialists and liberals had a strong voting base. Besides, in 2002 the number of districts similar to the national average was high. The results of the 2006 parliamentary elections have strengthened the space structure four years earlier, but two changes have already projected the success of the conservative side. The base of the Fidesz-KDNP has increased significantly in rural areas, while in the more liberal centers, the MSZP has already been defeated. The socialists could only perform well above their average in declining industrial districts and Budapest, but also strengthened in their rural bases, but could not acquire new territories in space. Finally, the deepening of the right-to-left divide has been marked by a significant reduction in the number of districts converging to the national average.

In 2010, there was a marked spatial rearrangement of voter behavior. In terms of results, we have been able to characterize our country with a certain degree of stability over the past decade, as the political dominance of the Fidesz-KDNP has characterized the decade and the role of geographical differences has been devalued. However, when analyzing the differences in detail in space, we could see dynamic shifts, especially among opposition camps, but also in the territorial concentration of ruling party voters. After 2010, the traditionally left-wing polling station Jobbik strengthened in major rural lagging areas, while the MSZP was declined. Thus, between 2010 and 2018, instead of the previous four, five constituent electoral clusters could be characterized, which were not altered by the redrawing of borders. However, the fractures created by economic, social and political processes (mainly the urban-rural divide) have been strengthened, which also partly determined the spatiality of party identity. It can be stated that this new district division did not solve it, but it caused the permanent stabilization of the fracture lines mainly in the vicinity of big cities by too concentrated or mixed demarcation. 
Even in the first application of the former constituency system, there were large differences, which had increased since the late 1990s as a result of internal migration processes, significantly violating the principle of equal voting. So there was a need to rethink constituencies and reduce disparities. Based on the statistical analysis, I found that between 2002 and 2010 the territorial distribution of the electorate at constituency level did not have a significant correlation with the list results of either party. Thus, the malapportionment did not put any party in advance, despite the marked differences in the number of eligible voters. This situation has changed in the new electoral system. Pearson correlation values from the results of 2014 and 2018 show that there was a significant negative co-movement of electoral constituencies with the Fidesz-KDNP list. So where fewer people are eligible voters, FideszKDNP performed better and vice versa. It can be stated that the factor of malapportionment favored the present ruling parties to a small extent, while it did not position or hinder the others. The moderate negative correlation between the Fidesz-KDNP and the electorate ratios has been reduced by 2018, while the relationship with other parties has remained insignificant.

In earlier constituencies system, turnout-weighted values have already shown weak correlations with smaller parties had support. Between 2002 and 2010, the support of the SZDSZ, the MDF, and the LMP was in direct proportion to the size of the constituencies, while the opposite was the case for Jobbik. Including roll-call votes that were not included in the distribution of credentials, the trend depicted by weighted differences in attendance has not changed significantly. There was no significant relationship between the two major parties between 2002 and 2010, and neither was triggered by reactive malapportionment. Jobbik was favored in 2010 by the district-wide inequality of the votes cast, while the SZDSZ, the MDF, and the LMP were at all disadvantages.

In the district elaboration of the new electoral law, the previous picture changed and in 2014 and 2018 there were significant and larger comovements. Adding participation to the current constituency malapportionment factor will result in perceptible reactive malapportionment in the new electoral system. On the one hand, the Fidesz-KDNP favored factors that were strengthened by being above average in districts where fewer voters produced lower turnout and low support where more voters showed higher turnout. On the other hand, weights can be observed. After the neutral effect of the system disappears and the effect of reactive malapportionment can be detected on all opposition parties. From the correlation values it can be concluded that while Jobbik was positively supported (in 2014 more than Fidesz-KDNP, not in 2018) by the new division of space, the parties that can be linked to the liberal side (DK, Együtt, LMP, MSZP, MLP, MSZP) have always been adversely affected by the new constituency position. Thus, in addition to the possible manipulation of intent, the party preference and active involvement of voters (eg neighborhood influence) reinforced the real geographical bias of the Hungarian system.

When analyzing the gerrymandering factors of the constituency, the geographical concentration of large parties and medium and small parties can yield results. Against this background, in 2002 and 2006, MSZP and SZDSZ were placed in a previous position, while Fidesz-MDF, then Fidesz-KDNP and MDF suffered a competitive disadvantage. By 2010 the cube, with the electoral system unchanged, had become a major beneficiary of the influence of gerrymandering on the Fidesz-KDNP, while the MSZP had suffered a moderate disadvantage due to its shrinking to the center party. Based on the national results of Jobbik and the LMP, the spatial concentration of their voters still seemed positive. Then, by changing the constituencies, the values and the dimension of gerrymandering changed.

In the new electoral system by 2014, gerrymandering was already being shaped by the reassignment. Compared to the 2010 national results, the opposition has been able to improve, but voters have shown greater concentration than before. This was an advantage in the political environment of that time, as they gained mandates for example in Budapest, Miskolc, and Szeged. However, in a fierce race, the liberal opposition parties would have been in a worse 
position than in 2010.

By 2018, despite a reorganization of national party politics and opposition votes, no significant change had taken place in this process. Tactical voting was once again an advantage for mid and small parties in the practice of the 2018 election. Due to the strong concentration of the LMP, but mainly the MSZP-PM and DK voters, they were able to gain more individual mandates, while Jobbik's disadvantage was the more even distribution of supporters. If the results of the opposition are analyzed at the same time, they will not be favored, as, in the face of fierce competition, the distribution of votes in the Fidesz-KDNP is more effective in the current constituency. The spatial autocorrelation analyzes also confirm the differences in the settlements within the constituencies. From the settlement values, concentrated and mixed basic types of gerrymandering can be determined. Mixed gerrymandering can be observed in Western Transdanubia and Veszprém County, wherein the constituencies the left-hand bases of the larger urban settlements were associated with highly above-average right-wing rural areas. This is indicated by the patterns of high-low area autocorrelation categories. In contrast, for example, in the catchment areas of Miskolc, Nyíregyháza, Pécs, Szeged, and Tatabánya, the concentration at the settlement level is high or high, which referred to homogenization when compared to the district boundaries. There was no such pronounced pattern and divergence between Jobbik and LMP within the constituency boundaries.

However, it is important to emphasize that due to the complexity of the spatial organization and political opinion-forming in society, by drawing the boundaries of constituencies, decision-makers can only partially influence the nature of electoral manipulation. Economic, political and social processes are not necessarily linearly linked to election results. Therefore, in addition to analyzing gerrymandering, the discovery of valuemodifying factors (eg, it is difficult to create constituencies in housing estates due to the real spatial concentration of voters, etc.) may also merit further scientific research. Besides, voters have a significant influence on the gerrymandering factor through their activity, which is also influenced by indirect factors behind electoral behavior, such as neighborhood effects, social fractures, social networking, and the effects of online and offline communication.

Further theoretical and methodological research on the topic may be possible. In the fieldspecific theoretical study of the principle of one-man-one-vote, it may be important to assess, through international examples, the distorting effect of other factors (eg preferential voting, campaign strategies, etc.) on the distribution of mandates. Explanation of these theoretical factors and their detection in different sample plots could clarify the diversity of geographical bias. Besides, research on geographic bias such as malapportionment and gerrymandering can have a significant scientific benefit in the internal election geographic analysis of larger settlements. Thus, in addition to extending the theory, refining the computation and mapping of geographical factors by including and modeling polling data could help to refine the analysis in metropolitan areas. Furthermore, the investigation of the complex dynamic relationships of gerrymandering, malapportionment, and reactive malapportionment, outlined in the dissertation, could be extended to the electoral system of neighboring post-socialist countries, once properly adapted.

In the case of Hungary, repeating the study at a later date (following the parliamentary elections of 2022 and 2026) would provide an opportunity to further monitor the temporal variation of the factors, including longer-term electoral processes. It is also necessary to recognize the shortcomings of the analyzes and their methodological limitations and to refine them later. Because the size differences in the current ranks of the constituencies again violate the statutory framework, they can redesign the roster at any time. In this case, the influence of the decision-makers on the system can be examined again. At this point, the dissertation can provide practical guidance as well, as the demographic and social processes behind the delimitation of constituencies can lead to more sustainable and equitable redistricting decisionmaking. 


\section{Felhasznált irodalom}

1. Agg Z. - Nemes Nagy J. 2002: A politika térségi és helyi szintjei. - In: Bernek Á. (szerk.): A globális világ politikai földrajza. Nemzeti Tankönyvkiadó, Budapest. pp. 385-430.

2. Agnew, J. 1996: Mapping politics: how context counts in electoral geography. - Political Geography. 15. 2. pp. $129-146$.

3. ANGElusz R. - TARDOS R. 2011: Régi és új törésvonalak, polarizáció, divergenciaspirál. In: TARDOS R. ENYEDi Zs. - SZABÓ A. (szerk.): Részvétel, képviselet, politikai változás. Demokrácia Kutatások Magyar Központja Alapítvány, Budapest. pp. 347-382.

4. AlPEK, B. L. - TÉSITS, R. 2018: Measuring Regional Differences in Labour Market Sensitivity in Hungary. - Applied Spatial Analysis And Policy. 11. 4. pp. 640-658.

5. AlPEK, B. L. - TÉsits, R. - HovÁnYI, G. 2018: Spatial Inequalities of Disadvantage Accumulation and their Impact on Employability in Hungary. - Regional Statistics. 8. 1. pp. 135-152.

6. Altman, M. 1995: Modeling the effect of mandatory district compactness on partisan gerrymanders. Political Geography. 17. 8. pp. 989-1012.

7. Altman, M. 2002: A Bayesian approach to detecting electoral manipulation. - Political Geography. 21.1. pp. 39-48.

8. ANSELIN, L. 1995: Local Indicators of Spatial Association-LISA. - Geographical Analysis. 27. 2. pp. 93-115.

9. Ács N. 2004: A választások jogi alapjai. - In: SzOBOSZLAI Gy. (szerk.): A közjogi választások egyes elméleti és gyakorlati kérdései. Magyar Közigazgatási Intézet, Budapest. pp. 123-145.

10. BAARS, R. - Schlottmann, A. 2015: Spatial multidimensionalities in the politics of regions: Constituting the 'Phantom Region' of Central Germany. - Erdkunde. 69. 2. pp. 175-186.

11. BABBIE, E. 2017: A társadalomtudományi kutatás gyakorlata. - Balassi Kiadó, Budapest. 744 p.

12. BAJMÓCY P. 1999: A szuburbanizáció sajátosságai Pécs környékén. - Földrajzi Értesítő. 48. 1-2. pp.127-138.

13. BАлмÓCY P. 2000: A "vidéki " szuburbanizáció Magyarországon, Pécs példáján. Tér és Társadalom. 14. 2-3. pp. 323-330.

14. BAJMÓCY P. 2003: Szuburbanizáció a Budapesti Agglomeráción kívüli Magyarországon. - Doktori Értekezés. Szegedi Tudományegyetem, Természettudományi és Informatikai Kar, Gazdaság- és Társadalomföldrajz Tanszék. 131 p.

15. BAJMÓCY P. 2006: A hazai szuburbanizációs folyamatok trendjei 2000 után. - In: CsAPó T. - Kocsis Zs. (szerk.): Agglomerációk és szuburbanizálódás Magyarországon: Településtudományi konferencia. Savaria University Press, Szombathely. pp. 112-127.

16. BАJMÓCY Z. 2011: Bevezetés a helyi gazdaságfejlesztésbe. - JATEPress, Szeged. 216 p.

17. BALOGH L. 2012: Kormányformák, választási rendszerek, választások Kelet- és Kelet-Közép-Európában. ELTE Eötvös Kiadó, Budapest. 218 p.

18. BARABÁSI AlBert L. 2016: A hálózatok tudománya. - Libri Könyvkiadó, Budapest. 446 p.

19. BARABÁsi AlBert L. 2018: A képlet - A siker egyetemes törvényei. - Libri Könyvkiadó, Budapest. 280 p.

20. BAYER J. 2000: A politikatudomány alapjai. - Napvilág Kiadó, Budapest. 431 p.

21. BÁNYÁSZ P. 2019: A közösségi média szerepe a választásokban. - Nemzetbiztonsági Szemle. 7. 1. pp. 85 105.

22. BENE M. 2018: Megosztásból szavazat. A Facebook-kampány hatása az egyéni választókerületi képviselőjelöltek választási eredményére a 2014-es országgyülési választásokon. - Politikatudományi Szemle. 27. 1. pp. 41-62.

23. BENOIT, K. 2004: Models of electoral system change. - Electoral Studies. 23. 3. pp. 363-389.

24. BeluszKy P. 1999: Magyarország településföldrajza. - Dialóg Campus Kiadó, Budapest. 586 p.

25. BERÉNYI B. E. 2016: Dzsentrifikációkutatás a Poszt-Szocialista városokban - Merre tovább? - Földrajzi Közlemények. 140. 3. pp. 204-215.

26. BeRnAUER, J. - BOCHSLER, D. 2011: Electoral entry and success of ethnic minority parties in Central

27. and Eastern Europe: A hierarchical selection model. - Electoral Studies. 30. 4. pp. 738-755.

28. BeRTUS Z. 2016a: Választási aktivitás területi vizsgálata Magyarországon a 2010-2014 közötti időszakban. - In: PAJTóKné TARi I -Tóth A (szerk.): Magyar Földrajzi Napok konferenciakötet. Agria Geográfia Alapítvány, Eszterházy Károly Egyetem, Eger. pp. 641-649.

29. BeRTUS Z. 2016b: A radikális jobboldal megjelenése a különböző településtípusokban. -Településföldrajzi Tanulmányok. 5. 2. pp. 70-79.

30. BERTUS, Z. 2017: Investigating the background of radical right-wing mobilization in Hungary with regional statistical methods. - Regional Statistics. 7. 2. pp. 190-208.

31. Birch, S. - Millard, F. - Popescu, M. - Williams, K. 2002: Embodynig democracy. - Palgrave Macmillian, New York. 236 p. 
32. BiRó P. - SzIKLAi B. - KóCZY Á. L. 2012: Választókörzetek igazságosan? - Közgazdasági Szemle. 59. 11. pp. 1165-1186.

33. Blazek, J. - Kostelecky, T. 1991: Csehországi parlamenti választások 1990. - Tér és Társadalom. 5. 2-3. pp. 39-54.

34. BOCHSLER, D. 2010: Measuring party nationalisation: A new Gini-based indicator that corrects for the number of units. - Electoral Studies. 29. 1. pp. 155-168.

35. Bódi F. - BóDi M. 2011: Hol vannak a választók? - Politikatudományi Szemle. 20. 1. pp. 51-74.

36. Borisyuk, G. - Johnston, R. - Thrasher, M. - RAllingS, C. 2008: Measuring Bias: Moving from a twoparty to three party elections. - Electoral Studies. 27. 2. pp. 245-256.

37. Borisyuk, G. - Johnston, R. - Thrasher, M. - RAllings, C. 2009: Parliamentary constituency voundary reviews and electoral bias: How important are variations in constituency size? - Parliamentary Affairs. 63.1. pp. 4-21.

38. Borisyuk, G. - Johnston, R. - Thrasher, M. - Rallings, C. 2010: A method for measuring and decomposing electoral bias for the three-party case, illustrated by the British case. - Electoral Studies. 29. 4. pp. 733-745.

39. BORISYUK, G. 2012: Developing methods for understanding the nature of voting patterns and party competition in Britain. - Doctor of Philosophy (PhD) dissertation, Plymouth University, Plymouth. 38 p.

40. Boros L. 2012: Földrajz és társadalomelméletek. - In. PÁL V. (szerk.): A társadalomföldrajz lokális és globális kérdései: tiszteletkötet Dr. Mészáros Rezső professzor 70. születésnapja alkalmából. SZTE TTIK Gazdaság- és Társadalomföldrajz Tanszék, Szeged. pp. 146-161.

41. Boros, L. - FAbUla, Sz. - Horváth, D. - Kovács, Z. 2016: Urban diversity and the production of public space in Budapest. - Hungarian Geographical Bulletin. 65. 3. pp. 209-224.

42. Boros L. - Fabula Sz. 2017: A sokszínűség érzékelése és megítélése Józsefvárosban. - Regio: Kisebbség Kultúra Politika Társadalom. 25. 4. pp. 80-107.

43. BöHM A. 2003: A társadalom politikai tagoltsága. - In: PERCZEL Gy. (szerk.): Magyarország társadalmigazdasági földrajza. ELTE Eötvös Kiadó, Budapest. pp. 202-213.

44. Brookes, R. H. 1953: The butler analysis and the cube law: Seats and votes in New Zealand. - Political Science. 5. 2. pp. 37-44.

45. Brookes, R. H. 1959: Electoral distortion in New Zealand. - Australian Journal of Politics and History. 5. 2. pp. 218-223.

46. BROOKES, R. H. 1960: The analysis of distorted representation in two party, single-member elections. Political Science. 12. 2. pp. 158-167.

47. Coma, F. M. - LAGO, I. 2016: Gerrymandering in comparative perspective. - Party Politics. 24 2. pp. 1-6.

48. Cox, G. W. 1997. Making votes count: Strategic coordination in the World's Electoral Systems. - Cambridge University Press, Cambridge. 360 p.

49. Chen, J. - Rodden, J. 2013: Unintentional Gerrymandering: Political geography and electoral bias in legislatures. - Quarterly Journal of Political Science. 8. 3. pp. 239-269.

50. CsizmadiA A. 1963: A Magyar választási rendszer 1848-1849-ben: az első népképviseleti választások. Közgazdasági és jogi könyvkiadó, Budapest. 368 p.

51. Curtice, J. - Steed, M. 1986: Proportionality and exaggregation in the British electoral system. - Electoral Studies. 5. 3. pp. 209-228.

52. CZENE-JÓ M. 2019: Gerrymandering az Egyesült Államokban. Megmentheti-e a matematika a demokráciát? - Politikaktudományi Szemle. 28. 3. pp. 111-134.

53. Dingsdale, A. - Kovács Z. 1996: A return to socialism: The Hungarian general election of 1994. Geography. 81. 3. pp. 267-278.

54. DuSEK T. 2004: A területi elemzések alapjai. - ELTE Regionális Földrajzi Tanszék, Budapest. 240 p.

55. DuseK T. - Kotosz B. 2016: Területi Statisztika. - Akadémiai Kiadó, Budapest. 285 p.

56. EgEdy, T. - KovÁcs, Z. - SzABÓ, B. 2018: Changing geography of the creative economy in Hungary at the beginning of the 21st century. - Hungarian Geographical Bulletin. 67. 3. pp. 275-291.

57. ENYEDI Gy. 2012: Városi világ. - Akadémiai Kiadó, Budapest. 186 p.

58. ENYEDi Zs. - KÖRÖSÉNYI A. 2004: Pártok és Pártrendszerek. - Osiris Kiadó, Budapest. 304 p.

59. ERIKSON, S. R. 1972: Malapportionment, Gerrymandering, and Party Fortunes in Congressional Elections. The American Political Science Review. 66. 4. pp. 1234-1245.

60. ERIKSON, S. R. 2002: Sources of partisan bias in US congressional elections an update stimulated by Ron Johnston' s essay. Political Geography. 21. 1. pp. 49-54.

61. Fabula, Sz. - Boros, L. - Kovács, Z. - Horváth, D. - PÁL V. 2017a: Studentification, diversity and social cohesion in post-socialist Budapest. - Hungarian Geographical Bulletin. 66. 2. pp. 157-173.

62. Fabula, Sz. - Boros, L. - Horváth, D. - KovÁCs, Z. 2017b: DIVERCITIES: dealing with urban diversity: the case of Budapest. - Utrecht University, Utrecht. 172 p.

63. FAlus I. - Ollé J. 2008: Az empirikus kutatások gyakorlata: Adatfeldolgozás és statisztikai elemzés. - 
Nemzeti Tankönyvkiadó, Budapest. 342 p.

64. FARKAS GY. 2016: A politika és etnikai földrajz határmezsgyéin. Választási földrajzi elemzések DélSzlovákia járásaiban. - Modern Geográfia. 11. 2. pp. 19-35.

65. FÁBiÁn GY. 2017: Választási rendszerek Kelet-Közép-Európában. - Metszetek. 6.1. pp. 26-50.

66. FÁBIÁN Gy. - KovÁcs L. I. 1998: Voksok és mandátumok. - Villányi úti Konferenciaközpont és Szabadegyetem Alapítvány, Budapest. 142 p.

67. FÁBIÁN Zs. 2013: A földrajzilag súlyozott regresszió módszere és alkalmazhatósági példája. - Területi Statisztika. 53.1. pp. 5-20.

68. FERENCZ Z. 2015: A társadalmi részvétel és a nagyváros-térségi versenyképesség. - In. Szirmai V. (szerk.): A területi egyenlőtlenségektől a társadalmi jól-lét felé. - Kodolányi János Főiskola, Székesfehérvár. pp. 327348.

69. Fitzmaurice, J. 1995: The Hungarian election of May 1994. - Electoral Studies. 14. 1. pp. 77-80.

70. Fleiner, B. - NAGY, B. - TASNÁDI, A. 2017: Optimal partisan districting on planar geographies. - Central European Journal of Operations Research. 25. 4. pp. 879-888.

71. FODOR F. 1920: A magyarországi országgyülési képviselőválasztási kerületek térképei 1861-1915. -Magyar Béketárgyalások VILA. - VII/N. térkép, Budapest. 14 p.

72. FOREST, B. 2013: Redistricting and the elusive ideals of representation. - Political Geography. 32. 1. pp. 1517.

73. Fowler, B. 2003: The parliamentary elections in Hungary, April 2002. - Electoral Studies 22. 4. pp. 799807.

74. Fowler, B. 2007: Concentrated orange: Fidesz and the remaking of the Hungarian centre-right, 1994-2002. - Journal of Communist Studies and Transition Politics. 20. 3. pp. 80-114.

75. Gallagher, M. 1991: Proportionality, disproportionality and electoral systems. - Electoral Studies. 10. 1. pp. 33-51.

76. Gallagher, M. - Mitchel, P. 2005: Introduction to Electoral Systems. - In. Gallagher, M. - Mitchel, P. (eds.): The Politics of Electoral Systems. Oxford University Press, Oxford. pp. 3-24.

77. Gelman, A. - King, G. 1994: A unified method of evaluating electoral systems and redistricting plans. American Journal of Political Science. 38. 3. pp. 514-554.

78. GETIS, A. 1995: Spatial filtering in a regression framework: Examples using data on urban crime, regional inequality, and government expenditures. - In. ANSELIN, L. - FlORAX, R. (eds.): New directions in spatial econometrics. - Springer. Heidelberg. pp. 172-185.

79. Getis, A. - ORD, J. K. 1992: The Analysis of Spatial Association by use of Distance Statistics. - Geographical Analysis. 24. 3. pp. 189-206.

80. Gilman, R. 2002: Geometry and Gerrymandering. - Math Horizons. 10. 1. pp. 10-12.

81. Giugal, A. - Johnston, R. - Chiru, M. - Ciobanu, I. - Gavris, A. 2017: Gerrymandering and Malapportionment, Romanian Style: The 2008 Electoral System. - East European Politics and Societies and Cultures. 20.10. pp. 1-21.

82. Glassner, M. I. 1996: Introduction to Political. - In. Glassner, M. I. - Fahrer, C. (eds.): Political Geography. John Wiley and Sons inc, New York. pp. 5-35.

83. Grofman, B. - Koetzle, W. - Brunell, T. 1997: An Integrated Perspective on the Three Potential Sources of Partisan Bias: Malapportionment, Turnout Differences, and the Geographic Distribution of Party Vote Shares. - Electoral Studies. 16. 4. pp. 457-470.

84. GYÖRI F. 2011. A tehetségtérképektől a tehetségföldrajzig. - Tér és Társadalom. 25. 4. pp. 38-59.

85. Haggett, P. 2001: Geography: A Global Synthesis. 4th edition - Pearson Hall, New York. 864 p.

86. Haggett, P. 2006: Geográfia, globális szintézis. - Typotex Kiadó, Budapest. 842 p.

87. HALÁs, M. - KlAPKA, P. 2016: Functionality versus gerrymandering and nationalism in administrative geography: lessons from Slovakia. - Regional Studies. 56. 2. pp. 1-12.

88. HAJdú Z. 1992: A választási földrajz Nyugat-Európában. - Info-Társadalomtudomány. 22.1. pp. 71-76.

89. HAJDÚ Z. 2006: A 20. századi magyar parlamenti választások választási földrajzi kérdései. - Múltunk. 51.1. pp. 137-169.

90. HAJDÚ Z. 2017: Fodor Ferenc történeti-politikai földrajzi munkásságának kérdéséhez. - Történeti Földrajzi Közlemények. 5. 1. pp. 33-43.

91. Haug, S. 2008: Migration networks and migration decision-making. - Journal of Ethnic and Migration Studies. 34. 4. pp. 585-605.

92. HÁRS Á. 2010: Migráció és munkaerőpiac Magyarországon. Tények, okok, lehetőségek. - In: HÁRS Á. TóTH J. (szerk.): Változó migráció - változó környezet. MTA Etnikai-nemzeti Kissebbségkutató Intézet, Budapest. pp.15-53

93. Hegedüs G. 2007a: Az Alföld 1990 és 2006 közötti választásföldrajzi sajátosságainak áttekintése. - In: SzÓNOKY ANCSIN G. - PÁL V. - KARANCSI Z. (szerk.): A határok kutatója. Magyarságkutató Tudományos Társaság, Szeged - Szabadka. pp. 123-129.

94. HEGEDŰS G. 2007b: A választási aktivitás és az életminőség területi különbséginek néhány összefüggése 
Szegeden. - Földrajzi Értesítő. 56. 1-2. pp. 113-123.

95. Hegedüs, G. 2009: A Review of Gated Communities in Some Hungarian Cities. - Geographica Pannonica. 13.8. pp. 85-96.

96. HEGEDÜS G. 2012: Lakóparkok és környékük térkapcsolatainak vizsgálata magyarországi esettanulmányok alapján. - In. PÁL V. (szerk.): A társadalomföldrajz lokális és globális kérdései: tiszteletkötet Dr. Mészáros Rezső professzor 70. születésnapja alkalmából. SZTE TTIK Gazdaság- és Társadalomföldrajz Tanszék, Szeged. pp. 182-195.

97. HubAi L. 2001a: Magyarország XX. századi választási atlasza 1920-2000 I. kötet - Napvilág Kiadó, Budapest. 288 p.

98. HubAi L. 2001b: Magyarország XX. századi választási atlasza 1920-2000 II. kötet - Napvilág Kiadó, Budapest. $328 \mathrm{p}$.

99. HubAi L. 2001c: Magyarország XX. századi választási atlasza 1920-2000 III. kötet - Napvilág Kiadó, Budapest. 690 p.

100.HuBAi L. 2004: Választási földrajz. - In: SzobosZlAi Gy. (szerk.): A közjogi választások egyes elméleti és gyakorlati kérdései. Állami Nyomda Rt., Budapest. pp. 285-305.

101.Hubai L. 2018: Választási földrajz. - Dialóg Campus Kiadó, Budapest. 29 p.

102.HunG, Y.C. - CHEN, L.Y. 2019: Using Intelligent Clustering to Implement Geometric Computation for Electoral Districting. - ISPRS International Journal of Geo-Information. 8. 9. pp. 369-383.

103.IlonSZKI, G. - VÁRNAGY, R. 2016: Parliamentary elections in Hungary, 2014. - Electoral Studies. 43. 1. pp. 169-209.

104.IngleHART, R. 1977: The silent revolution: changing values and political styles among Western publics. Princeton University Press, New Jersey. 496 p.

105.IGNÁCZ K. 2005: A hatalom eszközei a választói akarat “korrigálására”. A törvényhatósági választások elvei és gyakorlata Budapesten a Horthy-korszakban. - Múltunk. 50. 1. pp. 210-237.

106.IGNÁCZ K. 2013: Budapest választ: Parlamenti és törvényhatósági választások a fóvárosban, 1920-1945. Napvilág Kiadó, Budapest. 200 p.

107.IGNÁCZ K. - SzABÓ B. 2014: Választási eredmények Budapest történelmi munkásnegyedeiben, 1994-2014. - Eszmélet. 104. 1. pp. 75-98.

108.Ishiy AMA, J. T. 1997: Transitional Electoral Systems in Post-Communist Eastern Europe. - Political Science Quarterly. 112. 1.pp. 95-115.

109.JANCZAK, J. 2015: Phantom borders and electoral behaviour in Poland. Historical legacies, political culture and their influence on contemporary politics. - Erdkunde. 69. 2. pp. 125-137.

110.JANKó F. - KOMORNOKI M. 2008: Szuburbanizáció és választási földrajz: átalakuló pártválasztás Budapest térségében. - Tér és Társadalom. 22. 4. pp. 115-134.

111.JEFFERSON, W. 2005: Regional cleavages in Turkish politics: An electoral geography of the 1999 and 2002 national elections. - Political Geography. 24. 4. pp. 499-523.

112.JehlickA, P. - Kostelecky, T. - SykorA, L. 1993: Czechoslovak Parliamentary Elections 1990: old Patterns, New Trends and Lots of Surprises. In: O'Loughlin, J. - Wusten, H. (eds.): The New Political Geography of Eastern Europe. Belhaven Press, London. pp. 235-254.

113.Johnston, R. 1977: Spatial structure, plurality systems and electoral bias. - The Canadian Geographer. 20. 3. pp. 310-328.

114.JohnStON, R. 1979: Class conflict and electoral geography. - Antipode. 11. 3. pp. 36-43.

115.Johnston, R. 1983: Campaign spending and voting in England: analyses of the efficacy of political advertising. - Environment and Planning C: Government and Policy. 1. 1. pp. 117-126.

116.Johnston, R. 2001: Out of the 'moribund backwater': Territory and territoriality in political geography. Political Geography. 20. 6. pp. 677-693.

117.Johnston, R. 2002a: Manipulating maps and winning elections: measuring the impact of malapportionment and gerrymandering. - Political Geography. 21. 1. pp. 1-31.

118.JOHNSTON, R. 2002b: If it isn't a gerrymander, what is it? - Political Geography. 21. 1. pp. 55-65.

119.Johnston, R. 2015: Which Map? Which Government? Malapportionment and Gerrymandering, UK-Style. - Government and Opposition. 50. 1. pp. 1-23.

120.Johnston, R. - RossiteR, D. - PATtie, C. 1999: Integrating and decomposing the sources of partisan bias: Brookes' method and the impact of redistricting in Great Britain. - Electoral Studies. 18. 3. pp. 367-378.

121.Johnston, R. - Pattie, C. 2011a: Tactical Voting at the 2010 British General Election: Rational Behaviour in Local Contexts? - Environment and Planning A: Economy and Space. 43. 6. pp. 1323-1340.

122.Johnston, R. - PATtie, C. 2011 b: Electoral Systems, Geography, and Political Behaviour: United Kingdom Examples. - In. WARF, B. - LEIB, J. (eds.): Revitalizing Electoral Geography. Ashgate Publishing Company, Burlington. pp. 31-57. 
123.Johnston, R. - Rohla, B. - MANLEy, B. - Jones, K. 2019: Voting for Trump and the electoral mosaics of US metropolitan areas: Exploring changing patterns of party support by neighborhood. - Cities. 86. 1. pp. 94-101.

124.Kavanagh, A. 2009: Electoral Cartography. - In. Kitchin, R. - THRIFT, N. (eds.): International Encyclopedia of Human Geography. Elsevier Science. Amsterdam, pp. 396-398.

125.KERESNYEI K. - EGEDY T. 2015: Adalékok a kreatív gazdaság elméletéhez. - Földrajzi Közlemények. 139. 1. pp. 30-42.

126.Kim, J. - Eliott, E. - MinG-WANG, D. 2003: A spatial analysis of county-level outcomes in US Presidential elections: 1988-2000. -Electoral Studies. 22. 4. pp. 499-523.

127.Kitschelt, H. 1995: Party Systems in East Central Europe: Consolidation or Fluidity? Centre for the Study of Public Policy. - University of Strathclyde, Glasgow. 103 p.

128.Kolossov, V. 1995: The Electoral Geography of the Former Soviet Union, 1989-91: Retrospective Comparisons and Theoretical Issues. - In. O'Loughlin, J. - Wusten, H. van DER (eds.): The New Political Geography of Eastern Europe. Belhaven Press, London. pp. 189-215.

129.KoRKUT, U. 2007. The 2006 Hungarian elections: economic competitiveness versus social solidarity. Parliamentary Affairs. 60. 4. pp. 675-690.

130.KovÁCs L. I. - STUMPF P. B. 2014: Az arányosságról a 2014-es parlamenti választás után. - Metszetek. 3.3. pp. 52-62.

131.KovÁCs Z. 1992: Az 1990. évi magyar választások földrajza. - Info-Társadalomtudomány. 22.1. pp. 57-70.

132.KovÁcs, Z. 1993: The geography of Hungarian parliamentary elections 1990. - In. O'LougHLIN, J. Wusten, H. VAN DER (eds.): The New Political Geography of Eastern Europe. Belhaven Press, London. pp. 255-273.

133.KovÁcs Z. 2000: Voksok a térben. A magyar parlamenti választások földrajzi jellemzői. - In.: GAZSÓ F. STUMPF I.- SzOBOSZlai Gy. (szerk.): Parlamenti választások 1998. Századvég Kiadó, Budapest. pp. 100115.

134.Kovács, Z. 2001: The Geography of Post-Communist Parliamentary Elections in Hungary. - In.: Meusburger, P. - Jöns, H. (eds.): Transformations in Hungary. Contributions to Economics. Physica, Heidelberg. pp. 249-271.

135.KovÁcs Z. 2007: Népesség-és településföldrajz. - ELTE Eötvös Kiadó, Budapest. 240 p.

136.Kovacs, Z. - Dingsdale, A. 1998: Whither East European democracies? The geography of the 1994 Hungarian parlamentary election. - Political Geography. 17. 4. pp. 437-458.

137.KovÁcs, Z. - VIDA, Gy. 2015: Geography of the new electoral system and changing voting patterns in Hungary. - Acta Geobalcanica. 1. 2. pp. 55-64.

138.KovÁCS, Z. - VIDA, GY. 2018: Malapportionment and gerrymandering in post-socialism: the Hungarian context. - In: PÉNZES J. (szerk.): Falu - város - periféria: határon innen és túl: Süli-Zakar István professzor emlékére. Didakt Kiadó, Debrecen. pp. 161-166.

139. KovALCSIK T. 2018: A Közép-magyarországi régió településeinek alternatív választókerületi térfelosztása. - Településföldrajzi Tanulmányok. 7. 1. pp. 54-69.

140.KoVALCSIK T. 2019: Társadalmi és politikai términtázatok aggregációs lehetőségei mikroléptéken, Budapest példáján. - In: Molnár V. É. (szerk.): Az elmélet és a gyakorlat találkozása a térinformatikában. Debreceni Egyetemi Kiadó, Debrecen. pp. 167-174.

141.KovalcSiK T. - NZIMANDE, N. P. 2019: Theories of the voting behaviour in the context of electoral and urban geography. - Belvedere Meridionale. 31. 4. pp. 207-220.

142.KovalcsiK T. - VIDA, GY. - DudÁs G. 2018: Kompaktsági mutatók használata a társadalomföldrajzi kutatásokban. - In: MolNÁr V. (szerk.) Az elmélet és a gyakorlat találkozása a térinformatikában IX. Debreceni Egyetemi Kiadó, Debrecen. pp. 187-194.

143. KovalcsiK T. - VIDA Gy. - DudÁs G. 2019: Az országgyülési választókerületek kompaktságának elemzése Magyarországon. - Területi Statisztika. 59. 2. pp. 188-218.

144.Kowalski, M. 1999: Electoral Geography in Poland. - In: DuRó A. (eds.): Spatial Research in Support of the European Integration. Centre for Regional Studies, Discussion Papers, Pécs. pp. 87-95.

145. Kozma T. - Márkus E. - Szabó B. - Benke M. - Erdei G. - Teperics K. - Tözsér Z. - GÁl Z. - Engler

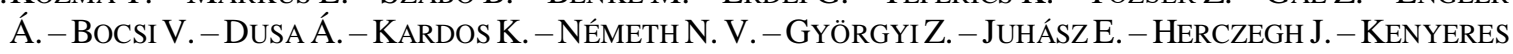
A. Z. - Kovács K. - Szabó J. - SzÜCs T. - Forray R. K. - Cserti Cs. T. - Heltai B. - Híves T. - MÁrtoN S. - SZILÁGYINÉ CZIMRE K. 2015: Tanuló régiók Magyarországon az elmélettől a valóságig. -A Debreceni Egyetem Felsőoktatási K\&F Központ, Debrecen. 296 p.

146.KóCZY, L. Á. - SZIKLAI, B. R. 2018: Operations Research Letters. - Operations Research Letters. 46. 3. pp. 324-328.

147.KÖZPONTI StATISZTIKAI Hivat AL 2018: Körkép a megyékről, 2018. Központi Statisztikai Hivatal, Budapest. 
$45 \mathrm{p}$.

148. KREHBIEL, E. 1916: Geographic Influences in British Elections. - Geographical Review. 2. 6. pp. 419-432.

149.Krugman, P. 1999: The Role of Geography in Development. - International Regional Science Review. 22. 2. pp. 142-161.

150.LEIB, J. - Quinton, N. 2011. On the Shores of the „Moribund Backwater”?: Trends in Electoral Geography Research Since 1990. - In. WARF, B. - LEIB, J. (eds.): Revitalizing Electoral Geography. Ashgate Publishing Company, Burlington. pp. 9-30.

151.Leib, J. I. - WebSTER, G. R. 2009: Electoral Districts. - In. Kithin, R. - ThrifT, N. (eds.): International Encyclopedia of Human Geography. Elsevier Science, Amsterdam. pp. 399-404.

152.LAGO, I. - LOBO, M. C. 2014: Partisan turnout bias and district magnitude. - Electoral Studies. 35. 1. pp. 150158.

153.LI, W. - ChEN, T. - WeNTZ, E. A. - FAN, C. 2014: NMMI: A mass compactness measure for spatial pattern analysis of areal features. - Annals of the Association of American Geographers. 104. 6. pp. 1116-1133.

154.LIPSET, S. M. - RoKKAIN, S. 1967: Cleavage structures, party systems and voter algiments: Introduction. In. LIPSET, S. M. - ROKKAIN S. (eds.): Party systems and voter algiments: Cross national perspectives. The free Press, New York. pp. 1-6.

155.Loosemore, J. - HandBy, V. J. 1971: The Theoretical Limits of Maximum Distortion: Some Analytic Expressions for Electoral Systems. - British Journal of Political Science. 1. 4. pp. 467-477

156.Low, M. 2005: States, city citizenship and collective action. - In: DANIELS, P. - BRADSHAW, M. - Shaw, D. - SIDAWAY, J. (eds.): Human Geography. SAGE, New York. pp. 473-493.

157.LöwIS, S. 2015: Phantom borders in the political geography of East Central Europe: an introduction. Erdkunde. 69. 2. pp. 99-106.

158. MARelyn K. J. - Hubai L. - TOldi L. - HoRváth Zs. 2017: A 2014-ben megválasztott Országgyülés Almanachja. - Magyar Országgyúlés, Budapest. 744 p.

159.MARTIN, S. 2015: Measuring phantom borders: the case of Czech/Czechoslovakian electoral geography. Erdkunde. 69. 2. pp. 139-150.

160.MARTIS, K. C. 2008: The original gerrymander. - Political Geography. 27. 8. pp. 833-839.

161. Martis, K. C. - Kovács, Z.- KovÁCs, D. - Peter, P. 1992: The geography of the 1990 Hungarian parliamentary elections. - Political Geography. 11. 3. pp. 283-305.

162.MASSiCOTTE, L. Blais, A. 1999: Mixed electoral systems: a conceptual and empirical survey. - Electoral Studies. 18. 3. pp. 341-366.

163. MezŐ F. 2003: A politikai földrajz alapjai. - Debreceni Egyetem Kossuth Egyetemi Kiadó, Debrecen. 390 p.

164.MÉSZÁROS J. - SZAKADÁT I. 1993: Választási eljárások választási rendszerek. - BME Szociológia Tanszék, Budapest. $77 \mathrm{p}$.

165.MÉSZÁRos J. - SzAKADÁT I. 1995: Magyarország politikai atlasza. - Konrad Adenauer Alapítvány, Budapest. 120 p.

166.MÉsZÁros J. - SZAKADÁT I. 1999: Magyarország politikai atlasza 1998. - Osiris, Budapest. 120 p.

167.MÉSZÁros, J. - SOLYMOSI, N. - SPEISER, F. 2007: Spatial distributiuon of political parties in Hungary 19902006. - Political Geography. 26. 7. pp. 804-823.

168.MÉSZÁros R. 2010: Alapkategóriák, összefüggések, példák. - In. MÉSZÁros R. (szerk.): A globális gazdaság földrajzi dimenziói. - Akadémiai Kiadó, Budapest. pp. 21-39.

169.MONROE, B. L. 1994: Disproportionality and malapportionment: Measuring electoral inequity. - Electoral Studies. 13. 2. pp. 132-149.

170.MolNÁR T. 2015: Empirikus területi kutatások. - Akadémiai Kiadó, Budapest. 207 p.

171.MOORE, T. 2002: Comments on Ron Johnston's „Manipulating maps and winning elections: measuring the impact of malapportionment and gerrymanering”. - Political Geography. 21. 1. pp. 33-38.

172. MORILL, R. 1973: Ideal and reality in reapportionment. - Annals of the Association of American Geographers. 63. 4. pp. 463-477.

173.Morill, R. - KNopp, L. - Brown, M. 2007: Anomalies in red and blue: Exceptionalism in American electoral geography. - Political Geography. 26. 5. pp. 525-553.

174.MoRILL, R. 2009: Gerrymandering. - In. Kitchin, R. - THRIFT, N. (eds.): International Encyclopedia of Human Geography. Elsevier Science. Amsterdam. pp. 486-491.

175.MORTIMORE, R. 1992: The constituency structure and the boundary commission: the rules for the redistribution of seats and their effect on the British electoral system 1950-1987. - D. Phil thesis, University of Oxford. $40 \mathrm{p}$.

176.NAGY, G. 2007: Changes in the political landscape in Hungary and the South Great Plain between 19902006. - In: KovÁcs Cs. (szerk.): From villages to cyberspace. Department of Economic and Human Geography, University of Szeged. pp. 401-415. 
177.NemES NAGY J. 1998: Tér a társadalomkutatásban. - Hilscher Rezső Szociálpolitikai Egyesület, Budapest. $261 \mathrm{p}$.

178. NeMES NAGY J. 2009: Terek, helyek, régiók. - Akadémiai Kiadó, Budapest. 356 p.

179.NeWman, P. - JENNINGS, I. 2008: Cities as a sustainable ecosystems. Principles and practices. Islandpress, Wasington. $285 \mathrm{p}$.

180.NÉMETH N. 2005: Területi egyenlőtlenségi mutatók. - In.: NEMES NAGY J. (szerk.): Regionális elemzési módszerek. - ELTE Regionális Földrajzi Tanszék és az MTA-ELTE Regionális Kutatócsoport kiadványsorozata, Budapest. pp. 116-128.

181.NiCLEY, E. P. 2011: Elections and cultural political economy: The political geography of the Bloque Nacionalista Galego in the Galicia Autonomous Community. - In. WARF, B. - LEIB, J. (eds.): Revitalizing Electoral Geography. Ashgate Publishing Company, Burlington. pp. 75-96.

182.ONG, K.M. - KASUYA, Y. - MORI, K. 2017: Malapportionment and democracy: A curvilinear relationship. Electoral Studies. 49. 1. pp. 118-127.

183. Openshaw, S. 1984: The modifiable areal unit problem. - Geobooks, Norwich. 40 p.

184.PAINTER, J. - JEFFREY, A. (2009): Political geography: An introduction to space and power (second edition). -SAGE, London. 248 p.

185.Pattie, C. - Johnston, R. 2009: Electoral Geography. - In. Kithin, R. - Thrift, N. (eds.): International Encyclopedia of Human Geography. Elsevier Science, Amsterdam. pp. 405-422.

186.PATtie, C. - Johnston, R. 2014: 'The electors shall meet their respective states': Bias and the US presidential electoral college, 1962-2012. - Political Geography. 40. 1. pp. 35-45.

187.PÁSZTOR I. Z. 2013: Társadalomföldrajzi vizsgálatok az északkelet-magyarországi romaság körében (Létszámváltozások, önkormányzatiság, kisebbségi választások). - Doktori (PhD) értekezés, DE TTK, Debrecen. 179 p.

188.PÉnZes J. - TÁtrAi P. - PÁSZTOR I. Z. 2018: A roma népesség területi megoszlásának változása Magyarországon az elmúlt évtizedekben. - Területi Statisztika. 58.1. pp. 3-26.

189.POPESCU, M. - TÓKA G. 2008: Districting and Redistricting in Eastern and Central Europe: Regulations and practices - In: HANDLEY, L. - GROFMAN, B. (eds.): Redistricting in comparative perspective. Oxford University Press, Oxford. pp. 251-287.

190.PRESCOTT, J. R. V. 1959: The function and methods of electoral geography. - Annals of the Assosiation of American Geographers. 49. 3. pp. 296-304.

191.Quinton, N. 2013: Political criteria, political praxis. - Political Geography. 32. 1. pp. 18-20.

192.RAMmELT, H. 2015: Shadows of the past: Common effects of communism or different pre-communist legacies? An analysis of discrepancies in social mobilization throughout Romanian regions. - Erdkunde. 69. 2. pp. 151-160.

193.RAWLS, J. 1971: Theory of justice. - Harvard University Press, Cambridge. 607 p.

194.RAWLS, J. 1997: Az igazságosság elmélete. - Osiris Kiadó, Budapest. 735 p.

195.RÁCZ, B. 2003: The left in Hungary and the 2002 parliamentary elections. - Europe-Asia Studies. 55. 5. pp. 747-769.

196.RÁCZ, B. - KUKORELLI, I. 1995: The 'second-generation' post-communist elections in Hungary in 1994. Europe-Asia Studies. 47. 2. pp. 251-279.

197.Regt, S. - Mortelmans, D. - Smits, T. 2011: Left-wing authoritarianism is not a myth, but a worrisome reality. Evidence from 13 Eastern European countries. - Communist and Post-Communist Studies. 44. 4. pp. 299-308.

198.RICE, S. 1928: Quantitative methods in politics. - A.A. Knopf, London. 331 p.

199.SAJTos L. - Mitev A. 2007: SPSS Kutatási és Adatkezelési kézikönyv. - Alinea Kiadó, Budapest. 404 p.

200.SAUER, C. O. 1918: Geography and gerrymander. - The American Political Science Review. 12. 3. pp. 403426.

201.SAuger, N. - GrofMAN, B. 2016: Partisan bias and redistricting in France. - Electoral Studies. 44.1. pp. 388396.

202.SÁNTA É. - SZAKÁLNÉ KANÓ I. - LENGYEL I. 2015: Csökkennek az iskolázottság területi egyenlőtlenségei? A felsőfokú végzettségüek területi eloszlása a népszámlálások adatai alapján, 1990-2011. - Területi Statisztika. 55. 6. pp. 541-555.

203.SEN, A. 2003: A fejlődés, mint szabadság. - Európa Kiadó, Budapest, 596 p.

204.SHELlEY, F. M. - JOHNSTON, R. - TAYLOR, P. 1990: „Developments in electoral geography” - In. JOHNSTON, R. - Shelley, F. M. - TAYLOR, P. (eds.): Developments in Electoral Geography. Routledge, London. pp. 111.

205.Shin, M.-Agnew, J. 2011: Spatial regression for electoral studies: The case of the Italian Lega Nord. - In. WARF, B.- LEIB, J. (eds.): Revitalizing Electoral Geography. Ashgate Publishing Company, Burlington. pp. 59-74. 
206.SiEgFrIED, A. 1913: Tableau politique de la France de l'Ouest sous la Troisieme République. Armand Colin, Paris: Részlet magyarul Nyugat-Franciaország politikai térképe a Harmadik Köztársaság idején. - In: HASKÓ K. - SzÉNÁSI, É. (szerk.): Válogatás a francia politikatudományból. Villányi úti könyvek, Budapest. 1998. pp. 21-40.

207.STEgmaier, M. - Lewis-Beck, M. S. 2009: Learning the economic vote: Hungarian forecasts, 1998-2010. - Politics and Policy. 37. 4. pp. 769-780.

208.Stegmaier, M. - Lewis-Beck, M. S. 2011: Shocks and oscillations: The political economy of Hungary. Electoral Studies. 30. 3. pp. 462-467.

209.STEWART, B. 2018: From adversaries to allies: ethnic gerrymandering and ethnic party behaviour in local elections in Macedonia. - Nations and Nationalism. 24. 1. pp. 1-22.

210.StigliTZ, J. E. 2000: A kormányzati szektor gazdaságtana. - KJK Kerszöv Jogi és Üzleti Kiadó, Budapest. $748 \mathrm{p}$.

211.STUMPF P. B. 2019: Mozgósítási inkongruencia a magyar önkormányzati választásokon. - METSZETEK Társadalomtudományi folyóirat. 8.4. pp. 5-24.

212.SÜMEGHY D. - NÉMETH Á. 2018: Etnikai Diverzitás és a Szélsőjobboldal megerősödése Svédországban 1991 után. In: REMÉNYI P. - VERS R. (szerk.): Az iszlám és Közép-Európa Geopolitika és migráció, Magyar Földrajzi Társaság és a Pécsi Tudományegyetem Természettudományi Kar Földrajzi és Földtudományi Intézet, Politikai Földrajzi, Fejlödési és Regionális Tanulmányok Tanszéke, Pécs, pp. 267-277.

213.SZABÓ B. 2013: Az új parlamenti pártok szavazóbázisának jellemzői Budapest példáján. - Politikatudományi Szemle. 22. 3. pp. 92-116.

214.SzABÓ B. - TÁTRAI P. 2011: Területi különbségek a pártpreferenciákban Szlovákiában, 1990-2010. - Tér és Társadalom. 25. 4. pp. 61-80.

215.SzABÓ, B. - TÁTRAI, P. 2016: Regional and social cleavages in the Slovak elections after the change of the regime. - Geograficky Casopis. 68. 3. pp. 195-212.

216.SZAKÁLNÉ KANÓ I. 2011: A gazdasági aktivitás térbeli eloszlásának vizsgálati lehetőségei. - Statisztikai Szemle, 89. 1. pp. 77-100.

217.SZAKÁLNÉ KANÓ I. 2017: A gazdasági aktivitás térbeli eloszlásának vizsgálati lehetőségei. - In.: LENGYEL I. (szerk.): Két évtizedes a regionális tudományi mühely Szegeden 1997-2017. JATEpress, Szeged. pp. 357378.

218.SzÉKELY M. - BARNA I. 2008: Túlélőkészlet az SPSS-hez. Többváltozós elemzési technikákról társadalomkutatók számára. - Typotex Kiadó. Budapest. 453 p.

219.TASNÁDI, A. 2011: The political districting problem: a survey. - Society and Economy. 33. 3. pp. 543-554.

220.TAYLOR, P. J. - JOHnSTON, R. J. 1979: Geography of elections. - Harmondsworth: Penguin. London. pp. $487-$ 521.

221.TAYLOR, P. J. - OPENSHAW, S. 1979: A million or so correlation coefficients: three experiments on the modifiable areal unit problem. - In.: N. Wrigley, R. J. - BENNETT, R. L. MARTIN (eds.): Statistical applications in the spatial sciences. Pion, London. pp. 127-44.

222.TÉSITS, R. - ALPEK, B. L. - SZABÓ, R. 2015: Some social and regional lessons of a complex Roma integration program: Case study from a Hungarian rural area. - Eastern European Countryside. 21. 1. pp. 111-136.

223. То́тн G. 2003: Területi autokorrelációs vizsgálat a Local Moran I módszerével. - Tér és Társadalom. 17.4. pp. 39-49.

224.VASÁRUS G. - VIDA GY. 2014: A szuburbanizáció néhány választásföldrajzi sajátossága a hazai nagyvárosi agglomerációk példáján. - Településföldrajzi Tanulmányok. 3. 2. pp. 59-72.

225.VICKREY, W. 1961: On the Prevention of Gerrymandering. - Political Science Quarterly. 76. 1. pp. 105-110.

226. VIDA GY. 2013: Az új országgyülési választókerületi beosztás és a társadalmi igazságosság kérdése, Csongrád megye példáján. In: JóZSA, K. - NAGY GY. - DuDÁs R. (szerk.): Geográfus Doktoranduszok XIII. Országos Konferenciája SZTE Természettudományi és Informatikai Kar Gazdaság- és Társadalomföldrajz Tanszék, Szeged. 32. pp.1-15.

227.VIDA GY. 2014: Politikai törésvonalak a magyar társadalomban a 2014-es országgyülési választások alapján. In: Kóródi T. - SAnsumné Molnár J. - Siskáné Szilasi B. - Dobos E. (szerk.): VII. Magyar Földrajzi Konferencia kiadványa, Miskolc. pp. 668-677.

228.VIDA GY. 2016: Az egyenlőtlen politikai reprezentációt létrehozó választási földrajzi hatótényezők mérési lehetőségei. - Területi Statisztika. 56. 6. pp. 643-659.

229. VIDA, GY. - DudÁs, G. 2017: Geographical context of the revealed competitiveness of urbanised areas in Hungary excluding the Budapest agglomeration. - Geographica Pannonica. 21. 3. pp. 179-190.

230. VIDA GY. - KovÁcs Z. 2015: A magyar választási rendszer területi aránytalanságai 2011 előtt és után. Területfejlesztés és Innováció. 9. 1. pp 2-10. 
231.VIDA GY. - KoVÁCS Z. 2017: Magyarország átalakuló választási földrajza a 2010-es és a 2014-es parlamenti választások tükrében. - Földrajzi Közlemények. 141. 2. pp. 125-138.

232.VIDA Gy. - KovALCSIK T. 2018: Magyarország választási földrajzi sajátosságai a 2014-es és a 2018-as parlamenti választások tükrében. - Modern Geográfia. 13. 4. pp. 15-30.

233. WALKS, R. A. 2004: Place of residence, party preferences, and political attitudes in Canadian cities. - Journal of Urban Affairs. 26. 3. pp. 269-295.

234.WALKS, R. A. 2005: City-suburban electoral polarisation in Great Britain, 1950-2001. - Transactions of the Institute of British Geographers. 30. 4. pp. 500-517.

235.WALKS, R. A. 2006: he causes of city-suburban political polarisation? A Canadian case study. - Annals of the Association of American Geographers. 96. 2. pp. 390-414.

236.WARF, B. 2011. Class, Ethnicity, Religion and Place in the 2008 US Presidential Election. - In. WARF, B. LEIB, J. (eds.): Revitalizing Electoral Geography. Ashgate Publishing Company, Burlington. pp 134-156.

237. WARF, B. - LEIB, J. 2011: Introduction. - In. WARF, B. - LEIB, J. (eds.): Revitalizing Electoral Geography. Ashgate Publishing Company, Burlington. pp. 9-30.

238. Webster, G. R. 2013a: Reflections on current criteria to evaluate redistricting plans. - Political Geography. 32. 1. pp. 3-14.

239. Webster, G. R. 2013b: Normative goals and demographic realities. - Political Geography. 32. 1. pp. 21-22.

240.Webster, G. R. - Quinton, N. 2010: The electoral geographies of two segregationist („Jim Crow”) referenda in Alabama. - Political Geography. 29. 7. pp. 3-14.

241. Young, I. 1990: Justice and the Politics of Difference. - NJ: Princeton University Press. Princeton. 286p.

242.ZARYCKI, T. 1999: The New Electoral Geography of Central Europe. - Research Support Center, Praha. 81 p.

243.ZARYCKI, T. 2015: The electoral geography of Poland: between stable spatial structures and their changing interpretations. - Erdkunde. 69. 2. pp. 107-124.

244.ZuCCO, C. 2007: Where's the bias? A reassessment of the electoral system. - Political Geography. 26. 3. pp. 303-314.

\section{Jogszabályok}

1848. évi V. törvénycikk az országgyülési követeknek népképviselet alapján választásáról

1989. évi XXXIV. törvény az országgyülési képviselők megválasztásáról

2/1990. (I. 11.) Minisztertanácsi Rendelet

1994. évi III. törvény az országgyülési képviselők választásáról szóló 1989. évi XXXIV. törvény módosításáról és kiegészítéséről

1997. évi XCVI. törvény az országgyülési képviselők választásáról szóló 1989. évi XXXIV. Törvény módosításáról

1997. évi C. törvény a választási eljárásról

22/2005. (VI.17.) Alkotmánybírósági határozat az egyéni választókerületek nagyságáról

2011. évi CCIII. törvény az országgyülési képviselők megválasztásáról

2013. évi XXXVI. törvény a választási eljárásról

\section{Felhasznált internetes források}

[1] http://www.valasztas.hu/ (Letöltés ideje 2013.06.15 és 2019.08.28 között)

[2] http://szavazatterkep.hu (Letöltés ideje 2014.04.26.)

[3] http://www.parties-and-elections.eu/ (Letöltés ideje 2019.04.14.)

[4] http://www.electionguide.org/ (Letöltés ideje 2019.05.05.)

[5] https://www.electoralgeography.com/new/en/ (Letöltés ideje 2019.03.10.)

[6] http://www.ksh.hu/nepszamlalas/tablak_vkerulet (Letöltés ideje 2014.10. 10.)

[7] https://www.teir.hu/ (Letöltés ideje 2019.06.15.)

[8] http://www.ksh.hu/nepszamlalas/docs/tablak/vkerulet/oevk_terkep.pdf (Letöltés ideje 2014.06. 15.) 


\section{Köszönetnyilvánítás}

A dolgozat nem készülhetett volna el azok nélkül, akik segítették munkámat. Szeretnék köszönetet mondani témavezetőmnek, Kovács Zoltánnak. Ö keltette fel érdeklődésemet a téma iránt és hallgatói éveim alatt szakmai témavezetésével sokat segített a nemzetközi szakirodalomban található irányzatok feltérképezésében. Emellett sok észrevételt tett a dolgozat szerkezeti felépítésével, belső logikájával kapcsolatban s elfoglaltsága ellenére volt ideje piros tollal részletesen átjavítani a dolgozat különböző fázisait.

Szeretném köszönetemet kifejezni Dudás Gábornak, aki időt nem sajnálva sokszor motivált és lényegre törő észrevételeivel, javaslataival segített formába önteni a dolgozat elméleti és gyakorlati részeit. Köszönöm továbbá Kovalcsik Tamás segítségét, amit a dolgozat adatbázisának összeállításában, egyes térképeinek és az illusztrációk elkészítésénél nyújtott. Többek között vele közösen született meg a társadalmi törésvonalak pókháló diagramja és mind módszertani, mind térképészeti szempontból hasznos tanácsokkal látott el. Továbbá szakmai beszélgetéseink hozzájárultak a dolgozat megírásához.

Köszönettel tartozom Hegedűs Gábornak, aki a $\mathrm{PhD}$ képzésem elején rendelkezésemre bocsájtotta a 2010 elötti választási térképet, amit használhattam, valamint a munkahelyi vitában alapos, lényegre törő észrevételeivel hozzájárult a dolgozat végső formába öntéséhez. Továbbá köszönettel tartozom a Gazdaság- és Társadalomföldrajz Tanszék munkatársainak, kiemelve Boros Lajost és Pál Viktort, akik biztosították a dolgozat megvalósulásához szükséges szellemi fejlődés hátterét. Továbbá hálás vagyok mindazoknak a kollégáknak és szakmai partnereknek, akik az elmúlt évek során segítségemre voltak akár egy építő kritikai észrevétellel, akár a dolgozat megírása során nyújtott motivációért.

Azt is külön megemlítem, hogy a doktori kutatásom megvalósításában és a disszertáció létrejöttében pénzügyileg több pályázat is hozzájárult. Doktori kutatásom részben az Emberi Erőforrások Minisztériuma ÚNKP-18-3 kódszámú Új Nemzeti Kiválóság Programjának támogatásával, az Innovációs és Technológiai Minisztérium ÚNKP-19-3 kódszámú Új Nemzeti Kiválóság Programjának, az Emberi Erőforrások Minisztériuma 20391-3/2018/FEKUSTRAT kódszámú, valamint az Innovációs és Technológiai Minisztérium TUDFO/47138-1/2019-ITM kódszámú támogatásával készült. Ezúton szeretném köszönetemet kifejezni a támogatásért.

Ezúton szeretném megköszönni nagyszüleimnek azt, hogy felkeltették érdeklődésemet a földrajzi folyamatok iránt, sajnos közülük már többen nem érhették meg e sorok létrejöttét. Végül, de nem utolsó sorban hálás vagyok és köszönettel tartozom Családomnak és a Páromnak a türelmükért és nehéz pillanatokban történő feltétel nélküli támogatásukért és szeretetükért. 


\section{Mellékletek}

1.melléklet: A választásra jogosultak százalékos aránya az országos átlaghoz viszonyítva a 176 egyéni választókerületben a 2002-es országgyưlési választás alapján

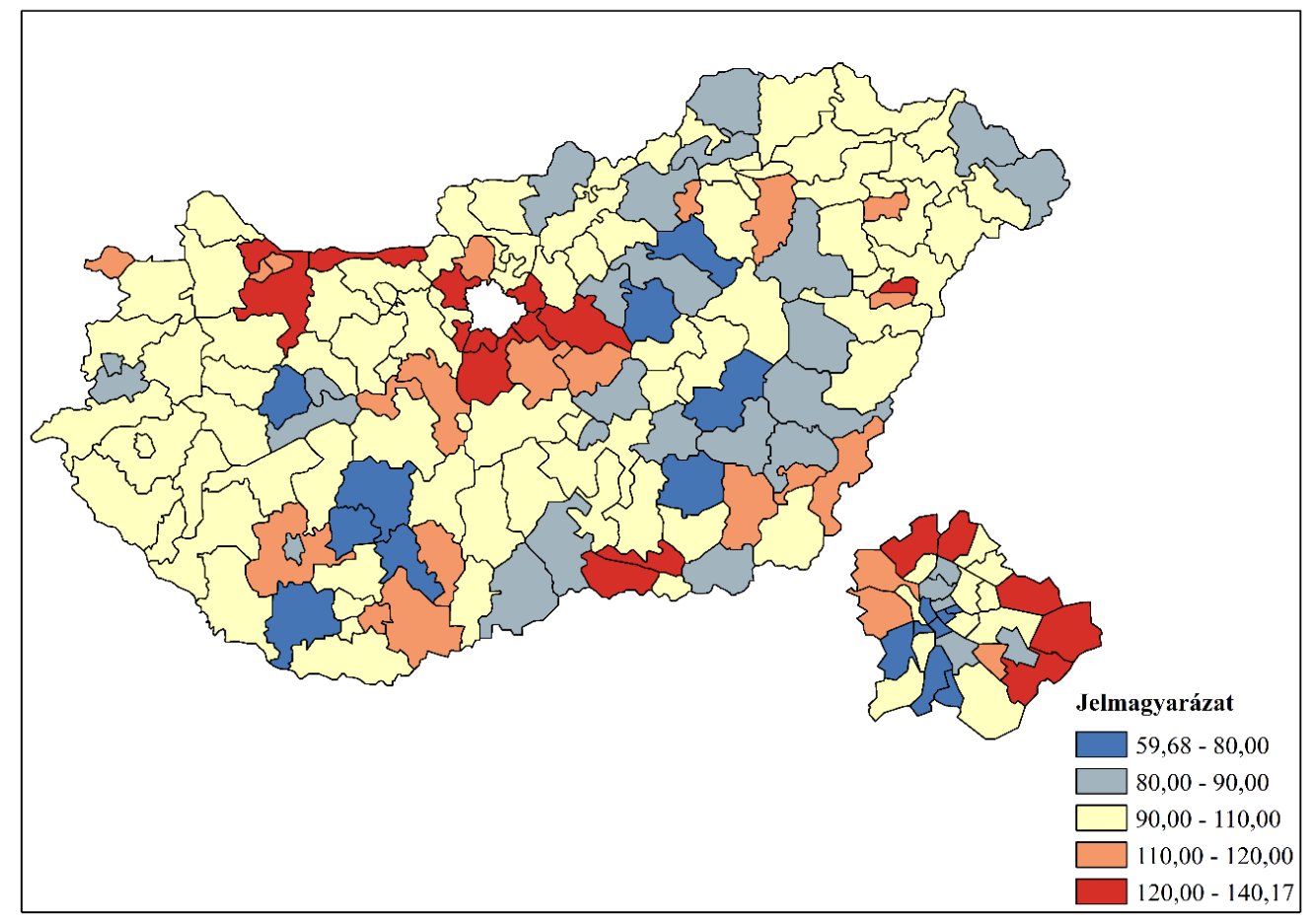

Forrás: Nemzeti Választási Iroda adatai alapján saját számítás és szerkesztés

2. melléklet: A választásra jogosultak százalékos aránya az országos átlaghoz viszonyítva a 176 egyéni választókerületben a 2006-os országgyülési választás alapján

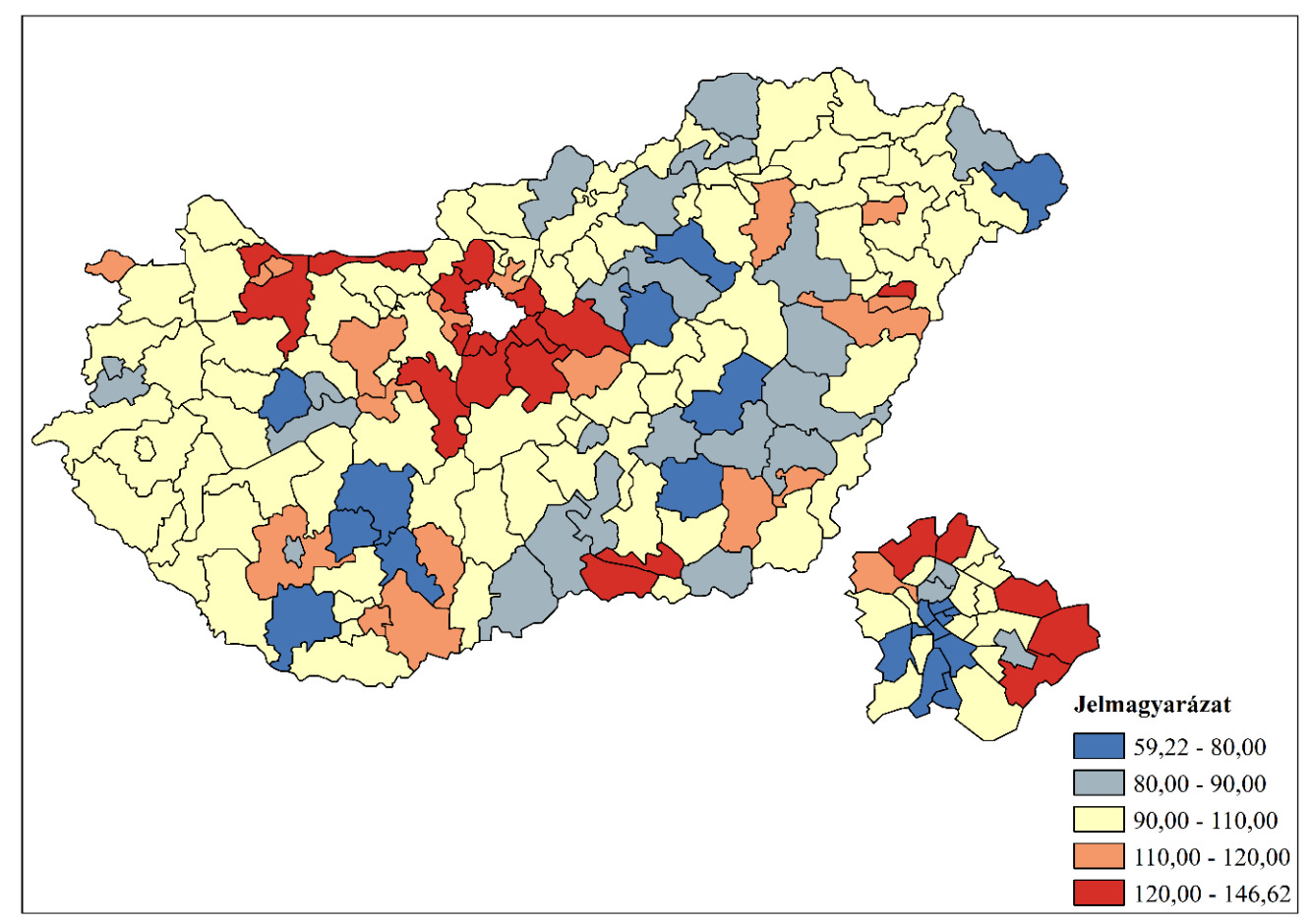

Forrás: Nemzeti Választási Iroda adatai alapján saját számítás és szerkesztés 
3. melléklet: A választásra jogosultak százalékos aránya az országos átlaghoz viszonyítva a 106 egyéni választókerületben a 2014-es országgyúlési választás alapján

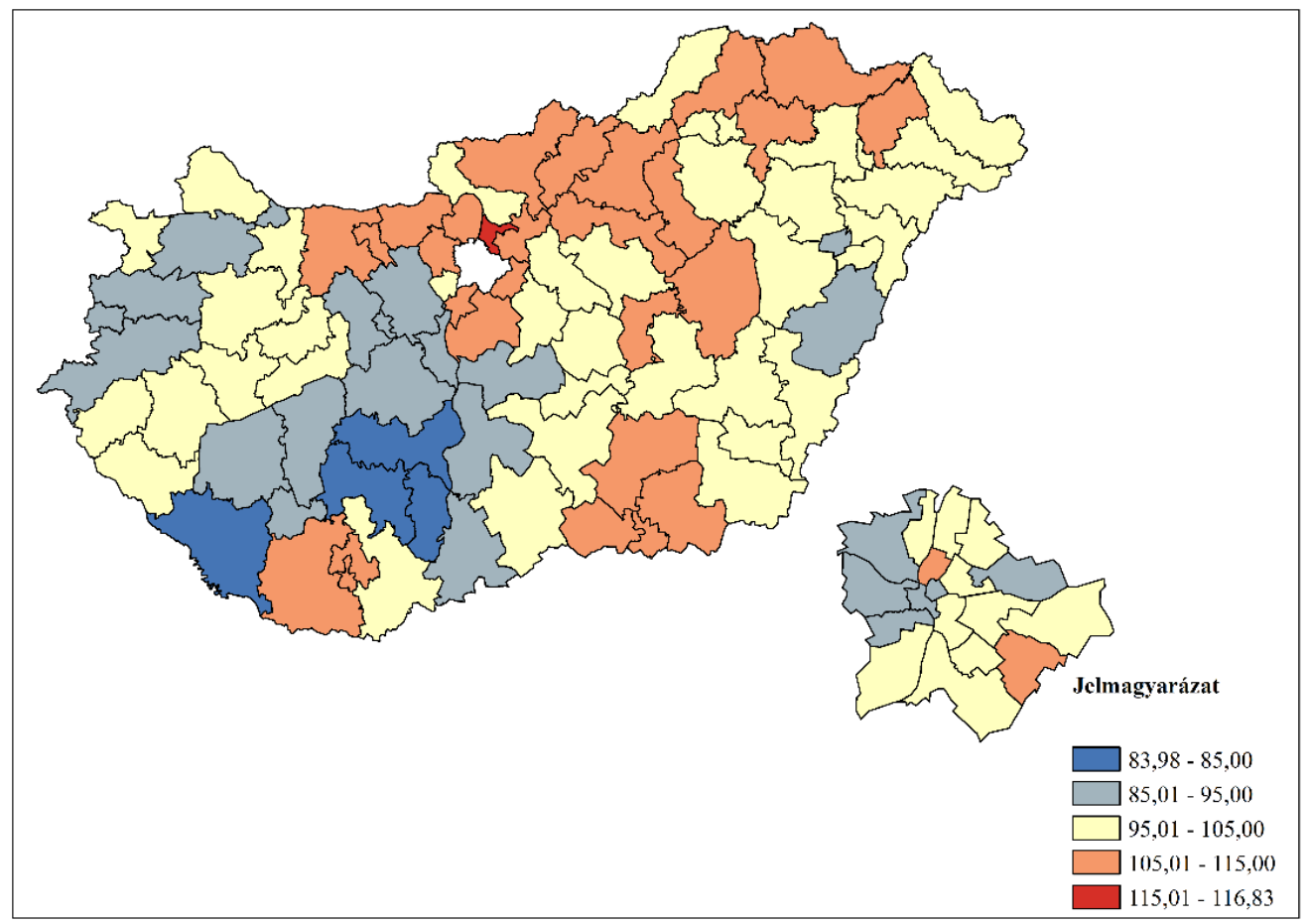

Forrás: Nemzeti Választási Iroda adatai alapján saját számítás és szerkesztés

\section{4. melléklet: Választási részvétel a 176 egyéni választókerületben a 2002-es országgyülési választás alapján}

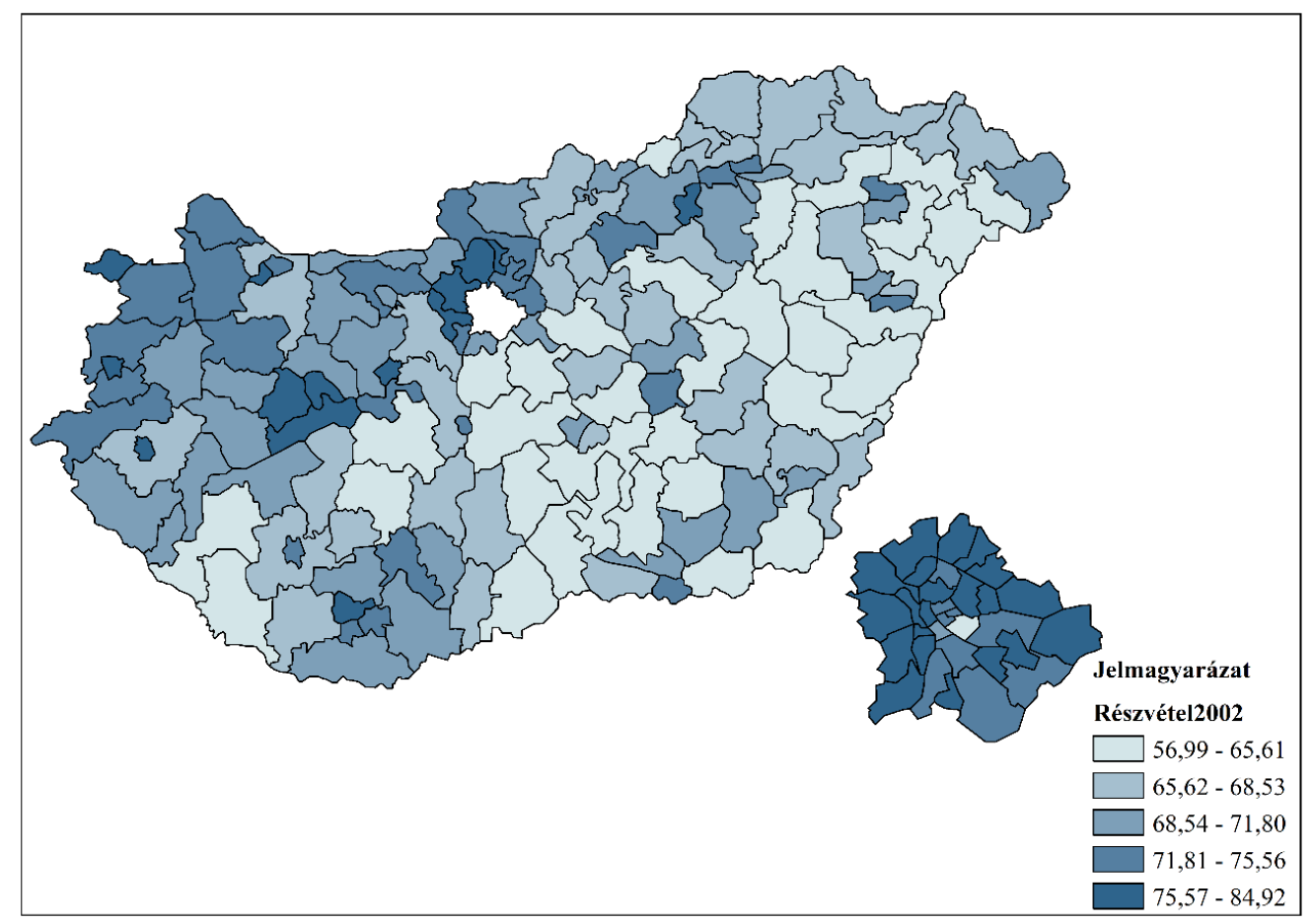

Forrás: Nemzeti Választási Iroda adatai alapján saját számítás és szerkesztés 
5. melléklet: Választási részvétel a 176 egyéni választókerületben a 2006-os országgyülési választás alapján

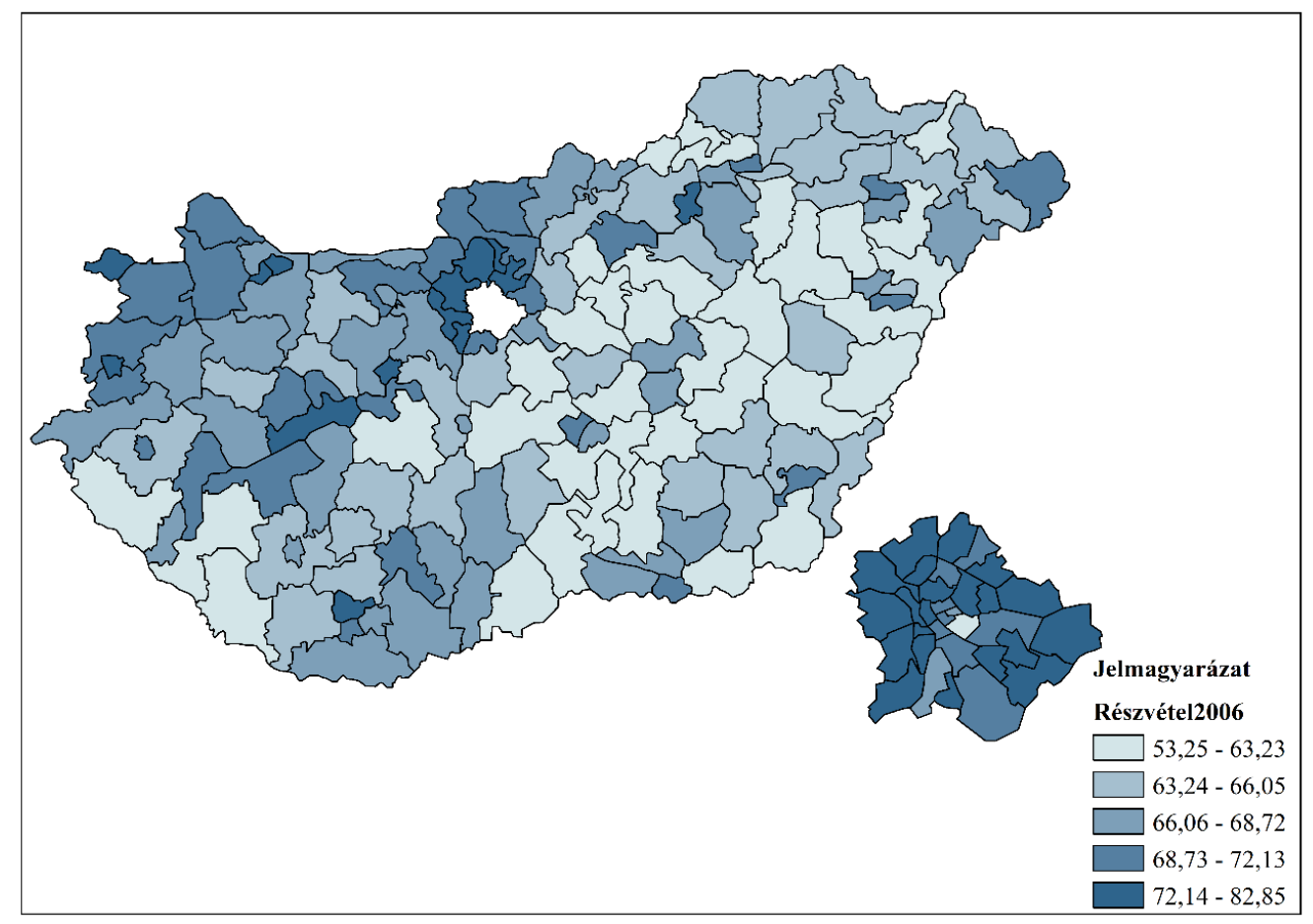

Forrás: Nemzeti Választási Iroda adatai alapján saját számítás és szerkesztés

6. melléklet: Választási részvétel a 176 egyéni választókerületben a 2010-es országgyúlési választás alapján

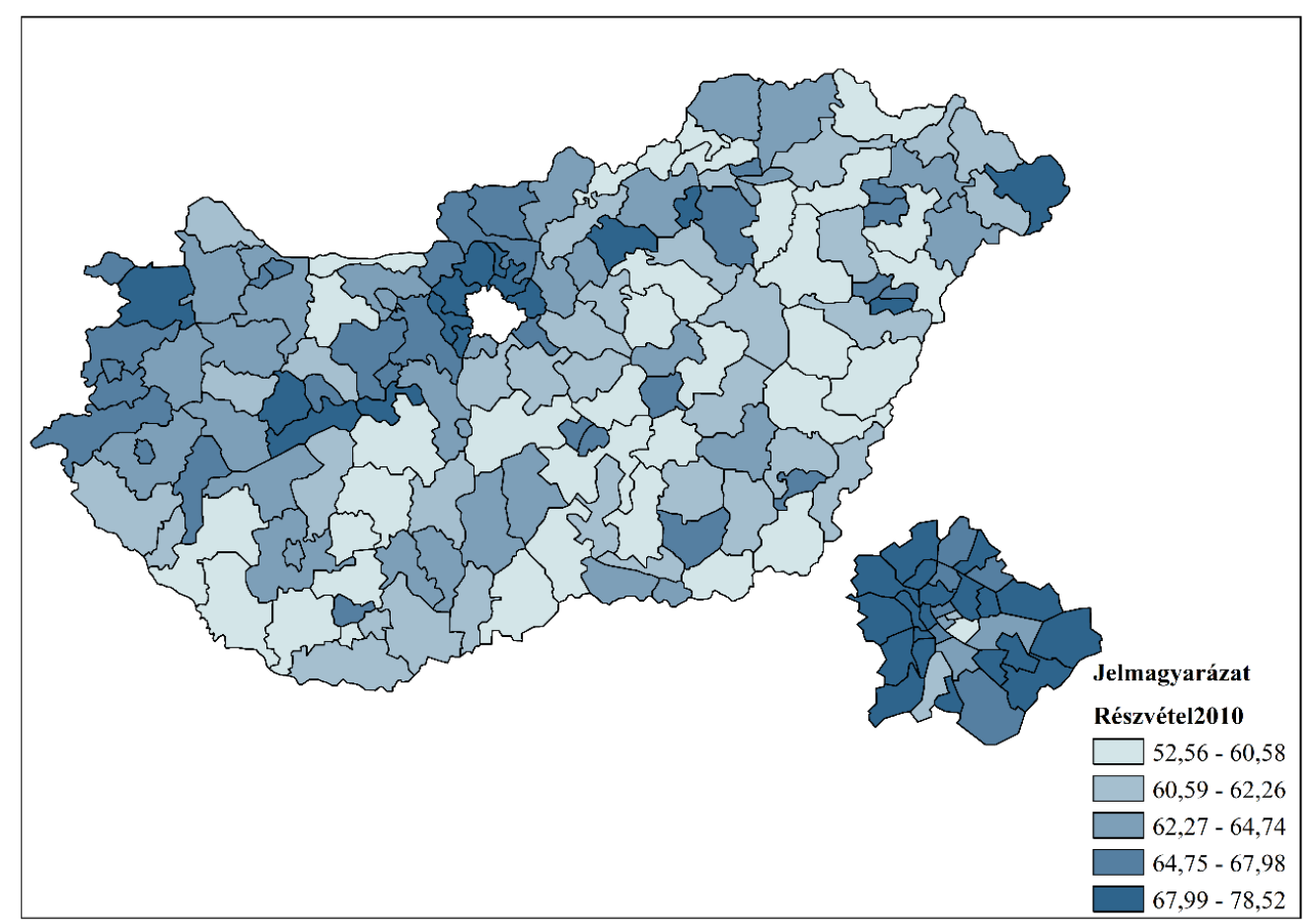

Forrás: Nemzeti Választási Iroda adatai alapján saját számítás és szerkesztés 
7. melléklet: Választási részvétel a 106 egyéni választókeruiletben a 2014-es országgyưlési választás alapján

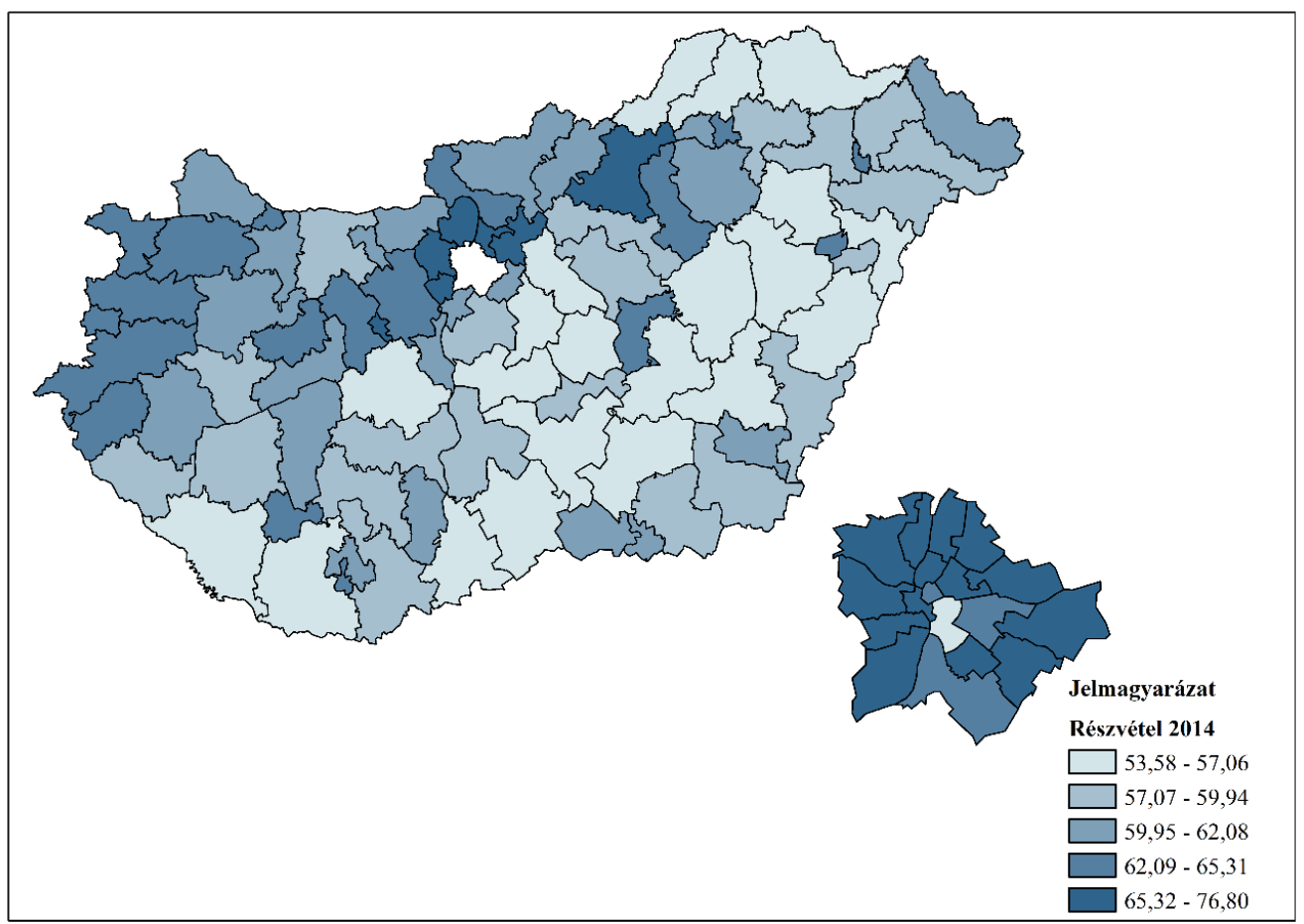

Forrás: Nemzeti Választási Iroda adatai alapján saját számítás és szerkesztés

8. melléklet: Választási részvétel a 106 egyéni választókerületben a 2018-as országgyúlési választás alapján

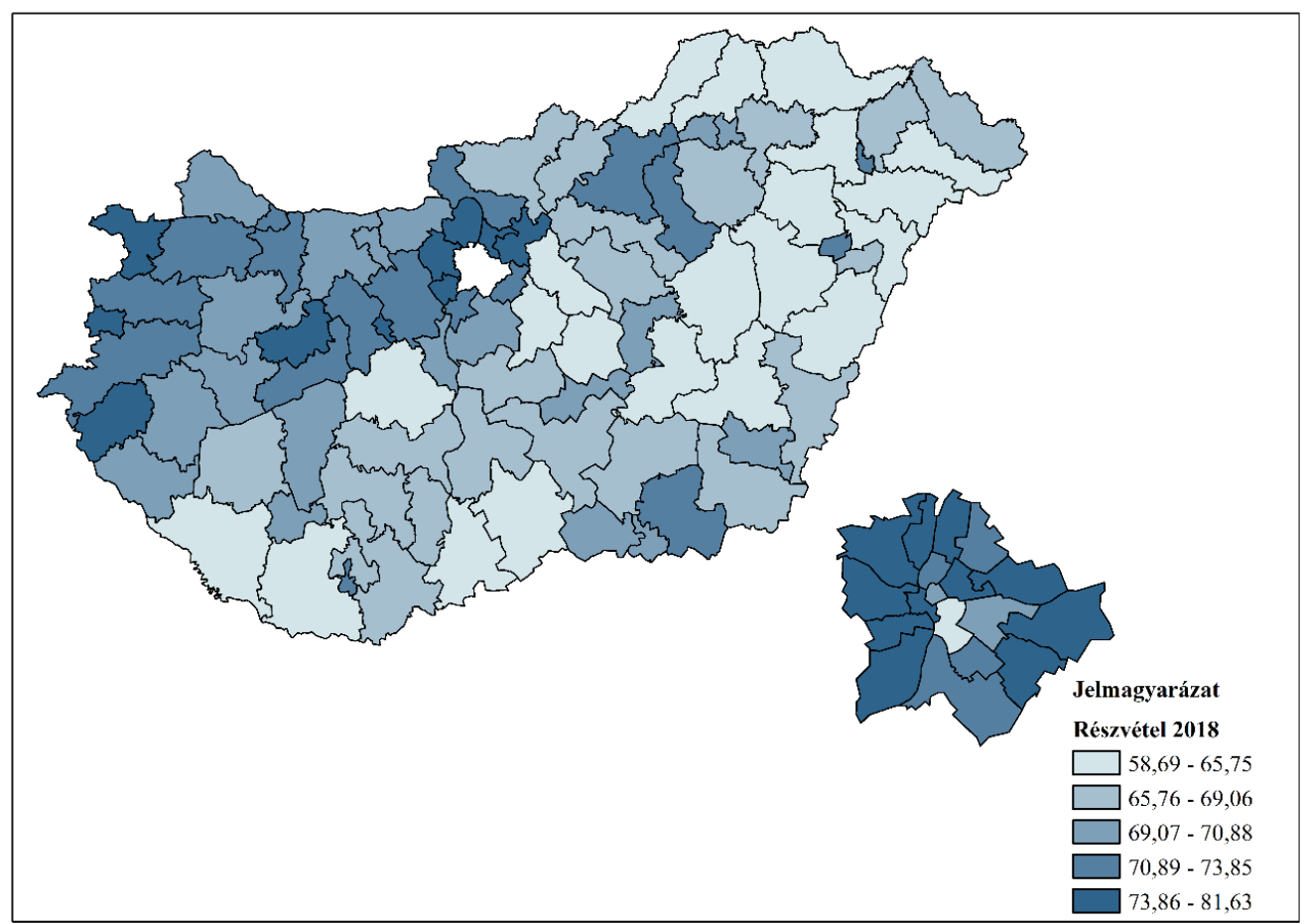

Forrás: Nemzeti Választási Iroda adatai alapján saját számítás és szerkesztés 
9. melléklet: Magyarország településinek választási részvétele a 2002-es országgyülési választás alapján

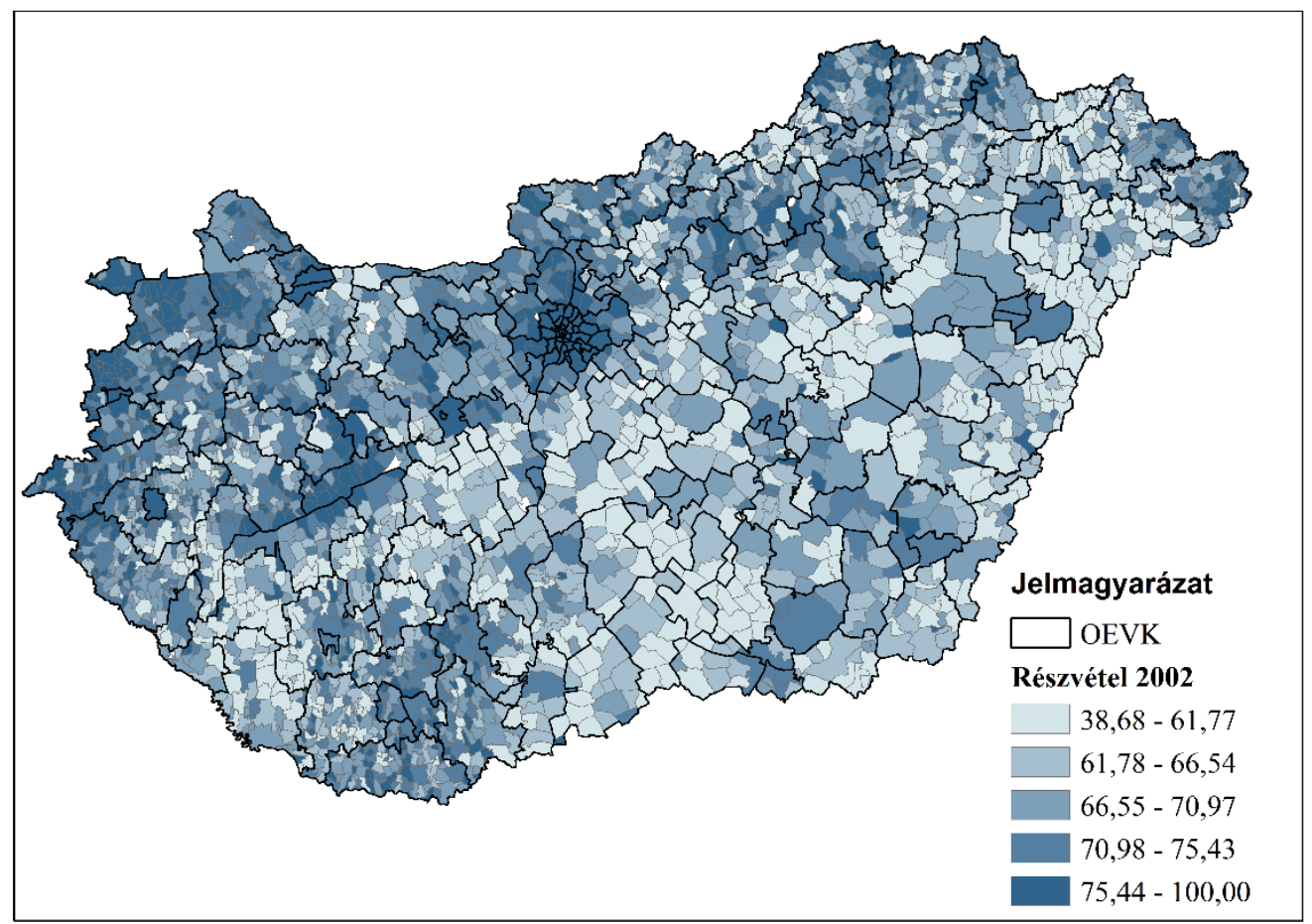

Forrás: Nemzeti Választási Iroda adatai alapján saját számítás és szerkesztés

10. melléklet: Magyarország településinek választási részvétele a 2006-os országgyülési választás alapján

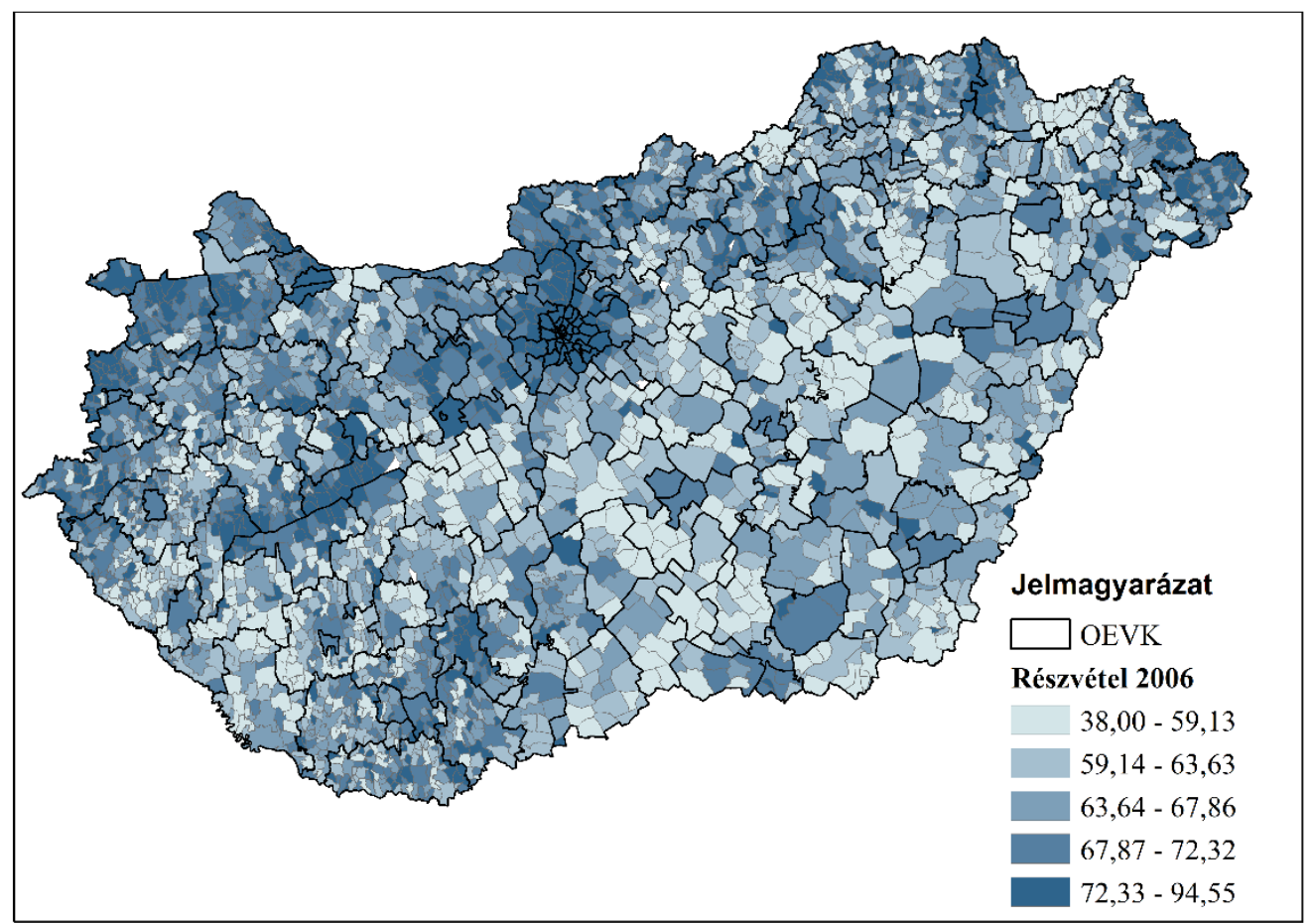

Forrás: Nemzeti Választási Iroda adatai alapján saját számítás és szerkesztés 
11. melléklet: Magyarország településinek választási részvétele a 2010-es országgyưlési választás alapján

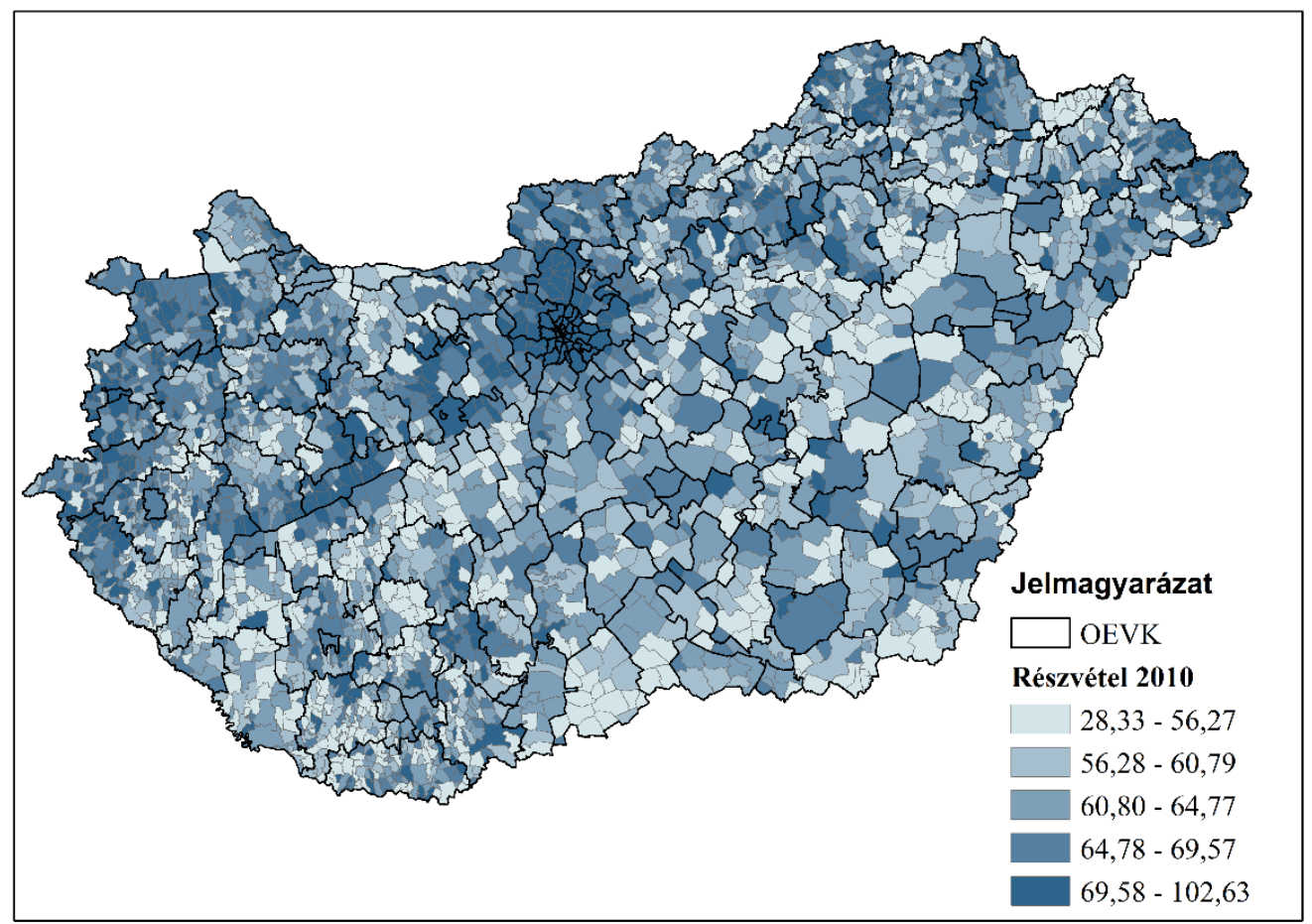

Forrás: Nemzeti Választási Iroda adatai alapján saját számítás és szerkesztés

12. melléklet: Magyarország településinek választási részvétele a 2014-es országgyưlési választás alapján

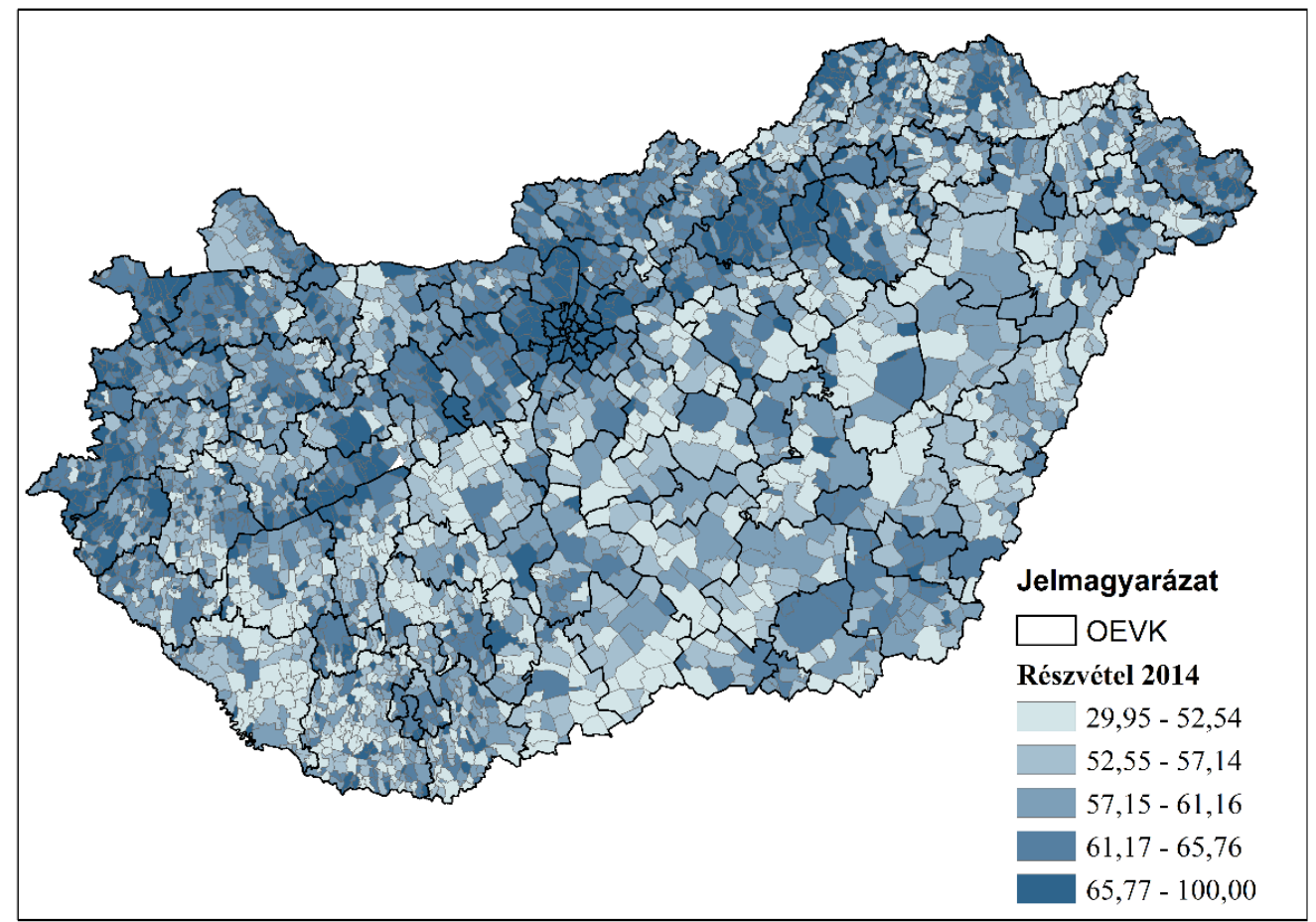

Forrás: Nemzeti Választási Iroda adatai alapján saját számítás és szerkesztés 
13. melléklet: Magyarország településinek választási részvétele a 2018-as országgyuulési választás alapján

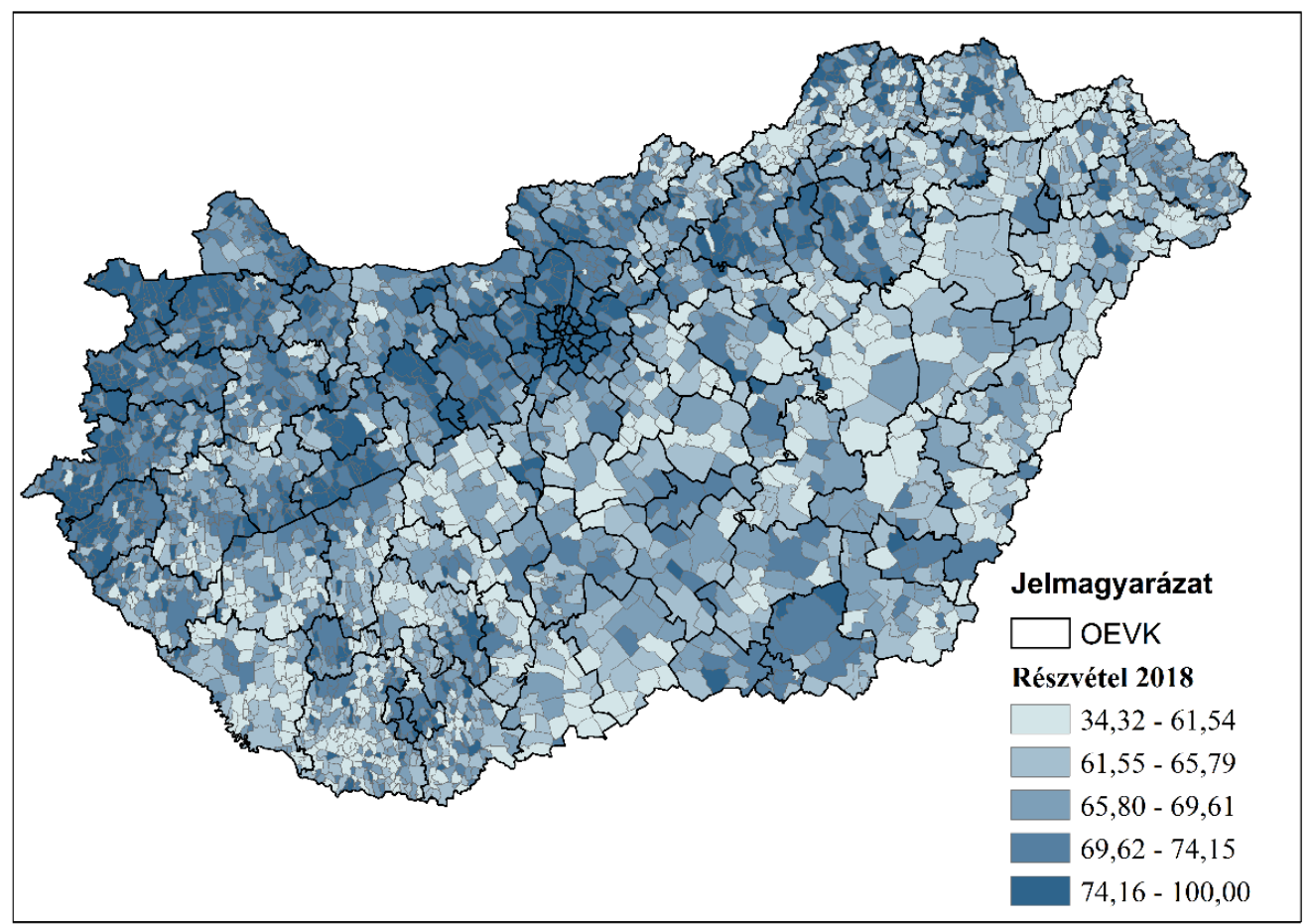

Forrás: Nemzeti Választási Iroda adatai alapján saját számítás és szerkesztés

14. melléklet A választási részvétel földrajzilag súlyozott regressziója települési szinten 2010 és 2018 között

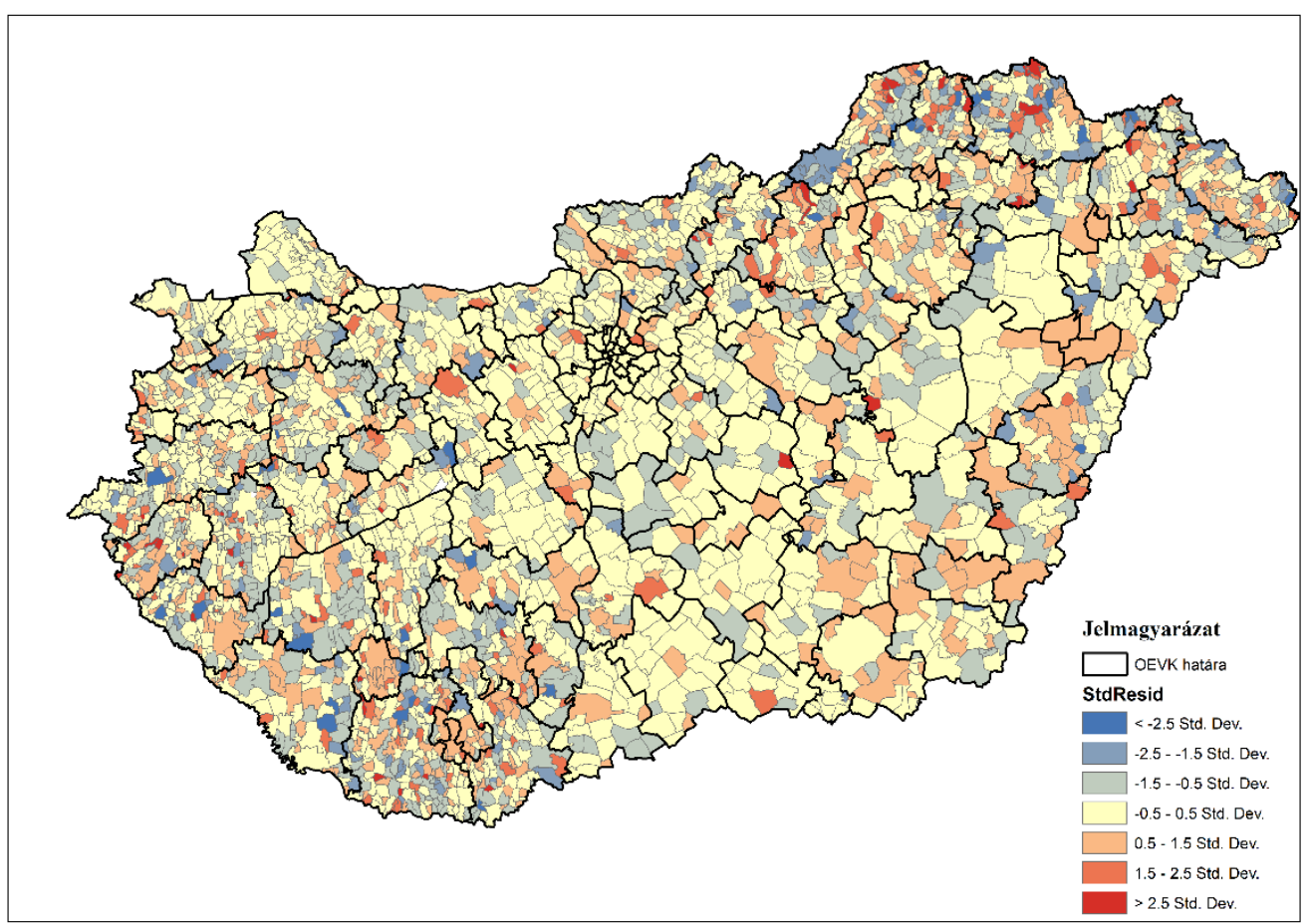

Forrás: Nemzeti Választási Iroda adatai alapján saját számítás és szerkesztés 
15. melléklet A választáson megjelent választópolgárok százalékos aránya az országos átlaghoz viszonyítva a 176 egyéni választókerületben a 2002-es országgyúlési választás alapján

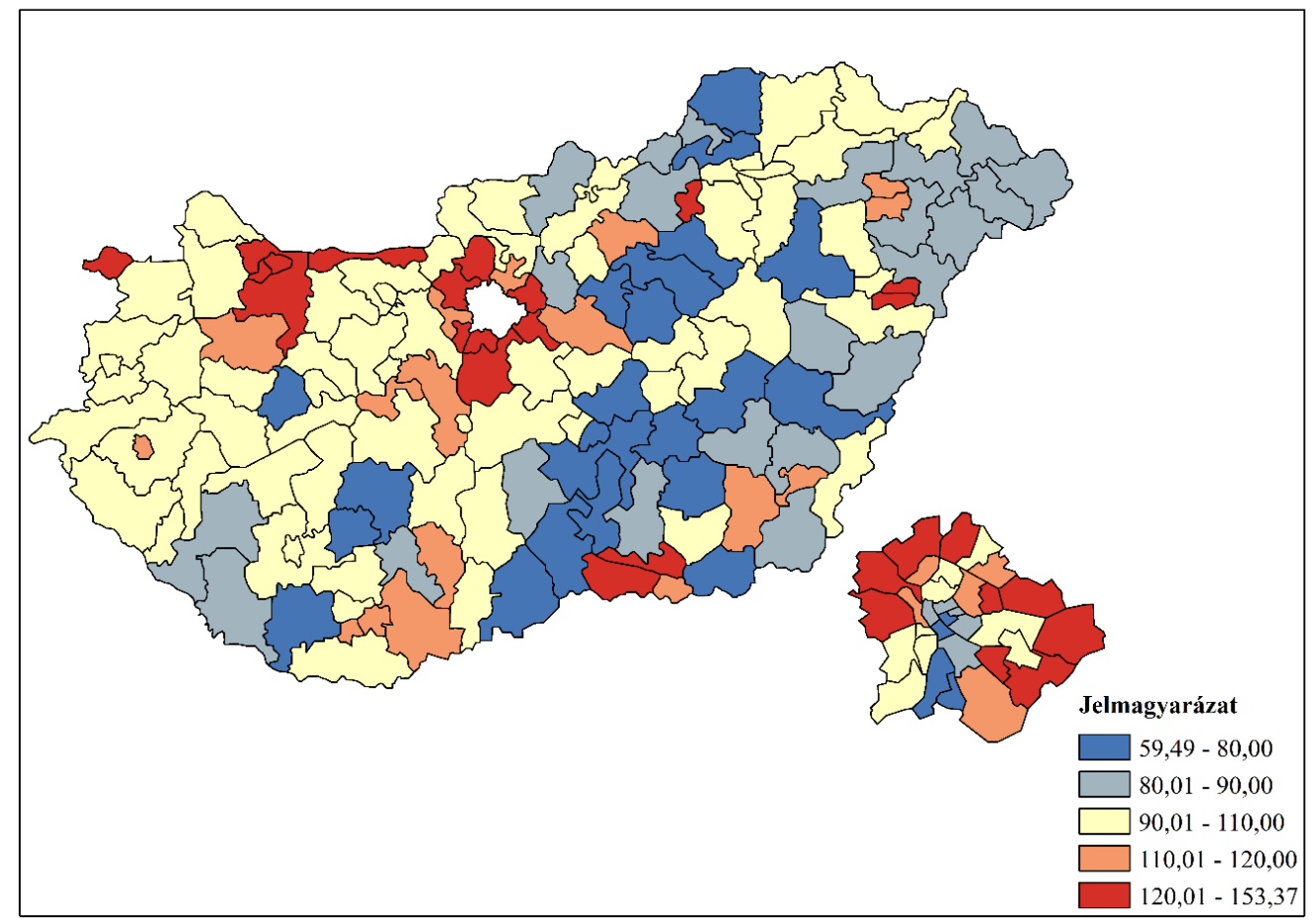

Forrás: Nemzeti Választási Iroda adatai alapján saját számítás és szerkesztés

16. melléklet A választáson megjelent választópolgárok százalékos aránya az országos átlaghoz viszonyítva a 176 egyéni választókerületben a 2006-os országgyúlési választás alapján

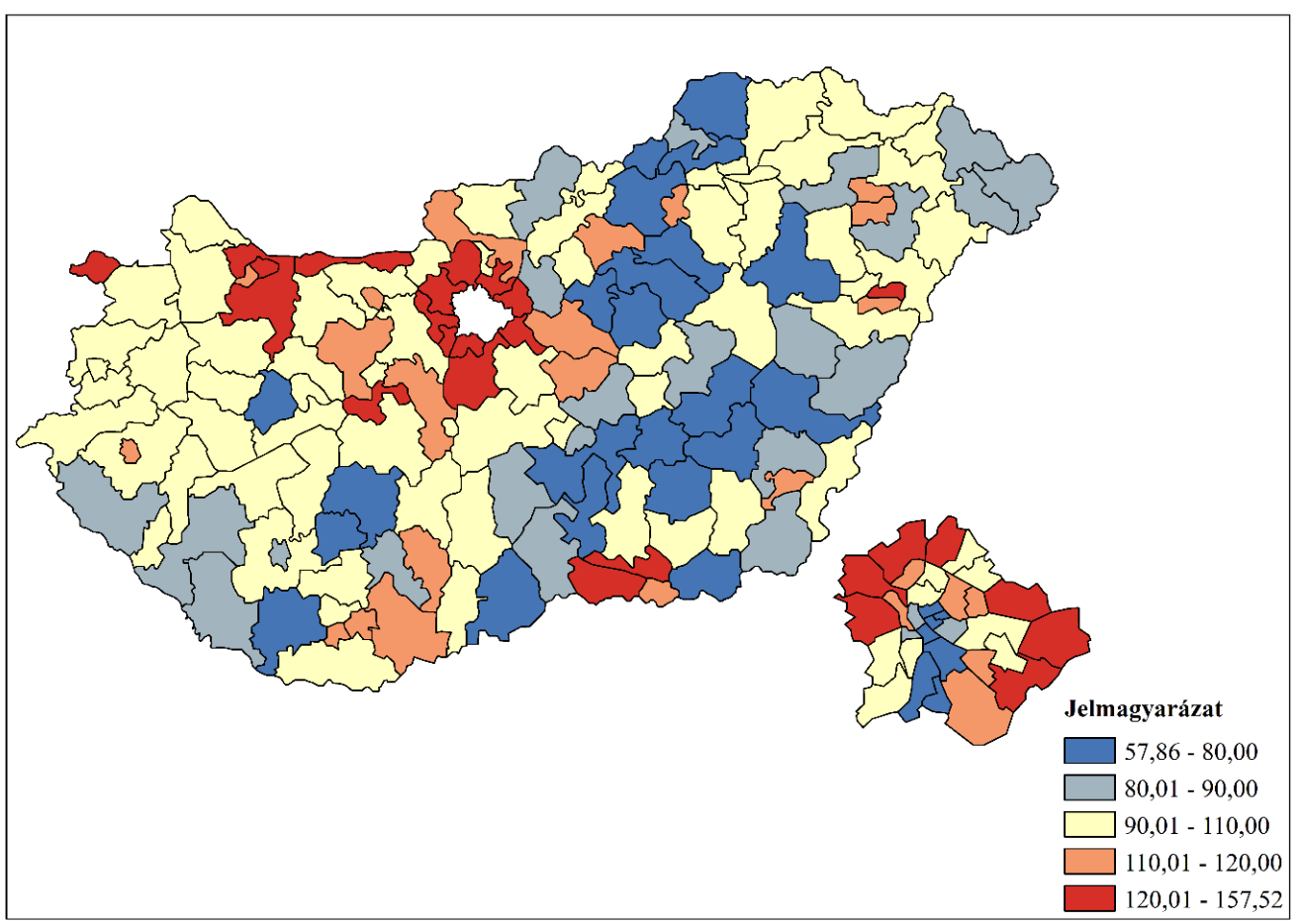

Forrás: Nemzeti Választási Iroda adatai alapján saját számítás és szerkesztés 
17. melléklet választáson megjelent választópolgárok százalékos aránya az országos átlaghoz viszonyítva a 176 egyéni választókerületben a 2010-es országgyülési választás alapján

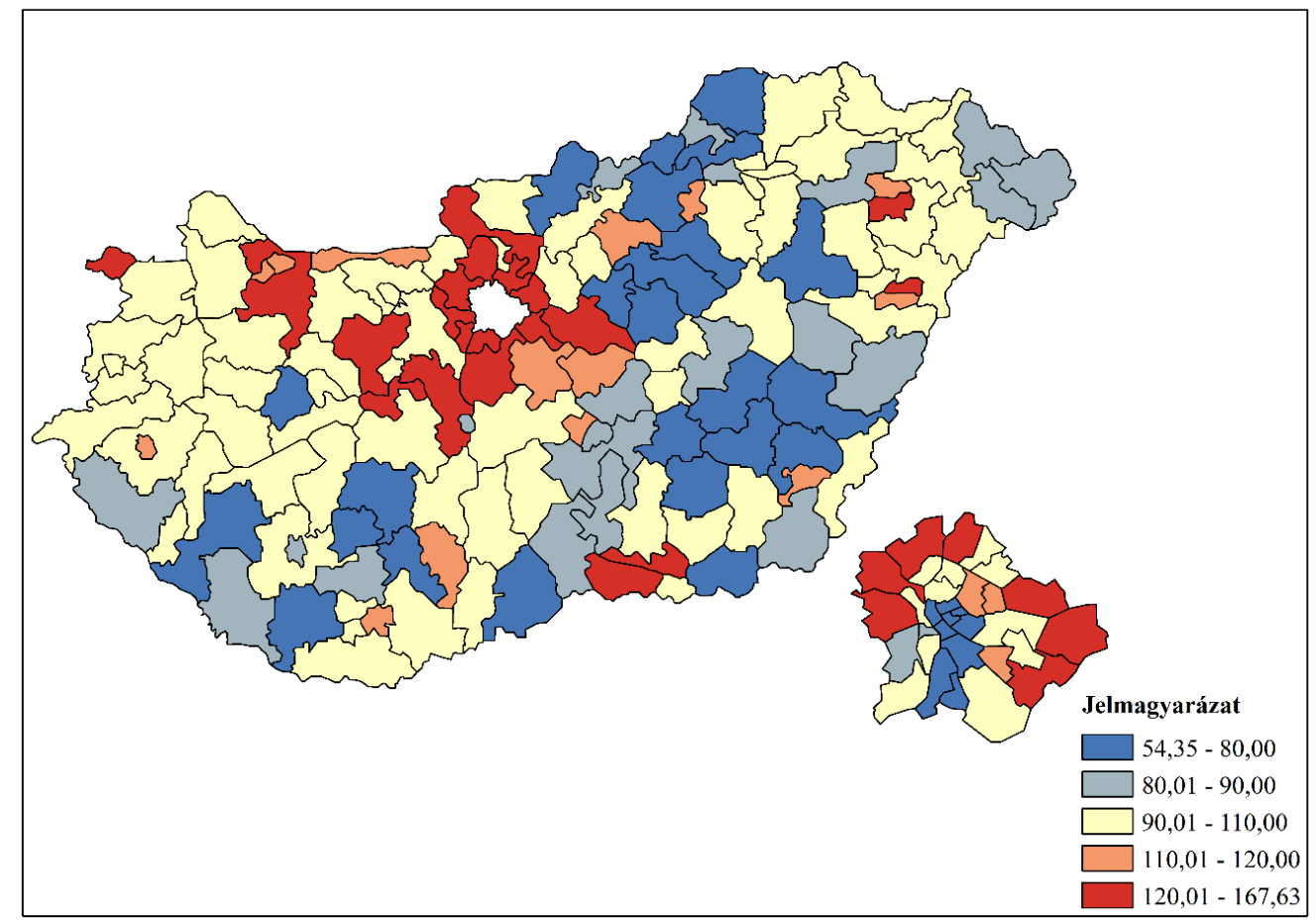

Forrás: Nemzeti Választási Iroda adatai alapján saját számítás és szerkesztés

18. melléklet A választáson megjelent választópolgárok százalékos aránya az országos átlaghoz viszonyítva a 106 egyéni választókerületben a 2014-es országgyülési választás alapján

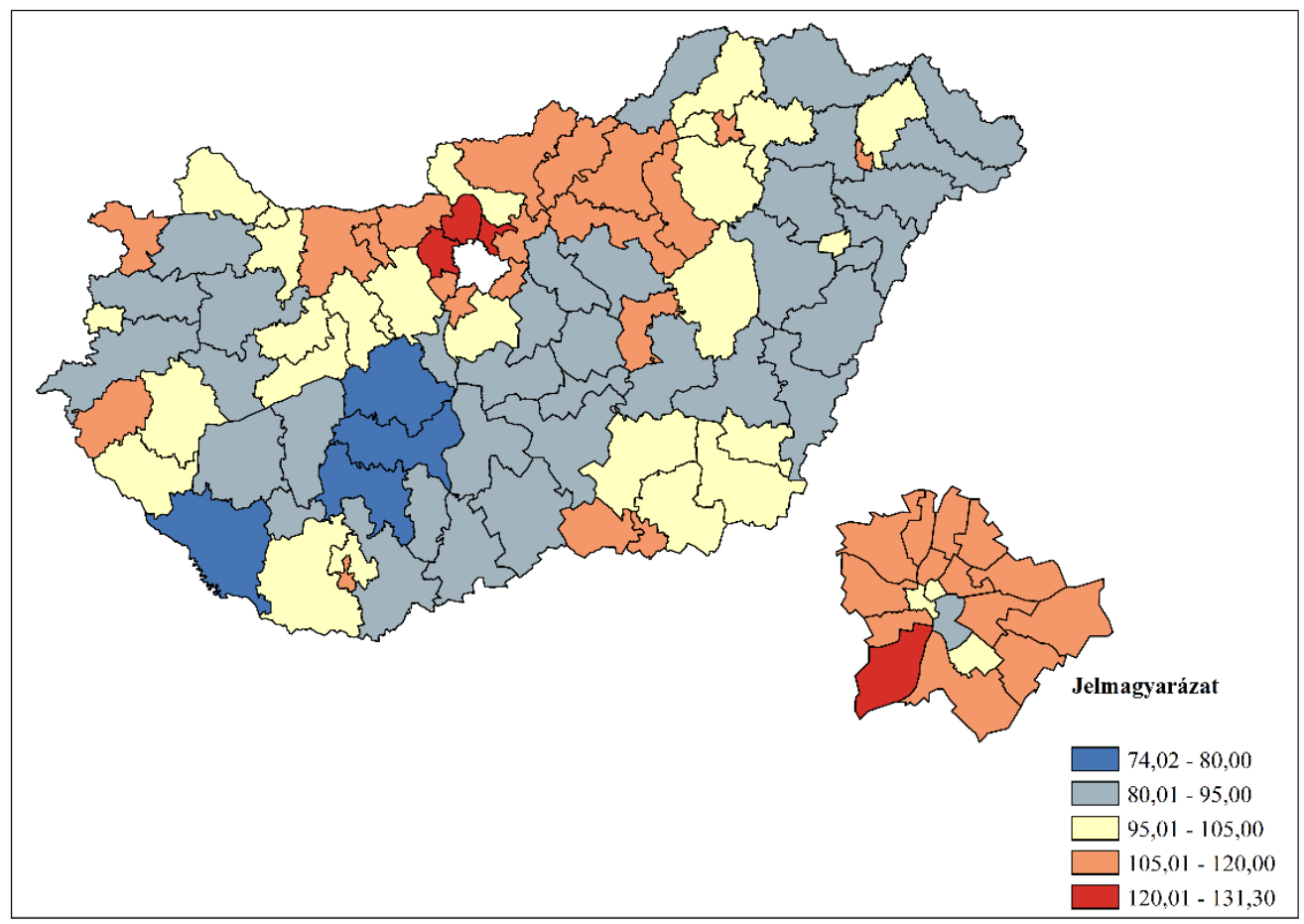

Forrás: Nemzeti Választási Iroda adatai alapján saját számítás és szerkesztés 
19. melléklet A választáson megjelent választópolgárok százalékos aránya az országos átlaghoz viszonyítva a 106 egyéni választókerületben a 2018-as országgyülési választás alapján

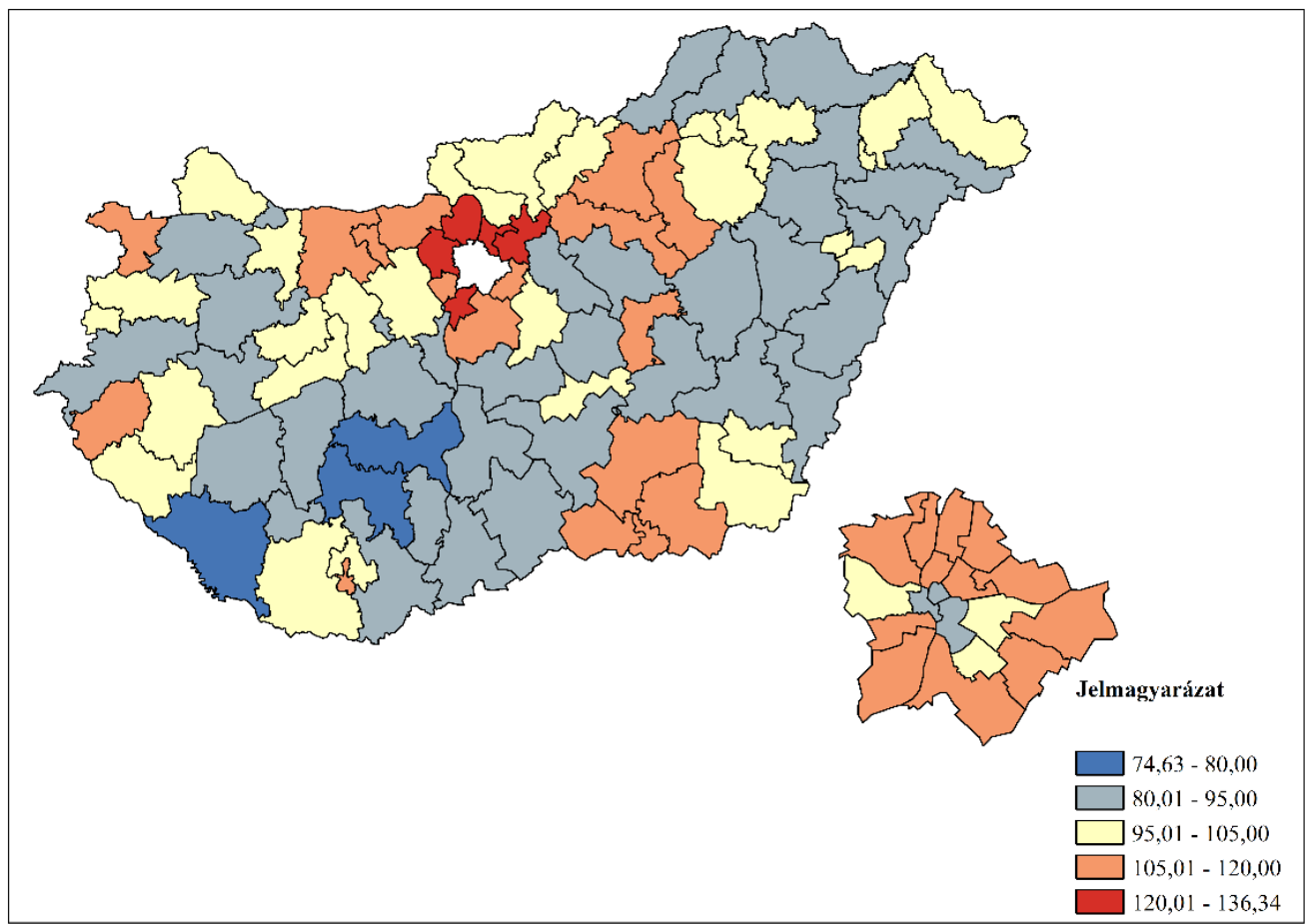

Forrás: Nemzeti Választási Iroda adatai alapján saját számítás és szerkesztés

20. melléklet A mandátumok kiosztásába kerülő listás voksok százalékos aránya az országos átlaghoz viszonyítva a 176 egyéni választókerületben a 2002-es országgyülési választás alapján

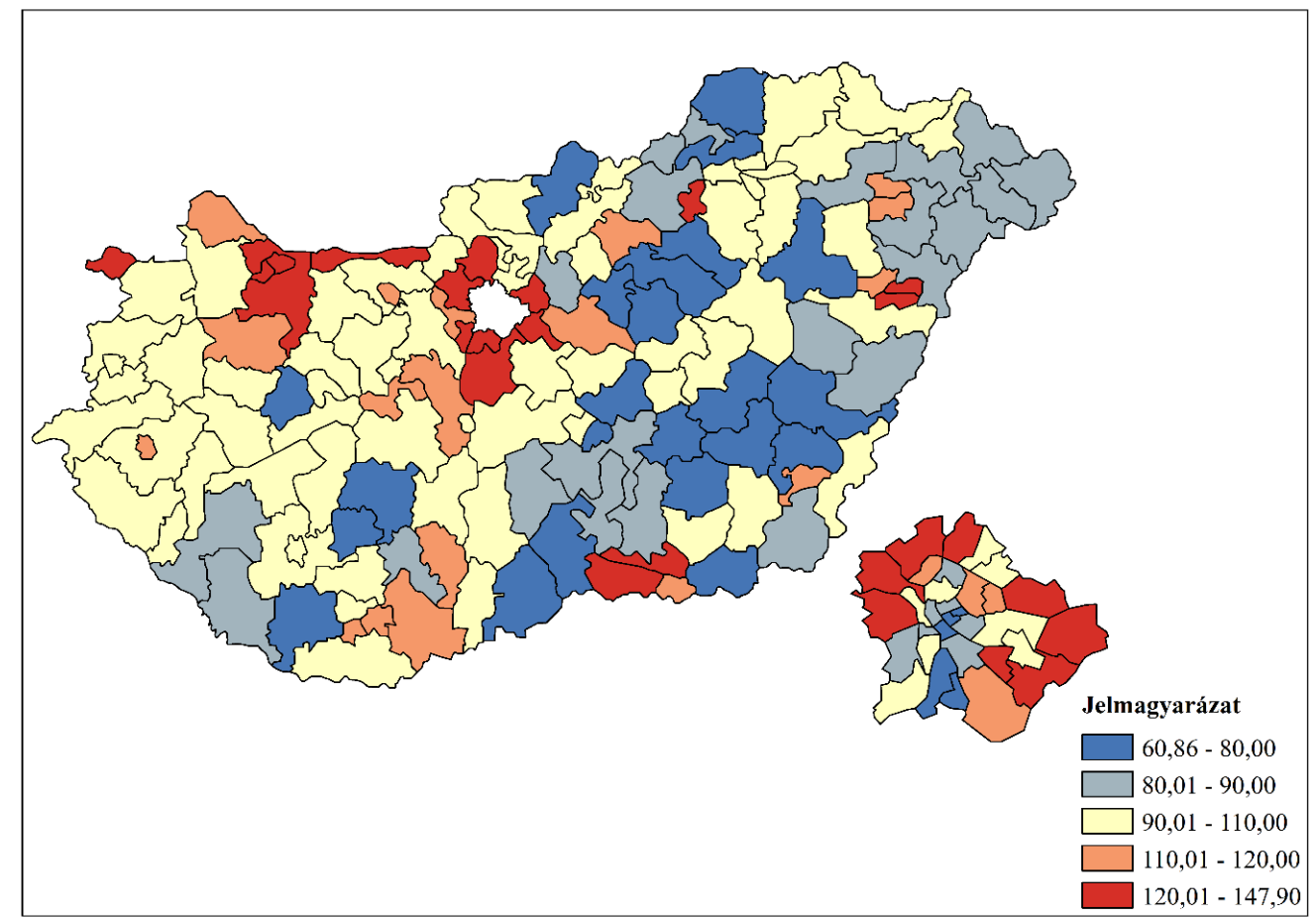

Forrás: Nemzeti Választási Iroda adatai alapján saját számítás és szerkesztés 
21. melléklet A mandátumok kiosztásába kerülö listás voksok százalékos aránya az országos átlaghoz viszonyítva a 176 egyéni választókerületben a 2006-os országgyülési választás alapján

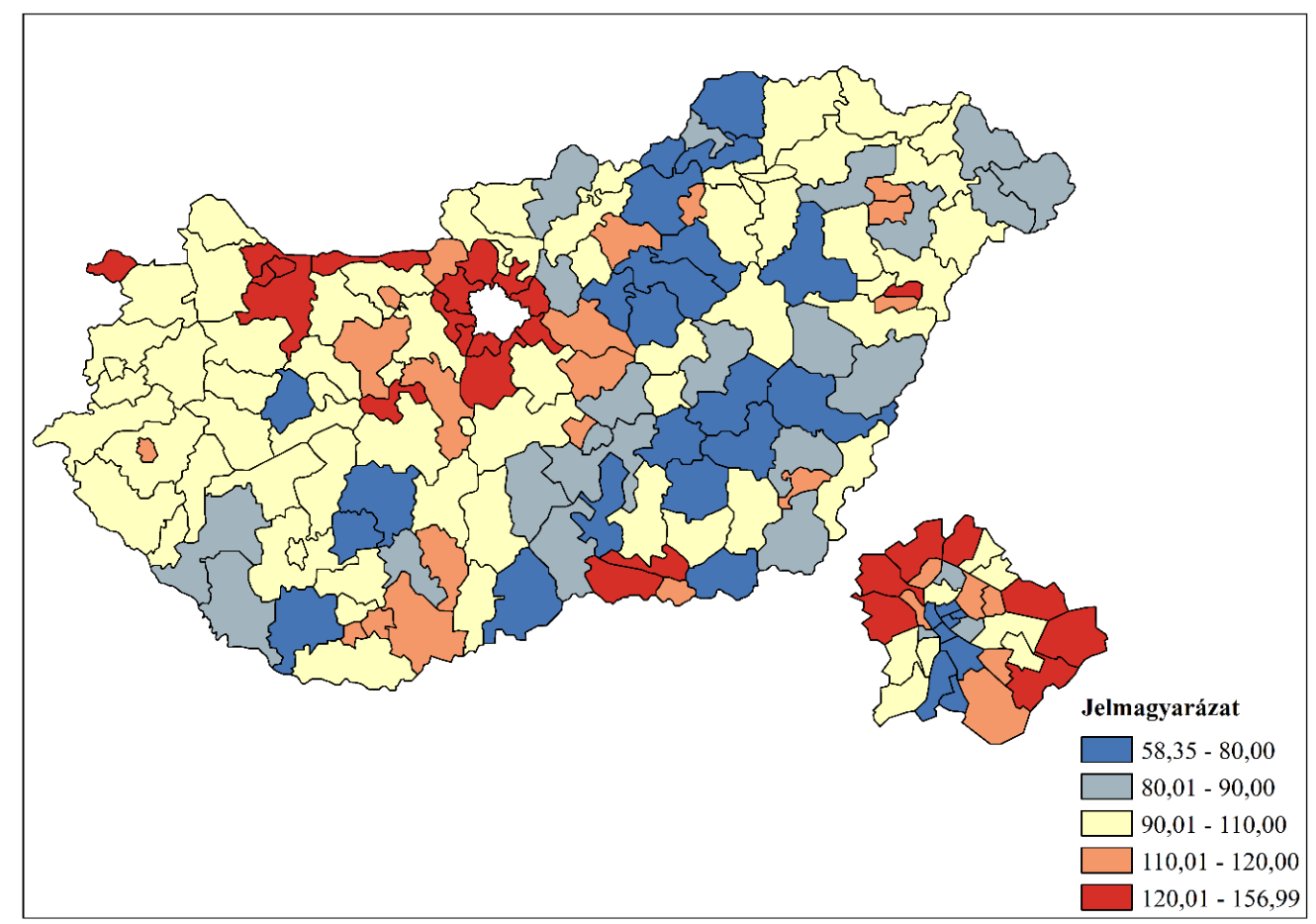

Forrás: Nemzeti Választási Iroda adatai alapján saját számítás és szerkesztés

22. melléklet A mandátumok kiosztásába kerülö listás voksok százalékos aránya az országos átlaghoz viszonyítva a 176 egyéni választókerületben a 2010-es országgyúlési választás alapján

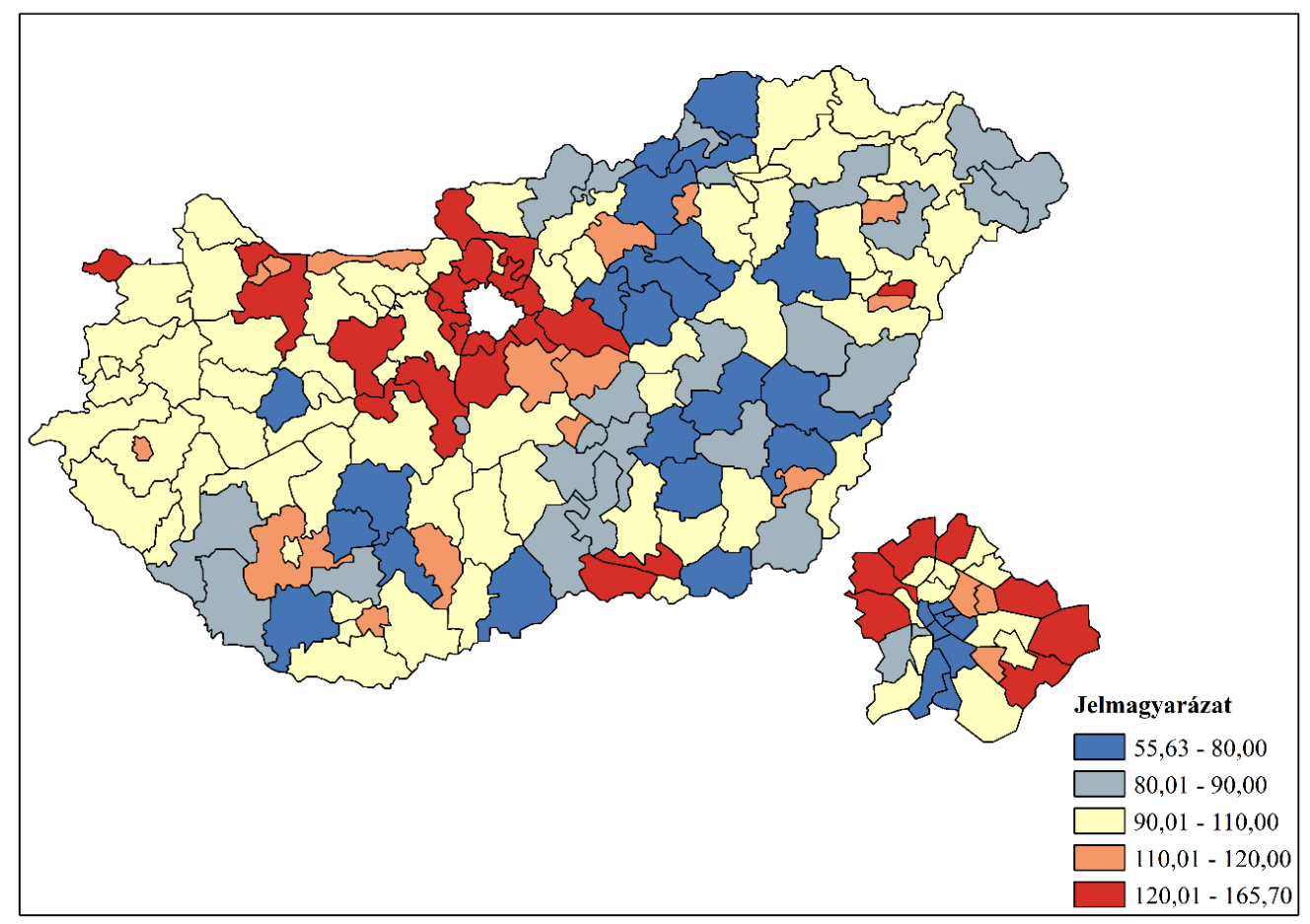

Forrás: Nemzeti Választási Iroda adatai alapján saját számítás és szerkesztés 
23. melléklet A mandátumok kiosztásába kerülö listás voksok százalékos aránya az országos átlaghoz viszonyítva a 106 egyéni választókerületben a 2014-es országgyuulési választás alapján

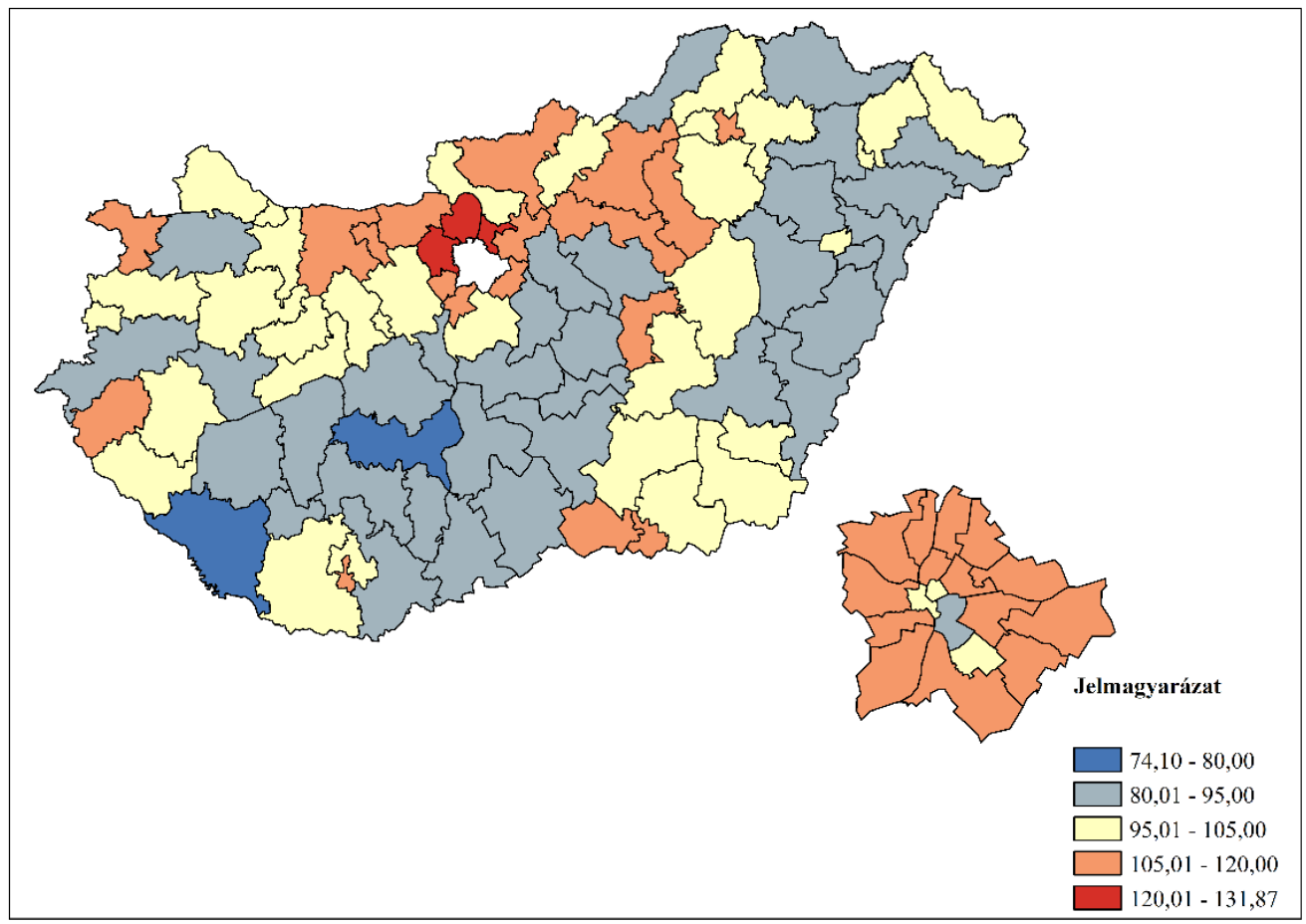

Forrás: Nemzeti Választási Iroda adatai alapján saját számítás és szerkesztés

24. melléklet A mandátumok kiosztásába kerülö listás voksok százalékos aránya az országos átlaghoz viszonyítva a 106 egyéni választókerületben a 2018-as országgyúlési választás alapján

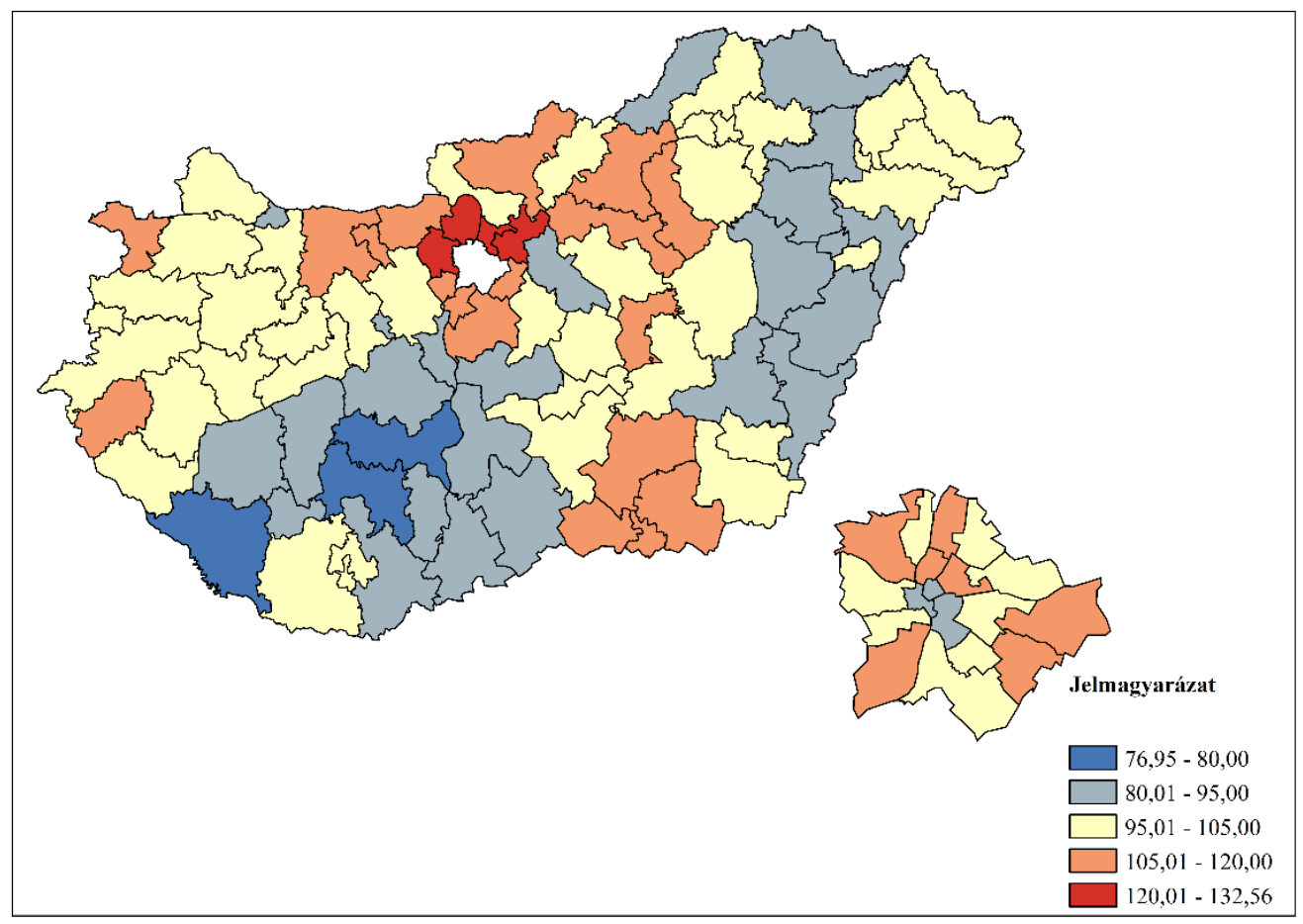

Forrás: Nemzeti Választási Iroda adatai alapján saját számítás és szerkesztés 